\title{
Systematics and evolutionary paleoecology of crinoids from the St. Louis Limestone (Mississippian, Meramecian) of the Illinois Basin
}

\author{
Lewis Anderson Cook \\ West Virginia University
}

Follow this and additional works at: https://researchrepository.wvu.edu/etd

\section{Recommended Citation}

Cook, Lewis Anderson, "Systematics and evolutionary paleoecology of crinoids from the St. Louis Limestone (Mississippian, Meramecian) of the Illinois Basin" (2010). Graduate Theses, Dissertations, and Problem Reports. 3083.

https://researchrepository.wvu.edu/etd/3083

This Dissertation is protected by copyright and/or related rights. It has been brought to you by the The Research Repository @ WVU with permission from the rights-holder(s). You are free to use this Dissertation in any way that is permitted by the copyright and related rights legislation that applies to your use. For other uses you must obtain permission from the rights-holder(s) directly, unless additional rights are indicated by a Creative Commons license in the record and/ or on the work itself. This Dissertation has been accepted for inclusion in WVU Graduate Theses, Dissertations, and Problem Reports collection by an authorized administrator of The Research Repository @ WVU.

For more information, please contact researchrepository@mail.wvu.edu. 


\title{
Systematics and Evolutionary Paleoecology of Crinoids from the St. Louis Limestone (Mississippian, Meramecian) of the Illinois Basin
}

\author{
Lewis Anderson Cook
}

\author{
Dissertation submitted to the \\ College of Arts and Sciences \\ at West Virginia University \\ in partial fulfillment of the requirements \\ for the degree of
Doctor of Philosophy
in
Geology

Thomas Kammer, Ph.D., Chair

William Ausich, Ph.D.

Richard Smosna, Ph.D.

Helen Lang, Ph.D.

Timothy Carr, Ph.D.

Department of Geology and Geography

Morgantown, West Virginia

2010 


\section{Abstract \\ Systematics and Evolutionary Paleoecology of Crinoids from the St. Louis Limestone (Mississippian, Meramecian) of the Illinois Basin}

\section{Lewis A. Cook}

Very little attention has been paid to crinoids of the St. Louis Limestone since the $19^{\text {th }}$ century. Now that the stratigraphic boundaries of the formation are well defined and a collection of crinoids specific to the St. Louis has become available, updated systematics and evolutionary paleoecology is possible.

Previous work recognized a significant transition in the macroevolution of crinoids that occurred during the Mississippian Period. The diversity of crinoid taxa changed substantially from faunas dominated by camerates and primitive cladids to those dominated by advanced cladids. Much of that change took place during the Meramecian Stage, which includes the St. Louis Limestone. The preceding Salem Limestone contained a prevalence of camerates whereas the following superjacent Ste. Genevieve Limestone contained a more advanced cladids. Questions that are considered include: what changes in morphology of crinoids accompanied that transition; what, if any, environmental change occurred that influenced the major transition in crinoids; and what was the precise change in the distribution of crinoid taxa throughout the deposition of the St. Louis Limestone? The approach to providing a plausible description and explanation includes an evaluation of the geologic setting, a re-evaluation of crinoid systematics, and an investigation of the evolutionary paleoecology of the St. Louis Limestone crinoids.

Lithology of the St. Louis Limestone is compared to the Salem Limestone below and the Ste. Genevieve limestone above. A change in environment occurred within the St. Louis. The Salem and Ste. Genevieve were deposited in a deeper water setting, whereas St. Louis deposition took place in a low-energy, mostly lagoonal setting. This is reflected in microscopic study by the prevalence of mudstone and wackestone in the St. Louis while ths Salem and St. Genevieve are granistones

Systematic evaluation confirmations 17 species of crinoids previously assigned to the St. Louis. Three crinoid species that were identified within other formations, but not in the St. Louis, were added. One new species, Armenocrinus howelli was identified. Three species were synonymized within the St. Louis. Eight species previously listed as belonging to the St. Louis were found to be incorrectly assigned.

Crinoids had been adapting in their overall morphology prior to the Meramecian. Various changes in feeding structures, predatory defenses and mobility occurred from the Ordovician through the early Meramecian. Those adaptations allowed crinoids with the most advantageous morphology to survive adverse environmental conditions. In fact, two events took place during the Meramecian that would have impacted the survival of crinoids. Durophagous predators increased in numbers and a prolonged regression reduced habitat area during the deposition of the St. Louis. Those two factors impacted crinoids in a negative way. That evolutionary bottleneck resulted in the better adapted advanced cladids radiating, whereas the previously dominant camerates saw a substantial decrease in diversity. 


\section{Dedication}

I dedicate this work to my wonderful wife, Vicki, whose unfailing support and sacrifice is beyond commonplace in today's world.

I also dedicate this work to the the people of the Town of Fayetteville, West Virginia who allowed me to become a part of their community and provided the means over my years in medical practice there that allowed me to attempt this endeavour. 


\section{Acknowledgements}

As with any work such as this dissertation, there are those whose assistance along the way has been invaluable in my being able to complete this project. Peggy Fisherkeller, Curator of Geology, Indiana State Museum, and Jann Thompson, Deputy Chair and Collections Manager, National Museum of Natural History, were very accommodating in allowing my visits and work at their museums. Robert Howell collected the specimens of crinoids from the Harris Stone Quarry, Bainbridge, Indiana, and also spent an entire day guiding Dr. Kammer and me through the site. His collection was an integral part of this work, without which it would have been impossible.

I very much appreciate assistance from the Department of Geology and Geography in providing financial assistance in the form of tuition waviers and travel expenses as well creating a very nice facility and faculty that was very nurturing.

My dissertation committee, including Dr. Richard Smosna, Dr. Helen Lang, Dr. Timothy Carr, Dr. William Ausich and my advisor Dr. Thomas Kammer have been unfailing in their attention to the steps in preparing this work. I want to thank Dr. Ausich, in particular, the outside committee member and having to travel a long distance to attend my proposal and defense, for his kindness.

My advisor, Dr. Thomas Kammer with his extraordinary abilities as a scientist and a writer insisted on the best work that I was able to achieve. Anything about this work that is of any value is to his credit. 


\section{Table of Contents}

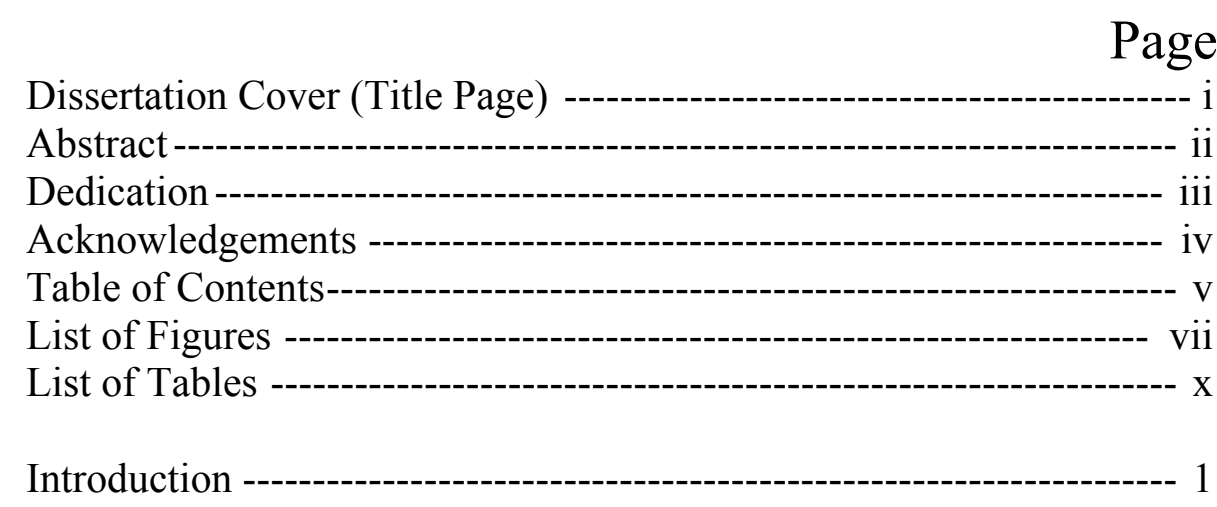

Geologic Setting

Introduction----------------------------------------------------------- 3

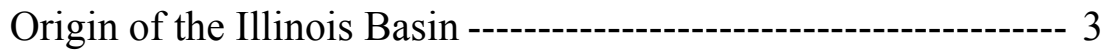

Mississippian and Meramecian Stratotypes ------------------------ 9

Formations within study area:

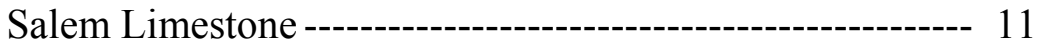

St. Louis Limestone------------------------------------------ 16

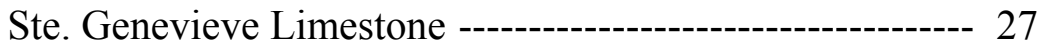

Thickness and Extent of formations

within the study area------------------------------------ 35

Summary--------------------------------------------------------------- 38

Systematics

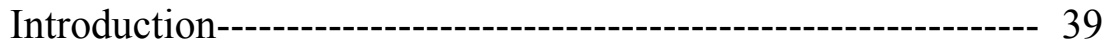

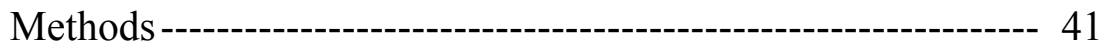

Faunal Analysis ----------------------------------------------------- 44

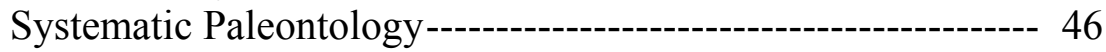

Evolutionary Paleoecology

Introduction-----------------------------------------------------------101

History of Crinoid Subclass Distribution-------------------------101

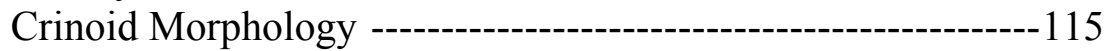

Adaptation ----------------------------------------------------------122

Environmental Change during the Meramecian -----------------134

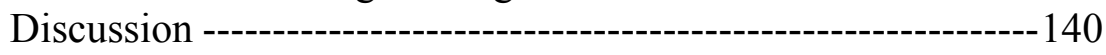

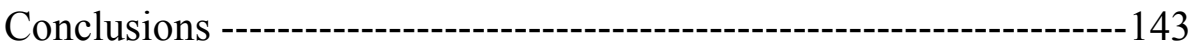

References --------------------------------------------------------------------------149

Appendix A. Key for figures 5, 7, and 11, of Geologic

Setting section, and Appendix B----------------------------------- 173 
Appendix B. Stratigraphic column of Salem, St. Louis and

Ste. Genevieve limestone at the Casper Stolle Quarry-----------174

Appendix C. Stratigraphic column of the Salem, St. Louis and

Ste. Genevieve limestones, Owen County, Indiana ------------- 175

Appendix D. Indiana State Museum Crinoid Collection

from Harris Stone Quarry, Bainbridge, Indiana.------------------ 176

Appendix E. Studied crinoids from the United States

National Museum, Springer Collection.------------------------------ 177

Appendix F. Crinoids from the Field Museum of

Natural History, Chicago, Illinois.-------------------------------- 179

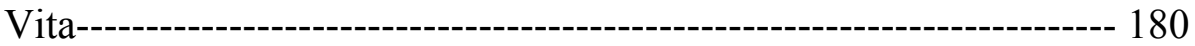




\section{List of Figures}

Page

Figure 1. Map of north central United States showing major basins, arches and domes.------- 4

Figure 2. Geologic cross-section of the Illinois Basin below the Zuni and Tejas Sequences.-- 6

Figure 3. North-south cross section of the Illinois Basin. Note the Salem, St. Louis and Ste.

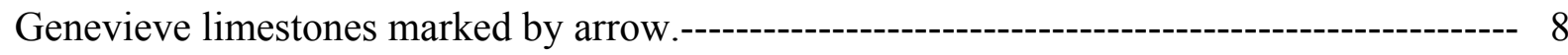

Figure 4. Correlation of stratigraphic units across Illinois, Indiana and Missouri.---------------- 9

Figure 5. Stratigraphy column of Salem Limestone and upper Warsaw Formation,

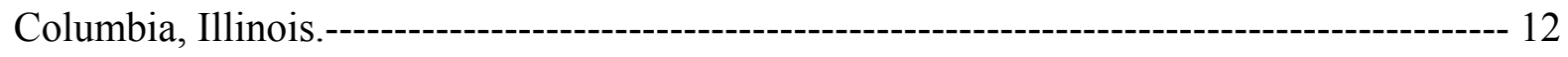

Figure 6. Salem Limestone photomicrographs.------------------------------------------------------- 14

Figure 7. Stratigraphy column, St. Louis Limestone at Alby Quarry, Alton, Illinois.----------- 19

Figure 8. Chert nodules in upper layers of St. Louis Limestone, Harris Stone Quarry,

Bainbridge, Indiana.

Figure 9. Collapse breccias, St. Louis Limestone, Harris Stone Quarry, Bainbridge, Indiana. 21

Figure 10. Stratigraphic column, Harris Stone Quarry, Bainbridge, Indiana.--------------------- 22

Figure 11. St. Louis Limestone photomicrographs from Harris Stone Quarry, Putnam County,

Indiana. $-23,24$

Figure 12. Stratigraphic column of the Ste. Genevieve Limestone, Casper Stolle Quarry, Alton, Illinois. 28

Figure 13. Ste. Genevieve Limestone photomicrograph. $-30,31$

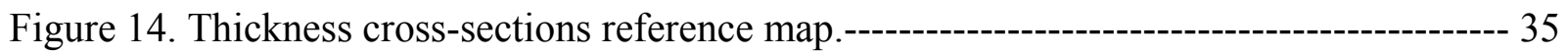

Figure 15. East-west thickness of the Salem, St. Louis and Ste. Genevieve Limestone formations from Alton, Illinois, to the Harris Stone Quarry, Bainbridge, Indiana. 36 
Figure 16. North-south thickness of the Salem, St. Louis and Ste. Genevieve Limestone formations from Perry County to the Harris Stone Quarry, Bainbridge, Indiana.-------------- 37

Figure 17. The Illinois Basin, Alton, Illinois, to the west and Bainbridge,

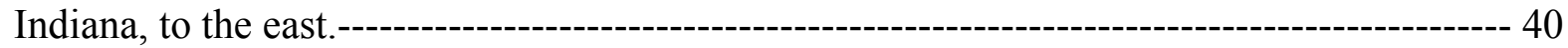

Figure 18. The Harris Stone Quarry, Bainbridge, Indiana.-------------------------------------------- 42

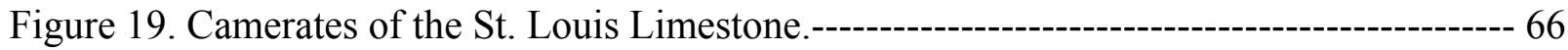

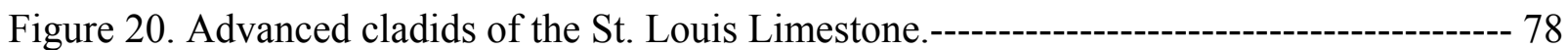

Figure 21. Crinoids added, not previously assigned to the St. Louis Limestone, plus St. Louis

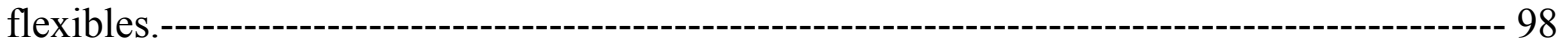

Figure 22. Relative number of crinoids genera throughout the Phanerozoic.---------------------102

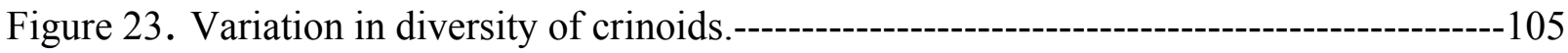

Figure 24. Representative examples of groups of crinoids from the Paleozoic.------------------106

Figure 25. Demonstration of marine circulatory patterns with and without reefs.----------------107

Figure 26. Change in number of crinoid genera from the late Osagean to the early Chesterian.

Figure 27. Trends in calyx morphology of advanced cladids from the Osagean through the

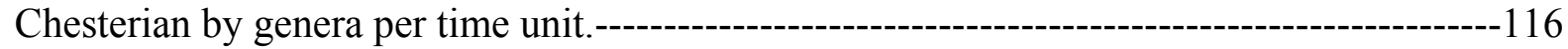

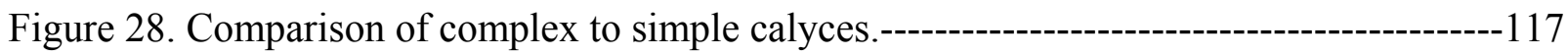

Figure 29. Examples of change in number of genera within camerate families through the mid

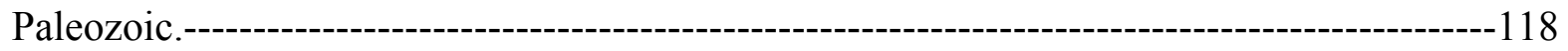

Figure 30. Distribution of number of genera of crinoids and predatory fish through the Middle

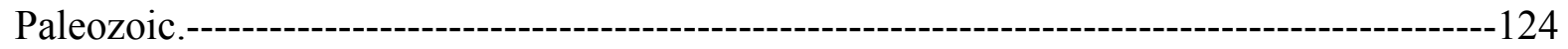

Figure 31. Diversity of advanced cladids versus chondrichthyes from the Devonian through the 
Figure 32. Diversity of camerates versus chondrichthyes from the Devonian through the

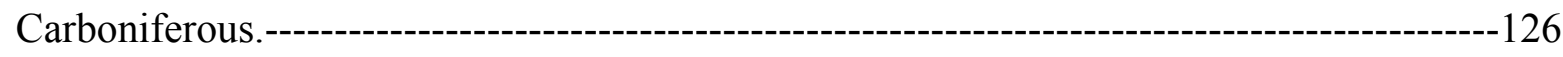

Figure 33. Diversity of camerates and advanced cladids compared to ammonoids from the

Devonian through the Carboniferous.---------------------------------------------------------------127

Figure 34. Spinosity and thick plated Paleozoic Crinoids.-------------------------------------------128

Figure 35. Distribution of crinoid genera parasitized by Platyceratids during the Paleozoic.

Figure 36. Per cent of crinoids found in Paleozoic crinoids with regenerating arms from non-

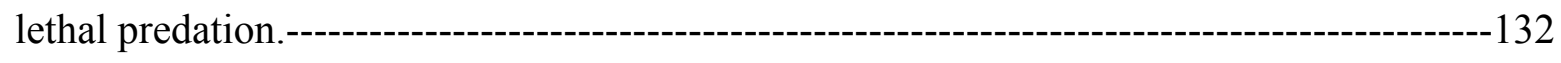

Figure 37. Sea level changes during the Mississippian in the Illinois Basin.-------------------135

Figure 38. Collapse breccias at Harris Stone Quarry, Bainbridge, Indiana.-----------------------136

Figure 39. Stratigraphic section of the lower to middle St. Louis Limestone in southwestern

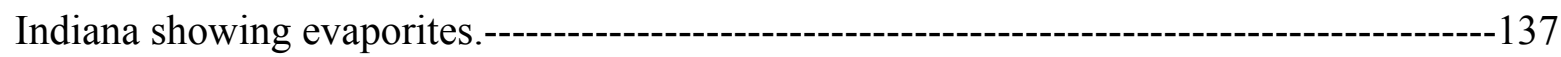

Figure 40. Sea-level change and number of camerate and advanced crinoid genera in the Illinois

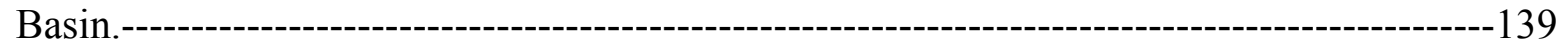




\section{List of Tables}

Page

Table 1. Correlation chart showing relationship of sequences to standard chronographic

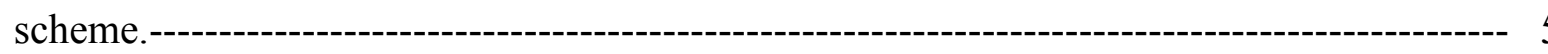

Table 2. Boundary changes around the Meramecian during the nineteenth and twentieth

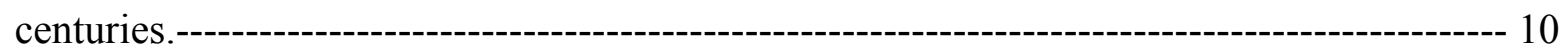

Table 3. Five categories of crinoid analysis.---- 45

Table 4. Distribution of genera through the Osagean, Meramecian and Chesterian.-----------112

Table 5. Seriation of camerate and advanced cladid genera through the Osagean, Meramecian

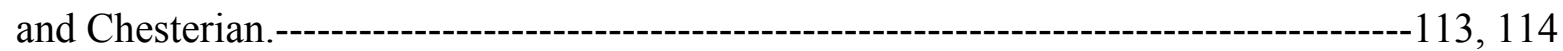

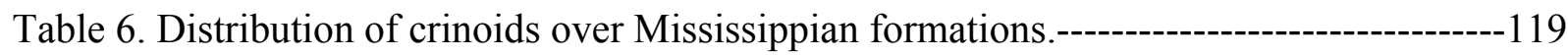




\section{Introduction}

Crinoid workers have described important transitions in the macroevolution of crinoids from the Early to the Middle and finally the Late Paleozoic (Baumiller, 1993, 1994; Ausich, et al., 1994; Kammer and Ausich, 2006). The transition from the Middle to Late Paleozoic crinoid macroevolutionary fauna took place during the Mississippian. During the early Osagean Stage, monobathrid camerates dominated, whereas during the late Mississippian Chesterian Stage, advanced cladids dominated (Ausich, et al., 1994).

The Meramecian Stage lies between the Osagean and the Chesterian, indicating the likelihood that at least a part of the transition in faunal dominance occurred during that time period. Some workers think that the mass extinction event at the end of the Devonian was not as strong an influence over that transition as were the environmental changes during the Mississippian. They concluded that facies changes, predation, sea level changes, habitat loss, autecology and species competition may be more reasonable explanations (Baumiller, 1993, 1994; Ausich, Kammer, Baumiller, 1994; Kammer and Ausich, 2006).

The macroevolutionary transition of crinoids during the Meramecian was most apparent during the time of the formation of the St. Louis Limestone. The preceding Salem Limestone contained crinoid fauna dominated by camerates. In the following Ste. Genevieve Limestone dominant camerates gave way to dominance by advanced cladids. The details of that change have not been well understood, particularly because of lack of 
study of the St. Louis Limestone crinoid fauna since its initial description in the late 1800s.

In order to present an organized study of the transition of crinoid faunas during the deposition of the St. Louis Limestone, the following must be addressed: 1. A thorough evaluation of the geologic setting before, during and after the formation of the St. Louis Limestone should include evidence of any environmental changes that may have influenced the change in taxa. 2. A re-evaluation of the crinoid taxa that lived during St. Louis time must be done using modern systematics in order to better understand which taxa were actually present. 3. Use the modern understanding of the position of the St. Louis- Ste. Genevieve boundary to separate the crinoid faunas of these two formations. These two formations were once placed in the larger St. Louis Group, which created confusion about the exact stratigraphic placement of some $19^{\text {th }}$ century crinoid collections. A new crinoid collection from Putnam County, Indiana, served as a reference for known St. Louis Limestone crinoid occurrences. 4. An evaluation of the evolutionary paleoecology that may have accompanied the transition of crinoid fauna; the combined study of changes in the crinoid morphology, environment, autecology and synecology would, indirectly, offer an explanation for the transition during that time frame. That organizational structure will be followed in this work. 


\section{Geologic Setting}

\section{Introduction}

An overall understanding of the geologic setting of the Illinois Basin is an integral component of understanding the particular environments of the Mississippian Period. The environments during the Meramecian were important factors in the changes that took place in the biota of the time. The origin of the geology and the resulting morphology of the Illinois Basin and its components must be understood to interpret the change in biota in a systematic way. In addition, lithologies and depositional environments must be investigated in order to interpret the paleoecology. With that in mind, a more accurate assessment of the evolution of crinoids through the Meramecian will be possible.

\section{Origin of the Illinois Basin}

During the Late Proterozoic, the separation of the continental plates, Laurentia and Avalonia (Kearey et al, 2009), resulted in an extensional stress across the North American craton (Hinze, et al. 1988). It is thought that the development of the New Madrid Rift complex was the beginning of the development of the Illinois Basin (Collinson, 1988).

The Illinois Basin is bounded by several elevated areas (Figure 1); the Kankakee Arch to the north which separates the Illinois and Michigan basins; the Mississippi River Arch to the west; and the Cincinnati Arch to the east. These latter two arches separate the 
Illinois Basin from the Forest City Basin to the west and the Appalachian Basin to the east. The Ozark Uplift lies just south of the Mississippi River Arch. The Pascola Arch, which was uplifted during the Pennsylvanian to the Cretaceous Periods, lies just south of the Illinois Basin. During most of the Paleozoic, the Illinois Basin was open on its southern border to the Mississippian Embayment (Collinson, 1988). The geographical area comprising the Illinois Basin includes parts of Indiana, Illinois, Missouri and Kentucky. During the Paleozoic, as much as 3,000 meters of sedimentary rocks accumulated in this basin (Collinson, 1988).

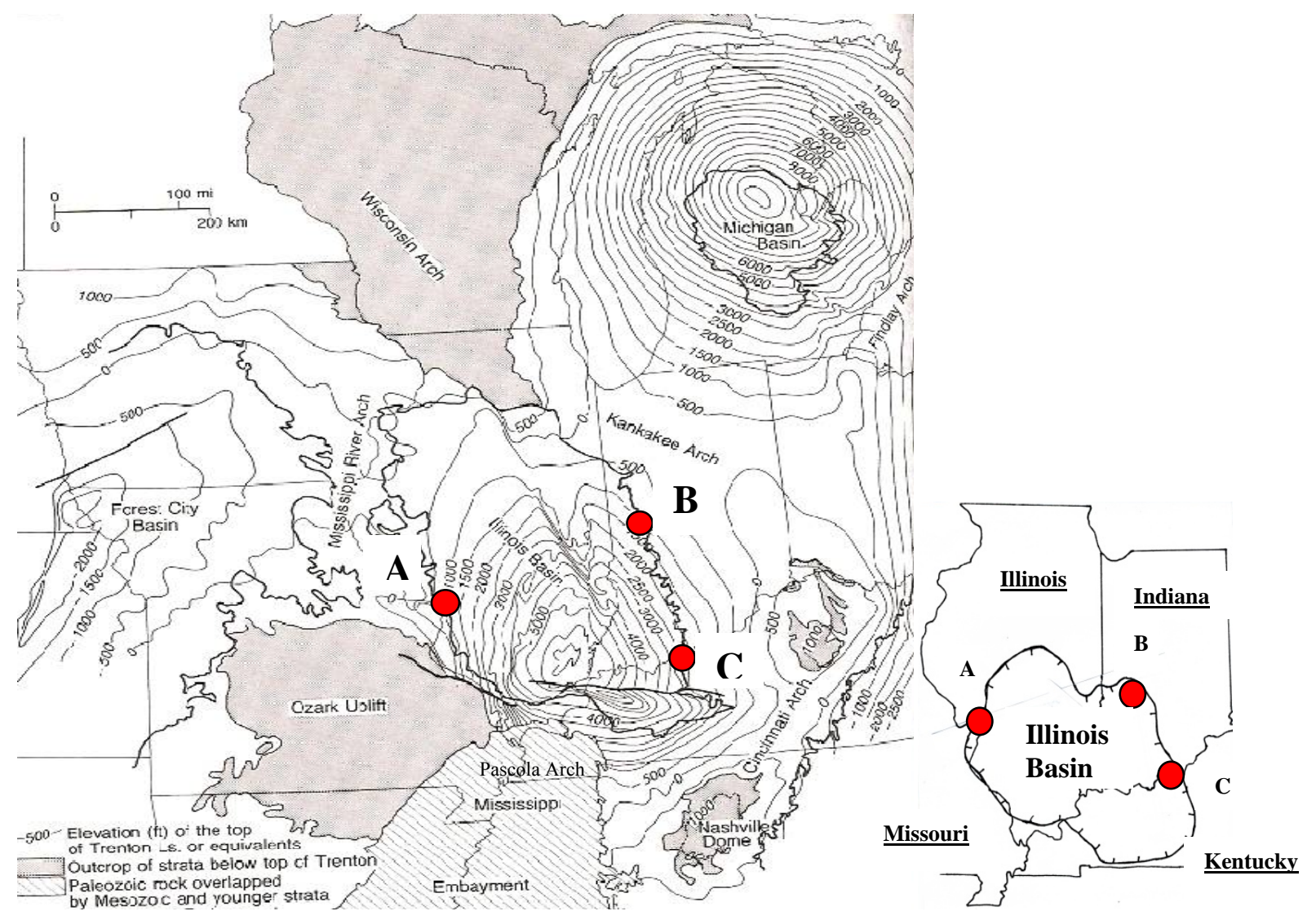

Figure 1. Map of north central United States showing major basins, arches and domes (Sloss, 1998). Sources of specimens for this study: A, Casper Stolle Quarry, Alton, Illinois and Columbia, Illinois; B, Harris Stone Quarry, Bainbridge, Indiana; C, Outcrops just south of Croydon, Indiana and site of thin sections A, B, C, and D of Figure 13. 
Sloss (1988) devised a scheme of unconformity-bound sequences in the North American cratonic interior. His scheme is comprised of six sequences, with subdivisions that conform to the chronostratigraphic layers. Sloss's (1988) sequences encompassed the late Precambrian through the present (Table 1).

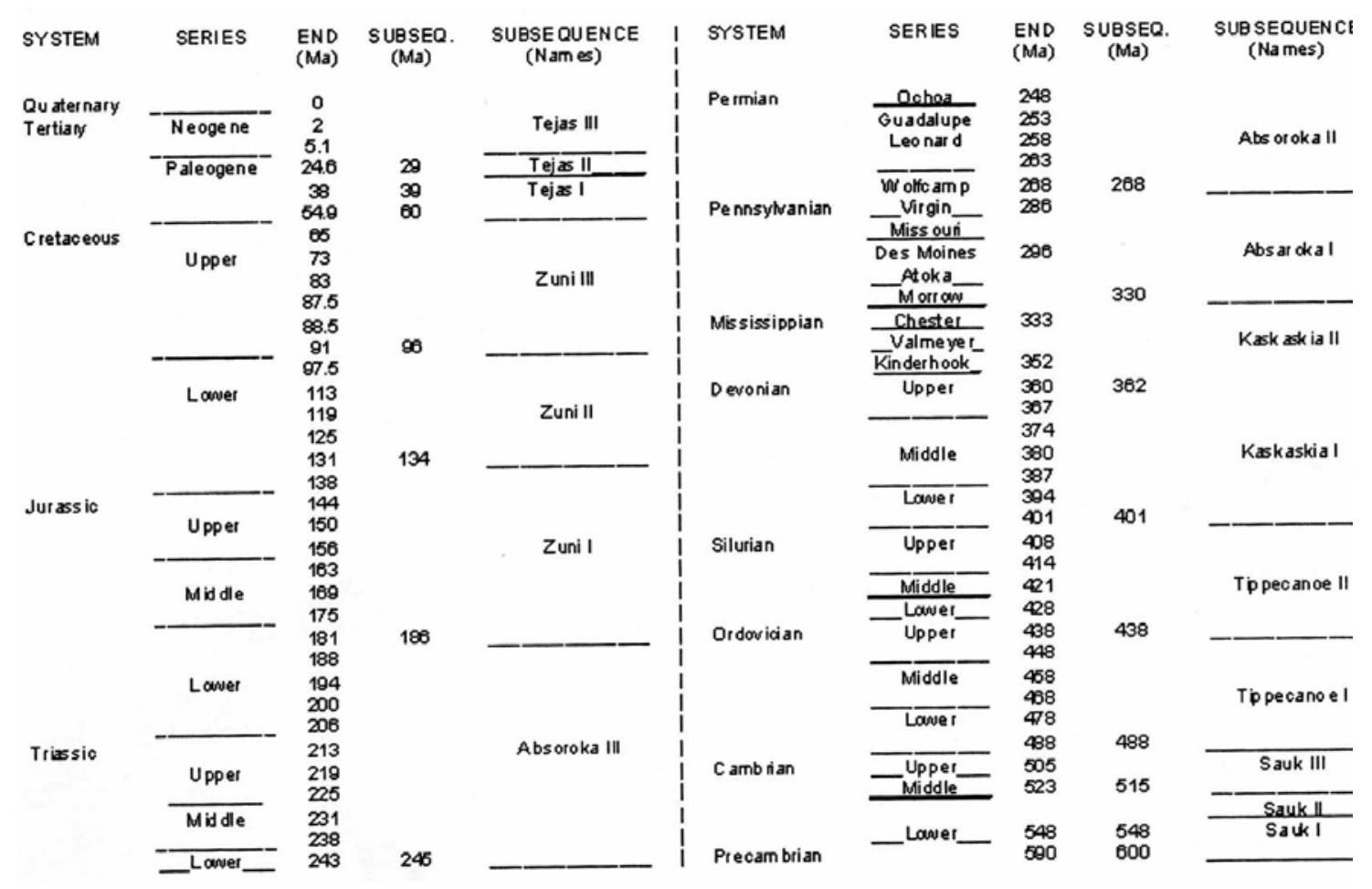

Table 1. Correlation chart showing relationship of sequences to standard chronographic scheme. (At the time of this work by Sloss, the Valmeyeran was comprised of the Osagean and Meramecian) (Sloss, 1988). 


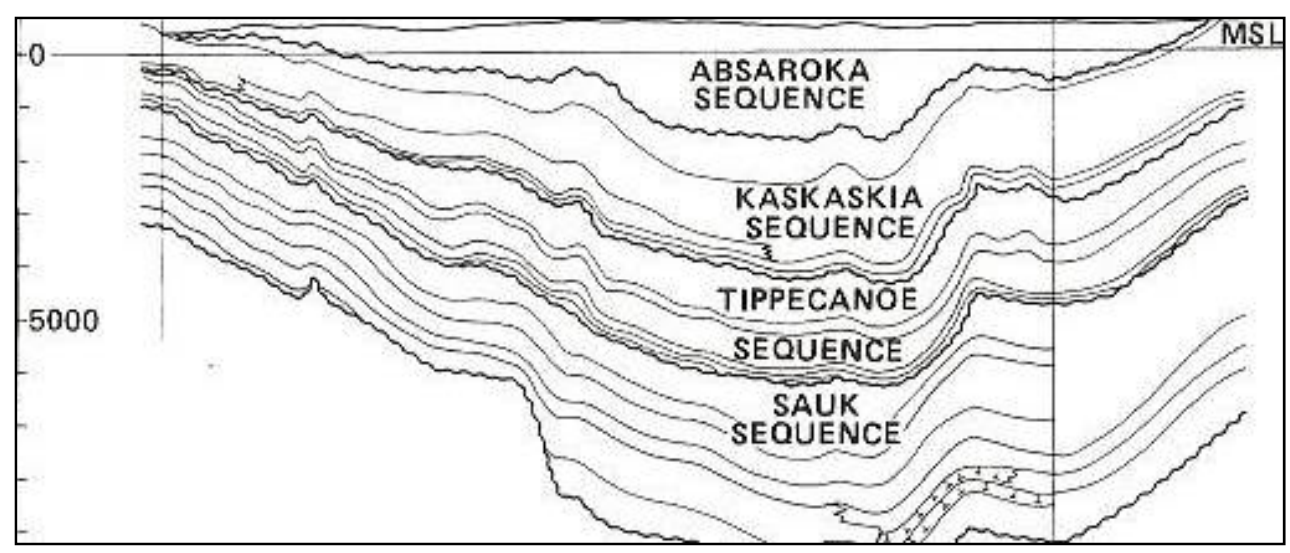

Figure 2. Geologic cross-section of the Illinois Basin below the Zuni and Tejas Sequences (Collinson et al., 1988).

The Sauk through the Absaroka sequences (Figure 2), which comprise the sedimentary fill of the Illinois Basin, formed between 590 and 245 million years ago. The progression of sequences began with the Sauk Sequence, followed by the Tippecanoe and Kaskaskia sequences. The Sauk and Tippecanoe sequences were deposited during the first 150 million years of the Paleozoic Era (Collinson, 1988). The Sauk Sequence was deposited over the Precambrian basement unconformity. Erosion resulted in an unconformity at the top of the Sauk sequence. The Tippecanoe sequence resulted from the deposition of sandstone followed by limestone then shale. The overlying Kaskaskia sequence is divided into two depositional subdivisions, Kaskaskia I and II. Kaskaskia I occurred through the Devonian period whereas Kaskaskia II represents the Mississippian period extending through most of the Chesterian age and includes the Salem, St. Louis and Ste. Genevieve limestones. Further tectonic events occurred during Kaskaskia I that accentuated the domes and arches. Sediment came from all directions, resulting in shales, sandstones and carbonates, as in previous sequences (Collinson, 1988). 
The Kaskaskia II subsequence began with transgression and establishment of an opencirculation and carbonate-dominated sea. Within that time period deltas prograded across Ohio, Indiana and Illinois in short pulses, depositing sand and mud from the northeast. Deposition of clastics became more pronounced in the later Mississippian. Subsidence rates were 30-40 meters per million years in southern Illinois gradually decreasing around the periphery of the Illinois Basin to 5-10 meters per million years. As a result, the thickness of each formation was greatest in the center of the basin (Sloss, 1988). The combined thickness of the Salem, St. Louis and Ste. Genevieve limestones was 940 feet (285 meters) in the basin's center (Lineback, 1972; Carr, et al., 1986; Rexroad, 1986; Treworgy, 1990). The sea floor in the Illinois Basin was a shallow platform shelf with water depths of 30 to possibly as deep as 500 feet (9-152 meters) (Treworgy, 1990), it was more shallow toward the north and deeper toward the south (Figure 3). The lateral boundaries of the Salem, St. Louis and the Ste. Genevieve formations were limited by the periphery of the basin where the thicknesses tapered to zero. 


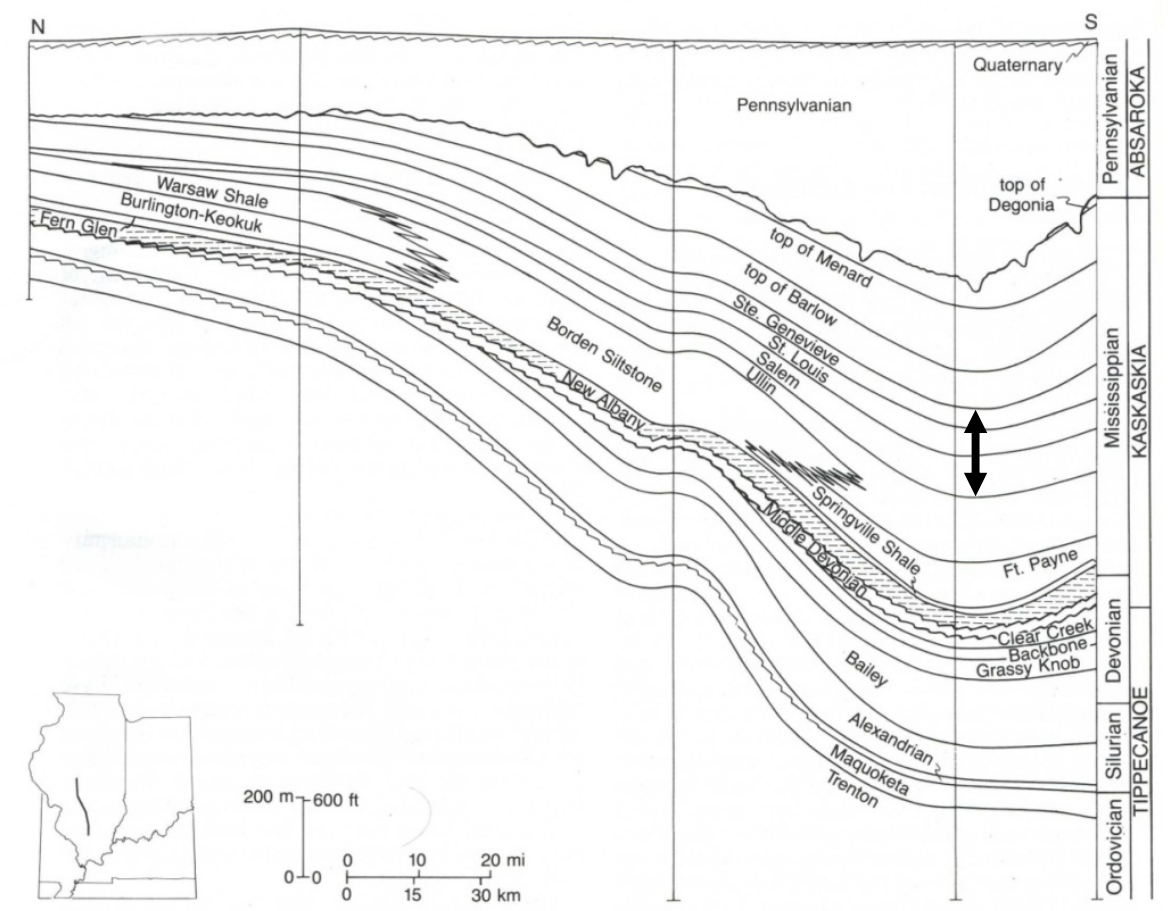

Figure 3. North-south cross section of the Illinois Basin. Note the Salem, St. Louis and Ste. Genevieve limestones marked by arrow (Bethke et al.,1990).

In the Illinois Basin during the Osagean Stage (part of Kaskaskia II), a prodelta mud, the New Providence Shale (in Indiana, this is just below the Borden, not shown on figure 3), formed; followed by the Fort Payne Chert, a siliceous, carbonate mudstone. From that time forward, during the Meramecian Stage and completing the Kaskaskia II sequence, all formations were carbonates; in ascending order, the Harrodsburg (in Indiana, this is just below the Salem, not shown on figure 3), Salem, St. Louis and Ste. Genevieve limestones. Other designations for these rocks are the Saunders Group (Harrodsburg and Salem formations) and the Blue River Group (St. Louis and Ste. Genevieve formations along with the Aux Vases and Renault formations) (Collinson, 1988) (Figure 4). 


\begin{tabular}{|c|c|c|c|c|}
\hline \multicolumn{2}{|c|}{ Illinois-Missouri Type Areas } & \multirow[b]{3}{*}{ - } & \multirow[b]{3}{*}{$\bar{\Xi}$} & Indiana Outcrop \\
\hline \multirow{2}{*}{\multicolumn{2}{|c|}{$\begin{array}{l}\text { Bethel Formation } \\
\text { Downevs Bluff Limestone }\end{array}$}} & & & Bethel Formation \\
\hline & & & & Downeys Bluff Limestone \\
\hline \multicolumn{2}{|c|}{ Yankeetown Sandstone } & \multirow{3}{*}{$\underset{\widetilde{\sigma}}{\stackrel{\varpi}{\sigma}}$} & $\stackrel{一}{ٍ}$ & Yankeetown Sandstone \\
\hline & $\begin{array}{l}\text { Shetlerville } \\
\text { Limestone Member }\end{array}$ & & 点. & Shetlerville Member \\
\hline \multirow[t]{2}{*}{$\begin{array}{l}\text { Renault } \\
\text { Limestone } \\
\end{array}$} & & & 总 & Popcorn Member \\
\hline & Levias Limestone Member & \multirow{2}{*}{ 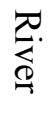 } & $v_{1}$ & \multirow{4}{*}{ Levias Member } \\
\hline \multicolumn{2}{|c|}{ Aux Vases Sandstone } & & $\overrightarrow{0}$ & \\
\hline & Joppa Member & \multirow{4}{*}{$\begin{array}{l}\cong \\
0 \\
0 \\
0\end{array}$} & बे & \\
\hline \multirow{3}{*}{$\begin{array}{l}\text { Ste. Genevieve } \\
\text { Limestone }\end{array}$} & Karnal Ls. Member & & ؛्. & \\
\hline & Spar Mountain Ss Member & & कृ & Spar Mountain Member \\
\hline & $\begin{array}{l}\text { Fredonia Limestone } \\
\text { Member }\end{array}$ & & is & Fredonia Member \\
\hline \multicolumn{2}{|c|}{ St. Louis Limestone } & \multirow{2}{*}{-} & & St. Louis Limestone \\
\hline \multicolumn{2}{|c|}{ Salem Limestone } & & & Salem Limestone \\
\hline
\end{tabular}

Figure 4. Correlation of stratigraphic units across Illinois, Indiana and Missouri (Modified from Shaver, 1986; Indiana Geologic Survey, 1997).

\section{Mississippian and Meramecian Stratotypes}

The Mississippian Period was proposed by Alexander Winchell in 1869 as a name for the limestones which occurred along the Mississippi River Valley. In 1891, H.S. Williams defined the interval as being above the Devonian and below the Coal Measures. The stratotype is represented by a 20-mile section along the Mississippi River north of Burlington, Iowa (Collinson, et al., 1979).

The Meramecian Stage was defined by E. O. Ulrich in 1904 as the Meramec Group. It was made up of the Warsaw, Spergen Hill (Salem) and St. Louis limestones. The type section for the Meramec Group was located around the Meramec Highlands Quarry 
which lies along the Meramec River west of St. Louis. In 1904, Ulrich proposed the term Meramecian (Lane and Brenckle, 2005).

The designations of boundaries and names of formations within the Mississippian Epoch has been a complicated process. This has resulted in confusion in evaluating the systematics and paleoecology of fossil fauna through that time period. The specific history of each of the three formations discussed herein, Salem, St. Louis and Ste. Genevieve limestones will be discussed in the sections of this work devoted to them. The overall scheme is summarized in Table 2 .

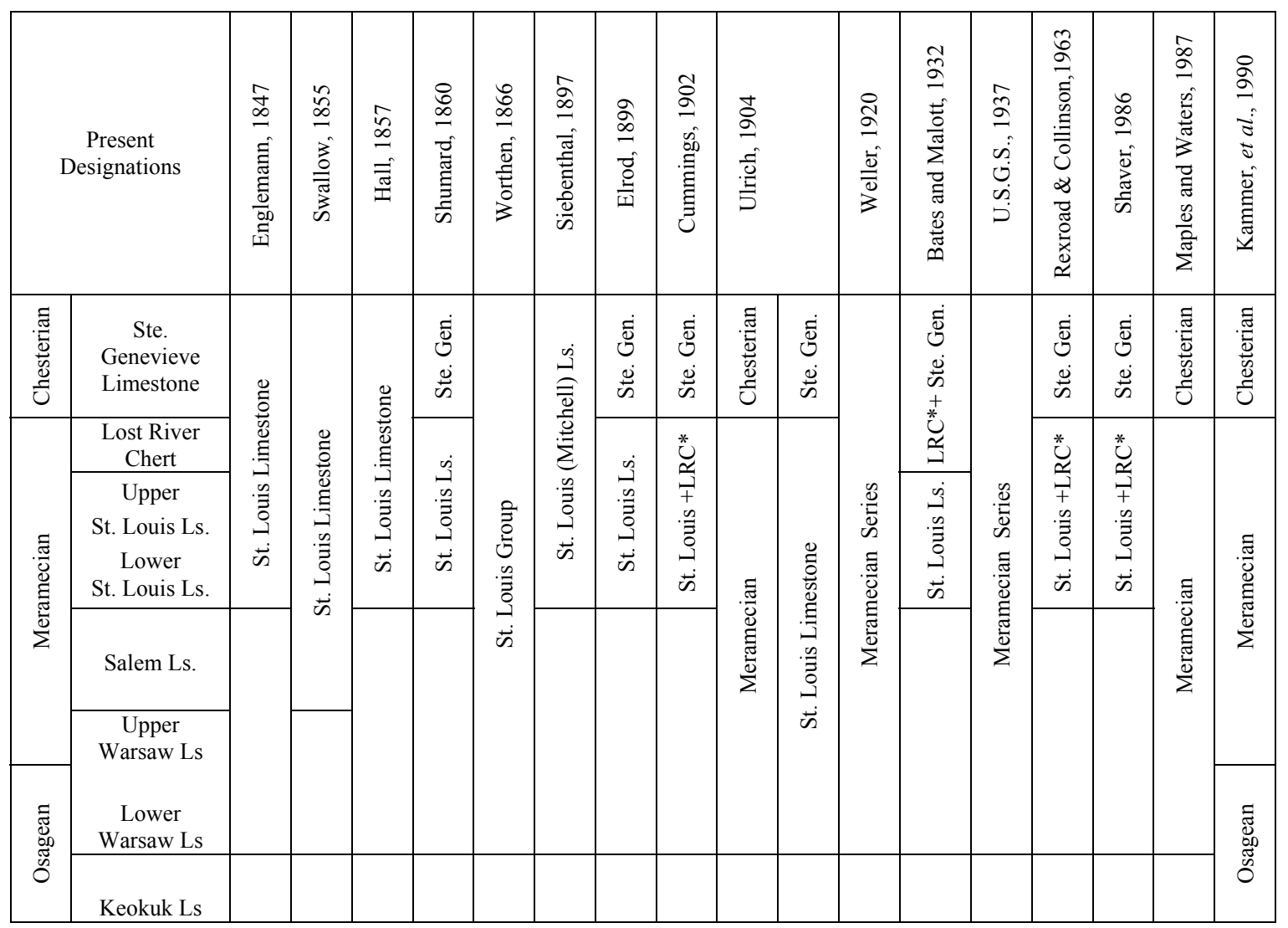

Table 2. Boundary changes around the Meramecian during the nineteenth and twentieth centuries. $(*)$ L.R.C.- Lost River Chert. 


\section{Formations within the Study Area}

Although the focus of this study is the St. Louis Limestone, the formations above and below the St. Louis Limestone will also be discussed. These are the Salem Limestone below and the Ste. Genevieve Limestone above. This approach will provide data which will allow across-time comparison of paleoenvironments. (Refer to Appendices B and C for the stratigraphic columns from the eastern and western portions of the Illinois Basin marked $\mathbf{A}$ and $\mathbf{B}$ in figure 1)

\section{THE SALEM LIMESTONE}

\section{DESIGNATION}

The Salem Limestone's type locality was not specifically designated by E. R. Cummings in 1901 when he named this formation from an area nearby at the edge of Salem, Washington County, Indiana. This limestone had been quarried in the area thought to be where Gorby described the Salem Limestone in 1886. He described it as lying between the Harrodsburg Limestone below and the Mitchell Limestone above. At that time the Mitchell Limestone was the combination of the present day St. Louis, Ste. Genevieve and the Paoli limestones. The Salem Limestone had been quarried since 1827 and had been given different names in different places throughout the Illinois Basin area. It was usually named by the nearest town with the added term, "stone". Examples include Bedford Stone, Bloomington Stone, and White River Stone. The most common name used for many years was Spergen Hill or Spergen Limestone by E. O. Ulrich in 1904. 
The U. S. Geological Survey changed the name to Salem Limestone in the 1950s

(Keroher, 1966; Rexroad, 1986).

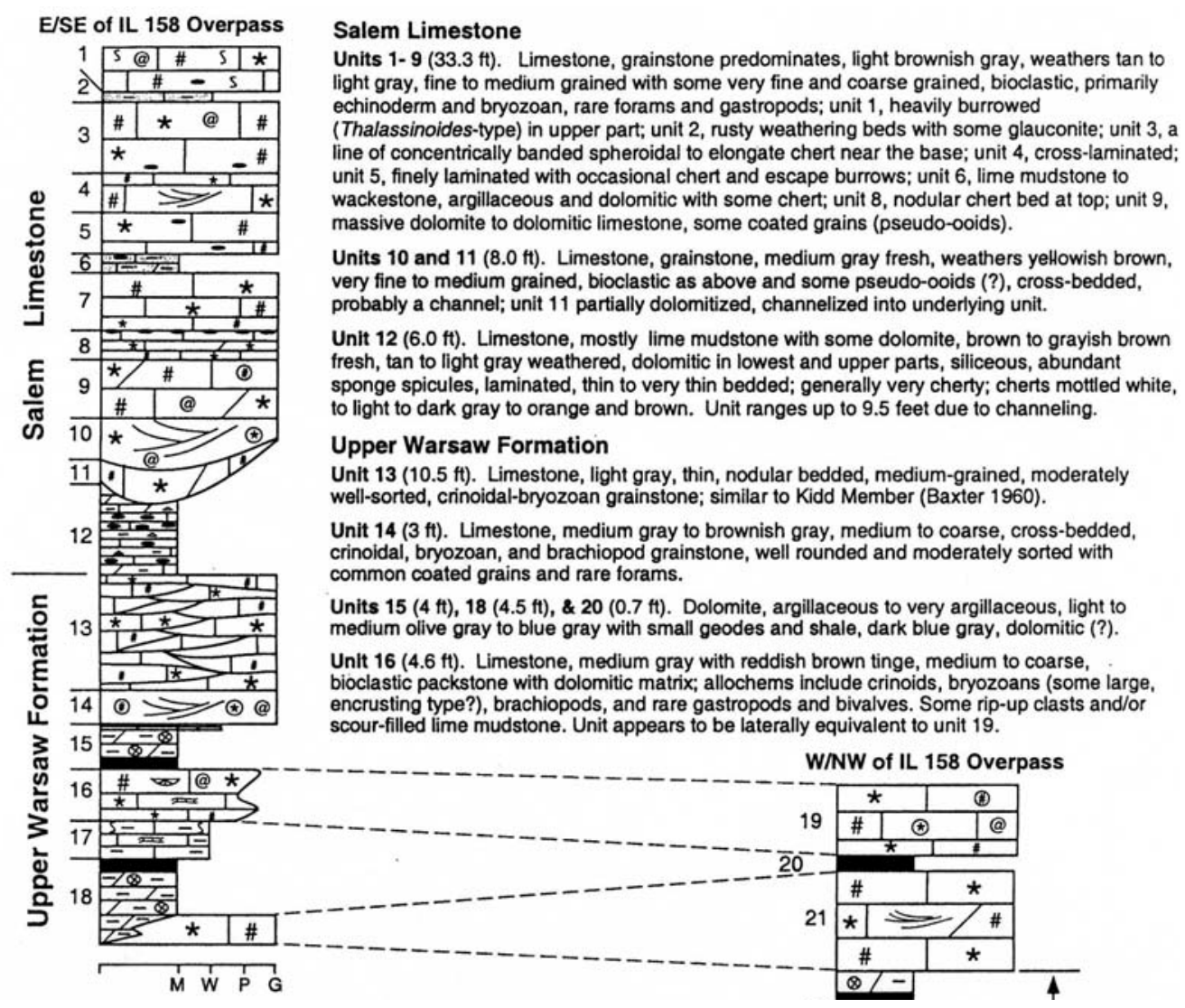

Figure 5. Stratigraphy column of Salem Limestone and upper Warsaw Formation,

Columbia, Illinois, on the western edge of the Illinois Basin. Units in feet. See key to symbols, Appendix A (Lasemi et al., 1999).

\section{LITHOLOGY}

The most common lithology in the Salem Limestone is calcarenite (or biocalcarenite, to account for its high content of fossils) (Figure 5). Lesser amounts of dolomite, sandstone, chert and evaporites are also included. The Salem Limestone contains a variety of fossils including foraminifera, gastropods, bryozoans and crinoids. The fossil fragments are rounded and broken and the limestone is crossbedded. The matrix includes some micrite 
but is predominantly sparite. In some areas the Salem is very fine grained and dense, but in most areas it is medium to coarse. Oolites are present locally (Lineback, 1972;

Rexroad, 1986). In Illinois, the Salem Limestone consists of grainstone and packstone in some areas with wackestone and mudstone in other areas. Toward the east it gradually changes into predominately grainstone and packstone (Treworgy, et al., 1990). Lasemi and Norby (1999) divide the Salem into lower and upper members. The lower Salem is cherty, spiculitic, argillaceous and dolomitic around St. Louis. Toward the south of the Illinois Basin, it is a crinoidal, bryozoan and peloidal grainstone (Figure 6). The upper Salem is more oolitic, peloidal and foraminiferal grainstone (Lasemi and Norby, 1999).

The Salem Limestone varies in thickness, most commonly from 60 to 100 feet on outcrops in Indiana, but in the subsurface it is noted to be as thick as 280 feet in southern Indiana and up to 500 feet in Illinois (Lineback, 1972; Rexroad, 1986; Lasemi and Norby, 1999). At the Harris Stone Quarry at Bainbridge, Putnam County, Indiana (Figure 1), it is 36.3 feet (Figure 10). It extends across the Illinois Basin in Indiana, Kentucky and Illinois to beyond the Transcontinental Arch (Qi et al, 2007) and pinches out to the north in Illinois and Indiana (Lineback, 1972, Rexroad, 1986). 
A

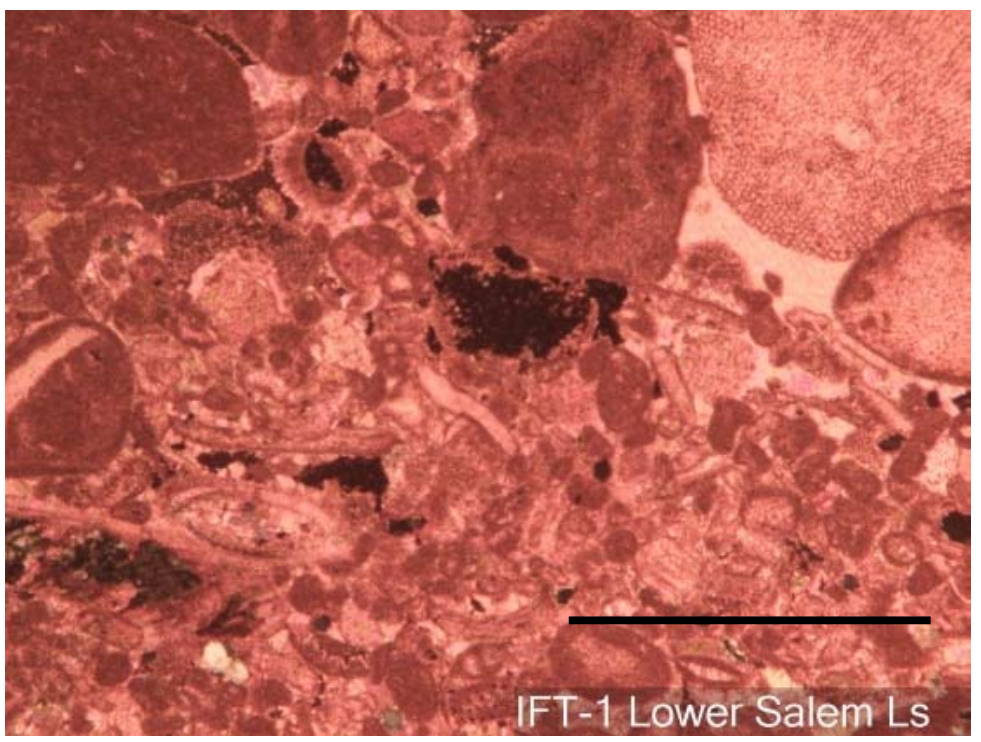

Figure 6. Salem

Limestone

photomicrographs.

The red color is from Alizarin stain
$\underline{\mathbf{A}}$ and $\underline{\mathbf{B}}$ are from Floyd County, Kentucky, and contain ooids, peloids and crinoid plates. Note they are free of micrite.
B

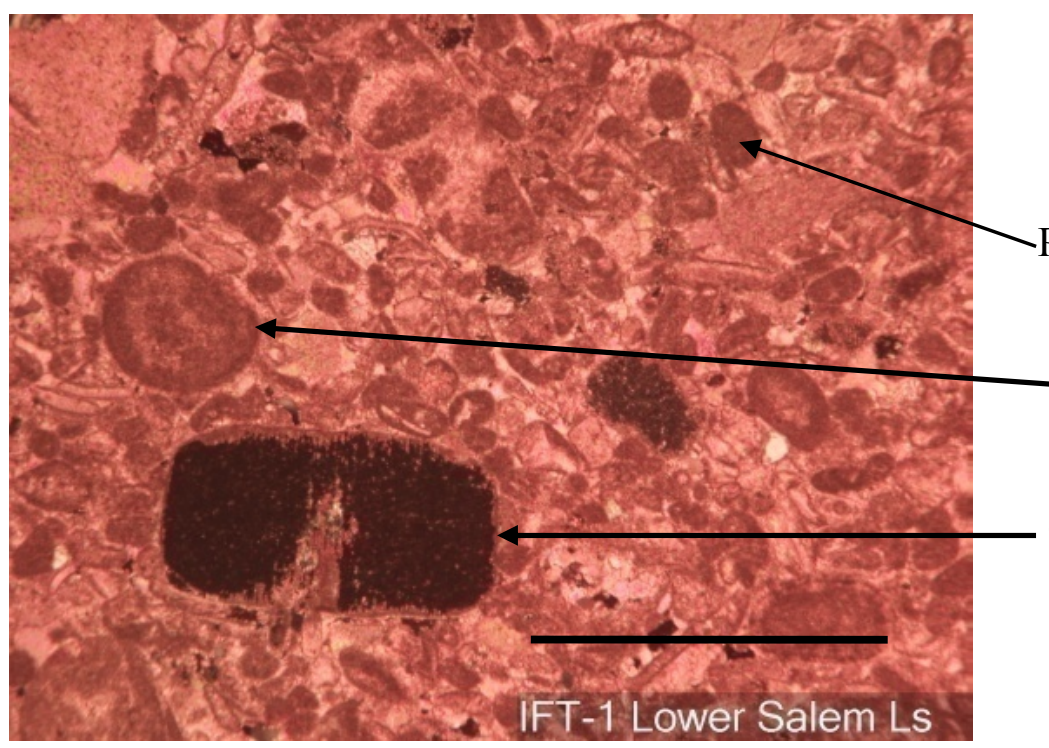

Chert

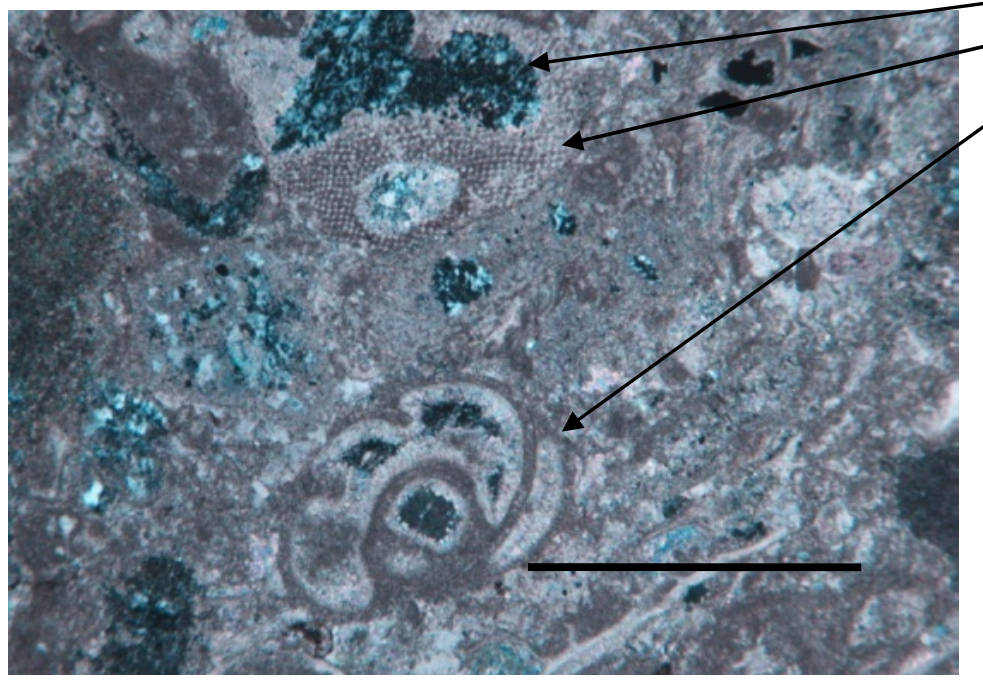

Crinoid plate Foraminifera

$\underline{\mathrm{C}}$ is from the Harris Stone Quarry, Putnam County, Indiana. It contains foraminifera, crinoid and other skeletal debris along with micrite and some quartz. Scale Bar $=$ One Millimeter.XPL 


\section{DEPOSITIONAL ENVIRONMENT}

The Salem Limestone was deposited in three facies of the near-shore carbonate environment. These include tidal channels, intervening shoals with tidal flat and adjacent lagoon. The channel facies has crossbedding, with medium to coarse skeletal grainstone that is well sorted and abraded, all of which indicate a high energy environment. The Salem has trough crossbedding with channels up to 15 feet (5 meters) deep. The crossbedding is oriented northeast-southwest (Feldman, et al., 1993). The Salem has at least three shoaling-upward cycles (Martorana, 1987, reports four) comprised of a shoal facies followed by a tidal flat facies (Martorana, 1987; Lasemi and Norby, 1999). These two facies resulted in two distinct lithologies. In the high energy, open marine shoal environment grainstone was present. This was covered with oolitic packstone and coated skeletal fragments in the tidal flat. These fragments had a high degree of sorting and rounding, crossbedding, and winnowing along with no associated bioturbation.

The lagoonal facies was a much lower energy environment behind the shoals. It contained oolitic packstone, peloidal packstone, and a higher concentration of mud and bioturbation. This facies also included algal laminations and fenestral structures, indicating a restricted marine environment (Dodd, 1987; Martorana, 1987). Lasemi and Norby (1999) described the more western part of the Illinois Basin as three units which include a thin carbonate conglomerate, a thick shoal facies followed by a thin argillaceous lime mudstone and dolomite. This configuration represents a more open marine subtidal faces. 


\section{THE ST. LOUIS LIMESTONE}

\section{DESIGNATION}

The designation of the St. Louis Limestone was first made by George Engelmann in 1847 from outcrops near St. Louis, Missouri. The boundaries were not clearly defined (Engelmann, 1847; Wilmarth, 1938; Rexroad and Collinson, 1963; and Shaver et al., 1986), and included more stratigraphic section than do present-day boundaries. Swallow (1855) placed the St. Louis Limestone between the Warsaw and Aux Vases Formations (Rexroad, 2000). Shumard (1860) included the later defined Salem (Spergen) Limestone in the St. Louis Limestone and named the overlying Ste. Genevieve Limestone. Worthen (1866) defined the "St. Louis Group" for rocks above the Keokuk Group and below the Aux Vases Formation, spanning the modern Warsaw through Ste. Genevieve limestones in Illinois. This is equivalent to the later Meramec Group of Ulrich, 1904 (Wilmarth, 1938). Shumard's (1860) Ste. Genevieve was ignored by other workers until Ulrich (1904) revived the name. In 1897, Siebenthal included the St. Louis within the Mitchell Limestone. In 1899, Elrod incorporated the Mitchell Limestone, the Salem Limestone and the Lost River Chert together as the St. Louis and separated out the Paoli Limestone which included the Ste. Genevieve Limestone. Ulrich (1904) limited the St. Louis Limestone to the strata above the Salem Limestone (previous know as Spergen Hill Limestone of Indiana now called Salem Limestone) and below the Ste. Genevieve Limestone. The upper part of the Warsaw Formation was originally included within the Salem Limestone by Hall (1857). The St. Louis Limestone was always considered to be above the Salem Limestone or its equivalent (Kammer et al., 1990). Cummings (1922) included the Lost River Chert within the St. Louis Limestone. In 1932, Bates and Malott 
placed that chert within the Ste. Genevieve Limestone. Those designations continue to stand, but because of similar lithologies and confusion concerning faunas, the precise formational boundaries were difficuly to distinquish (Rexroad and Collinson, 1963).

These formational and stage designations were disputed in the early $20^{\text {th }}$ century between two leaders in geology at the time. Ulrich (1847) had conceived the Meramecian Series (He used the term "Series" instead of "Stages" by Maples and Waters, 1987) to be the Warsaw, Spergen Hill and St. Louis limestones that were exposed in a quarry along the Meramec River, southwest of St. Louis. Stuart Weller (1920), on the other hand, included the Ste. Genevieve in the Meramecian. Ulrich's designation held until 1937 when the United States Geological Survey adopted Weller's view and included the Ste. Genevieve within the Meramecian Series (Maples and Waters, 1987; Lane and Brenckle, 2005).

The "St. Louis Group" was a parallel name that was initiated by Worthen (1866). He defined this group as overlying the Keokuk Group and underlying the Chester Group. At that time, the presently-designated Ste. Genevieve Limestone was considered to be the upper part of the St. Louis Limestone. As a result, the combination of what is the presentday Warsaw, Salem, St. Louis and Ste. Genevieve was referred to as the St. Louis Group. The St. Louis Group appears to have been shortened to the "St. Louis" on museum labels and systematic indexes, thus obscuring whether it referred to the formation or the larger group. Crinoids that were found within that range of formations were often designated as 
being in the St. Louis and not updated as each of the included formations was better defined (Table 1).

R. C. Moore (1933) combined the Osagean and Meramecian Series together as the Valmeyeran Stages, a term that was used in Indiana and Illinois (Moore, 1933; Atherton, et al., 1975; Maples and Waters, 1987). The name came from the town of Valmeyer, Illinois, south of St. Louis. The Dennis Hollow section, just southeast of Valmeyer, is the reference section. Swann (1963) described the Valmeyeran Stages as extending from the Fern Glen Formation, at the bottom of the Osagean, to the base of the Renault Limestone, the lower unit of the Chesterian Series (Lane and Brenckle, 2005). In 1987, Maples and Waters went back to the original idea of Ulrich, removing the Ste. Genevieve Limestone from the Meramecian and placing it as the lowest unit of the Chesterian (Waters and Maples, 1987). Their rationale for doing this was to place the Ste. Genevieve in the Chesterian series where it is more closely allied faunally and depositionally.

The Lost River Chert bed is located in the upper St. Louis Limestone (Lasemi et al., 1999). The upper boundary of the Lost River Chert Bed is also the boundary between the Synclydognathus geminus and Hindeolus cristulus conodont fauna that marks the St. Louis Limestone/Ste. Genevieve boundary (Collinson et al., 1971; Rexroad et al. 1990). By analyzing the fossil occurrences across the Meramecian-Osagean boundary, Kammer et al., (1990) defined the base of the Meramecian as the boundary between the upper and lower parts of the Warsaw Formation. They related that Hall and Ulrich had previously indicated that boundary to be the base of the Warsaw Limestone or the lower boundary of 
the Meramecian. The currently recognized lower Warsaw was originally part of the

Keokuk Limestone or Group. Kammer et al. (1990) concluded that with a clearly defined

Meramecian Stage, there was no real need for the Valmeyeran Stage.

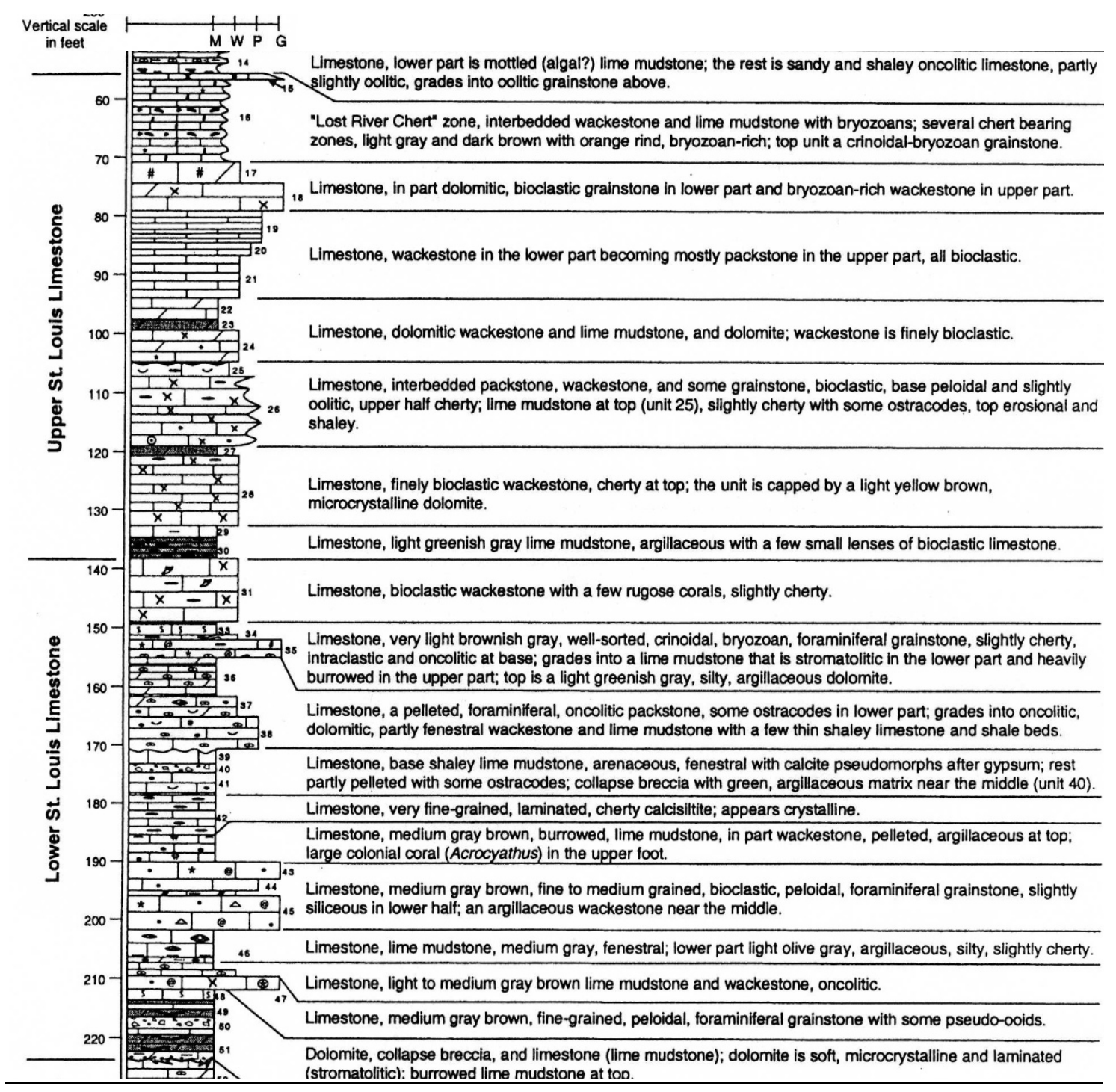

Figure 7. Stratigraphic column, St. Louis Limestone at Casper Stolle Quarry, south of

Alton, Illinois (Figure 1). See key to symbols, Appendix A (Lasemi, et al., 1999). 


\section{LITHOLOGY}

Overall, the St. Louis Limestone is dominated by mudstone with chert, skeletal wackestone, skeletal packstone, dolomite, with large amounts of gypsum and anhydrite (Treworgy, 1990) (Figure 11 and Figure 39). This formation is divided into two parts, lower and upper, on the basis of lithology (Figure 7). The lower part is "mainly pelletmicritic limestone, calcareous shale and silty dolomite" (Rexroad, 1986, p.126) but also contains anhydrite and gypsum. The upper part contains mostly micrite with thin beds of shale, as well as pelloidal and skeletal limestone. Although found in various positions in the past, chert nodules are considered to be in the upper part of the St. Louis Limestone (Hattin and Dodd, 1992). They range from one to five centimeters in diameter and are spherical to lenticular in shape (Woodson, 1981). These nodules were obvious in the Harris Stone Quarry (Figure 8). Pockets of quartz sand are also found in the Harris Stone Quarry, but they were probably washed in at a later time, filling solution cavities that developed in the carbonates (Smith, et al., 1961). Collapse breccias occur in the St. Louis Limestone and are especially obvious at the Harris Stone Quarry (Figure 9). Opinions vary as to the possible causes for these features. One possibility includes the solution of evaporites causing loss of support and collapse. Another is tectonic activity causing a submarine rock slump. Still another possibility would be a combination of both (Smith, et al., 1961; Collinson et al., 1979). Dolomite beds are interbedded through the St. Louis and range in thickness from inches to 30 feet (9 meters) (Treworgy, 1990). In the St. Louis Formation at the Harris Stone Quarry, collapse breccias and dolomite beds are confined to the lower member. (See further discussion of St. Louis Limestone evaporites in the Evolutionary Paleoecology section). 


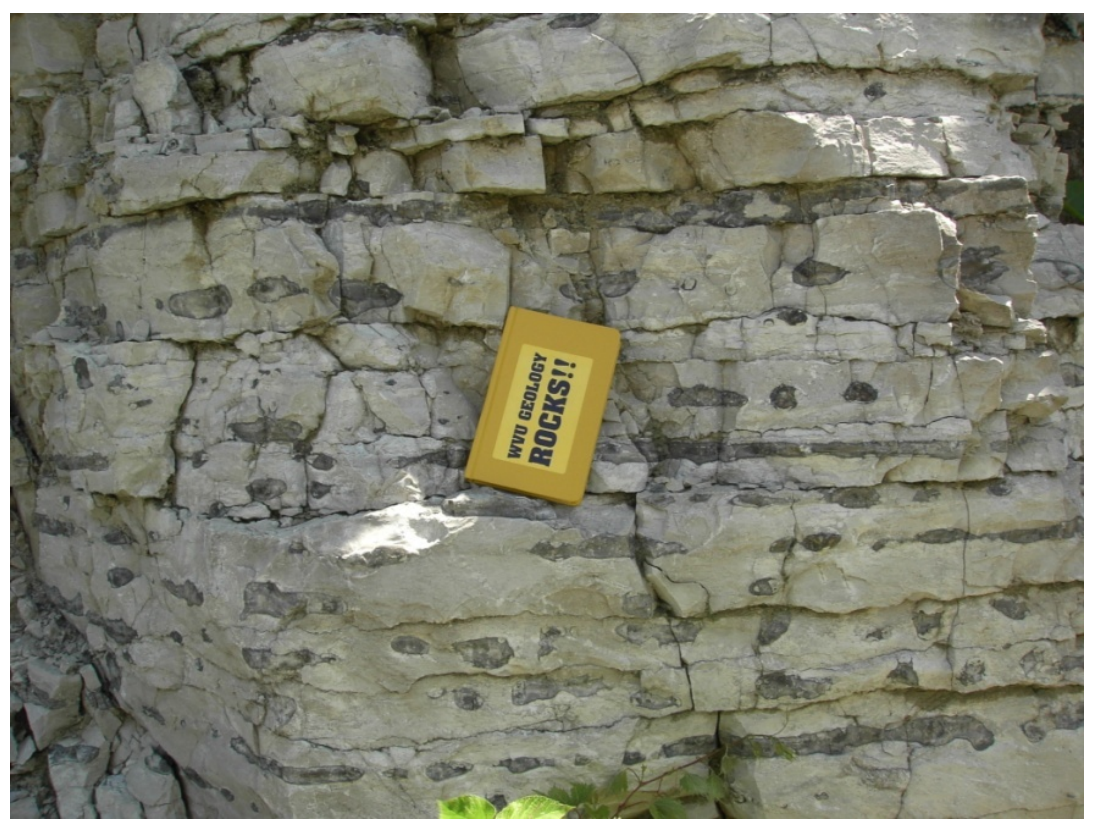

Figure 8. Chert Nodules in upper layers of St. Louis Limestone, Harris Stone Quarry, Bainbridge, Indiana.

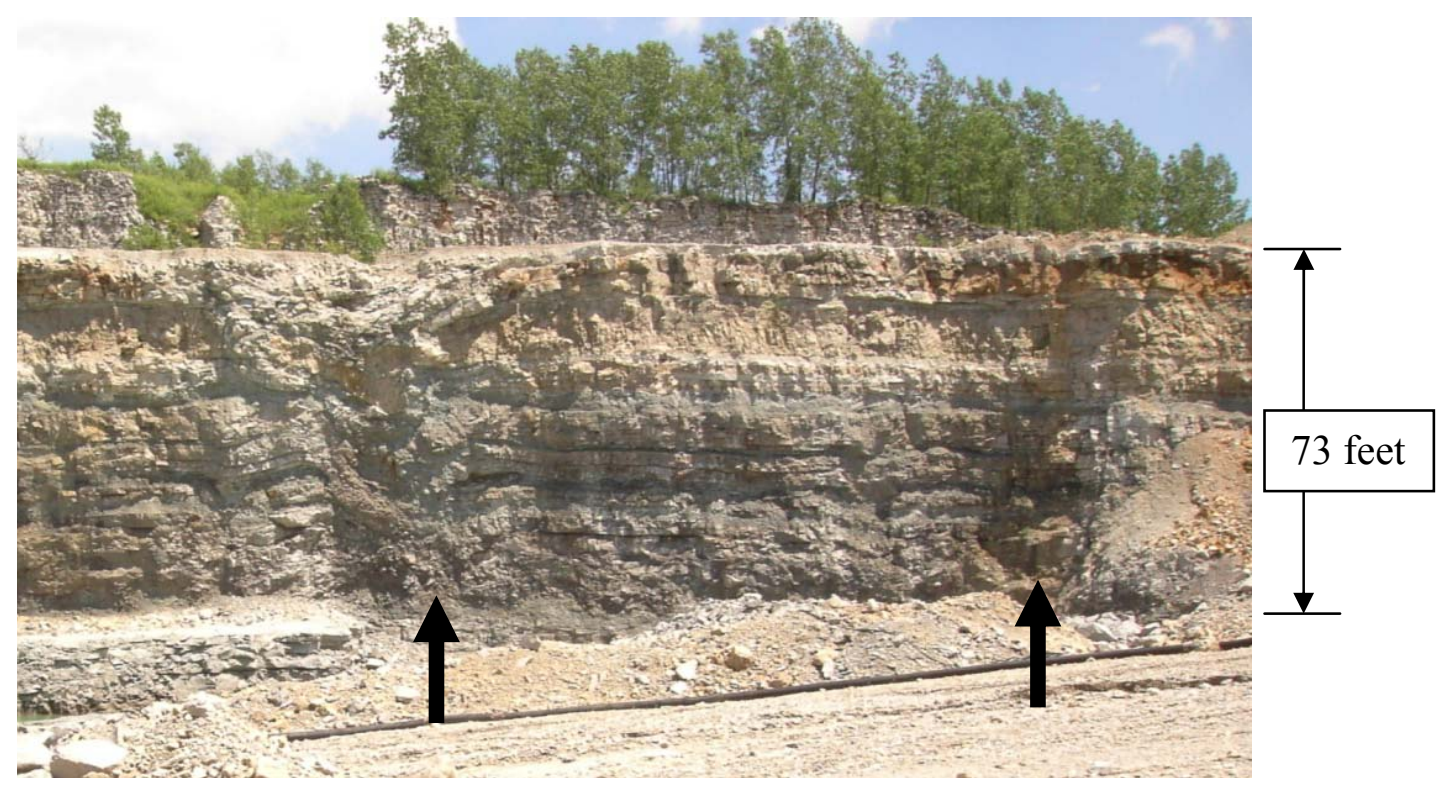

Figure 9. Collapse breccias, St. Louis Limestone, Harris Stone Quarry, Bainbridge, Indiana. 

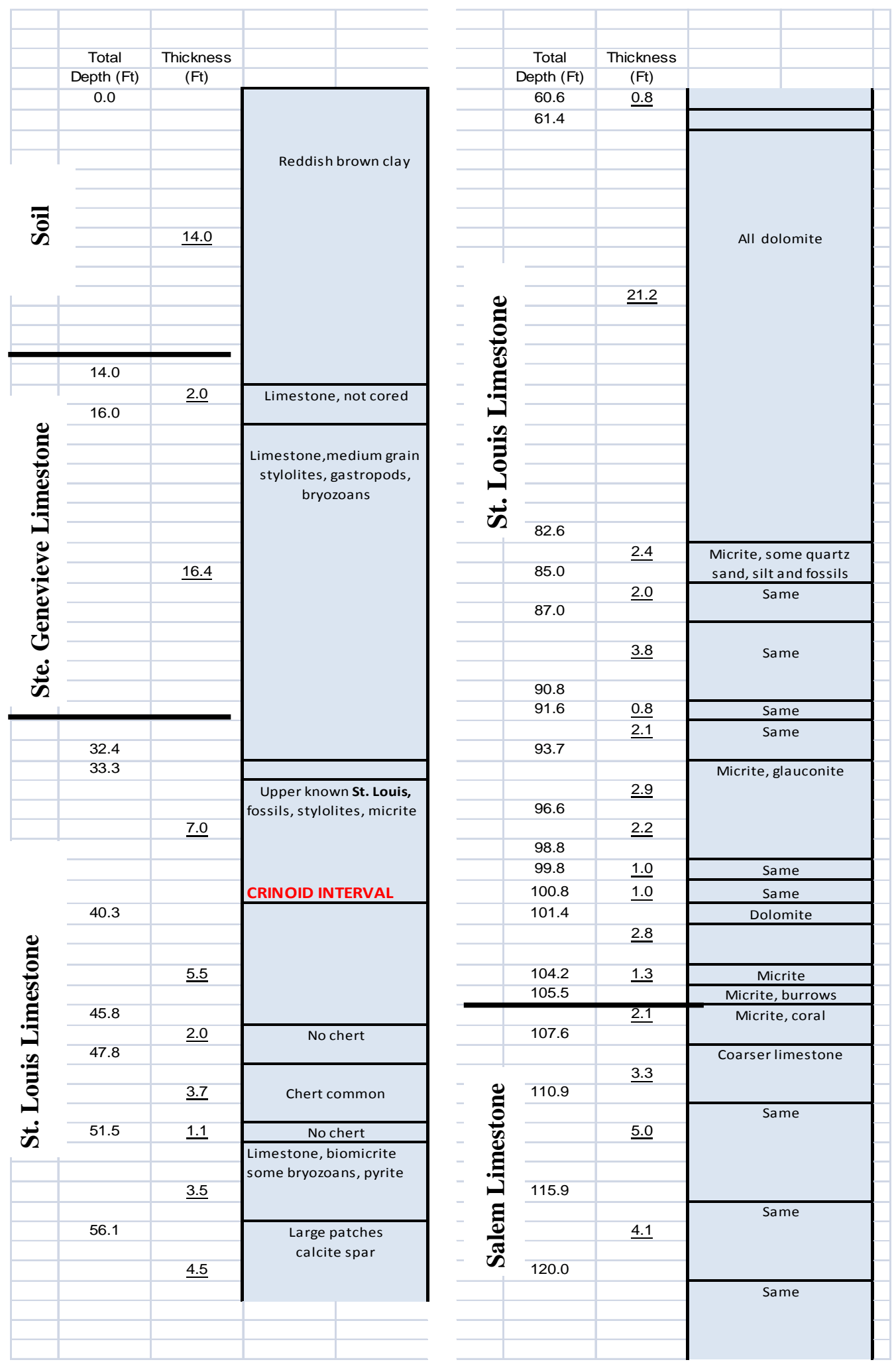

Figure 10. Stratigraphic column, Harris Stone Quarry, Bainbridge, Indiana. (Data from Survey Drill Hole 265, Harris Stone Services, described by R.C. Moore, 1976). 

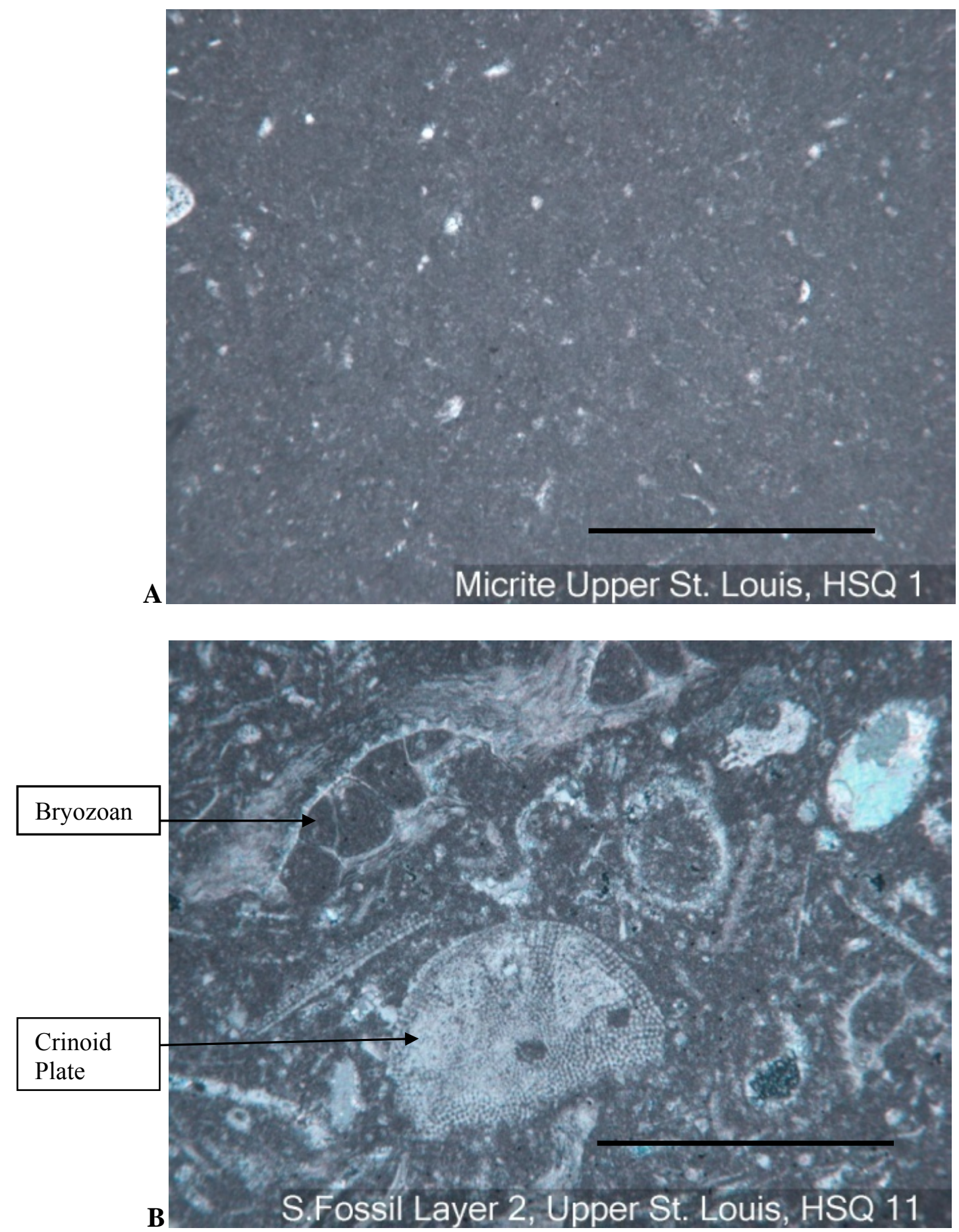

Figure 11. St. Louis Limestone photomicrographs from Harris Stone Quarry, Putnam County, Indiana. The $\underline{\mathbf{A}}$ specimen is from the upper St. Louis and is almost entirely micrite with scattered quartz crystals. The $\underline{\mathbf{B}}$ specimen exhibits bryozoan and crinoid debris. Note the large amount of micrite. Scale Bar $=$ One millimeter. 

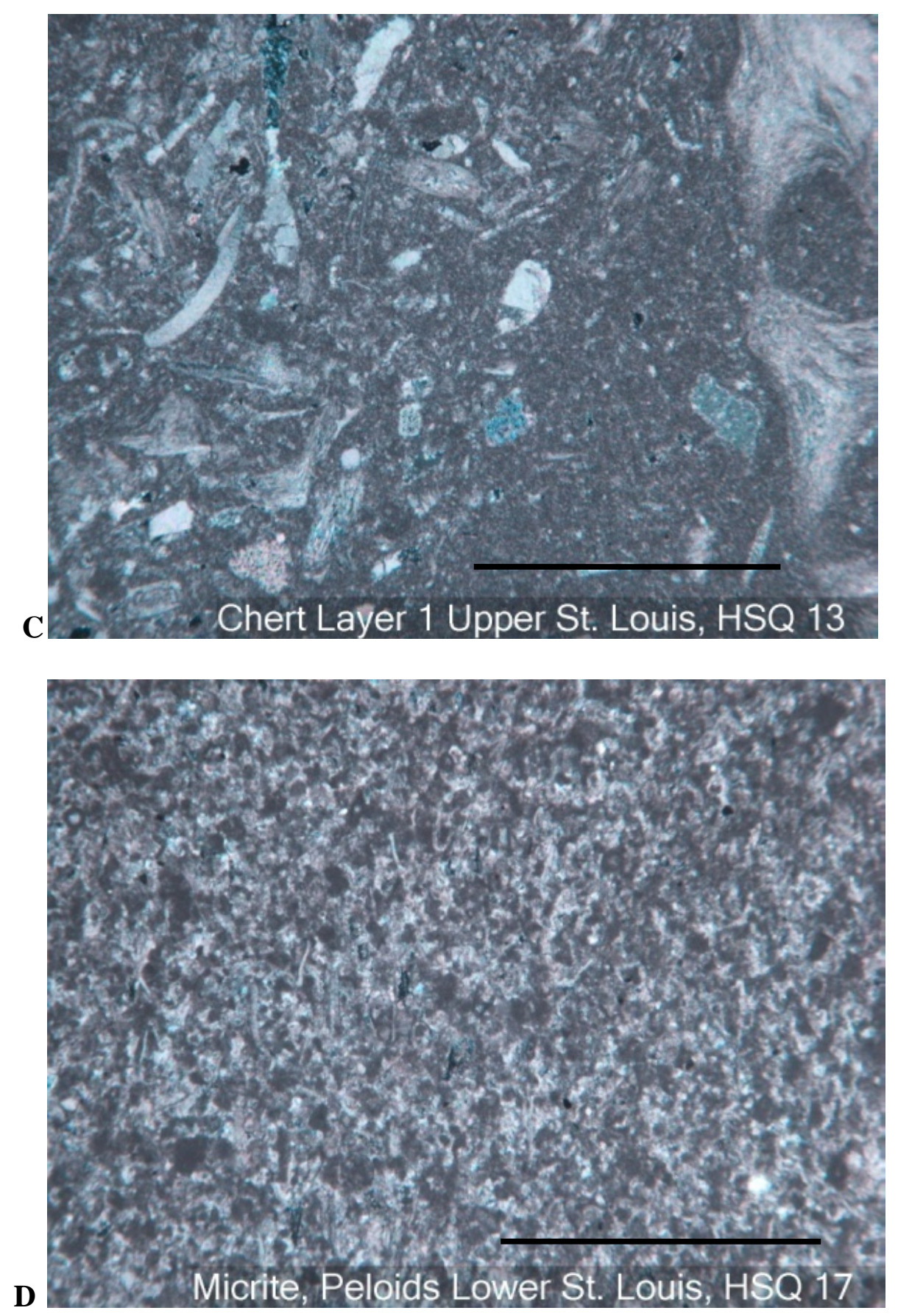

Figure 11(continued). St. Louis Limestone photomicrographs from Harris Stone Quarry,

Putnam County, Indiana. The $\underline{\mathbf{C}}$ specimen demonstrates a large amount of skeletal debris with large amounts of micrite. The $\underline{\mathbf{D}}$ specimen from the lower St. Louis is comprised almost entirely of micrite and peloids. Scale bar = One millimeter 


\section{THICKNESS AND EXTENT}

The thickness of the St. Louis Limestone in Indiana varies from 70 feet in Putnam County (Harris Stone Quarry, Figure 10) to 400 feet in the subsurface of southwestern Indiana. In Illinois the thickness reaches 450 feet in the southeast subsurface, but the formation is removed by erosional truncation to the north in the state (Atherton and Palmer, 1979; Droste and Carpenter, 1990). Like the Salem Limestone, the St. Louis Limestone extends across the entire Illinois Basin and beyond.

The contact between the Salem Limestone and the St. Louis Limestone is difficult to distinguish. Collinson et al. (1979) placed the boundary "at the base of the abundant chert zone" (not to be confused with the Lost River Chert adjacent to the St. Louis/Ste. Genevieve boundary). Dodd (1987) pointed out that a shale layer occurs at the boundary and also mentioned that the lowest occurrence of stromatolites which occur in the St. Louis could mark the boundary. Generally, the occurrence of evaporite, mudcracks, and birdseye structures provides the definitive characteristics distinguishing the St. Louis Limestone from the Salem Limestone. As for the upper boundary of the Meramecian, which coincides with the upper boundary of the St. Louis, most researchers accept Rexroad's (1990) designation of an abrupt change in conodonts from Synclydognathus geminus (upper St. Louis) to Hindeodus cristulus (lower Ste. Genevieve). That same boundary also corresponds to the upper limit of the Lost River Chert Bed which provides a key marker that can be readily seen in the field (Lasemi and Norby, 1999). 


\section{DEPOSITIONAL ENVIRONMENT}

According to Treworgy (1990, p. 130), the St. Louis Limestone was deposited in a "shallow subtidal, highly restricted environment analogous to the modern Florida Bay." Martorana (1987, p. 28) simply stated the St. Louis Limestone "was deposited in a restricted lagoonal intertidal to shallow subtidal environment." Niether author described what they menat by "restricted." Carr et al. (1986), Martorana (1987), and Hattin and Dodd (1992) described 18 evaporite cycles through the St. Louis Limestone in southwest Indiana, that represent, from base to top, intertidal, subtidal, open-lagoon, intertidal, and supratidal-sabkha or restricted lagoon facies. They also list exposed rocks, including limestones, dolostones, grainstones, packstones, and mudstones. Carr et al., (1986) reported rocks with skeletal fragments, pellets, and intraclasts dominating. Other findings include cryptalgal features, burrows, desiccation structures, birdseye and crosslamination structures along with chert and shales. Their interpretation involved varying depositional environments from open-marine shelf to supratidal.

Collinson et al. (1988) agreed with the variety of lithologies listed by Hattin and Dodd (1992). They interpreted that the cherty limestone and mudstone were formed in deeper areas, whereas the "algal mats, lime mudbanks, gypsum and bryozoan-crinoid carbonates represent deposits from the shallow supratidal, intertidal, and subtidal environments, respectively, along the margins of the basin." 
Lasemi and Norby's (1999) interpretation is more in line with the author's concept of upper and lower members of the St. Louis Limestone. The lower St. Louis Limestone is comprised of brown carbonaceous limestone along with units of gypsum, anhydrite and shale which were deposited in a restricted circulation environment. The upper member of micritic, pelletal and skeletal limestone is a result of a more open marine environment. Lasemi and Norby (1999) also pointed out a distinct conodont break that marks the boundary between the two. The lower member is marked by Apatonathus scalenus and the upper by Cavusgnathus. The disappearence of the latter conodont marks the St. Louis/Ste. Genevieve boundary.

\section{STE. GENEVIEVE LIMESTONE}

\section{DESIGNATION}

The Ste. Genevieve Limestone's type locality is a bluff on the Mississippi River south of Ste. Genevieve, Missouri. It was named by B. F. Shumard in 1860 by dividing the previously named St. Louis into two formations and re-naming the upper half the Ste. Genevieve Limestone. That designation was not accepted, however, until E.O. Ulrich proposed it for Illinois in 1905. In 1922, E. R. Cumings agreed to use the name in Indiana. As noted above, considerable controversy has continued as to the proper location of the contact point between the St. Louis and the Ste. Genevieve. It is bounded by the St. Louis Limestone below and the Paoli Limestone above in Indiana. Illinois designates the formation above the Ste. Genevieve to be the Aux Vases Sandstone. In southeastern 
Illinois a layer dominated by dolomitic limestone and dolomite exists within the upper Ste. Genevieve Limestone and below Aux Vases Sandstone, that was designated as the Joppa Member of the Ste. Genevieve, (Keroher, 1966; Atherton and Palmer, 1979;

Rexroad, 1986).

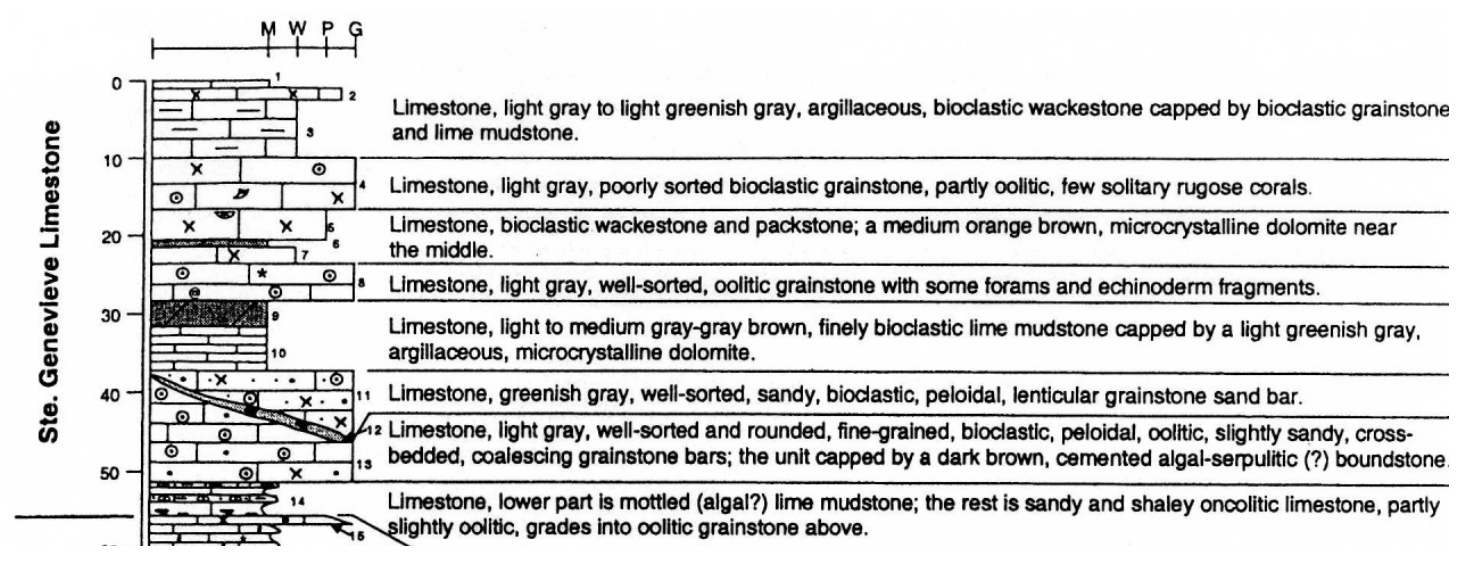

Figure 12. Stratigraphic column of the Ste. Genevieve Limestone, Casper Stolle Quarry, south of Alton, Illinois. Scale in feet. See key to symbols, Appendix A (Lasemi et al., 1999).

\section{LITHOLOGY}

Within Indiana the Ste. Genevieve Limestone is comprised of oolitic, skeletal, micritic and detrital limestone (Figure 13). It also contains shale, dolomite, sandstone and chert (Carr, et al., 1986). In western Illinois it is comprised of clean, oolitic grainstone with some beds of fossiliferous shaley limestone, dolomite, lime mudstone and bioclastic grainstone (Lasemi and Norby, 1999) (Figure 12). At the Harris Stone Quarry it is described as microcrystalline to medium grained with stylolitic laminations. Illinois divides the Ste. Genevieve Limestone into three or four members, depending on the 
location. The Joppa Member in southeastern Illinois is composed of limestone, dolomite, sandstone and shale (Atherton and Palmer, 1979). The Karnak Limestone Member is 3 to 12 meters thick, wedging out about midway across southern Illinois. It is entirely composed of limestone with some ooids (Bristol and Howard, 1976; Atherton and Palmer, 1979). Another member, the Spar Mountain Sandstone, is silt and sandy silt. Toward the north the sand grains are coarser and better rounded. The upper member is designated the Fredonia Limestone Member, is 24-30 meters thick and thins out to the north. It is light grey, crossbedded and contains ooids and crinoidal skeletal fragments.

The Ste. Genevieve Limestone in the western Illinois Basin was described more generally by Martorana (1987) as "a dense, highly bioturbated, crinoid-bryozoan wackestone to mudstone which is interbedded with lenticular carbonate sand bodies called McClosky Sands.” McClosky Sands are ooid grainstones. Chert is included as part of the lithology in most descriptions by workers before 1987. It is probable that they were describing the lithology prior to the re-designation of the St. Louis/Ste. Genevieve boundary by Maples and Waters (1987). In that case, the chert beds may have been the Lost River Chert which is now assigned to the St. Louis Limestone. 

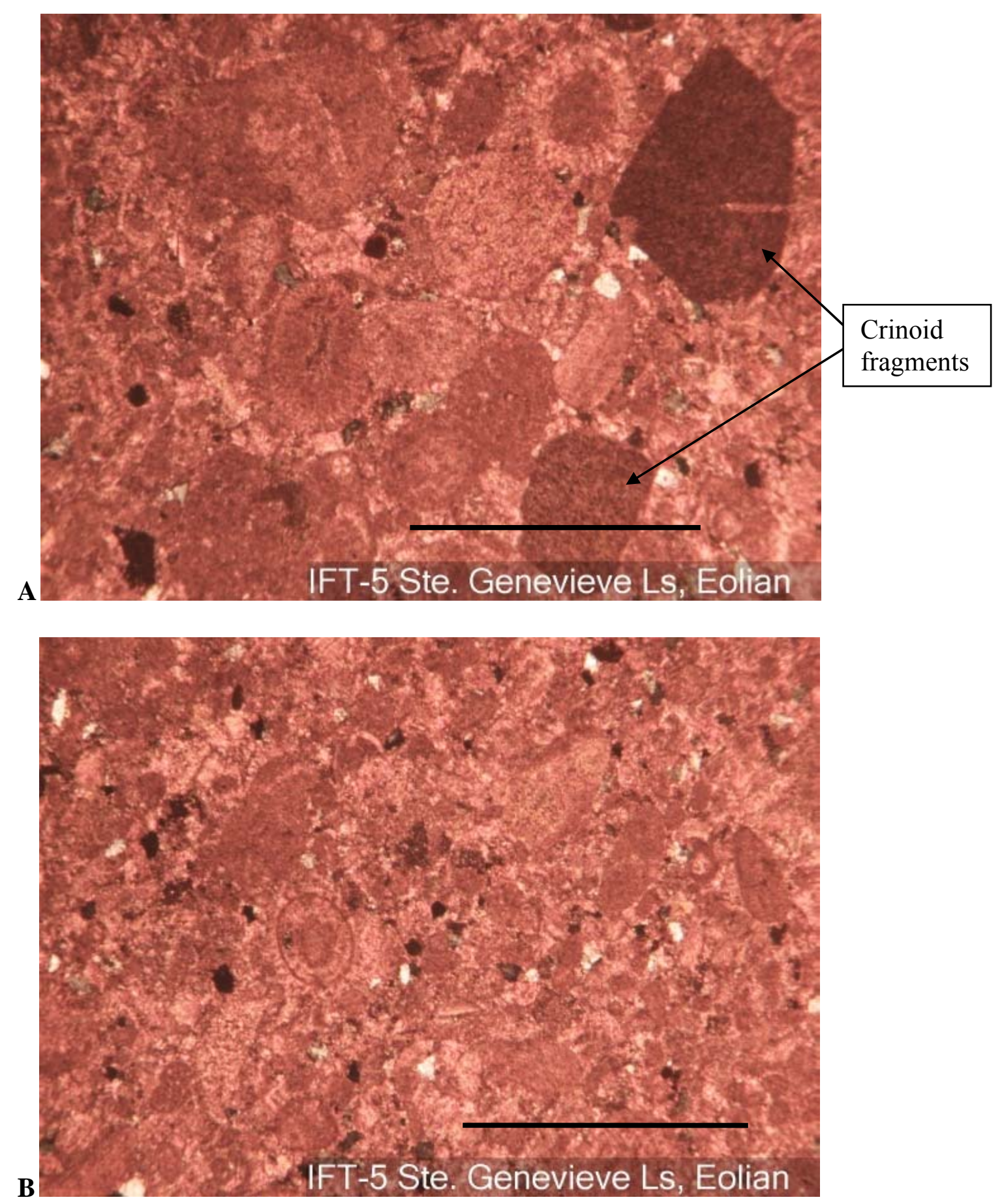

Figure 13. Ste. Genevieve Limestone photomicrographs. Scale bar $=$ One millimeter

$\underline{\mathbf{A}}$ and $\underline{\mathbf{B}}$ are from 3 miles south of Corydon, Indiana. 


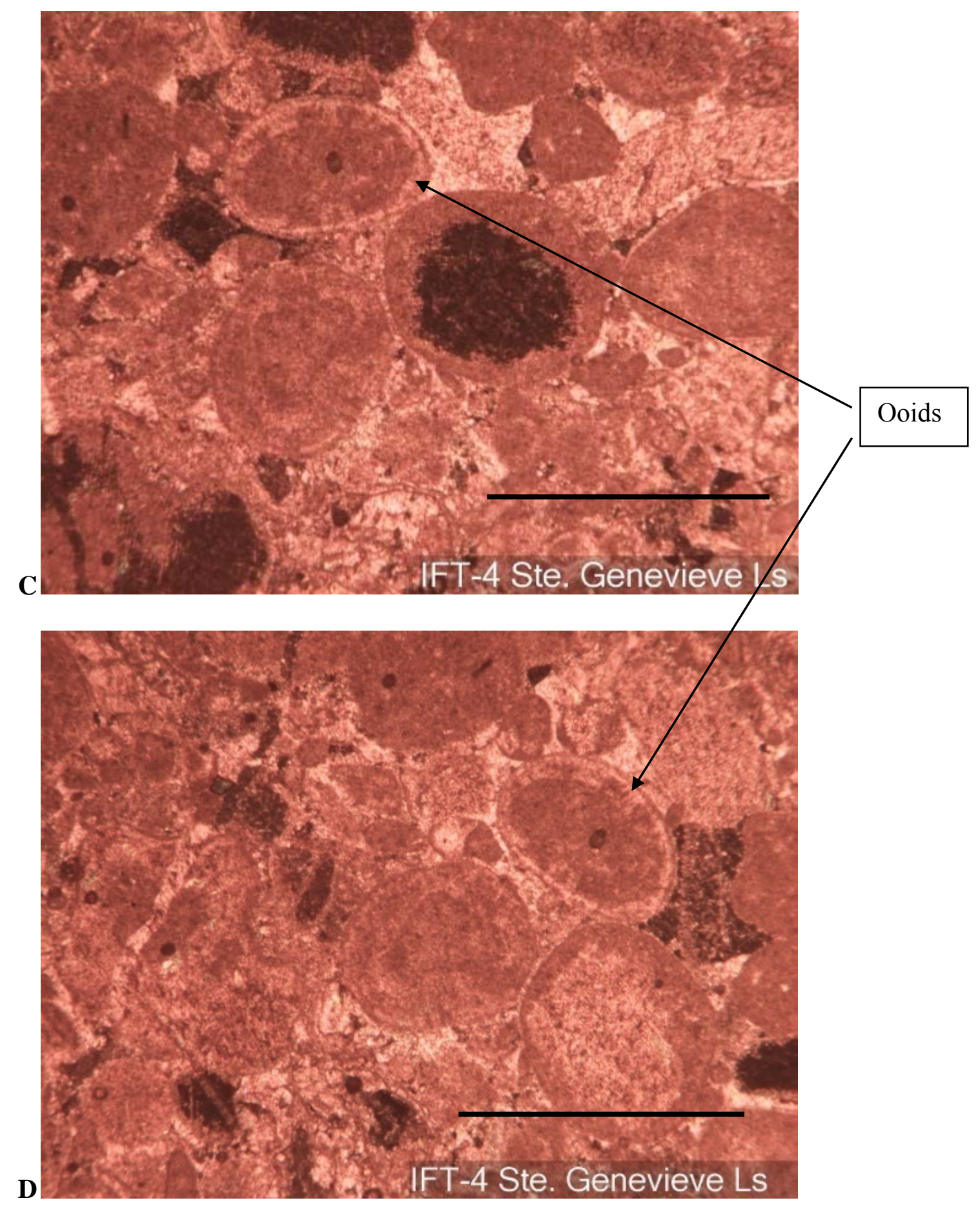

Figure 13 (continued). Ste. Genevieve Limestone photomicrographs. Scale bar $=$ One millimeter $\underline{\mathbf{C}}$ and $\underline{\mathbf{D}}$ are from Harrison County, Indiana, 3 miles north of the Ohio River. Note the dominance of ooids in all of the specimens. Crinoid fragments are in the $\underline{\mathbf{A}}$ and $\underline{\text { D }}$ specimens. These are relatively free of micrite. Scale bars=One millimeter. Stained with Alizarin red 


\section{THICKNESS AND EXTENT}

In Indiana, the Ste. Genevieve varies in thickness from 45 to 220 feet (14-76 meters). It is thinnest in the north and thickens southwestward. At the Harris Stone Quarry core measurements indicates a thickness of 16-18 feet (5-6 meters). Modern soil overlies the Ste. Genevieve, with the upper part eroded away. In Illinois thicknesses of the Ste. Genevieve range from 270 feet (91 meters) in the south to 90 feet (30 meters) in the north and west. The lateral extent is over the full area of the Illinois Basin and beyond as with the St. Louis and Salem Limestones.

\section{DEPOSITIONAL ENVIRONMENT}

The Ste. Genevieve Limestone exhibits successions of mudstone and grainstone. It differs from the St. Louis and Salem limestones, however, in that it has a preponderance of oolitic limestone, indicating a higher energy, hypersaline, shallow, warm environment. The mudstone was formed in deeper water around the oolite shoals (Collinson et al., 1988). The environment of the Ste. Genevieve was similar to the Salem Limestone, but the oolitic sand bodies in the Ste. Genevieve were more concentrated and migrated over smaller distances (Treworgy, 1990). Hattin and Dodd (1992) explained that mudstone and wackestone of the Ste. Genevieve were "probably deposited in a lagoon or intershoal area of the shallow Ste. Genevieve sea.” Martorana (1992, p.29) explained that toward the edges of the basin a more shallow low energy shallow marine environment was in place. Sediment from that shallow, subtidal area was deposited in a high energy shoal environment resulting in oolitic grainstone formation as "high energy marine bars" 
In southern Indiana, eolian origins for parts of the Ste. Genevieve have been postulated; varve-like cross-beds, dunes, and brecciation were described by Hattin and Dodd (1992). These authors observed dunes, herringbone cross-bedding and large cross-beds. Obvious body fossils were rare, and skeletal grains were very small. Smith et al. (2001) summarized findings that indicate these grains are eolian in origin. These indicators include very fine sand grains, inverse grading, high degree of sorting within lamina, broken and abraded ooids, frosted quartz grains, lack of burrows, and presence of barchan dune forms. In addition paleosols and rhizoliths (rootforms) occur, indicating subaerial exposure. Dodd et al. (2001) identified four stratigraphic units of eolian grainstones in the Ste. Genevieve of southern Indiana. These reflect four cycles in relative sea level change that resulted in eolian dunes. Overall, they considered the Ste. Genevieve to have formed in open, well agitated water at about 10 degrees south latitude. Eolianites are present in southern Indiana and become less and less apparent toward the north in the Illinois Basin.

A thick dense layer of crinoidal fossil debris occurs in the Ste. Genevieve of southern Indiana. This was interpreted by Smith et al. (1999) as being formed in a moderate- to high-energy environment evidenced by the lack of mud, coarse grain size and abundance of echinoderms. The overall facies is characterized by Smith et al. (1999) to be a carbonate ramp. The complete depositional environment includes skeletal grainstone between topographic highs capped with ooid shoals. Mudstone and crinoids were localized in the low-energy lagoonal areas between the shoals and in the offshore subtidal 
areas. The crinoids, requiring normal salinity, were more likely in the open marine setting (Smith and Read, 1999). 


\section{Thickness and Extent of Formations within the study area}

The variation in combined thickness of the Salem, St. Louis and Ste. Genevieve limestones across the Illinois Basin is from 940 feet in the deepest part to zero at its edges. Figures 14, 15 and 16 illustrate the variation in thickness across the Illinois Basin based on core drillings. Those thickenesses are a function of erosion and subsidence.

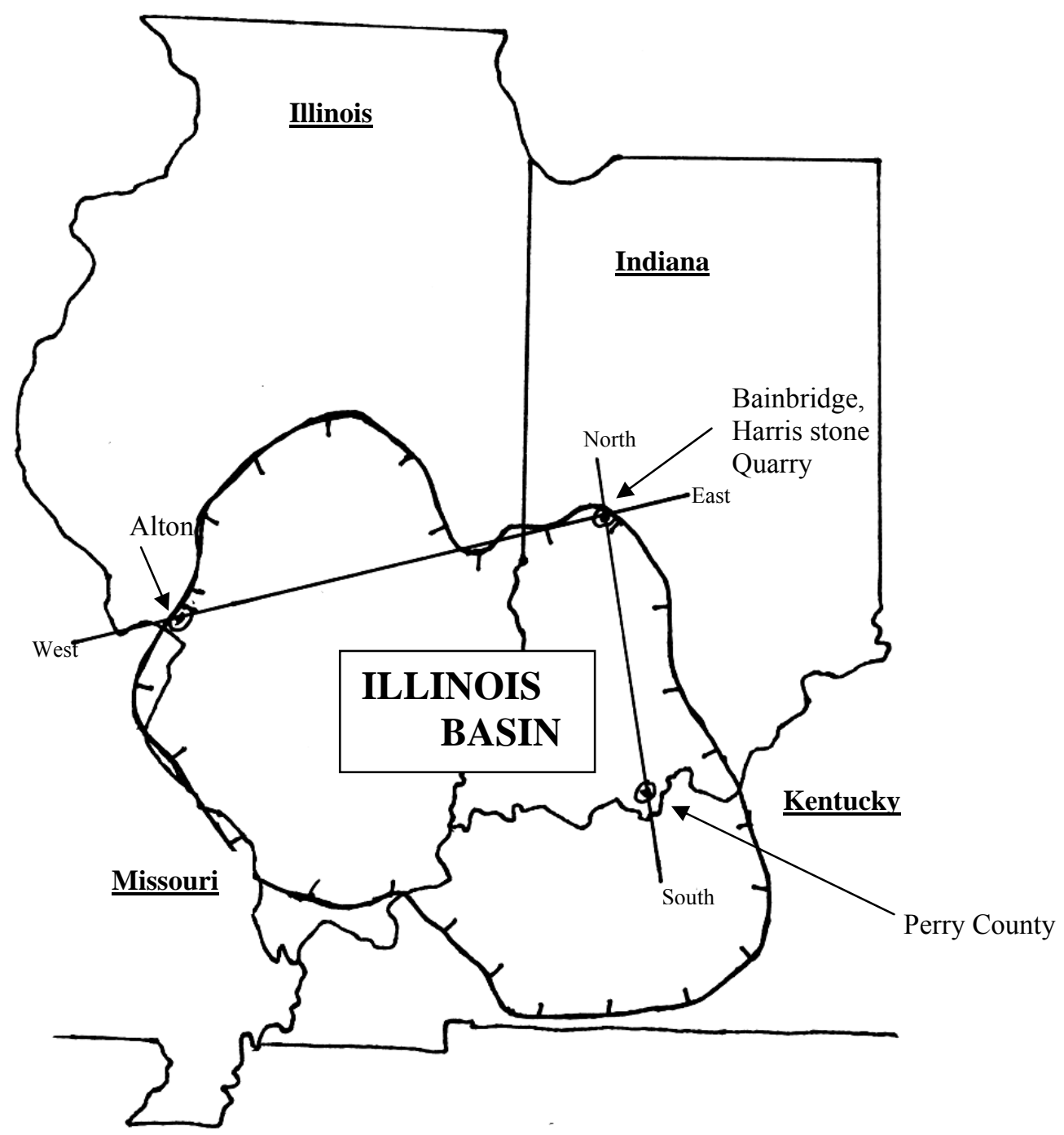

Figure 14. Thickness cross-sections reference map.The hachured line represents the Illinois Basin of the Kaskaskia II subsequence within the eroded limit of the Chesterian Series. The north-south and the west-east cross-section thickeness are shown in Figures 15 and 16. 
WEST

EAST

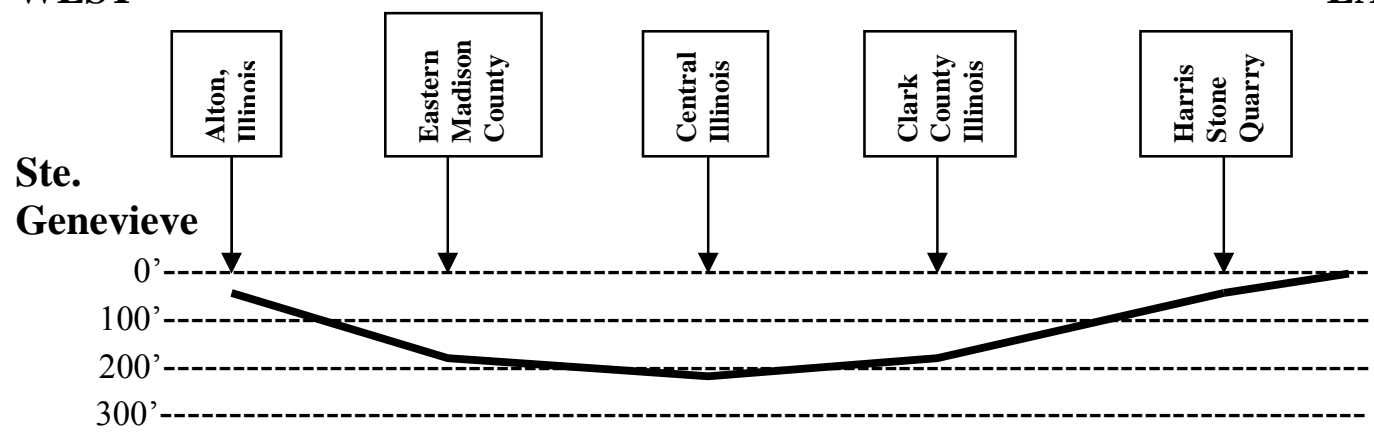

\section{St. Louis}

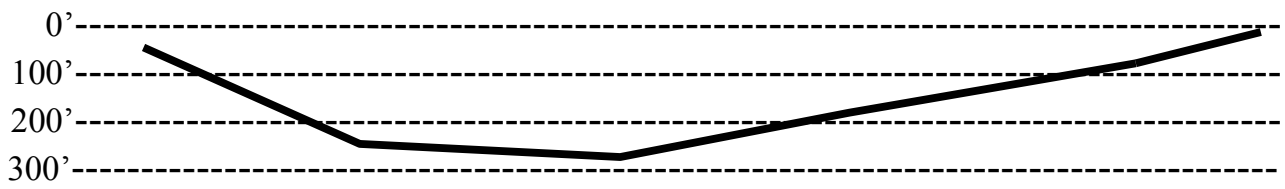

\section{Salem}

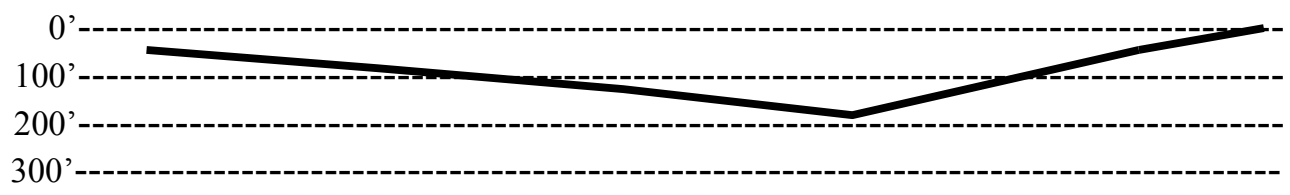

\section{Total for}

All Three

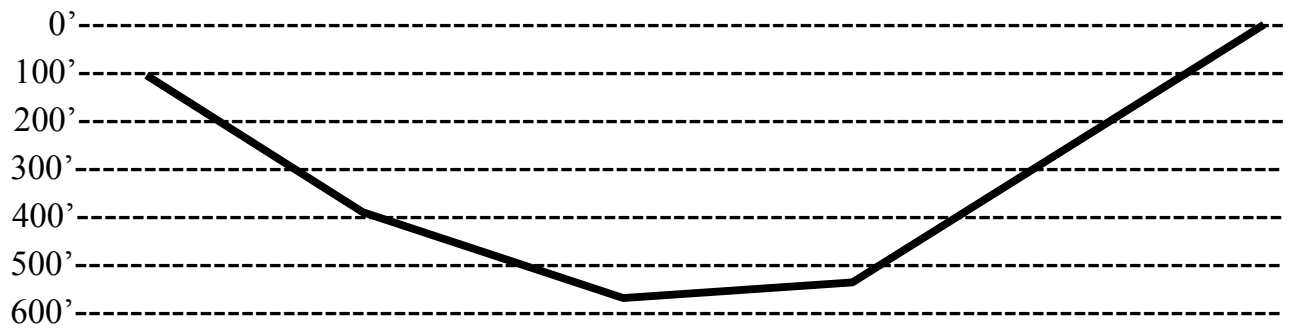

Figure 15. East-west thickness of the Salem, St. Louis and Ste. Genevieve Limestone formations from Alton, Illinois, to the Harris Stone Quarry, Bainbridge, Indiana.

(These thicknesses are a compilation from the following sources: Harris, 1976;

Treworgy, 1990; Treworgy and Devera, 1990; Lasemi and Norby, 1999; Keith and Thompson, 2005). 
SOUTH

Ste. Genevieve

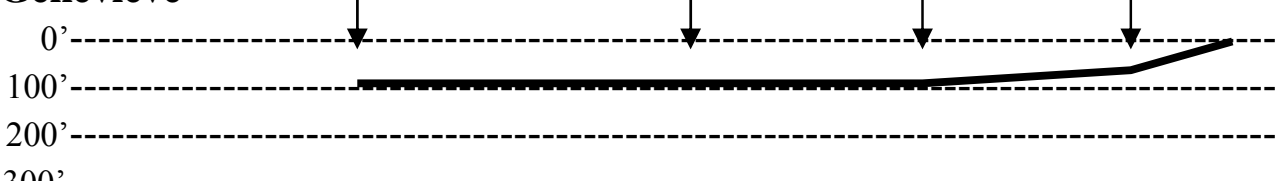

\section{St. Louis}

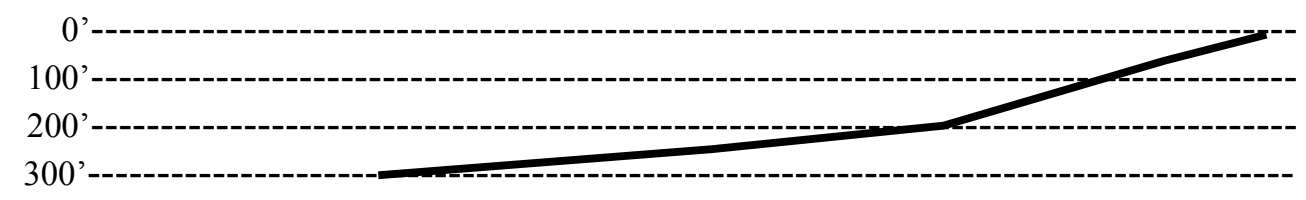

\section{Salem}

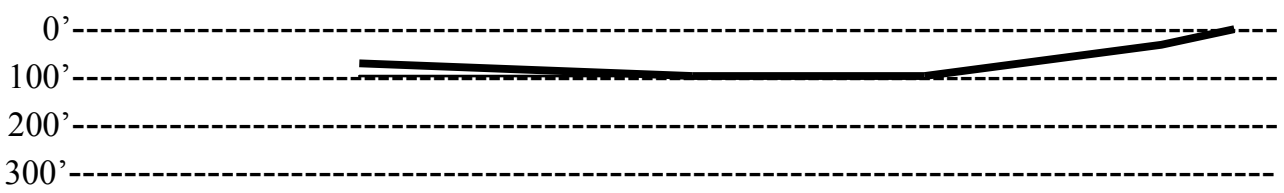

\section{Total for}

All Three

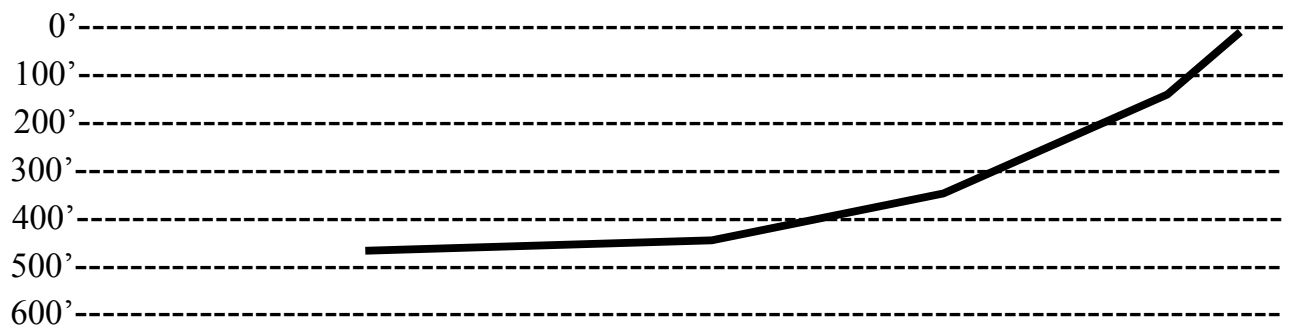

Figure 16. North-south thickness of the Salem, St. Louis and Ste. Genevieve Limestone formations from Perry County to the Harris Stone Quarry, Bainbridge, Indiana. (These thicknesses are a compilation from the following sources: Harris, 1976; Droste and Carpenter, 1990; Keith, 2005). No measured stratigraphy columns were found representing further south on that line into Kentucky. 


\section{Summary}

Differing sequences of lithologies occur in the Salem, St. Louis and Ste. Genevieve limestones. The Salem Limestone originated in a high energy environment with shoalingupward cycles that resulted mainly in grainstone containing a large variety of skeletal grains, ooids, and minor mudstone. The lower St. Louis Limestone formed in a much lower-energy environment, in lagoonal and sabka-like conditions. As a result, large amounts of mudstone (micrite) were formed along with the characteristic sabka evaporites, and dolomite. The upper St. Louis developed in a more open setting, resulting in almost entirely carbonate mudstone with at least one distinct layer of fossils. The Ste. Genevieve Limestone is dominated by oolite indicating a shallow, warm, and high energy environment. It exhibits the full range of subtidal, intertidal and supratidal facies with some mudstone as well as eolian structures. This transition through the different environments of these three formations may be a contributing factor in the evolutionary history of the crinoid faunas in these rocks. 


\section{Systematics}

\section{Introduction}

A modern systematic study of St. Louis Limestone crinoids is lacking, as the primary work was done in the $19^{\text {th }}$ century. More recent studies may be lacking, in part, because of previous confusion regarding the stratigraphic boundary with the overlying Ste. Genevieve Limestone, which lead to uncertainty as to the correct formation assignment of museum specimens. Consequently, some crinoid species listed as being from the St. Louis Limestone are suspect as they may actually be from the Ste. Genevieve Limestone. This is because the St. Louis Group of Worthen (1866) included rocks of Shumard's (1860) Ste. Genevieve Limestone, a name that was suppressed until Ulrich $(1904,1905)$ separated it from the St. Louis Limestone. Thus, the provenance of the St. Louis crinoids collected during the $19^{\text {th }}$ Century was uncertain. This uncertainty limits our understanding of Meramecian crinoid faunas and their patterns of evolutionary change. It also limits our understanding of the crinoid paleoecology of the St. Louis Limestone as compared to the underlying and overlying carbonate formations.

The complexities of the naming and boundaries were described in the geologic setting section earlier in this work. For this study, crinoids from the St. Louis Limestone are only from the Illinois Basin. The St. Louis Limestone exists either by the same name or an equivalent-age formation outside the Illinois Basin. Except for corroborative information, crinoids from those areas outside the Illinois Basin will not be considered. The St. Louis Limestone is exposed around the rim of the Illinois Basin, where it outcrops through 
southwest Indiana, western Kentucky, eastern Missouri, and southern Illinois. Most of the crinoids studied from the Field Museum of Natural History and the United States National Museum of Natural History, Springer Collection, are from the western side of the Illinois Basin around Alton, Illinois(Figure 17). The Harris Stone Quarry (Robert Howell's collection site) is located at Bainbridge, Indiana, on the northeastern edge of the basin (Figure 17).

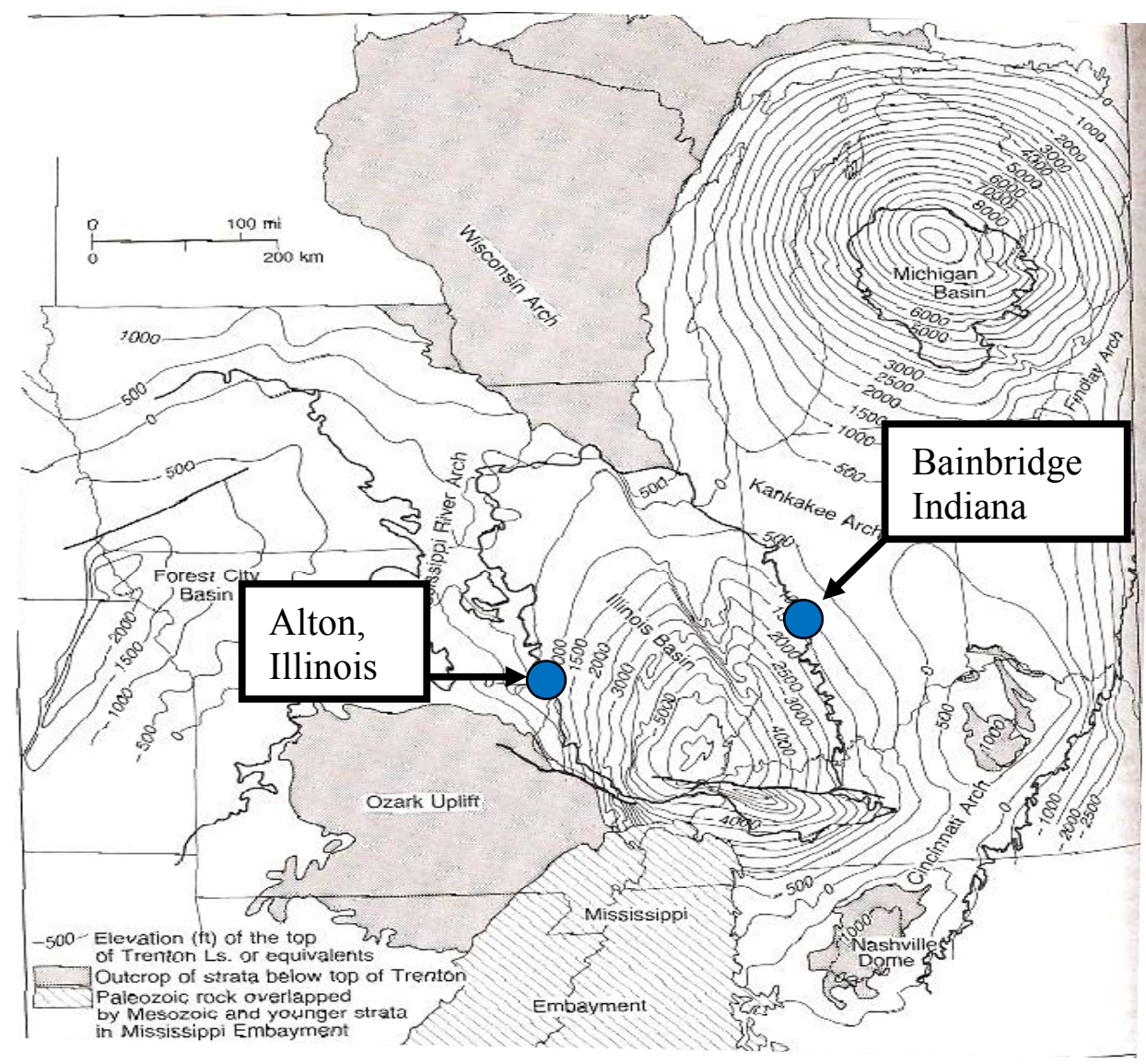

Figure 17. The Illinois Basin. Note Alton, Illinois, to the west and Bainbridge, Indiana, to the east (Adapted from Sloss (1988). 


\section{Methods}

With the boundaries of the St. Louis Limestone clearly established, a modern evaluation of the crinoids within that formation can be made. This is also facilitated by the availability of a collection of crinoids made by Robert Howell from a confirmed St. Louis Limestone locality, the Harris Stone Quarry, Bainbridge, Indiana (UTM, Datum WGS84, Zone 16, 513530mE 4399427mN); (Figure 17). The Harris Stone Quarry was cored in 1976 (Figure 10) providing data confirming the Ste. Genevieve Limestone above the St. Louis and the Salem Limestone below (Moore, 1976). Another core was obtained by Keith and Thompson (2005) just south of Bainbridge (UTM, Datum WGS84, Zone 16, 526544mE 4349926mN); (Appendix C), confirming the stratigraphy. Dr. Kammer and this author visited the quarry with Robert Howell in June, 2008. Mr. Howell pointed out the specific bed in the upper part of the St. Louis Limestone from which he collected all of the crinoids now at the Indiana State Museum, Indianapolis, Indiana (Appendix B). Howell's collection serves as a reference collection for those species definitely known to be from the St. Louis Limestone. 


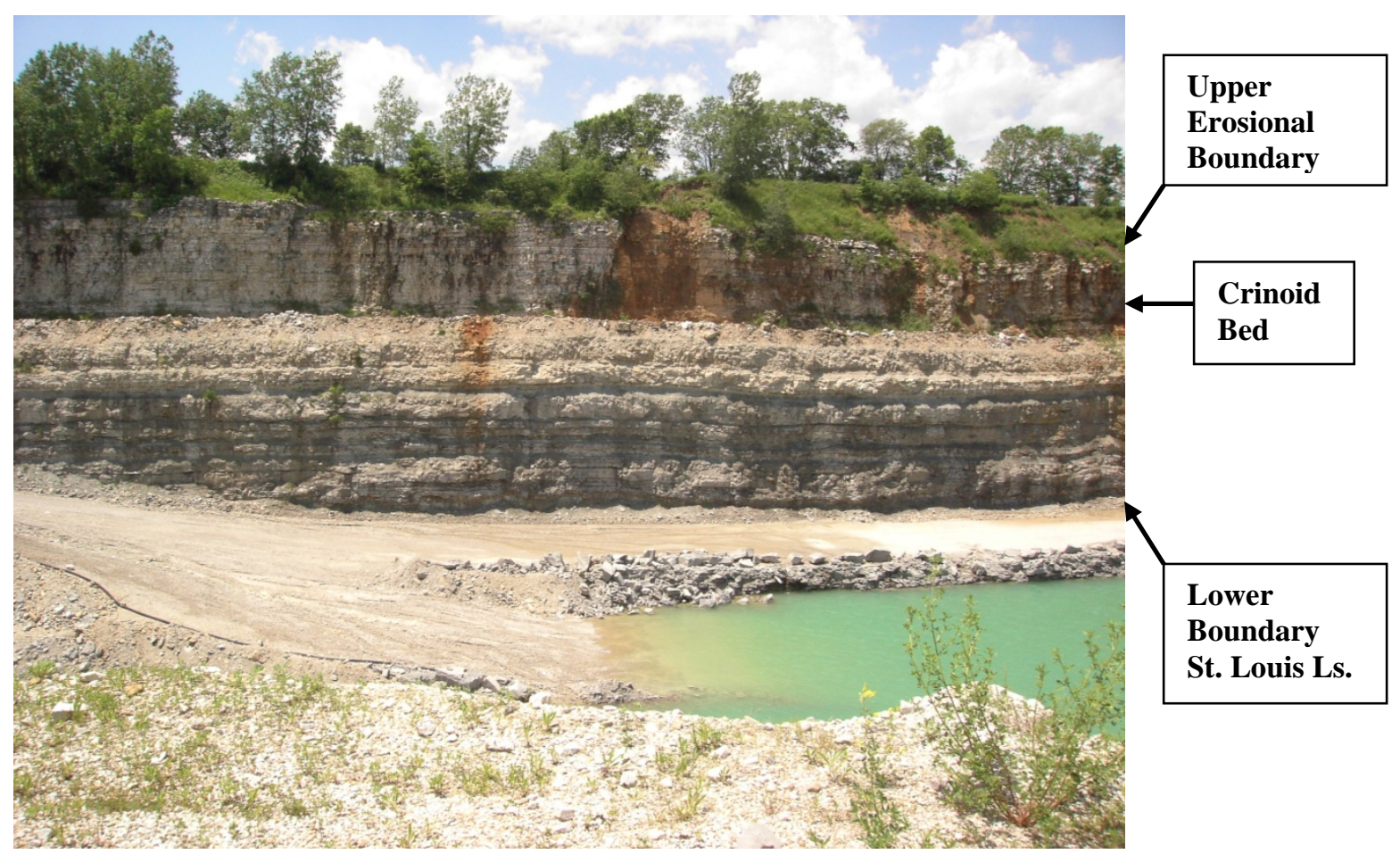

Figure 18. The Harris Stone Quarry, Bainbridge, Indiana. The vegetation level at the top marks the upper boundary of the St. Louis Limestone. The base of the outcrop above the quarry floor marks the lower boundary of the St. Louis Limestone. The layer marked as "crinoid bed" is the level from which the crinoids were collected at this site. The distance between the upper and lower boundary of the St. Louis Limestone is 73 feet.

Not all St. Louis crinoid species will necessarily be represented in the collection made by Robert Howell. Two possible reasons must be considered. One, not all fossils from the quarry site are likely to have been found and included among the collected specimens. Two, other species probably existed elsewhere in the St. Louis Limestone that are simply not present at the quarry site. In order to at least partially compensate for those sources of error, crinoids that had been assigned to the St. Louis Limestone contained within the 
Springer Collection in the United States National Museum of Natural History Museum, Washington, D.C., and the Field Museum of Natural History, Chicago, Illinois, were evaluated (Appendices C and D). In addition, the literature was reviewed for any crinoid species that had been historically assigned to the St. Louis. The listings were evaluated individually using modern stratigraphic and taxonomic considerations to improve their accuracy.

The final concern is the accuracy of the taxonomic assignment of crinoids reported from the St. Louis Limestone. Specimens of the same species were assigned to different species and given separate names by various authors and should be synonymized. Some generic assignments needed to be modernized. Other species do not have available type specimens, photographs or drawings to confirm their identification. These problems have been addressed in light of modern taxonomic practices.

Specimens were also evaluated from the bounding Salem and Ste. Genevieve limestones. The purpose of this was to assess evolutionary changes during the St. Louis time frame. Specimens of those species were from the Springer Collection and the Field Museum, plus the literature. 


\section{Faunal Analysis}

An initial list of crinoids reported from the St. Louis Limestone was compiled from available indexes (Grabau and Shimer, 1910; Bassler and Moodey, 1943; Webster, 2003). Evaluation of morphologies from actual specimens, photographs and drawings was done using the methods outlined by Lewis and Donovan (2007) and Fearnhead (2008).

Five categories of results were derived from the analysis: 1 . Crinoids previously identified as St. Louis and not otherwise re-designated are continued. 2. Crinoids previously identified, but not included in the St. Louis Limestone were added. 3. A new species was identified. 4 . Some separately named crinoids were actually the same species as others in the St. Louis and were synonymized. 5. Crinoid species that were rejected as being from the St. Louis according to modern standards (Table 3).

The Systematic Paleontology in the following section reviews each of the crinoid species that are reported in the St. Louis. Crinoids in all five categories of table 3 are included. Explanations for inclusion, synonymization or exclusion are provided for crinoids so effected. 


\begin{tabular}{|c|c|}
\hline CATEGORY OF RESULTS & SPECIES \\
\hline \multicolumn{2}{|l|}{$\begin{array}{l}\text { Crinoids retained } \\
\text { from the St. Louis }\end{array}$} \\
\hline & 1. Camptocrinus cirrifer (Wachsmuth and Springer, 1897) \\
\hline & 2. Camptocrinus myelodactylus (Wachsmuth and Springer, 1897) \\
\hline & 3. Hyrtanecrinus ornatus (Wachsmuth and Springer, 1881) \\
\hline & 4. Talarocrinus conigeru, (Shumard, 1857) \\
\hline & 5. Talarocrinus simplex (Shumard, 1857) \\
\hline & 6. Platycrinites niotensis (Meek and Worthen, 1865) \\
\hline & 7. Platycrinites pumilus (Hall, 1860) \\
\hline & 8. Platycrinites sarae (Hall, 1858) \\
\hline & 9. Barycrinus spectabilis ( Meek and Worthen, 1870) \\
\hline & 10. Phacelocrinus dactyliformis (Hall, 1858) \\
\hline & 11. Phacelocrinus vanhornei (Worthen, 1875) \\
\hline & 12. Culmicrinus missouriensis ( Shumard, 1857) \\
\hline & 13. Aphelecrinus scoparius (Hall,1858) \\
\hline \multirow[t]{4}{*}{ (Unconfirmed) } & 14. Pachylocrinus norwoodi (Meek and Worthen, 1865 ) nomen dubium \\
\hline & 15 Cymbiocrinus dactylus (Hall, 1859) \\
\hline & 16. Taxocrinus shumardianus (Hall, 1858) \\
\hline & 17. Onychocrinus magnus ( Worthen, 1875) \\
\hline \multicolumn{2}{|l|}{$\begin{array}{l}\text { Crinoids reported elsewhere } \\
\text { added to St. Louis }\end{array}$} \\
\hline Previously only Keokuk Ls., Osagean & 1. Cribanocrinus coxanus (Worthen, 1882) \\
\hline $\begin{array}{l}\text { Previously Borden Fm \& New Providence } \\
\text { Shale, Osagean }\end{array}$ & 2. Stinocrinus? sp. \\
\hline Previously only Ste. Genevieve, Chesterian & 3. Dinotocrinus salteri (Worthen, 1882) \\
\hline \multicolumn{2}{|l|}{ New species } \\
\hline & 1. Armenocrinus howelli n. sp. \\
\hline \multicolumn{2}{|l|}{ Synonymized } \\
\hline & 1. Cyathocrinites macadamsi (Miller and Gurley, 1895) \\
\hline & TO Cymbiocrinus dactylus (Hall, 1859) \\
\hline & 2. Poteriocrinites arrectarius (Miller and Gurley, 1896) \\
\hline & TO Phacelocrinus vanhornei (Worthen, 1875) \\
\hline & 3. Aphelecrinus peculiaris (Worthen, 1883) \\
\hline & TO Aphelecrinus scolparius (Hall, 1859) \\
\hline \multicolumn{2}{|l|}{$\begin{array}{l}\text { Crinoids incorrectly } \\
\text { listed from St. Louis }\end{array}$} \\
\hline & 1. Talarocrinus sexlobatus (Shumard, 1867) \\
\hline & 2. Amphoracocrinus amphora (Wachsmuth and Springer, 1897) \\
\hline & 3. Azygocrinus(or Batocrinus) euconus (Meek and Worthen, 1865) \\
\hline & 4. Dichocrinus parvulus (Meek and Worthen, 1865) \\
\hline & 5. Platycrinites faberi (Miller, 1889) nomen dubium \\
\hline & 6. Platycrinites huntsvillae (Troost, 1850) \\
\hline & 7. Cyathocrinites globus (Troost, 1850) \\
\hline & 8. Plaxocrinus sanctiludovici (Worthen, 1889) \\
\hline
\end{tabular}

Table 3. Five categories of crinoid analysis: 1. Crinoids retained as St. Louis; 2. Crinoids listed elsewhere added to St. Louis; 3. New species; 4. Synonymized; 5. Crinoids incorrectly listed from St. Louis. 


\section{Systematic Paleontology}

Morphologic terminology follows Ubaghs (1978). Examined material is housed in the following museums and institutions: INSM, Indiana State Museum; FMNH, Field Museum of Natural History; and USNM-S (Springer Collection), United States National Museum of Natural History. Synonymies and occurrences, except as noted, are from Webster (2003).

Class Crinoidea Miller, 1821

Order Cамerata Wachsmuth and Springer, 1885

Suborder Diplobathrida Moore and Laudon, 1943

Superfamily RHODOCRINITACEA Roemer, 1855

Family RHodocrinites Roemer, 1855

Genus Cribanocrinus Kirk, 1944

Type species.--Rhodocrinus wortheni Hall, 1858, p. 556.

Diagnosis.--Crown urn shaped; cup bowl shaped, base flattened, concave for column insertion; infrabasals small, covered by column attachment; basals hexagonal, just slightly larger than radials; radials pentagonal; interradials smaller as they become more distal; two to three primibrachials, one always included within cup, second primibrachial may be in cup; arms taper distally, uniserial proximally, biserial after first bifurcation, branching varies between species; tegmen small with small marginal anal protuberance; column stout, circular, pentagonal lumen. 
Discussion.--Cribanocrinus has 16 species listed by Webster (2003). It occurred in the late Kinderhookian to Meramecian in the United States; Tournaisian in Australia and China. Kammer and Ausich (2007) add that it occurs in the Tournaisian and Visean in Western Europe and Scotland.

Cribanocrinus coxanus Worthen, 1882

Figure 21.3

Rhodocrinus coxanus Worthen, 1882, p. 20; 1883, p. 305, P1. 28, fig. 7. Miller, S. A., 1889, p. 277. Keyes, 1894a, p. 163, P1. 22, fig. 3. Wachsmuth and Springer, 1897, p. 222, P1. 13, figs. 6-7. Weller, S., 1898c, p. 527.

Rhodocrinites coxanus (Worthen, 1882). Bassler and Moodey, 1943, p. 663. Cribanocrinus coxanus (Worthen, 1882). Kirk, 1944a, p. 15. Webster, 1973, p. 87. Rhodocrinus polydactylus Worthen, 1882, p. 30. Weller, S., 1898c, p. 527. Bassler and Moodey, 1943, p. 663.

Diagnosis.--Calyx bowl shaped with slightly flattened base and recessed column insertion, plates nodose; two primibrachials, with first within calyx, second (axillary) projecting above the calyx; arms have five secundibrachials, all uniserial, variable branching distal to second bifurcation, all arms biserial above secundibrachials.

Material examined.--The following was examined: one specimen from INSM, 71.1.9445.

Discussion.--Cribanocrinus coxanus is listed as occurring in the Osagean Keokuk Limestone. This specimen was found in the Harris Stone Quarry, Bainbridge, Indiana, a definite St. Louis Limestone site. This will place this specimen as the youngest identified Cribanocrinus known thus far from North America (Ausich, personal communication). 
Occurrence.--Keokuk Limestone, Iowa; Eswardsville Formation and St. Louis Limestone, Indiana.

\author{
Suborder Monobathrida Moore and Laudon, 1943 \\ Superfamily CARPocrinacea de Koninck and Le Hon, 1854 \\ Family Batocrinidae Wachsmuth and Springer, 1881 \\ Genus Azygocrinus Lane, 1963
}

Type species.--Actinocrinus dodecadactylus Meek and Worthen, 1861, p.131.

Diagnosis.--Cup bowl shaped; plates flat; three equal basals; five radials, four hexagonal and one pentagonal at base of anals; primanal in line with radials with three anal plates in next higher range, three to eleven anal plates may be between fixed brachials; fixed brachials with one to five interbrachials; 12 to 23 arms, arms "simple" (Ubaghs, 1978), tegmen low, smooth; anal tube short (contrary to Batocrinidae generally which is long) with opening at end; column not known

Discussion.--Azygocrinus has six species listed in Webster (2003). It occurred from the middle Osagean to the Meramecian in the United States. According to Ausich ans Kammer (2010) it occurs in Burlington Limestone in Illinois, Iowa and Missouri.

AzYgocrinus Euconus (Meek and Worthen, 1865) Actinocrinus (Alloprosallocrinus) euconus Meek and Worthen, 1865c, p. 164. Weller, S., 1898c, p. 232. Lane, N. G., 963a, p. 695. Webster, 1973, p. 64; 1977, p. 46. Alloprosallocrinus euconus (Meek and Worthen, 1865). Miller, S. A., 1889, p. 222. 
Batocrinus euconus (Meek and Worthen, 1865). Miller, S. A., 1889, p. 227. Weller, S., 1898c, p. 232. Lane, N. G., 1963a, p. 695. Webster, 1973, p. 64.

Dizygocrinus euconus (Meek and Worthen, 1865). Wachsmuth and Springer, 1897, p. 407, P1. 35, figs. 7a-7b. Weller, S., 1898c, p. 232. Beede, 1906, p. 1252, Pls. 12, fig. 3; 16, figs. 2-2a. Grabau and Shimer, 1910, p. 543, Fig. 1872. Bassler and Moodey, 1943, p. 429. Wolf, 1979, p. 151, FIg. 2, no.h.

Azygocrinus euconus (Meek and Worthen, 1865). Laudon, 1973b, p. 27, Fig. 3. Webster, 1977 , p. 46.

Diagnosis.--Plates smooth; 16 arms; anal tube tall.

Material examined.--None identified from collections studied.

Discussion.--Inconsistency occurs in the anal tube length. Ubaghs (1978) described the family Batocrinidae as having a long slender anal tube and the genus Azygocrinus as having a short anal tube. The figure in Ubaghs shows lacks an anal tube but the figure in Grabau and Shimer (1910) from Worthen shows a long, slender tube. Meek and Worthen announced a new species as genus Actinocrinus, subgenus Alloprosallocrinus, species euconus in 1865 . Their original description of its locality and position was "six miles southeast of Anna, Union Co., Illinois; from the St. Louis division of the Subcarboniferous series. Collected by Mr. Henry Engelmann.” That same designation had been repeated throughout the history of this species without further explanation. In 1897, Wachsmuth and Springer changed the genus to Dizygocrinus. That same designation was used by Grabau and Shimer in 1910, who listed it as only occurring in the Keokuk and Warsaw in Indiana and Illinois. Bassler and Moodey (1943) placed Dizygocrinus euconus within the Salem and the 
Ste.Genevieve limestones while leaving it out of the St. Louis. Lane (1963) remarked that This species was “completely misinterpreted" by Wachsmuth and Springer and designated This species to be Batocrinus euconus. Lane (1963) stated that the only specimen known (University of Illinois no. E1381C) was "reported from the ? St. Louis Group, six miles south of Anna, Illinois. Probably from the Salem.” Webster (2003) placed it within the Salem or the St. Louis. Ausich and Kammer (2010) stated that Batocrinus could not be confirmed to occur anywhere except in the Salem Limestone. As was previously noted, some crinoids were designated as St. Louis referring to the "St. Louis group." Shortening of the term to St. Louis resulted in a historically inaccurate placement of crinoids, which were within the Warsaw, Salem or Ste. Genevieve. Azygocrinus euconus serves as an example. Given the inconsistencies of designations, and the most recent rejection of the placement of this species within the St. Louis by Ausich and Kammer (2010), it will not be included within the St. Louis Limestone.

Occurrence.--Keokuk, Warsaw, and Salem limestones in Iowa, Illinois, Indiana, Kentucky and Missouri.

Superfamily HeXacrinITACEA Wachsmuth and Springer, 1885

Family Dichocrinidae S. A. Miller, 1889

Genus Dichocrinus Munster, 1839

Type species.--Dichocrinus radiatus, Munster, 1839, p. 31

Diagnosis.-- Crown cylindrical; cup bowl to cylindrical; two basals, equal size; radials tall, height to width ratio of $1.5: 1$; plates smooth facets peneplenary; primanal in line with radials; 
two primibrachials; two secundibrachials; arms isotomous branching, subcuneate brachials, 20 arms; pinnules long and closely spaced; anal tube to second bifurcation of arms; column not known but not coiled like Camptocrinus.

Discussion.--Dichocrinus has 46 species listed in Webster (2003). It occurred from the Tournaisian to the Visean in Europe and Russia, the Westphalian in Morocco, the Artinskian to the Wordian in Australia, and the Kinderhookian to the Missourian in North America.

Dichocrinus PaRVuLus (Meek and Worthen, 1865)

Platycrinus parvulus Meek and Worthen, 1865c, p.163. Shumard, 1868, p. 389. Miller, S. A.,1889, p. 271. Weller, S., 1898c, p. 442. Broadhead, 1981, p. 122. Platycrinites parvulus (Meek and Worthen, 1865). Meek and Worthen, 1873, p.555, P1.20, fig. 7. Broadhead, 1981, p. 122.

Dichocrinus huntsvillae Wachsmuth and Springer, 1897, p. 773, Pl. 75, fig. 4.Miller, S. A., 1897, p. 741. Weller, S., 1898c, p. 222. Laudon, 1973b, p. 32, Fig. 7. Broadhead, 1981, p. 122.

Dichocrinus parvulus (Meek and Worthen,1865). Bassler and Moodey, 1943, p. 421. Broadhead, 1981, p. 122, Pl. 8, figs. 6-8, 12-13, 21. Burdick and Strimple, 1983a, p. 175, Pl. 3, fig. 1. Webster, 1988, p. 74.

Diagnosis.--Cup conical to cylindrical, higher than wide; smooth plates; two basals; radials higher than wide, angustary facets, single primibrachial, two secundibrachials; ten 
arms with no further branching, uniserial, cuneate; pinnules alternating, stout.

Material examined.--None

Discussion.--Dichocrinus parvulus is listed as occurring in the St. Louis Limestone by Webster (2003). Bassler and Moodey (1943), Broadhead (1981), and Burdick and Strimple (1982) do not include it in the St. Louis, but in the Chesterian. The source of confusion appears to be the locality by Wachsmuth and Springer (1897) as "St. Louis group; Huntsville and Whitesburg, Alabama.” Again, this demonstrates the recurring mislabeling of that area as St. Louis Limestone.

Occurrence.--St. Louis and Ste. Genevieve limestones, Alabama, Illinois, Iowa and Georgia.

Genus CAmptocrinus Wachsmuth and Springer, 1897

Type species.--Camptocrinus myelodactylus, Wachsmuth and Springer, 1897, p. 779.

Diagnosis.--Crown tall, cylindrical; cup small, conical-cylindrical; two basals, equal with A-CD interbasal suture; five radials, each tall with height-to-width ratio of $3: 1$, angustary facet; primanal between C and D radials, two primibrachials; arms, isotomous branching, uniserial to biserial, two per ray, pendant; column round proximally, lozenge-shaped distally, coiled, covered with long round cirri projecting toward the inside of the coil.

Discussion.--Camptocrinus has 11 species listed in Webster (2003). Occurrences include the late Osagean to the middle Chesterian of the United States, the Visean of Scotland and the Permian of Russia, Australia and Timor. 
CAMptocrinus cirRIFER Wachsmuth and Springer, 1897

Dichocrinus (Camptocrinus) cirrifer Wachsmuth and Springer, (part) 1897, p. 780, P1. 76, figs. 13a-13c. Bassler and Moodey, 1943, p. 354.

Dichocrinus cirrifer Wachsmuth and Springer, 1897. Miller, S. A., 1897, p. 741.

Camptocrinus cirrifer (Wachsmuth and Springer, 1897). Miller, S. A., 1897, p. 740. Weller, S., 1898c, p. 161. Ehrenberg, 1922a, p. 283, Fig. 15; 1926, p. 257, Fig. 5. Springer, 1926b, p. 32, P1. 8, figs.10-10a. Ehrenberg, 1930a, p. 323, Pl. 17, fig. 8. Bassler and Moodey, 1943, p. 354. Laudon, 1973b, p. 32, Fig. 7. Webster, 1977, p. 52. Broadhead, 1985, p. 211, Fig. 5, no. G. Webster, 1988, p. 49. Chestnut and Ettensohn, 1988, p. 57, P1. 8, figs. 16-19. Webster, 1993, p. 35.

Camptocrinus multicirrus Springer, 1926b, p. 31, P1. 8, figs. 4-9. Ehrenberg, 1930a, p. 323, P1. 17, figs. 2, 6-7. Bassler and Moodey, 1943, p. 354. Moore and Laudon, 1944, p. 199, P1. 78, fig. 13. Webster, 1973, p. 77. Ubaghs in Moore and Teichert, 1978, p. T78, Fig. 57, no. 10. Webster, 1986, p. 88. Burdick and Strimple, 1983a, p. 172, Pl. 3, figs. 2, 7-9, 14, 27, 29. Meyer and Ausich, 1983, p. 382, Fig. 1, no. k. Chestnut and Ettensohn, 1988, p. 57.Webster, 1988, p. 49; 1993, p. 35.

Camptocrinus beaveri Moore and Jeffords, 1968. Chestnut and Ettensohn, 1988, p. 57. Webster, 1993, p. 35.

Diagnosis.--The distinguishing characteristic of this species is the arrangement of the cirri on the column. Camptocrinus cirrifer has long, slender cirri. They project from what 
appears to be the junction of two nodals that are fused. A single node, of the same thickness as the combined thickness of the fused nodes, intercedes. Two or three cirri per cirri-bearing nodes project toward the inside of the coil. Two figures from Springer (1926, Plate 8, figures 4a and10a) show two different configurations at the base of the cirri: one shows a uniform presence of three cirri per cirri-bearing node that are separated at the origin; the other shows a common origin with two or three cirri per cirri-bearing node.

Material examined.--Only one specimen was examined, USNM S-2639. This specimen is inadequate as it does not exhibit details of the calyx and had no column to evaluate.

Discussion.--Camptocrinus cirrifer has a history of being synonymized with Camptocrinus multicirrus, which appears to exhibit the same characteristics of the column as one of the variations for C.cirrifer noted above. Because the differentiating characteristic of C. cirrifer is that alone, further specimens would be helpful in making the description more accurate. Occurrence.--St. Louis Limestone, Illinois.

Camptocrinus myelodactylus Wachsmuth and Springer, 1897

Dichocrinus (Camptocrinus) myelodactylus Wachsmuth and Springer, 1897 (part), p. 779, P1. 75, figs. 2-3 only. Bassler and Moodey, 1943, p. 354.

Dichocrinus myelodactylus Wachsmuth and Springer, 1897. Miller, S. A., 1897, p. 742. Camptocrinus myelodactylus (Wachsmuth and Springer, 1897). Miller, S. A., 1897, p. 740. Weller, S., 1898c, p. 162. Springer, 1926b, p. 28, Pl. 7, figs. 2-5b. Ehrenberg, 1930a, p. 323, P1. 17, figs. 4, 9. Bassler, 1938, p. 59. Bassler and Moodey, 1943, p. 355. Ubaghs, 
1953, p. 741, Figs. 129-130. Webster, 1973, p. 77. Laudon, 1973b, p. 32, Fig. 7.

Webster, 1977, p. 52. Lane in Moore and Teichert, 1978, p. T477, Fig. 281, no. 2.

Webster, 1986, p. 88.

Diagnosis.--The distribution of cirri on the column provides the differentiating characteristic for Camptocrinus myelodactylus. The cirri are strong, rounded, long and tapered. Fifteen to twenty diminishing cirri are distributed along the column and can be doubled or tripled from each side of the cirri-bearing nodes. The nodes are the same as Camptocrinus cirrifer with a pair apparently fused to the same width as the intervening noncirri-bearing nodes.

Material examined.--None (noting that the one specimen included for $C$. cirrifer could easily be this species)

Occurrence.--Indian Creek, Edwardsville Formation (Kammer et al., 1998) and St. Louis Limestone in Indiana.

Genus Hyrtanecrinus Broadhead and Strimple, 1980

Type species.--Hyrtanecrinus diabolus Broadhead, 1981, p. 130.

Diagnosis.--Crown tall, cylindrical; cup small, conical-cylindrical; two basals, equal with A-CD interbasal suture; five radials, each tall with height-to-width ratio of 3:1, angustary facet; tegmen expands laterally beyond cup margins in most species; short tube between C and $\mathrm{D}$ rays made up of three or four anal plates resting directly upon primanal; primanal is between the $\mathrm{C}$ and $\mathrm{D}$ radials; two primibrachials; arms, isotomous branching, uniserial to 
biserial, two per ray, pendant; column round proximally, lozenge-shaped distally, coiled, covered with long round cirri projecting toward the inside of the coil.

Discussion.--Hyrtanecrinus has four species listed in Webster (2003). It occurs from the Osagean to the Chesterian in the United States.

Hyrtanecrinus ornatus Wachsmuth and Springer, 1881

Dichocrinus sculptus Casseday and Lyon, 1862 (non D. sculptus de Koninck and Le Hon, 1854), p. 25. Bassler and Moodey, 1943, p. 421. Broadhead, 1981, p. 130. Webster, 1988, p. 97.

Dichocrinus ornatus (Wachsmuth and Springer, 1881) (non D. sculptus de Koninck and Le Hon, 1854), p. 762, Pl. 77, fig. 6. Miller, S. A., 1889, p. 239. Weller, S., 1898c, p. 223. Bassler and Moodey, 1943, p. 421. Laudon, 1973b, p. 32, Figs. 1, 7. Webster, 1977, p. 70. Broadhead, 1981, p.130. Webster, 1988, p. 97.

Hyrtanecrinus ornatus (Wachsmuth and Springer, 1881). Broadhead, 1981, p. 130, Pl. 12, figs. 1-4, 6-8, 10, 13-14, 22. Webster, 1988, p. 97.

Dichocrinus blatchleyi Beede, 1906, p. 1259, Pl. 17, figs. 2-2f. Bassler and Moodey, 1943, p. 418. Broadhead, 1981, p. 130. Webster, 1988, p. 97.

Diagnosis.--Cup equidimensional to slightly elongate, sub-conical; plates, pronounced longitudinal, oblique and transverse striae; tegmen nodose, narrower to slightly broader than cup; 20 arms; long closely spaced pinnules; anal cone base of tegmen above perianal, column not known.

Material examined.--None. 
Discussion.--According to Broadhead (1981), the unusual obvious cup plate stria of Hyrtanecrinus ornatus occurred for a short interval after its evolution from Dichocrinus dichotomus Hall (1860). Descendants from Hyrtanecrinus ornatus had a single primibrachial that is diagnostic of Talarocrinus. Talarocrinus was one of the genera that persisted into the Chesterian along with Dichocrinus. All three genera have been found in the Salem, St. Louis and Ste. Genevieve limestones with only Hyrtanecrinus ornatus, the apparent intermediary, having the heavy stria markings. It is noted that Webster (2003) listed the ranges of the four species of Hyrtanecrinus as either from the Osagean to the Meramecian or from the Meramecian to the Chesterian. Hyrtanecrinus ornatus is the only one found in the St. Louis Limestone.

Occurrence.--Osagean, Keokuk Limestone in Iowa, Fort Payne Chert in Kentucky; Meramecian, Salem and St. Louis limestones in Indiana; Chesterian, Shetlerville and Paint Creek Formations.

Genus TaLARocrinus Wachsmuth and Springer, 1881

Type species.--Dichocrinus cornigerus Shumard, 1857, p.72.

Diagnosis.--Crown slightly flaring cylinder; small calyx plates slightly larger than Dichocrinus; two equal basals; five radials, tall with height-to-width ratio of 3:2; primanal in line with radials; tegmen same height as cup, oral and anal opening to side high on the tegmen; one primibrachial, small; one secundibrachial, contacts lateral edge of radial facet; four arms in each ray, biserial. 
Discussion.--Talarocrinus has 18 species listed in Webster (2003). It occurs from the Meramecian to the middle Chesterian in the United States. Kammer and Springer (2008, fig.6) summarized the ranges of Talarocrinus species. Although the species of Talarocrinus changed through the Meramecian, this genus persisted in various forms throughout. Along with Platycrinites and Dichocrinus, Talarocrinus is one of the few camerates to thrive into the Chesterian.

TALAROCRINUS CORNIGERUS Shumard, 1857.

Dichocrinus cornigerus Shumard, 1857, p. 72, Pl. 1, figs. 1a-1d; 1868, p. 393. Meek and Worthen, 1873, p. 537, Pl. 20, fig. 6. Miller, S. A., 1889, p. 239. Weller, S., 1898c, p. 623. Bassler, 1938, p. 180. Bassler and Moodey, 1943, p. 699.

Talarocrinus cornigerus (Shumard, 1857). Wachsmuth and Springer, 1881, p. 87. Miller, S. A., 1889, p. 285. Wachsmuth and Springer, 1897, p. 783, Pl. 78, figs. 6-7. Weller, S., 1898c, p. 623. Grabau and Shimer, 1910, p. 522, Fig. 1847. Ulrich, E. O., 1917, p. 266, Pl. 8, figs. 18-19; Pl. 9, figs. 7-8. Weller, S., 1920, p. 340, Pl. 6, fig. 35. Springer, 1926b, p. 46, Pl. 14, fig. 6. Butts, C., 1941, p. 250, Pl. 132, figs. 30-34. Bassler and Moodey, 1943, p. 699. Moore and Laudon, 1944, p. 199, Pl. 78, fig. 12. Lane in Moore and Teichert, 1978, p. T479, Fig. 281, nos. 4b-4d. Broadhead, 1985, p. 211, Fig. 6, nos. C-D. Webster, 1986, p. 299; 1988, p. 156.

Diagnosis.--Crown ellipsoid; cup bowl shaped, flat base; basals 1/4 height of cup, smooth; radials tall, height-to-width ratio of 5:2; tegmen tall, equal height to cup, with large number of tubercles, about five per vertical row (this is its most distinguishing characteristic), conical 
upper tegmen; anal tube $2 / 3$ height of tegmen with opening posterior and distal, multiple polygonal plates; arms and column not available.

Material examined.--None.

Discussion.--Talarocrinus cornigerus demonstrates a trend for the species of Talarocrinus within the St. Louis Limestone to have a larger number and size of tubercles on its tegmen. This may exhibit an increased need for protection against predators.

Occurrence.--St. Louis Limestone, Paint Creek Formation, Ohara Formation, Gasper Limestone in Illinois, Alabama and Virginia.

TALARocrinus SEXLOBATUS Shumard, 1867

Dichocrinus sex-lobatus Shumard, 1867, p. 73, Pl. 1, figs. 3a-3e; 1868, p. 394. Weller, S., 1898c, p. 624. Bassler and Moodey, 1943, p. 700.

Pterotocrinus sex-lobatus (Shumard, 1857). Shumard, 1868, p. 394.

Dichocrinus sexlobatus (Shumard, 1857). Miller, S. A., 1889, p. 239.

Pterotocrinus sexlobatus (Shumard, 1857). Miller, S. A., 1889, p. 276.

Talarocrinus sexlobatus (Shumard, 1867). Wachsmuth and Springer, 1881, p. 87. Miller, S. A., 1889, p. 285 . Wachsmuth and Springer, 1897, p. 784, P1. 78, figs. 1a-1c. Weller, S., 1898c, p. 624. Ulrich, E. O., 1917, p. 267, Pls. 8, figs. 24-25; 9, figs. 12-16. Springer, 1926a, p. 46, Pl. 13, fig. 15. Bassler and Moodey, 1943, p. 700. Laudon, 1973b, p. 32, Fig. 7. Webster, 1977, p. 166.

Diagnosis.--Crown cylindrical; cup ovoid base, bowl shaped, equal height to tegmen; plates smooth; basals 1/5 height of cup; radials height-to-width ratio, 5:4; two large anal plates supporting a small anal tube that approximates the size of one anal plate with opening 
distal and to the side; five large spikes project around upper tegmen with a small dome cap; no arms or column available.

Material examined.--None.

Discussion.--Talarocrinus sexlobatus demonstrates the large tubercles seen in

Talarocrinus in the St. Louis Limestone. Although listed by Webster as being in the St. Louis Limestone, Talarocrinus sexlobatus was placed in the upper part of the St. Louis group by Wachsmuth and Springer (1897) which, by the nomenclature of the time, would have been the Ste.Genevieve Limestone. Bassler and Moodey (1943) placed it only in the Chesterian, Gasper Oolite. This species appears to have been misplaced due to the common confusion of the use of St. Louis Limestone for St. Louis Group, therefore, it will no longer be included with the St. Louis Limestone.

Occurrence.-- Gasper Oolite in Kentucky and Virginia.

TALAROCRINUS SIMPLEX Shumard 1857, p.74.

Dichocrinus simplex Shumard, 1857, p. 74, P1. 1, figs. 2a-2b. Hall, 1858c, p. 654, P1. 22, figs. 12a-12b; 1859a, Pl. 1, figs. 4a-4c. Shumard, 1868, p. 366. Miller, S. A., 1889, p. 239. Weller, S., 1898c, p. 624. Bassler and Moodey, 1943, p. 700. Broadhead, 1981, p. 125, P1. 8, figs. 1, 4-5, 9-10, 15. Feldman, 1989b, p. 907, Fig. 4, no. 1. Webster, 1988, p. 75.

Talarocrinus simplex (Shumard, 1857). Keyes, 1894a, p. 205, P1. 25, fig. 6. Wachsmuth and Springer, 1897, p. 790, P1. 78, figs. 8a-8b. Weller, S., 1898c, p. 624. Rowley, 1902a, p. 91, Pl. 29, figs. 24-27; 1906, p. 30, Pl. 6, figs. 10-11, 19. Beede, 1906, p. 1261, P1. 13, figs. 7-7c. Wood, E., 1909, p. 42, Pl. 13, fig. 1. Grabau and Shimer, 1910, p. 522. 
Weller, J. M., 1917, p. 256, P1. 35, figs. 9a-9b. Bassler and Moodey, 1943, p.700.

Laudon, 1973b, p. 32, Fig. 7. Conkin and Conkin, 1976, p. 226, Pl. 11. Webster, 1977, p. 166; 1988, p. 157.

Doliolocrinites ovalis (Troost ms) Hall, 1858c, p. 655. Bassler, 1938, p. 89. Bassler and Moodey, 1943, p. 700.

Diagnosis.--Cup cylindrical, rounded base, smooth plates; large basals compared to other Talarocrinus species, height equal to width; radials just slightly taller than basals, almost rectangular, angustary facet; no tegmen, anal tube, arms or column available.

Material examined.--None.

Discussion.--None

Occurrence.--Warsaw Limestone, Somerset Shale Member of Salem Limestone, St. Louis Limestone in Kentucky, Indiana, Missouri and Tennessee.

Family ACrocrinidae Wachsmuth and Springer, 1885

Genus Amphoracrocrinus Moore and Strimple, 1969

Type species.--Acrocrinus amphora Moore and Strimple, 1969, p. 9.

Diagnosis.--Crown urn shaped, tall; cup medium, tall, urn; infrabasals, none; two basals evenly divided; numerous intercalaries, 12 distally, five subradial, seven interradial including sub-anal; five hexagonal radials, peneplanary facets; radianal (only anal) hexagonal, in line with radials and same size as radials; small primibrachial; few (two or three) secundibrachials; number of arms not known, strong, biserial and erect, large number of 
pinnules; tegmen has a large number of small plates with no identifiable oral plates, no anal pyramid; column round.

Discussion.--Amphoracrocrinus has only a single species listed by Webster (2003). It occurred in the Monteagle Limestone and Gasper Formation in Alabama.

AMPHORACrocrinus AMPHORA Wachsmuth and Springer, 1897

Acrocrinus amphora Wachsmuth and Springer, 1897, p. 808, P1. 80, figs. 4-9. Weller, S., 1898c, p. 54. Bather in Lankester, 1900, p. 159, Fig. 73. Abel, 1924, p. 276, Fig. 410. Springer, 1926b, p. 45, Pls. 9, figs. 8-9; 12, figs. 8-9; 18, fig. 4. Bassler and Moodey, 1943, p. 265. Moore and Laudon, 1943b, p. 142, P1. 13,fig. 3; 1944, p.199, P1.78, fig. 15. Cuénot, 1948, p. 69. Fig. 91. Ubaghs, 1953, p.741, Fig. 2. Moore and Strimple 1969a, p.9. Webster, 1973, p. 4; 1977, p.38

Amphoracrocrinus amphora (Wachsmuth and Springer, 1897). Moore and Strimple, 1969a, p. 9, Figs. 1, no. 3; 2, nos. 4-8. Webster, 1977, p. 38. Ubaghs in Moore and Teichert, 1978, p. T129, T143, Figs. 101, no. 1; 113, no. 8. Moore and Strimple in Moore and Teichert, 1978, p. T480, Figs. 282, no. 2; 283, no. 2. Burdick and Strimple, 1983a, p. 194, Pl. 14, fig. 10. Broadhead, 1985, p. 211, Fig. 4, no. A. Webster, 1986, p. 56; 1988, p. 35.

Diagnosis.--Being the only species in this genus, Amphoracocrinus amphora does not have differentiating characters beyond that described for the genus.

Material examined.--None

Discussion.--No reference was found stating that this species was found anywhere other than in Alabama. A questionable specimen in the USNM-S collection is labeled "St. Louis, 
St. Louis, Mo." The accuracy of this being a species from the St. Louis Limestone must be considered. Amphoracrocrinus amphora is listed in Moore and Laudon (1943) as being in the St. Louis Limestone; Moore and Laudon (1944) later listed it as "Mississippian, Alabama." Bassler and Mooney (1943) listed it as "Mississippian, Chesterian-Gasperian.” Burdick and Strimple (1983) stated that it is not St. Louis but is Genevievian. This appears to be the result of miscorrelation of the Monteagle Limestone of Alabama with the St. Louis Limestone.

Occurrence.--Monteagle Limestone, Gasper Formation, Alabama.

Superfamily Platycrinitacea Austin and Austin, 1842

Family Platycrinitidae Austin and Austin, 1842

Genus Platycrinites s.1. Miller, 1821

Type species.--Platycrinites laevis Miller, 1821, p.73.

Diagnosis.--Calyx bowl shaped; cup depressed base; three basals, two larger, one smaller, $1 / 3$ cup height; five radials, hexagonal, $2 / 3$ cup height, angustary upper facets; tegmen flat to pyramidal; anal opening eccentric with no anal tube or up to various lengths, short to long; primibrachials single with heterotomous branching, branching above contains few brachials per division (one or two) before branching from one to five higher divisions, above the last division, the arms are long, the joints range from subcuneate proximally to cuneate to biserial distally; dense slender pinnules; columnals round proximally, elliptical and twisted distally.

Discussion.--Platycrinites has a complex history of name changes. Platycrinites was the original name ascribed by J. S. Miller in 1821. The name was changed to Platycrinus by Phillips (1836), only to be changed back to Platycrinites by later workers. Approximately 
208 species are listed for the genus Platycrinites in Webster's (2003) as well as several pages of synonyms from Platycrinus. They appear not only to have occurred in great numbers but are world-wide and occupy a time span between the Tournaisian and the late Carboniferous (Ausich and Kammer, 2009). Most of the differentiating morphology between the species of Platycrinites relate to the different sculpturing of the basal and radial plates, calyx shape and relative size of circlets. Although this issue has been alleviated by Ausich and Kammer (1990) by synonymizing several species, the accurate identification between species continues to be difficult. Ausich and Kammer (2009) further clarified the identification by objectively defining genera within the Platycrinitidae. Many of the previously assigned genera within this family were defined and renamed. They also differentiated the use of genus-diagnostic characters used in Europe from those of North America. This effort resulted in Platycrinites s.s. including 14 species and Platycrinites s.l. having 76 species.

Platycrinites appears to be the most diverse taxon identified within the St.Louis Limestone.

Platycrinites s.l. sarae. Hall, 1858

Figure 19.3, 19.4

Platycrinus sarae Hall, 1858c, p. 673, Pl. 17, fig. 4. Shumard, 1868, p. 390. Miller, S. A., 1889, p. 271. Weller, S., 1898c, p. 445. Grabau and Shimer, 1910, p. 520. Schmidt, H., 1929, p. 83, Pl. 20, figs. 11.

Platycrinites sarae (Hall, 1858). Bassler and Moodey, 1943, p. 626. Laudon, 1973b, p. 31,

Fig. 6. Webster, 1977, p. 139. Ausich and Kammer, 1990, p.767, Figs. 6.1, 6.3. Webster, 1993, p. 95. 
Platycrinites s.l. sarae (Hall, 1858). Ausich and Kammer, 2009, p. 695.

Diagnosis.--Large size, compared to other Platycrinites, ridges parallel to plate boundaries on radials and basals; radial plate height-to-width ratio 1:1; six arms per ray; radial facet width $1 / 3$ total width; column alternating thick and thinner internodals, round to elliptical but twisted minimally in specimens observed. 

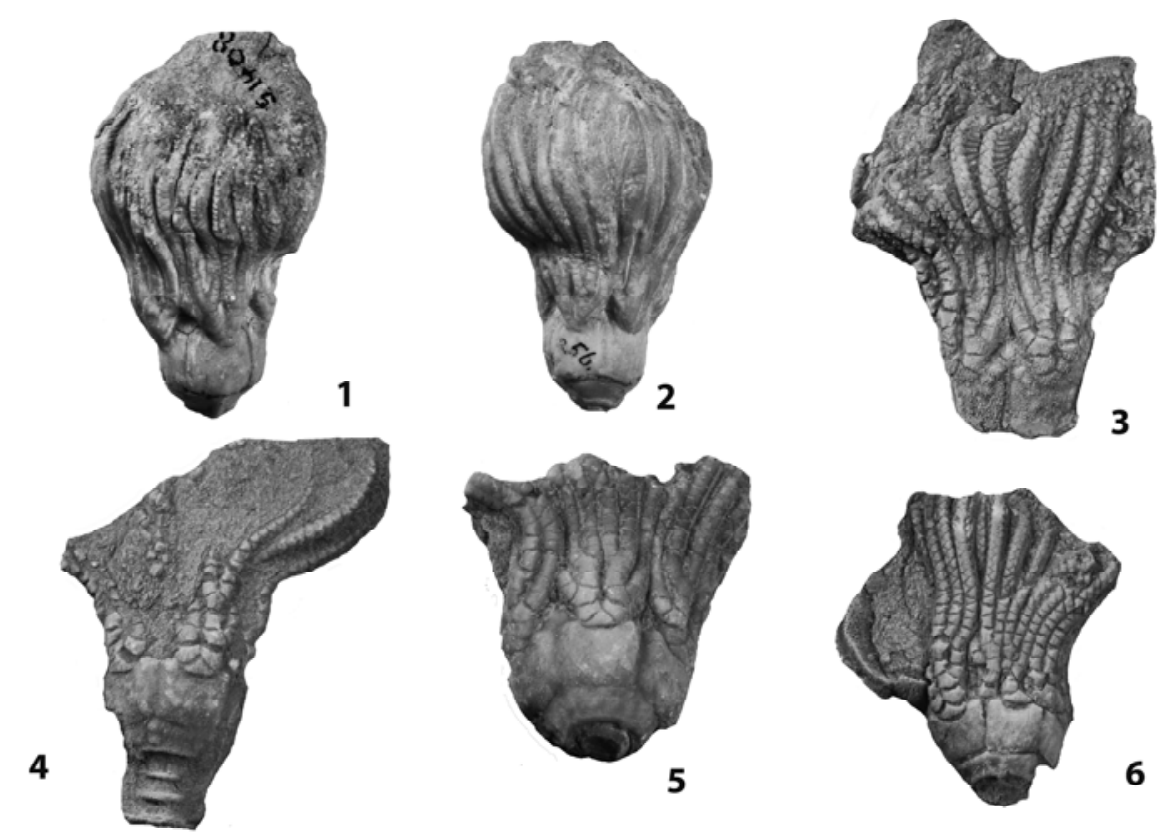

Figure 19. Camerates of the St. Louis Limestone. 1,2, Platycrinites niotensis (Meek and Worthen, 1865), USNM, S-1408, anterior view X1.0; 3,4, Platycrinites sarae (Hall, 1858), USNM, S-2639, X2.0; 5,6 Platycrinites pumilus (Hall, 1860), USNM, S-2639, X2.0, USNM, S-2639, X1.5.

Material examined.--The following were examined; ten specimens from USNM, S-2639. None were contained in the INSM or FMNH collections.

Discussion.--Within the specimens studied the ridges on the radials were not consistently seen. The lack of columnals of sufficient length and detail does not allow for an adequate description of that morphology. This problem appears to be common among other investigators, who avoid a thorough discussion of the columnal morphology.

Occurrence.--Osagean through Meramecian; Keokuk Limestone, Warsaw Formation, and St. Louis Limestone in Missouri, Illinois and Kentucky. 


\section{Platycrinites s.1. Pumilis Hall, 1860}

Figure 19.5, 19.6

Platycrinus pumilus Hall, 1859a, p. 82, P1. 1, fig. 6. Shumard, 1868, p. 389. Miller, S. A., 1889, p. 271. Weller, S., 1898c, p. 444. Bassler and Moodey, 1943, p.625. Ausich and Kammer, 1990, p. 770.

Platycrinites pumilus (Hall, 1859). Bassler and Moodey, 1943, p. 625. Ausich and Kammer, 1990, p.770, Figs. 6.2, 6.9, 6.12. Webster, 1993, p. 94.

Platycrinus prattenanus Meek and Worthen, 1860, p. 379; 1866a, p. 264, P1. 20, fig. 2. Miller, S. A., 1889, p. 271. Weller, S., 1898c, p. 445. Bassler and Moodey, 1943, p. 626. Ausich and Kammer, 1990, p. 770.

Platycrinus prattenianus Meek and Worthen, 1860. Shumard, 1868, p. 389 (sic).

Platycrinus monroensis Worthen, 1882, p. 30; 1883, p. 306, P1. 30, fig. 9. Miller, S.A., 1889, p. 271.Weller, S. 1898c, p. 445. Bassler and Moodey, 1943, p. 626. Ausich and Kammer, 1990, p. 770.

Platycrinites s.1. pumulus (Hall, 1859). Ausich and Kammer, 2009, p. 695.

Diagnosis.--Small to medium size; radial plates smooth; basals smooth or inter-basal ridges; base truncate, horizontal to basal concavity; basal plates $2 / 3$ height of cup; radial plate wider than high; six arms.

Material examined.--The following were examined: five specimens, USNM S-2639. Discussion.--Platycrinites pumilus is most similar to P. sarae of the species within the specimens studied. Size differences and variation of plate sculpturing are the essential differentiating components. 
Occurrence.--Warsaw Limestone, Salem Limestone and St. Louis Limestone in Missouri and Illinois.

\section{Platycrinites s.l. NIOTENSIs Meek and Worthen, 1865}

Figure 19.1, 19.2

Platycrinus niotensis Meek and Worthen, 1865c, p. 162; 1868c, p. 513, Pl. 20, fig. 3;

Unnum. Fig. Shumard, 1868, p. 388. Miller, S. A., 1889, p. 271, Fig. 396. Weller, S., 1898c, p. 442. Bassler and Moodey, 1943, p. 623. Ausich and Kammer, 1990, p. 771. non Platycrinus niotensis Meek and Worthen, 1865. Wachsmuth and Springer, 1897, Pl. 17, fig. 9. Bassler and Moodey, 1943, p. 623. Ausich and Kammer, 1990, p. 771. Platycrinus pentagonus Miller, S. A., 1891b, p. 16, P1. 2, fig. 1; 1892a, p. 681. Weller, S., 1898c, p. 443. Bassler and Moodey, 1943, p. 624. Ausich and Kammer, 1990, p. 771. Platycrinites pentagonus (Miller, 1891). Bassler and Moodey, 1943, p. 624. Ausich and Kammer, 1990, p. 771.

Platycrinus (Cupellecrinus) pentagonalis Bigsby, 1868, p. 22. (probably a misspelling of $P$. pentagonus, GDW)

Platycrinites niotensis (Meek and Worthen,1865). Bassler and Moodey, 1943, p.623. Ausich and Kammer, 1990, p. 771, Figs. 6.7-6.8, 6.10-6.11. Webster, 1993, p. 94.

Platycrinites s.1. niotensis (Meek and Worthen, 1865). Ausich and Kammer, 2009, p. 695.

Diagnosis.--Small to medium size; radial plates smooth; basals smooth or interbasal ridges; base truncate or rounded; radials height equals width; four to six arms.

Material examined.--The following were examined: two specimens from INSM, 71.1.9444, 9529; twenty-four from USNM S-2639 
Discussion.--Platycrinites niotensis is similar in morphology to both P. sarae and P. pumilus. The character that shows the greatest difference is the number of arms. P. niotensis has four to six, which overlap the other two species. On reviewing the extensive analysis of similarities and differences among the species of Platycrinities by Ausich and Kammer (1990), it is noted that these three species fall together in many of the characters evaluated. This may indicate a common adaptive process to a common environment.

Occurrence.--Keokuk Limestone and Warsaw Limestone in Illinois, Iowa and Missouri. This species is listed by Webster (2003) and Ausich and Kammer (1990) as having a questionable occurrence in the St. Louis Limestone. The fact that two specimens of Platycrinites niotensis were found at the Harris Stone Quarry, Bainbridge, Indiana--a known St. Louis Limestone site--negates that question.

Platycrinites faberi Miller, 1889

Platycrinus faberi Miller, S. A., 1889, p. 270, Fig. 393. Weller, S., 1898c, p. 439. Bassler and Moodey, 1943, p. 620.

Platycrinites faberi (Miller, 1889). Bassler and Moodey, 1943, p. 620.

Diagnosis.--Basals marked by three "keels" (Miller, 1889), which may correspond to the sutures between the plates; radials wider than high, facet for primibrachial occupies $1 / 3$ width of the plate, tubercles on the surface of radials radiate from the center to the lower corners of the plate, scattered tubercles are present on the radials in addition to those in line.

Materials examined.--None 
Discussion.--This species was named by S. A. Miller (1889) based on a specimen that included only the cup. His distinguishing morphology was the "keels" at the suture lines of the basals. That same morphology is present on Platycrinites pumilus. There is also confusion about the location. Miller stated that the specimen was "collected in Scott County, West Va., in the St. Louis or Kaskaskia Gr.” Although the St. Louis Limestone is correlated with the Hillsdale Limestone of the Greenbrier Limestone Group in Virginia and West Virginia, the St. Louis Limestone per se does not exist in these two states. Because no Scott County exists in West Virginia but there is a Scott County in western Virginia, the locality is probably in Virginia, which is what Kammer and Springer (2008) concluded. It is also noted that no other examples of this species are known from either state. P. faberi is probably a synonym for $P$. pumilus. Without the type specimen, synonymization will not be attempted in this work.

Occurrence.--?Greenbrier Limestone, Scott County, Virginia.

\section{Platycrinites huntsvillae Troost, 1850}

Platycrinites huntsvillae Troost, 1850a, p. 61; 1850b, p. 420. Bassler and Moodey, 1943, p. 622. Ubaghs, 1953, p. 743, Fig. 55. Laudon, 1973b, p. 31, Fig. 6. Webster, 1973, p. 213; 1977, p. 138.

Platycrinus huntsvillae (Troost, 1850). Shumard, 1868, p. 388. Miller, S. A., 1889, p. 271.

Wachsmuth and Springer, 1897, p. 678, Pl. 73, figs. 6-12. Miller, S. A., 1897, p. 750.

Weller, S., 1898c, p. 440. Bather in Lankester, 1900, p. 158, Fig. 71, no. 2. Wood, E., 1909, p. 38, P1. 5, figs. 10-12. Grabau and Shimer, 1910, p.520, Figs. 1806, nos. b-c; 
1843. Butts, C., 1917, p. 59, Pl. 14, figs. 1-8. Miller, A.M., 1919, p. 108, P1. 59, figs. 18. Butts, C., 1926, p. 181, P1. 59, figs. 27-31.

Platycrinites polydactylus Troost,1850a, 62; 1850b, p. 420. Wood, E.,1909, p. 38. Bassler and Moodey, 1943, p. 622.

Platycrinus polydactylus Troost, 1850. Shumard, 1868, p. 389. Miller, S. A., 1889, p. 271. Platycrinus plenus Meek and Worthen, 1860, p. 381; 1866a, p. 267, P1. 20, fig. 3. Shumard, 1868, p. 389. Miller, S. A., 1889, p. 271. Weller, S., 1898c, p. 440. Platycrinus alabamensis Miller, S. A., 1891c, p. 50 (adv. pub.); 1892a, p. 681; 1892b, p. 660, P1. 9, fig. 5. Weller, S., 1898c, p. 440.

Platycrinus penicillus Meek and Worthen, 1860, p. 380; 1866a, p. 266, P1. 19, figs. 6a-6b.

Shumard, 1868, p. 389. Miller, S. A., 1889, p. 271. Weller, S., 1898c, p. 440; 1917, p. 258, P1. 38, figs. 2a-2c; 1920, p. 333, P1. 5, figs. 1-4. Butts, C., 1941, p. 251, P1. 132, figs. 45-53. Bassler and Moodey, 1943, p. 622. Butts, C., 1948, p. 46, Pl. 6, figs. 11-18. Webster, 1973, p. 213.

Platycrinites penicillus (Meek and Worthen, 1860). Burdick and Strimple, 1983a, p.167, P1. 2, figs. 4, 6, 8-9, 11, 13. Horowitz, 1984, p. 8. Webster, 1988, p. 134.

Diagnosis.--Platycrinites huntsvillae is not distinquished, as are most of the other species in this genus, by characteristic sculpturing of the basal or radial plates (Burdick and Strimple, 1982). It is characterized by Meek and Worthen (1860 and Burdick and Strimple (1982) as having spines radiating out from each elliptical columnal. Material examined.--None 
Discussion.--Through much of this species' history it was referred to as Platycrinites penicillus (Synonymized by Webster, 1988), the index fossil for the Ste. Genevieve Limestone. Burdick and Strimple (1982) listed it as Genevievian and as being found in the Monteagle Limestone in Alabama. Meek and Worthen (1866) had stated that it occurred in Hardin County, Illinois, in the St. Louis. Weller (1920) referred to "undisputed" occurrence of Platycrinus penicillus in the St. Louis because it was found below a stratum that contained Lithostrotion canadensis, which is considered to be only in the St. Louis Limestone. In that same paper Weller advocated that the Ste. Genevieve Limestone was actually a part of the St. Louis Limestone. Swann (1963) placed Platycrinites penicillus in the Ste. Genevieve. He stated that the Ste. Genevieve Limestone contained the "last occurrence of Platycrinites penicillus." Swann also stated that the Aux Vases Formation, which is above the Ste. Genevieve, contained Platycrinites penicillus. This appears to be conflicting and reflects the difficulty in delineating the upper boundary of the Ste. Genevieve as well as the lower boundary with the St. Louis. Again, the lack of distinction of the St. Louis-Ste. Genevieve boundary may have confused the issue of locating Platycrinites penicillus within the St. Louis Limestone. Although this controversy must be kept in mind, the more recent trend to associate Platycrinites huntsvillae only with the Ste. Genevieve will be accepted here.

Occurrence.--Ste. Genevieve in Alabama, Illinois, Kentucky, Virginia and Georgia.

Order Cladida Moore and Laudon, 1943

Suborder Cyathocrinina Bather, 1899, 1918

Superfamily Cyathocrinitacea Bassler, 1938

Family Cyathocrinitidae Bassler, 1938 
Genus Cyathocrinites Miller, 1821

Type species.--Cyathocrinites planus Miller, 1821; SD Wachsmuth and Springer 1880.

Diagnosis.--Crown bowl shaped; cup spherical to bowl shaped; infrabasals small to $1 / 3$ the size of the basals; basals hexagonal, height to width ratio of 1:1, smooth; radials pentagonal, angustary facet; single anal plate, anal $X$, in cup between radials and $1 / 2$ the height of the radials; anal sac is $1 / 2$ the length of the arms, composed of polygonal plates; primibrachials vary from one to six, can vary within the same specimen; arm branching can be isotomotous or heterotomous, can have up to seven bifurcations, tapering distally, no pinnules, brachials subcuneate; column round or pentagonal.

Discussion.--Cyathocrinites has 90 species listed in Webster (2003). It occurred worldwide from the Silurian to the Permian.

Cyathocrinites globosus Troost, 1850

Cyathocrinus globosus Troost, 1850a, p. 61; 1850b, p. 419 (nomen nudum). Miller, S. A., 1889, p. 235. Troost, Ms, in Wood, E., 1909, p. 82, Pl. 5, figs. 17-18. Bassler, 1915, p. 317.

Cyathocrinites globosus (Troost, 1850). Bassler, 1915, p. 317. Bassler and Moodey, 1943, p. 391.

Diagnosis.--Troost's description is as follows according to Wood (1909): "It differs from the preceding in being more elevated, the costals [basals] being in proportion much larger. The pelvis [base] does not penetrate into the body but is level with the surface of the cup- 
and the angles of the pelvis [infrabasals plates] being more acute and running partly between the costals [basals] gives it the form of a star, which is perforated by a pentagonal aperture." Materials examined.--None

Discussion.--The type specimen is missing (Wood, 1909). The drawing provided by Wood does not appear to be a Cyathocrinites. Wood also assigned C. globosus to the Silurian Brownsport Limestone instead of the St. Louis Limestone as was listed by Bassler and Moody (1943). Bassler and Moodey (1943) did not recognize it as a legitimate species.

Given the lack of a type specimen, the apparent inaccurate representation of the only figure known, and an unclear description, it will not be included as a St. Louis Limestone crinoid in this work.

Occurrence.--? St. Louis Limestone (may be Brownsport Limestone, Silurian), Tennessee.

Family BARYCRINIDAE Jaekel, 1918

Genus BARYCRINus Meek and Worthen, 1868

Type Species.--Cyathocrinus spurious Hall, 1858, p. 625.

Diagnosis.--Crown robust, tall, subcylindrical, plates thick; cup bowl shaped; infrabasals small but visible from side; basals hexagonal, slightly wider than high, smooth; radials pentagonal, augustary facet, smooth surface; radianal abuts C and D basals and D radial, anal $\mathrm{X}$ in line but slightly elevated between the $\mathrm{C}$ and $\mathrm{D}$ radials, some specimens lack a radianal; two primibrachials typical but up to six can be present; arms branch once isotomously, uniserial, brachials rectangular to subcuneate, ramules branch off arms on alternating sides of every other secundibrachial; anal sac short; column stout, round or pentagonal. 
Discussion.--Barycrinus has 24 species listed in Webster (2003). It occurred in the United States from the Kinderhookian to the Meramecian. In Scotland, it occurred during the Tournaisian and Visean (Kammer and Ausich, 2007).

BaryCRINUS SPECTABILIS Meek and Worthen, 1870, p. 23.

Cyathocrinus (Barycrinus) spectabilis Meek and Worthen, 1870. Meek and Worthen, 1873, p. 530, P1. 20, fig. 8. Bassler and Moodey, 1943, p. 319. Kammer and Ausich, 1996, p. 849

Barycrinus spectabilis Meek and Worthen, 1870b, p. 23. Miller, S. A., 1889, p. 227. Weller, S., 1898c, p. 121. Bassler and Moodey, 1943, p. 319. Kammer and Ausich, 1996, p. 849. Gahn and Kammer, 2002, p.127, fig. 1.15.

Diagnosis.--Robust ridges and nodes on the aboral cup plates; single anal plate, anal X; two primibrachials; two arms, ramules begin on the eighth secundibrachial.

Materials examined.--One possible specimen, ISM 71.1.9429 of this species was found in the collections, but the quality was very poor. A photograph from Gahn and Kammer (2002, p.127, fig 1.15) was reviewed.

Discussion.--Barycrinus spectabilis is the type species for this genus. It was designated as a St.Louis crinoid by Meek and Worthen in 1873. All of the other species of this genus precede B. spectabilis and most occur in the Keokuk and Warsaw limestones. It is a descendant of $B$. rhombiferous (Kammer and Ausich, 1996); thus the changes in morphology may represent an evolutionary step responding to a change in the environment. Robust ridges may have strengthened plates against predators.

Occurrence.--St. Louis Limestone, Otter Creek, Illinois (Gahn and Kammer, 2002). 
.Suborder DENDRocRinda Bather, 1899

Superfamily ScytaLocrinacea Moore and Laudon, 1943

Family ScytaLocrinidae Moore and Laudon, 1943

Genus Phacelocrinus Kirk, 1940

Type species.--Poteriocrinus wetherby S. A. Miller, 1889, p. 275.

Diagnosis.--Crown high, subcylindrical and flaring upward; cup steeply conical; infrabasals high and pentagonal; basals hexagonal, high, flaring upward; radials pentagonal, gaping plenary facets; radianal in contact with $\mathrm{BC}$ and $\mathrm{CD}$ basals; radianal and anal $\mathrm{X}$ between radials, right tube plate contacts $\mathrm{D}$ radial; anal sac cylindrical, maximum height four times height of cup [Moore and Laudon (1944) figure 60-5b shows an anal sac much higher]; anal plates small and in vertical parallel rows; two arms with each ray branching on primibrachial one or two, uniserial, long and slender, first two primibrachials but can be fused with central constriction; cuneate brachial plates and no secondary branching in St. Louis species (branching can occur in some Chesterian species (Kirk, 1940)); pinnules; column pentagonal.

Discussion.--Phacelocrinus has 12 species listed by Webster (2003). It occurred in England and Ireland during the Tournaisian. In the United States it is found from the Meramecian through the Morrowan.

Phacelocrinus dactyliformis Hall, 1858

Figure 20.8, 20.9, 20.10

Poteriocrinus (Scaphiocrinus) dactyliformis Hall, 1858c, p. 670, Pl. 17, fig.6. Bassler and Moodey, 1943, p. 605. 
Scaphiocrinus dactyliformis (Hall, 1858). Shumard, 1868, p. 395. Miller, S. A., 1889, p. 279.

Keyes, 1894a, p. 211, P1. 26, fig. 2. Weller, S., 1898c, p. 542. Bassler and Moodey, 1943, p. 605.

Phacelocrinus dactyliformis (Hall, 1858). Kirk, 1940c, p. 329. Bassler and Moodey, 1943, p. 605. Moore and Laudon, 1944, p. 171, Pl. 60, fig. 7. Webster, 1973, p. 204.

Diagnosis.--Cup globose, stout first primibrachial, usually single but can have a second primibrachial fused to the first; secundibrachials are stout proximally and remain in lateral contact as a pair along arm branches from two to five plates; brachial plates are subcuneate to rectangular rather than cuneate as represented in the original drawing by Hall (1858).

Materials examined.--The following were examined: FMNH-9636 and 13101 for a total of three specimens; INSM 71.1.9428, 71.1.9430, 71.1. 9431, 71.1.9439, 71.1.9501, 71.1.9504, 71.1.9506, 71.1.9509, 71.1.9516. and 71.1.9522 for a total of ten specimens; and USNM-S, 2639 with four specimens including plastotype.

Discussion.--The cups on all the FMNH specimens were not intact but did appear globose, contrary to Phacelocrinus vanhornei. This identification is based on the stout appearance of the primibrachials and the secundibrachials. The stem is present on two specimens and although appearing grossly round, on close scrutiny reveals a sub-pentagonal shape on end view.

Occurrence.--St. Louis Limestone, Missouri. 

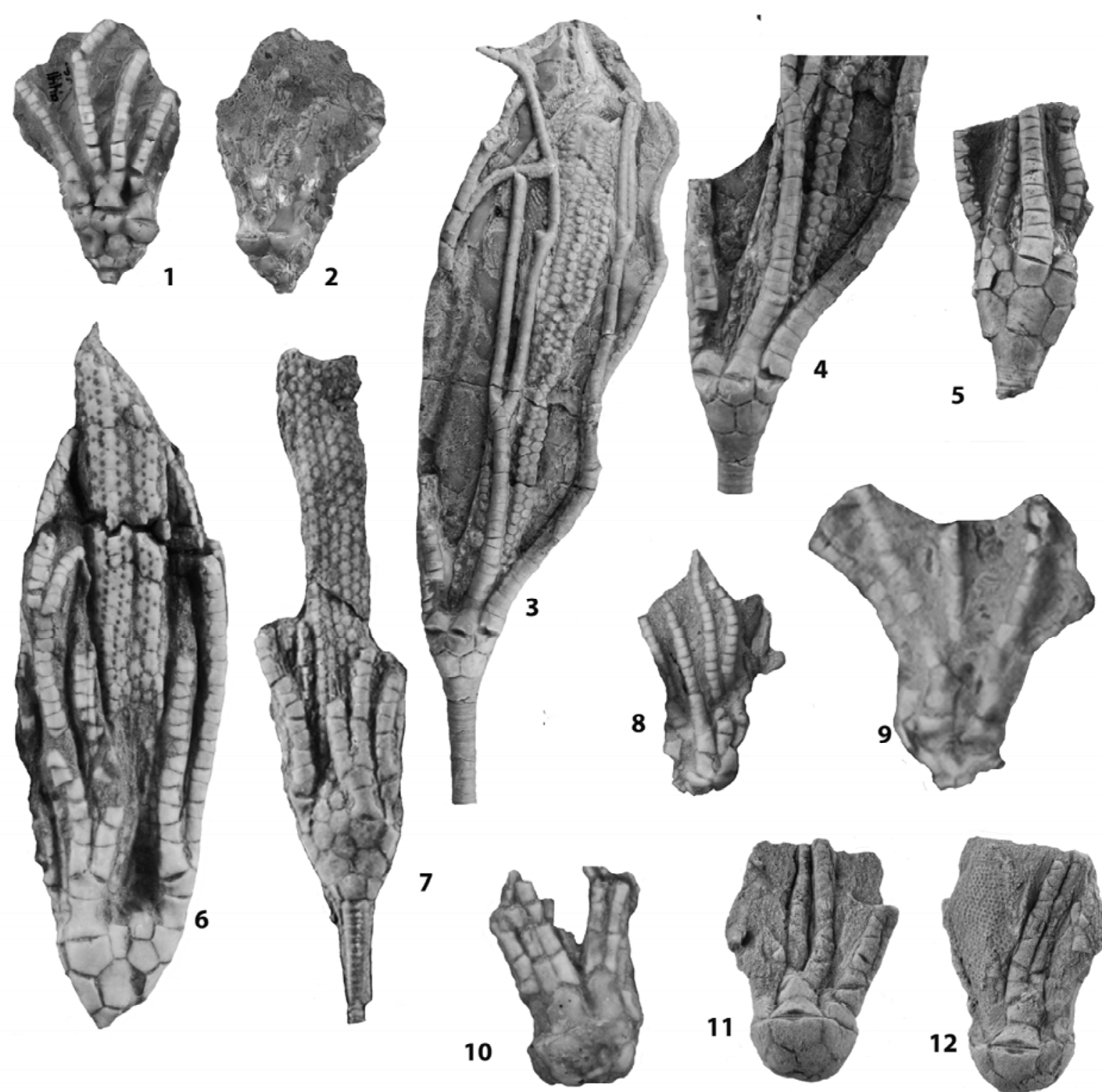

Figure 20. Advanced Cladids of the St. Louis Limestone. 1,2, Aphelecrinus scoparius (Kirk, 1944), ant. and post. view, FMNH, 9441, X1.0; 3-5, Culmicrinus missouriensis (Shumard, 1857), FMNH 7999, ant. view, X0.75; closeup view, X1.0; post. view, FMNH 10934, X1.0; 6, 7, Phacelocrinus vanhornei (Worthen, 1875), holotype, FMNH 6602, X2.0, Phacelocrinus arrectarius (Miller and Gurley, 1886), holotype FMNH 9858, X1.5; 8-10, Phacelocrinus dactyliformis (Hall, 1858), INSM 71.1. 9501, X1.0, INSM 71.1.9506, X1.5, FMNH 13101, X3.0; 11,12, Cymbiocrinus dactylus (Hall, 1859), Cyathocrinites macadamsi (Miller and Gurley, 1895), cotype, Cincinnati Museum 3841, ant.,X1.5, post. X1.5. 


\section{Phacelocrinus VANhornei (Worthen, 1875)}

Figure 20.6, 20.7

Poteriocrinus vanhornei Worthen, 1875, p. 517, Pl. 31, figs. 2-3. Miller, S. A., 1889, p. 275. Weller, S., 1898c, p. 559.

Poteriocrinus (Scytalocrinus) vanhornei Worthen, 1875. Wachsmuth and Springer, 1880 (1879), p. $118(341)$.

Scytalocrinus vanhornei (Worthen, 1875). Keyes, 1894a, p. 213, P1. 26, fig. 3. Weller, S., 1898 c, p. 559.

Phacelocrinus vanhornei (Worthen, 1875). Kirk, 1940c, p. 330. Bassler and Moodey, 1943, p. 606. Moore and Laudon, 1944, p. 171, P1. 60, fig. 5. Webster, 1973, p. 204.

Poteriocrinus arrectarius Miller and Gurley, 1896b, p. 33, Pl. 4, fig. 2. Miller, S. A., 1897, p.751. Weller, S., 1898c, p. 472.

Poteriocrinites arrectarius (Miller and Gurley, 1896). Bassler and Moodey, 1943, p. 638.

Diagnosis.--First primibrachial elongated with medial constriction; second primibrachial, axillary; anal sac, $4.8 \mathrm{~cm}$. with cup $0.8 \mathrm{~cm}$. high, more than the $4: 1$ ratio anal sac to cup ratio described for the genus; distinguished by anal sac structure of very regularly arranged hexagonal plates and pores penetrating the margins; arms do not branch a second time, at least within the 33 brachials present in the type specimen.

Materials examined.--The following were examined for Phacelocrinus vanhornei: eleven specimens including the type specimen, FMNH 9858 along with 9460, 10932, 10933, and 12990 (seven specimens within this museum number); twenty-four specimens from USNM, S-2639. For Poteriocrinus arrectarius, FMNH UC 6602 (its type specimen) was examined. 
Discussion.--It is noted that all of the Phacelocrinus vanhornei specimens identified in this study were from the collections of the FMNH and USNM-S, from the western Illinois Basin. None were identified in the collection housed at the Indiana State Museum from the eastern Illinois Basin. The only apparent differentiating character for Phacelocrinus vanhornei is the longer anal sac compared to the other Phacelocrinus species. From inspection of the holotype of Poteriocrinites arrectarius it is identical in morphology to Phacelocrinus vanhornei. As a result Phacelocrinus arrectarius is placed in synonymy with Phacelocrinus vanhornei herein. The older designation is Phacelocrinus vanhornei, Worthen, 1875. By the "law of priority," that name will be used for Poteriocrinites arrectarius.

Occurrence.--According to Webster (2003) Phacelocrinus vanhornei occurred during the Meramecian-Chesterian Series in the St. Louis Limestone and in the Ste. Genevieve Limestone in Illinois.

Family BLOTHCRINIDAE Moore and Laudon, 1943

Genus Culmicrinus Jaekel, 1918

Type species.--Poteriocrinus regularis Meyer, 1858, p. 119.

Diagnosis.--Crown high and conical; cup tall, conical; infrabasals, prominent, flaring up, pentagonal; basals flare up slightly, hexagonal; radials pentagonal, gaping plenary facets; three anal plates; radianal in contact with $\mathrm{BC}$ and $\mathrm{CD}$ basals; radianal and anal $\mathrm{X}$ between the 
radials, right tube plate contacts the D radial; anal sac long and slender, anal opening anterior side just above arm bases; anal sac plates small and vertically arranged in parallel rows; arms are uniserial brachials, well rounded, typically first branching above primibrachial two; Aray branches much higher than the others, for example, primibrachials number 27 in one well preserved specimen; second isotomous division half-way up the crown, third isotomous branching may be present on distal arms of large complete specimens; arm plates subcuneate; column round.

Discussion.--Culmicrinus has 12 species listed in Webster (2003). It occurred from the Famennian through the Visean in Europe, and from the Kinderhookian through the Chesterian in the United States.

Culmicrinus Missouriensis Shumard, 1857

Figure 20.3- 20.5

Poteriocrinus longidactylus Shumard, 1855 (homonym of Poteriocrinus longidactylus, Austin and Austin, 1847), p. 188, Pl. B, figs. 5a-5c; 1868, p. 391. Weller, S., 1898c, p. 545 .

Poteriocrinus missouriensis Shumard, 1857, p. 80. Shumard, 1868, p. 391. Miller, S. A., 1889, p. 274, Fig. 405. Weller, S., 1898c, p. 545. Bassler and Moodey, 1943, p. 383. Scaphiocrinus missouriensis (Shumard, 1857). Keyes, 1894a, p. 211, P1. 26, fig. 2. Weller, S., 1898c, p. 545. 
Culmicrinus missouriensis (Shumard, 1857). Springer, 1926b, p. 74, Pl. 18, fig. 3.

Bassler and Moodey, 1943, p. 383. Moore and Laudon, 1944, p. 159, Pl. 59, fig. 6. Ubaghs, 1953, p. 692, Fig. 33, no. k. Webster, 1973, p. 91.

Diagnosis.--Key character is the even flaring of the tapered cup and upper column, whereas other species of Culmicrinus have a more abrupt column-to-cup junction; proximal facet on each basal a convex curve where it articulates with the underlying infrabasals, previously published plate diagrams portray a sharp angle on the lower junction between the basals and infrabasals; height-to-width ratio of each basal plate 1:1.

Material examined.--The following were examined: five specimens, FMNH UC7999, UC9451 (a juvenile) and UC10934; fourteen specimens, INSM, 71.1.9456 through 71.1.9464; and forty specimens from USNM-S-2639.

Discussion.--Culmicrinus missouriensis appears to be relatively abundant based on the number of specimens in collections from the St. Louis Limestone. The characters that differentiate it from the others in its genus include higher branching arms, a possible change in the facets of the lower edge of the basals resulting in a more evenly tapered stem-to-cup transition. The first division of the arms is higher than Culmicrinus elegans (Wachsmuth and Springer, 1897). C. elegans was later synonymized into Culmicrinus vagulus (Miller and Gurley, 1895) by Springer (1926). Its first division was less than ten primibrachials. The first division of C. missouriensis is above ten primibrachials (Chestnut and Ettensohn, 1988). The stem is round, differentiating it from C. thomasi (Laudon, 1933), which is the only species of Culmicrinus with a "subpentagonal" stem (Moore and Laudon, 1943).

Occurrence.--St. Louis Limestone, Alton, Illinois and Bainbridge, Indiana. 
Genus Stinocrinus Kirk, 1941

Type specimen.--Stinocrinus granulosis Kirk, 1941, p.84.

Diagnosis.--Crown medium height, subcylindrical; cup low, bowl shaped; infrabasals small, not visible in side view; basals $1 / 2$ height of radials, pentagonal; radials pentagonal, gaping plenary facet; three anals in cup; two primibrachials except for A-ray which has nine; arms isotomous branching, brachials rectangular to subcuneate, one to three bifurcations per ray; column obscurely pentagonal.

Discussion.--Stinocrinus has one species listed in Webster (2003). It occurred during the Osagean of Kentucky of the United States.

\section{StinOcRinUs s.p.}

Figure 21.4 (Stinocrinus s.p. in figure, not S. granulosus)

Material examined.--The following were examined: three specimens from INSM, 71.1.9443, 71.1.9492, and 71.1.9524.

Discussion.--Stinocrinus granulosus has only been recognized in the Osagean. Placing it in the St. Louis must be done with caution. The one absolutely distinguishing characteristic of an atomous A-ray for this species cannot be verified in these available specimens because the A-ray is not visible. It could be a different species. In that case it would be labeled as Stinocrinus? s.p.

Occurrence.--New Providence Shale Member of the Borden Formation, Kentucky and possibly St. Louis Limestone, Bainbridge, Indiana. 
Family APHeLECRINIDAE Strimple, 1967

Genus Aphelecrinus Kirk, 1944

Type species.--Aphelecrinus elegans Kirk, 1944, p.190.

Diagnosis.--Crown high; cup conical; infrabasals pentagonal and 1/3 height of basals; basals hexagonal, height to width ratio of 1:1; radials pentagonal, plenary facet with primibrachial slightly gaping; three anal plates; radianal in contact with $\mathrm{BC}$ and $\mathrm{CD}$ basals; radianal and anal $\mathrm{X}$ between radials; right tube plate contacts the $\mathrm{D}$ radial; anal sac extends $1 / 2$ the height of the arms, vertical rows of polygonal plates; single primibrachial, brachials cuneate; arms uniserial with isotomous branching at primibrachial one, second branching typically occurs at $1 / 3$ to $1 / 2$ the height of the arms, some species have no further divisions above the initial proximal division (Kirk, 1944); stem circular with pentagonal lumen.

Discussion.--Aphelecrinus has 25 species listed in Webster (2003). It occurred in Western Europe and Scotland during the Visean and Tournaisian (Kammer and Ausich, 2007). In the United States it occurs from the Kinderhookian through the Chesterian. 


\section{ApHELECRINUS SCOPARIUS Hall, 1858}

Figure 20.1, 20.2

Scaphiocrinus scoparius Hall, 1858c, p. 680, P1. 25, figs. 3a-3b; Fig. 108. Miller, S. A., 1889, p. 280. Weller, S., 1898c, p. 548.

Pachylocrinus scoparius (Hall, 1858). Springer, 1926, Bassler and Moodey, 1943, p. 584. Aphelecrinus scoparius (Hall, 1858). Kirk, 1944c, p. 200. Webster, 1973, p. 56.

Poteriocrinus clytis Worthen, 1882, p. 16; 1883, p. 294, Pl. 30, fig. 10. Miller, S. A.,1889, p.

273. Weller, S., 1898c, p. 474. Bassler and Moodey, 1943, p. 639, 643.

Poteriocrinus peculiaris Worthen, 1883, p. 298, P1. 29, fig. 10. Miller, S. A., 1889,

p. 275. Bassler and Moodey, 1943, p. 643. Kirk, 1944c, p. 202. Webster, 1973, p. 56.

Poteriocrinites peculiaris (Worthen, 1883). Bassler and Moodey, 1943, p. 643.

Aphelecrinus peculiaris (Worthen, 1883). Kirk, 1944c, p. 202. Webster, 1973, p. 56.

Diagnosis.--Small size; elongate primibrachial, parallel sides of the primibrachial; brachials have obviously larger secundibrachials than tertibrachials.

Material examined.--The following were examined: for Aphelecrinus scoparius, one specimen from FMNH UC 9436; for A. peculiaris FMNH UC 9441 and INSM, 71.1.9427.

Discussion.--Aphelecrinus scoparius is the only other species, besides A. peculiaris, of this genus to be listed in the St. Louis Limestone. Originally, Worthen (1882) named two different specimens by the same name, Poteriocrinus clytis “by error” (Webster, 2003). Worthen (1883) corrected that error by renaming the specimen from the Chester Limestone in Monroe County, Illinois, Poteriocrinus peculiaris. Kirk (1944) reassigned Poteriocrinus peculiaris, Aphelecrinus pecularis and placed Poteriocrinus clytis in 
synonymy with it as well. On comparing the two species, A. scoparius and A. peculiaris appear to be morphologically identical. As a result, A. peculiaris is placed in synonymy with A. scoparius. By the "law of priority," Aphelecrinus scoparius will be the assigned name.

Occurrence.--St. Louis Limestone, Chesterian Limestone, Illinois and Bainbridge, Indiana.

Superfamily LOPHOCRINACEA Bather, 1899

Family Pachylocrinidae Kirk, 1942

Genus Pachylocrinus Wachsmuth and Springer, 1880

Type species.--Scaphiocrinus aequalis Hall, 1861, p. 8.

Diagnosis.--Crown tall, cylindrical; cup low, bowl shaped, concave base; infrabasals not visible from side; basals hexagonal, large, equal height-to-width ratio, smooth; radials pentagonal, peneplenary facet; three anal plates, radianal contacts two basals and D radial, anal $\mathrm{X}$ contacts top of basal and $\mathrm{C}$ radial, right tube plate atop radianal and contacts $\mathrm{D}$ radial; two primibrachials, branching isotomously, brachials cuneate, two to three bifurcations above the primibrachials resulting in as many as 40 branches in the upper crown; pinnules long and slender; anal sac tall, cylindrical and composed of small polygon plates; stem round or pentagonal.

Discussion.--Pachylocrinus has 27 species listed in Webster (2003). It occurred from the Famennian to the Moscovian in China, Europe and Russia. During the Kinderhookian to the Chesterian, it occurs in the United States. However, many of these species assigned to Pachylocrinus are in need of taxonomic revision. Kammer and Ausich (1993, p. 619) discussed how Bassler and Moodey (1943) used Pachylocrinus as a repository for many 
species of morphologically dissimilar advanced cladids. Future taxonomic work will probably place most of these in different genera.

Pachylocrinus noRwoodi Meek and Worthen, 1865

Poteriocrinus (Scaphiocrinus)? norwoodi Meek and Worthen, 1865c, p. 158. Shumard, 1868, p. 392 .

Poteriocrinus norwoodi Meek and Worthen, 1865. Miller, S. A., 1889, p. 275.

Pachylocrinus norwoodi (Meek and Worthen, 1865). Bassler and Moodey, 1943, p. 582.

Material examined.--None.

Discussion.--This species is consistently listed as occurring in the St. Louis Limestone. Meek and Worthen's (1865) description is the only information available on the morphology. No drawing or photograph is known to exist for this species. Until shown otherwise, Pachylocrinus norwoodi will be listed as being in the St. Louis Limestone; however, no examples can be accurately identified. It must be noted that this species is an unconfirmed species for the St. Louis Limestone and is considered a nomen dubium.

Occurrence.--St. Louis Limestone, Illinois.

Superfamily Agassizocrinacea S. A. Miller, 1889

Family Ampelocrinidae Kirk, 1942

Genus Armenocrinus Strimple and Horowitz, 1971

Type species.--Armenocrinus watersi Strimple and Horowitz, 1971. p. 23. 
Diagnosis.--Crown expanding cone shaped; cup bowl shaped with slight convex base; infrabasals

visible from side view; basals hexagonal, radials pentagonal with peneplenary, gaping facet; single anal plate atop the C-D basal; primibrachials two to five in number tapering inward toward the axillary; usually 10 arms, long pinnules on opposite sides alternating; column round to sub-pentagonal.

Discussion.--The genus description by Strimple and Horowitz (1971) was made on the basis of known species at that time. The addition of the new species (below) here will expand that description somewhat. Specifically, their original designation of two to four primibrachials will be expanded to two to five, and a more bowl-shaped cup with a slightly convex base will be added. Armenocrinus has three species listed in Webster (2003). It occurred in Indiana and Alabama from the Osagean through the Meramecian.

Armenocrinus howelli, n. sp.

Figure 21.5a, 21.5b, 21.4

Diagnosis.--A species of Armenocrinus with five primibrachials.

Description.--Crown urn shaped; cup bowl shaped with slight convex base, plates smooth, wide sutures between plates; five infrabasals, $2.0 \mathrm{~mm}$ high and $3.0 \mathrm{~mm}$ wide; basals hexagonal, $3 \mathrm{~mm}$ high and $3.2 \mathrm{~mm}$ wide; radials pentagonal, $2.5 \mathrm{~mm}$ high and $3.0 \mathrm{~mm}$ wide, facet peneplenary to plenary, slightly gaping; single anal (radianal) rectangular and resting on the full width of the superior facet of the C-D basal; five primibrachials, the first and second narrow quickly into what results in narrow, branching arms; the longest arm in this specimen 
(type specimen, figure 5.5a) contains eight secundibrachials without further branching, brachials rectangular to slightly cuneate, pinnules long and slender; column round, alternating thick nodals and thinner internodals.

Etymology.--This name recognizes Robert Howell who collected and prepared a large selection of many fine specimens of crinoids over numerous years in Indiana. He also collected and prepared the group of specimens from the Harris Stone Quarry in Bainbridge, Indiana, that is clearly within the St. Louis Limestone, including those that are housed in the Indiana State Museum.

Material examined.--The following were examined: five specimens from the INSM, 71.1.9519, 71.1.9520, 71.1.9521, 71.1 9526, 71.1 9528. Specimen slab 71.1.9521 contains two fossils, designated fossil $\underline{\mathbf{a}}$ and fossil $\underline{\mathbf{b}}$, that appear identical; the others are single fossils. Two specimens are from USNM S-2639.

Types.--The holotype fossil for this new species is 71.1 .9521 a (Fig. 5.5a) in the Indiana State Museum. INSM specimens 71.1.9519 (Figure 5.6), 71.1.9520, 71.1.9521b (Figure 5.5b), 71.1.9526 and 71.1.9528 will be paratypes.

Discussion.--The cup of Armenocrinus howelli n. sp. resembles that of Armenocrinus watersi in its bowl shape. The arms are closer in configuration to Armenocrinus neglectus, which has four primibrachials. Five of the specimens of Armenocrinus howelli are from the same site (the Harris Stone Quarry at Bainbridge, Indiana, collected by Robert Howell) and appear to be identical in size and morphology. Two specimens are from St. Louis, Missouri, in the Springer Collection at the Smithsonian.

Occurrence.--St. Louis Limestone, St. Louis, Missouri, and Bainbridge, Indiana. 
Superfamily PiRAsocrinaceA Moore and Laudon, 1943

Family PiRAsocrinidae Moore and Laudon, 1943

Genus Plaxocrinus Moore and Plummer, 1938

Type species.--Hydreionocrinus crassidiscus Miller and Gurley, 1894, p. 43

Diagnosis.--Crown moderately tall, cylindrical; cup bowl shaped, depressed base; infrabasals within convexity; basals pentagonal, minimally seen from side view; radials convex, peneplenate, gaping facet; three anal plates in cup, radianal contacts D radial and CD basal, anal $\mathrm{X}$ contact $\mathrm{C}$ radial and the upper point of the $\mathrm{CD}$ basal, right tube plate contacts the anal $\mathrm{X}$ and the upper D radial; single primibrachial; arms isotomous branching, rectangular to subcuneate brachials, four to six secundibrachials before second bifurcation; primibrachials spine bearing; column round.

Discussion.--Plaxocrinus has 23 species listed in Webster (2003). In the United States it occurred from the Morrowan to the Wolfcampian. In Brazil it is middle Pennsylvanian. These formations listed by Webster (2003) are not consistent with the stated St. Louis Limestone occurrence for Plaxocrinus sanctiludovici. Webster does question the designation of Plaxocrinus as the genus for this species but does not suggest an alternative.

Plaxocrinus SANCTILUdovici, Worthen, 1889

Eupachycrinus? sancti-ludovici Worthen in Miller, S. A., 1889, p. 356. Worthen, 1890, p.

98. Weller, S., 1898c, p. 311.

Eupachycrinus sanctiludovici Worthen in Miller, S. A., 1889, p. 245; 1897, p. 746. 
Hydreionocrinus sancti-ludovici (Worthen, 1889). Miller and Gurley, 1893, p. 40, Pl. 6, fig.

2. Weller, S., 1898c, p. 311.

Hydreionocrinus sanctiludovici (Worthen, 1889). Miller, S. A., 1897, p. 747.

Plaxocrinus?? sanctiludovici (Worthen, 1889). Moore and Plummer, 1940, p. 356. Bassler

and Moodey, 1943, p. 634. (Not a Plaxocrinus, GDW.)

Diagnosis.--Short strong spine on primibrachial.

Material examined.--INSM 71.19511.

Discussion.--This species may be particularly difficult to properly define. Miller and

Gurley (1893) stated that Worthen's description was "very fragmentary" and an "imperfect description." Miller and Gurley "supposed it to belong to the genus Hydreionocrinus."

Webster labeled it "Not a Plaxocrinus, GDW." No clear description or diagram can be found for this species. Given the unclear morphological delineation and the lack of a type specimen, this species will be disregarded at this time.

Occurrence.--Probably not St. Louis Limestone, Missouri.

Superfamily TeXacrinacea Strimple, 1961

Family Cymbiocrinidae Strimple and Watkins, 1969

Genus Cymbiocrinus Kirk, 1944

Type species.--Cymbiocrinus romingeri Kirk, 1944, p. 233.

Diagnosis.--Crown medium height; cup bowl shaped with flat base, depressed at columnar junction; infrabasals small, in base but extends beyond column; basals nodose, pentagonal, radials pentagonal, $2 / 3$ height of cup; single anal, radianal, between radials and in contact with 
basal, facet plenary and gaping; two primibrachials with isotomous, uniserial branching; brachials subcuneate, two per ray with no further branching; pinnules; anal sac tall; column round, pentagonal lumen, whorls of cirri.

Discussion.--Cymbiocrinus has six species listed in Webster (2003). It occurs from the Meramecian to the Morrowan in the United States. It questionably occurred during the Visean, of Western Europe (Kammer and Ausich, 2007).

Cymbiocrinus dactylus Hall, 1859

Figure 20.11, 20.12

Graphiocrinus dactylus Hall, 1859a, p. 80. Meek and Worthen, 1873, p. 559, P1. 20, fig. 9. Miller, S. A., 1889, p. 251. Weller, S., 1898c, p. 558.

Poteriocrinus (Scytalocrinus) dactylus (Hall, 1859). Wachsmuth and Springer, 1880 (1879), p. $117(340)$.

Scytalocrinus dactylus (Hall, 1859). Weller, S., 1898c, p. 558. Bassler and Moodey, 1943, p. 677.

Cymbiocrinus dactylus (Hall, 1859). Kirk, 1944d, p. 237. Webster, 1973, p. 97. Burdick and Strimple, 1983a, p. 147. Webster, 1988, p. 66.

Cyathocrinites macadamsi (Miller and Gurley, 1895), p. 69, Pl. 4, figs. 31-32. Miller, S. A., 1897, p. 741. Weller, S., 1898c, p. 201. Bassler and Moodey, 1943, p. 392. Webster, 2003, p. 745.

Diagnosis.--Cup bowl shaped, depressed base; infrabasals small and barely visible, basals slightly nodose, pentagonal; radials pentagonal, facet plenary, moderately gaping; two 
primibrachials, first larger than the second; ten arms, slightly to strongly cuneate, stout pinnules off axillary shaped brachials.

Material examined.--The following were examined: four specimens, INSM 71.1.9427, 71.1.9488, 71.1.9490, 71.1.9491; 15 specimens, USNM S-2639; three specimens from the University of Cincinnati Museum; holotype, number 3841, and two cotypes, number 3842, of Cyathocrinites macadamsi.

Discussion.--The morphological differences between Cymbiocrinus dactylus of the St. Louis and Cymbiocrinus grandis of the Ste.Genevieve is not striking. Kirk described $C$. grandis as being "the largest known" of Cymbiocrinus. All of the specimens in the collection at the USNM-S have much smaller cups. Of the 12 with measurable cups, the range of width is $5-10 \mathrm{~mm}$. The cup widths of Kirk's holotype and paratypes are 13 to $15 \mathrm{~mm}$. He also describes its plates as being "convex, but not notably so" and the brachials as being "more cuneate than in any other described species" (Kirk, 1944). In reviewing all of the specimens and the figures provided by Kirk (1944), the brachial sutures are exceedingly variable even within the same specimen. A specific trend in the suture angles is not obvious. The distinction of this being a separate species would be of concern if persistence of Cymbiocrinus dactylus into the Ste. Genevieve were important. Considering that C. grandis is only listed for the Ste. Genevieve Limestone, the issue will not be pursued here.

The drawing of Cymbiocrinus provided by Meek and Worthen (1873) does not appear to be within the genus. Cymbiocrinus has only one anal plate; their drawing has two anal plates far down into the cup. Kirk (1944) disputed that figure as being from the St. Louis Limestone and proposes that it "may be a distinct species." As a result, Meek and Worthen's depiction 
of this specimen should be ignored.

Cyathocrinites macadamsi, Miller and Gurley, 1895--This species is not Cyathocrinites because it lacks a horseshoe-shaped facet (angustary). The figure by Miller and Gurley (1895) shows a full-width plenary facet. The drawing by Miller and Gurley (1895) is consistent with the genus Cymbiocrinus. In fact, Kirk (1944d) previously synonymized Cyathocrinus macadamsi with Cymbiocrinus dactylus Hall, 1859, which Webster did not note.

Occurrence.--St. Louis Limestone and Hartselle Sandstone, Alabama, Missouri and Illinois.

Family StaphyLocrinidae Moore and Strimple, 1973

Genus Dinotocrinus Kirk, 1941

Type species.--Dinotocrinus compactus Kirk, 1941, p. 513

Diagnosis.--Crown urn to cylindrical shaped; cup bowl shaped, base convex; infrabasals small and concealed by proximal column; basals hexagonal, nodose; radials pentagonal, ratio height to width, 2:3, plenary facets slightly gaping; single primibrachial (axillary); arms with isotomous branching, rectangular to slightly cuneate brachials, branching once or twice, 5 to 10 secundibrachials; pinnules long and stout; anal sac short, slender and reflexed; column circular with prominent nodals and intermodal series.

Discussion.--Dinotocrinus has nine species listed in Webster (2003). It occurred in the Early Carboniferous in England and Ireland, and from the Kinderhookian through the Chesterian it occurs in North America. 


\section{DinOtocrinus SALTERI Worthen, 1882}

Figure 21.1, 21.2

Poteriocrinus salteri Worthen, 1882, p. 21; 1883, p. 291, P1. 29, fig. 18

Scaphiocrinus salteri (Worthen, 1882), Wachsmuth and Springer, 1886, p. 236 (160).

Miller, S. A., 1889, p. 280. Weller, S., 1898c, p. 548.

Dinotocrinus salteri (Worthen, 1882). Kirk, 1941a, p. 514. Bassler and Moodey, 1943, p. 428.

Diagnosis.--The primary difference distinguishing this species is its having only six secundibrachials, whereas other species have eight to ten.

Materials examined.--The following were examined: four specimens, INSM 71.1.9490, 71.1.9491, 71.1.9493 and 71.1.9525.

Discussion.--Dinotocrinus salteri is listed as occurring only in the Chesterian by Webster (2003) and Bassler and Moodey (1943). Webster gave the range of the genus Dinotocrinus as being Kinderhookian through Chesterian. He listed Dinotocrinus salteri in Alabama and Illinois while excluding Indiana, the source of the specimens examined here. Given this new occurrence, Dinotocrinus salteri will be added to the St. Louis Limestone in Indiana.

Occurrence.--St. Louis Limestone in Bainbridge Indiana and Ste. Genevieve Limestone in Alabama and Illinois. 
Order FLeXIBILIA Zittel, 1895

Suborder TAXocRINIDA Springer, 1913

Superfamily TaxocrinaceA Angelin, 1878

Family Taxocrinidae Angelin, 1878

Genus Taxocrinus Phillips in Morris, 1843

Type species.--Cyathocrinus macrodactylus, Phillips, 1841.

Diagnosis.--Crown subspherical to elongate; cup bowl shaped; infrabasals three, not seen, covered by column; basals pentagonal; radials horizontal, slightly U-shaped, height-to-width ratio of 1:2; basal at $\mathrm{CD}$ interray elongated vertically upon which the anal $\mathrm{X}$ is attached followed by one anal plate and the anal tube, interray exposure of a single vertical row of anal plates; three primibrachials; interprimibrachials filling between and contacting all three primibrachials configured in a triangle; isotomous, uniserial branching at the third primibrachial, third or fourth secundibrachial and fifth through eighth tertibrachial (three uneven bifurcations); brachials rectangular; column flares toward cup, round.

Discussion.--Taxocrinus has 32 species listed in Webster (2003). From the Eifelian through the Visean, it occurred in Europe. During the Givetian through the Chesterian, it occured in the United States.

TAXocrinus SHUMARDianus Hall, 1858

Figure 21.8

Forbesiocrinus shumardianus Hall, 1858c, p. 671, P1. 18, fig. 1. Shumard, 1868, p. 372.

Miller, S. A., 1889, p. 246. Weller, S., 1898c, p. 626. Bassler and Moodey, 1943, p. 704. Taxocrinus shumardianus (Hall, 1858). Wachsmuth and Springer, 1880 (1879), p. 49 (272). 
Weller, S., 1898c, p. 626. Springer, 1906, Pl. 7, fig. 17; 1920a, p. 382, P1. 59, figs. 13-16.

Bassler and Moodey, 1943, p. 704. Priest, 1970, p. 15, Fig. 6. Webster, 1977, p. 166.

Burdick and Strimple, 1983a, p. 201, P1. 25, figs. 1-2, 4-7, 10-11, 13. Webster, 1988, p. 300.

Taxocrinus shumardanus (Hall, 1858). Miller, S. A., 1889, p. 286.

Diagnosis.--Proximal plates of cup and arms very stout with arms tapering peripherally, the first bifurcation tapers more abruptly than in the other species of this genus; most proximal interprimibrachial contacts radial and the total interprimibrachials number three to ten; arms remain open throughout branching without contact between them.

Materials examined.--The following were examined: twelve specimens, INSM 71.1.9433, 71.1.9446, 71.1.9451, 71.1.9452, 71.1.9453, 71.1.9454, 71.1.9455, 71.1.9467, 71.1.9468, 71.1.9468, 71.1.9469, 71.1.9470, and71.1.9471; and twenty one specimens from USNM- S 2639.

Discussion.--Taxocrinus shumardianus appears to be relatively abundant within the St. Louis Limestone given the number preserved in the studied collection. This may be even more significant given the relative paucity diversity of flexibles as compared to the camerates and advanced cladids through the Meramecian.

Occurrence.--St. Louis Limestone, St. Louis, Missouri and Bainbridge, Indiana. 

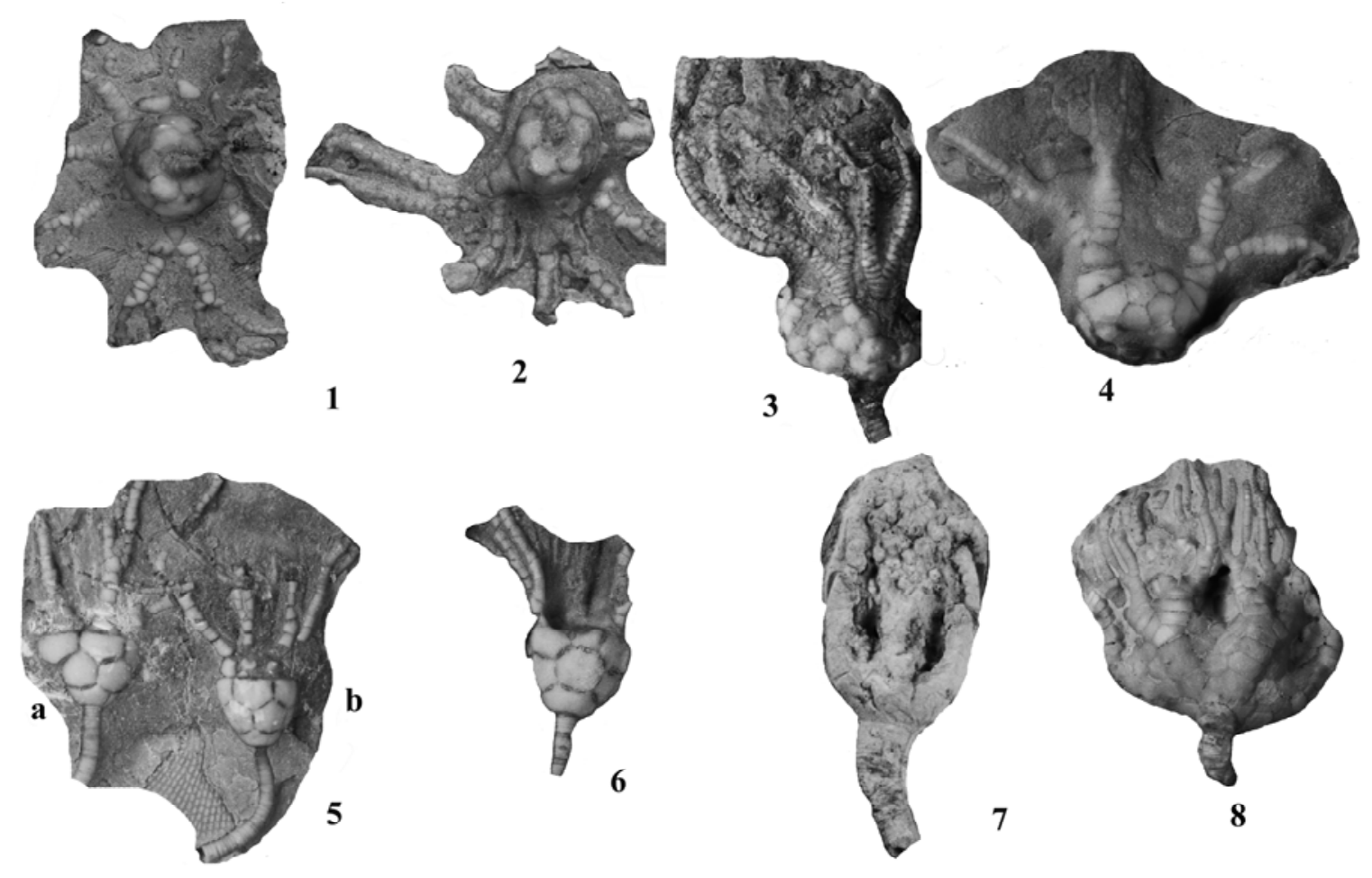

Figure 21. Crinoids added, not previously assigned to the St. Louis Limestone, plus St.

Louis flexibles. 1, 2, Dinotocrinus salteri (Worthen, 1882), INSM 71.1.9491, X1.5;

INSM 71.1.9490, X1.5; 3, Cribanocrinus coxanus (Worthen, 1882), INSM 71.19445, X2.0; 4, Stinocrinus sp. INSM 71.1.9443, X2.0; 5,6, Armenocrinus howelli, n. sp., INSM 71.1.9521a, type specimen and 71.1.9521b, paratype, X1.5, INSM 71.1.9519, paratype, X2.0; 7, Onychocrinus magnus (Worthen, 1875), USNM- S2639, X1.5; 8, Taxocrinus shumardianus (Hall, 1858), INSM 71.1.9454, X1.0.

\section{Family SynERocrinidaE Jaekel, 1918}

Genus Onychocrinus Lyon and Casseday, 1860

Type species.--Onychocrinus exsculptus Lyon and Casseday, 1860, p.77.

Diagnosis.--Crown subspherical to elongate; cup bowl shaped; three infrabasals, hidden 
under column attachment; basals pentagonal, originate at level of column insertion; radials flattened with height to width ratio of $1: 2$, slight U-shape, radial at CD interray elongated vertically to accommodate anal $\mathrm{X}$, one anal plate; anal tube single vertical row of plates, height unknown; four primibrachials; interbrachials, none to single prevail in specimens examined. Moore (1978) portrays a large number of interprimibrachials in his figures; arms isotomous branching at primibrachial, uniserial, rectangular brachials, no further branching resulting in ten arms; numerous ramules branch off both sides of the arms, each ramule branches up to five times, column round and flares outward toward its insertion.

Discussion.--Onychocrinus has 17 species listed in Webster (2003). It occurred during the Tournasian through the Visean in Europe and during the Osagean through the Chesterian in the United States.

ONYCHOCRINUS MAgNus Worthen, 1875

Figure 21.7

Onychocrinus magnus Worthen, 1875, p. 520, P1. 31, fig. 5. Miller, S. A., 1889, p. 265.Weller, S., 1898c, p. 387. Springer, 1920a, p. 421, P1. 73, figs. 1-4. Bassler and Moodey, 1943, p. 575. Burdick and Strimple, 1983a, p. 204, P1. 25, fig. 9. Webster, 1988, p. 118 .

Diagnosis.--Basals are unequal size, two on the anal side smaller (below the C-ray); fewer or no interprimibrachials may be a differentiating characteristic of Onychocrinus magnus since that is a difference seen between the genus description and the specimens examined; ramules alternate from side to side of each arm, terminal arms and ramules are not distinguishable; column round, gradually enlarging vertically, segments thin. 
Materials examined.--The following were examined: three specimens, USNM- S 2639. Discussion.--Onychocrinus magnus demonstrates relatively little apparent difference from Taxocrinus shumardianus. These two species share a common superfamily and the common environmental setting of deeper water. These unique features may be important in delineating the paleoecological setting for the St. Louis Limestone.

Occurrence.--St. Louis Limestone and Bangor Limestone in Illinois and Alabama. 


\section{$\underline{\text { Evolutionary Paleoecology }}$}

\section{Introduction}

Changes in the macroevolution of crinoids that occurred between the Osagean and the Chesterian have been described by crinoid workers over the last two decades. These changes include a transition in dominance from camerates to advanced cladids (Ausich et al., 1994), an early- to mid-Meramecian dip in the number of genera of crinoids (Kammer and Ausich, unpublished data) and some morphological changes such as anti-predatory structures.

Although some authors have suggested possible ecological influences on these changes such as facies changes, predation, sea level changes, habitat loss, autecology and species competition (Baumiller, 1993, 1994; Ausich et al., 1994; Kammer and Ausich, 2006), an integrated approach has not been undertaken to offer a full explanation. This study provides an updated description of the St. Louis stratigraphic boundaries and a modernized systematic study of St. Louis crinoids, and attempts to describe ecological influences on morphological changes..

\section{History of Crinoid Subclass Distribution}

Since the origin of crinoids in the Ordovician, the number of genera has varied widely (Broadhead and Waters, 1980; Baumiller and Messing, 2007) (Figure 22). The Paleozoic was the time of maximum diversity and abundance. Out of the six recognized subclassescamerates, disparids, primitive cladids (cyathocrines), advanced cladids (dendrocrines), flexibles and articulates — only the articulates survived the Permian extinction. The 
articulates evolved from the advanced cladids at the very end of the Paleozoic and survive in large numbers today (Hess, 1999).

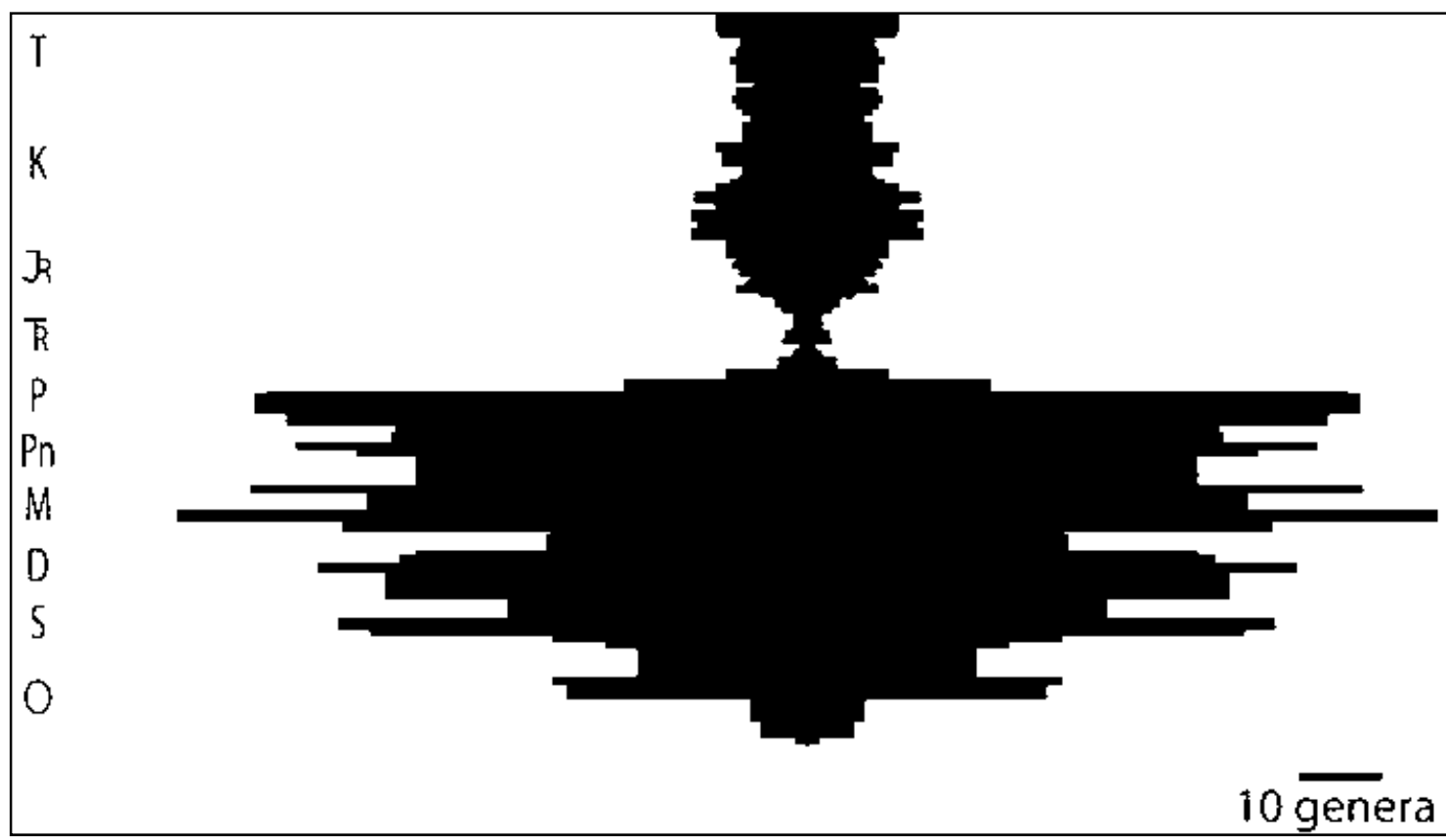

Figure 22. Numbers of crinoid genera throughout the Phanerozoic (adapted from Baumiller and Messing, 2007).

The first recognized crinoids occurred during the Ordovician (Ubaghs, 1978; Guensburg and Sprinkle, 2001, 2003, 2009). Guensberg and Sprinkle (2003) have recently described two genera of Early Ordovician "protocrinoids" that were somewhat irregular in their morphology as compared to later crinoids, but represent the stem group from which the Paleozoic subclasses originated. An earlier crinoid-like organism, Echmatocrinus, from the Burgess Shale has been discussed in the literature as the oldest possible example of a crinoid, but it remains controversial (Simms et al., 1993; Ausich and Babcock, 1996; Sprinkle and Collins, 1998). Current opinion considers Echmatocrinus to be an octocoral and not a crinoid (Ausich and Babcock, 2000). It should be pointed out that crinoid ancestors must have 
occurred prior the Ordovician. The advanced stage of development of those specimens found from the Early Ordovician indicates a long history of development (Ubaghs, 1978; Simms, 1999).

The earliest groups of crinoids were camerates, and then primitive cladids, followed within a short time by disparids. Four of the five major Paleozoic crinoid groups--camerates, primitive cladids, disparids, and flexibles--were present by the end of the Ordovician (Ubaghs, 1978; Ausich, 1998). Recent work by Sprinkle, et al., (2008) revealed that representatives of the Paleozoic crinoids, except for flexibles, were present in the Early Ordovician. These included diplobathrid camerates, monobathrid camerates, cladids, and disparids. It was noted by Lane (1971) that during the Ordovician both clastic and carbonate environments contained an equal proportion of camerates and inadunates (primitive cladids and disparids). This distribution changed in the Middle Silurian to a higher number of camerates in both settings. In the Upper Devonian, camerates were predominant in carbonate environments, whereas inadunates (sensu Moore, 1978) were more abundant in terrigenous settings (Lane, 1971). Following the Late Devonian Frasnian-Famennian extinction event and continuing into the Mississippian, crinoids increased in both diversity and abundance (Figure 23). The number of crinoids increased from approximately 50 to 100 genera per stage during the Devonian to 100-170 genera per stage during the Mississippian. Encrinites (crinoidal limestones) were very thick and widespread globally during the Mississippian (Ausich, 1997; Kammer and Ausich, 2006). This trend peaked in the Visean (Middle Mississippian) stage with a change in proportion of crinoids that reflected an increase in diversity of both the advanced cladids and the camerates (Figure 23A). The disparids, 
flexibles and primitive cladids did not exhibit the same increase in diversity (Kammer and Ausich, 2006).

During the Middle Mississippian, advanced cladids caught up with camerates in diversity, and exceeded them, from the Late Mississippian through the end of the Paleozoic (Kammer and Ausich, 2006); (Figure 23). Their abundance both in actual numbers and in diversity increased during the Mississippian. The decline in the relative proportion of camerates to the advanced cladids is shown in part $\mathrm{C}$ of Figure 23. Representatives of the five groups of crinoids are shown in Figure 24.

The dominance of advanced cladids continued throughout the remainder of the Paleozoic, although there was a decline in the total number of taxa of crinoids in the Late Permian (Figure 22). The Permian extinction event marked the end of the Paleozoic crinoids and the beginning of modern-day articulates (Simms, 1999). 


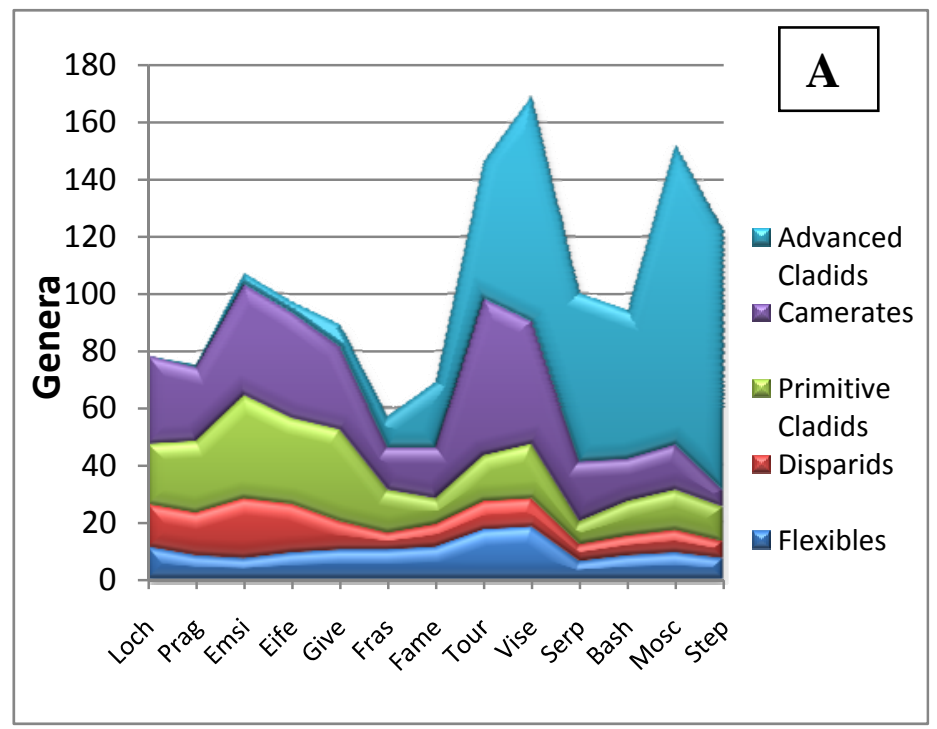

Figure 23. Variation in the diversity of crinoids through time.

A. Variation in the number of crinoid genera.

B. Relative proportion of the groups.

C. Proportion of camerates to advanced cladids.

Devonian includes LochkovianFamennian; Mississippian includes Tournaisian- Serpukhovian; Pennsylvanian includes BashkirianStephanian. (Kammer and Ausich, 2006, Figure 1).
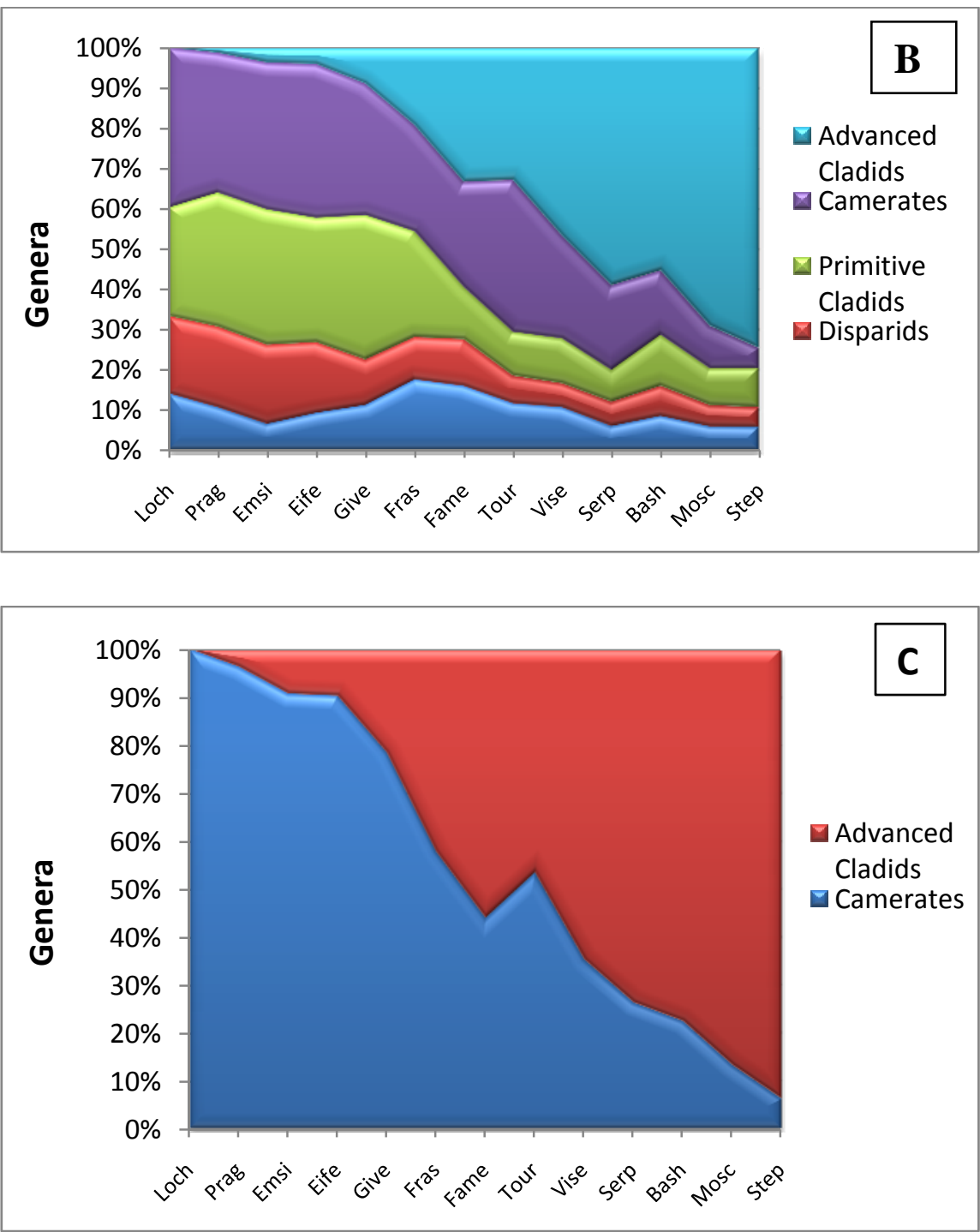


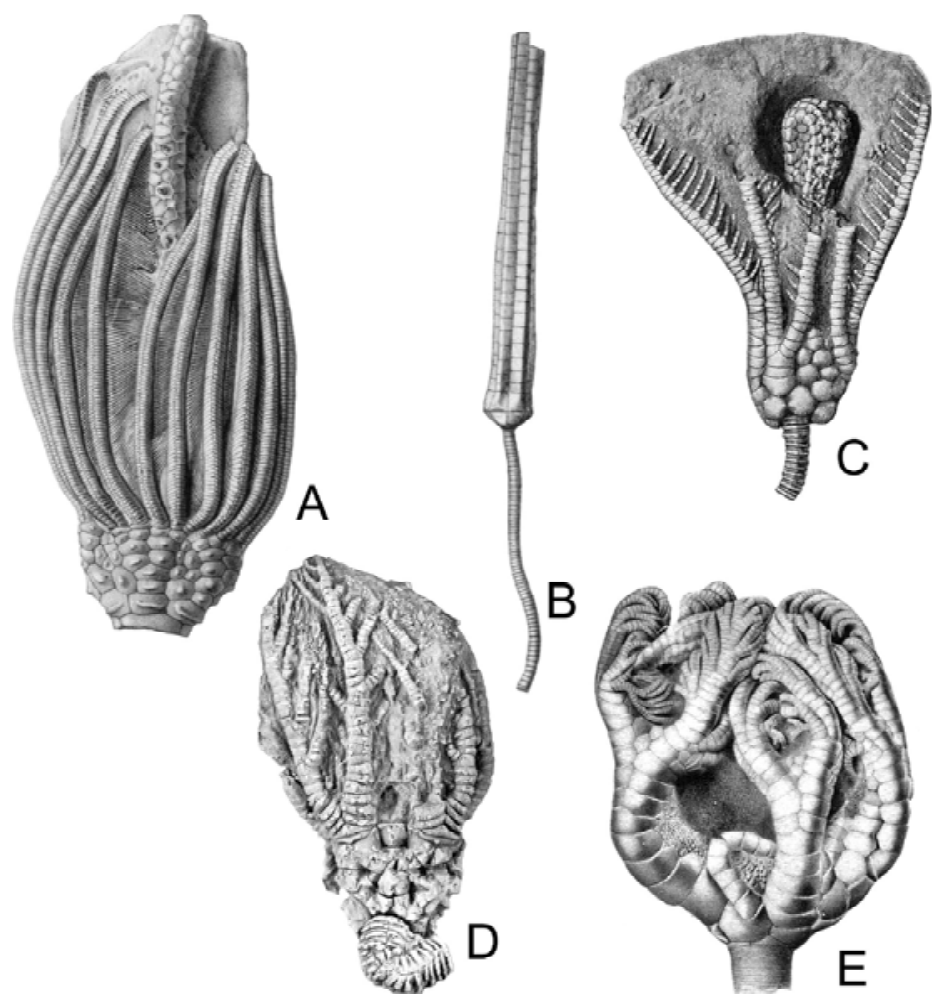

Figure 24. Representative examples of groups of crinoids from the Paleozoic.

(A) Abatocrinus grandis (Lyon), a camerate from the Osagean Edwardsville Formation, Crawfordsville, Indiana (Wachsmuth and Springer, 1897, pl. 27, fig. 1a); note dense, fine pinnules. (B) Synbathocrinus swallovi Hall, a disparid from the Meramecian Harrodsburg Limestone, Canton, Indiana (Wachsmuth and Springer, 1897, pl. 8, fig. 7). (C) Decadocrinus tumidulus (Miller and Gurley), an advanced cladid from the Osagean Edwardsville Formation, Indian Creek, Indiana (Springer, 1926, pl. 17, fig. 6); note large, coarse pinnules. (D) Barycrinus spectabilis Meek and Worthen, from the Meramecian St. Louis Limestone, Otter Creek, Illinois (Gahn and Kammer, 2002, fig. 1.15); note the ramulate arms. (E) Onychocrinus ulrichi Miller and Gurley, a flexible from the Osagean Edwardsville Formation, Indian Creek, Indiana (Springer, 1920, pl. 66, fig. 2); note ramulate arms (Kammer and Ausich, 2006, figure 2). 
The increase in diversity and overall number of crinoids during the Mississippian, which is referred to as the "Age of Crinoids," was ascribed by Kammer and Ausich (2006) not only to the success of crinoids surviving the Late Devonian extinction event but also to a favorable environment following that event that led to their radiation. According to Copper (1994, 2002), reefs providing rimmed shelves were decimated at the end of the Devonian, resulting in open carbonate ramp settings of the Mississippian. This allowed for a free flow of seawater from the open ocean, which in turn prevented the stagnation and elevated salinity that occurs behind reef structures (Figure 25).

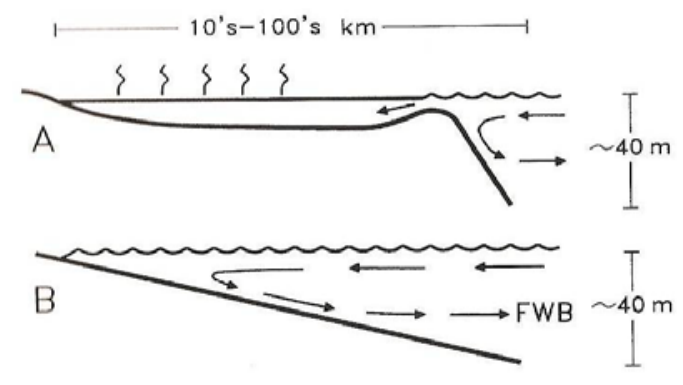

Figure 25. Demonstration of marine circulatory patterns with and without reefs. A. restricted circulation behind reef. B. open flow pattern without the reef. FWB: fair-weather wave base (Kammer and Ausich, 2006, figure 4).

Because crinoids are stenohaline, the Mississippian carbonate ramp environment would have been a more favorable one, in general, over the Devonian, allowing all crinoids to flourish under the improved conditions. It is also noted by Kammer and Ausich (2006) that the camerate crinoids did especially well. And while the proportion of the advanced cladid crinoids increased, the more primitive camerates returned to their pre-extinction diversity. Kammer and Ausich (2006) also noted that primitive cladids and disparids were more eurytopic and able to live in a broader range of habitats. 
Refuge areas, such as China, during the Late Devonian (Waters et al., 2003) may have provided the source of taxa for the re-expansion of crinoids after the Frasnian-Famennian extinction event (Simms, 1999; Kammer and Ausich, 2006). A large number of crinoids existed during the period from the Tournaisian to Serpukhovian (Mississippian) in North America and Western Europe. Many of the genera were widespread with approximately one half of those known in Western Europe also in North America. This implies a possible migration of crinoids from one continent to another. In the specific example of Gilmocrinus, it appears that the genus originated in North America, migrated to Europe, became extinct in North America, and then migrated back to North America. This demonstrates the potential of migration in both directions (Kammer et al., 2007).

A significant change in crinoid faunal composition occurred during the Meramecian and Chesterian stages (Lane, 1971; Bambach, 1977; Gahn, 2005; Kammer and Ausich, 2006). Following the dominance of camerates in diversity and number in the Silurian through the Middle Devonian, cladids gained ground after the Frasnian-Famennian extinction. During the Early Mississippian camerates regained some of that loss of dominance, and during the early Meramecian camerates co-dominated along with advanced cladids. Advanced cladid crinoids gradually increased in proportion over the other crinoids through the Mississippian and became dominant by the Serpukhovian (Chesterian) (Ausich, 1999; Kammer and Ausich, 2006); (Figure 23). That change reflected a period of "rapid faunal turnover during the middle Early Carboniferous," which was dominated by advanced cladids, and persisted through the end of the Paleozoic (Hess, et al., 1999). Ausich et al. (1994) and Kammer and 
Ausich (2003) also determined that this transition was not a single extinction event but was due to gradual background extinction.

Lane (1972) stated that the change in dominance between camerates and cladids occurred in the Middle Mississippian near the Osagean-Meramecian boundary. Dicyclic camerates became nearly extinct in the Upper Osagean and only six families of monocyclic camerates survived beyond that boundary. It is noted that at least one dicyclic camerate, Cribanocrinus persisted into the Meramecian. A specimen of this genus was also found at the Harris Stone quarry confirming the Meramecian age. This same genus was identified in the slightly younger upper Visean in Scotland (Kammer and Ausich, 2007a). The mid-point of the change of dominance from camerates to advanced cladids took place during deposition of the St. Louis Limestone, between the Salem and the Ste. Genevieve limestones. A decrease in all crinoid subclasses began in the Salem and was most exaggerated in the St. Louis. A rebound occurred in the Ste. Genevieve with the advanced cladids exceeding camerates in the number of genera (Figure 26). The overall number of crinoid genera decreased during the Meramecian. That decrease began in the Salem and the number of crinoid genera bottomed out in the St. Louis. 

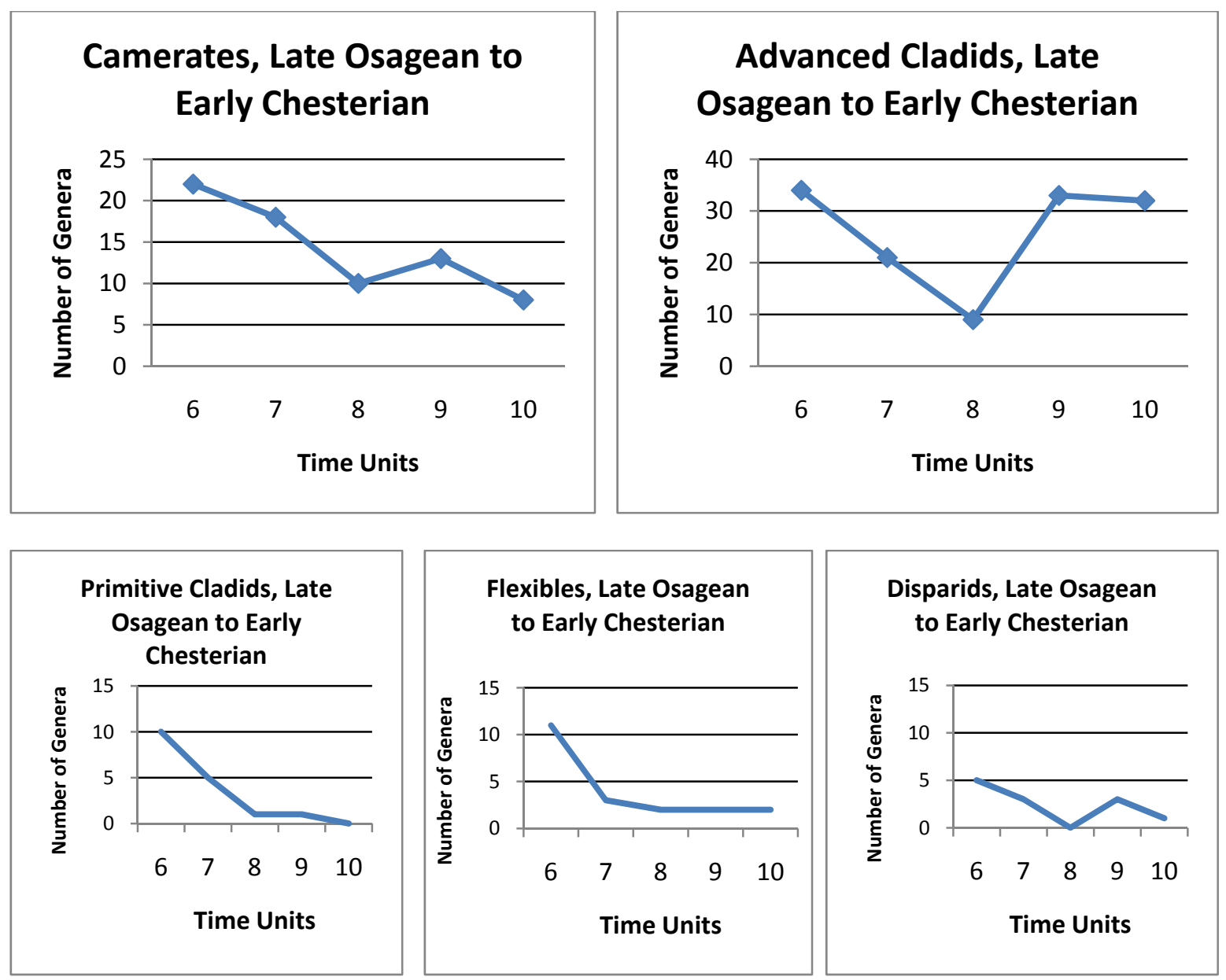

Figure 26. Change in number of crinoid genera from the late Osagean to the early Chesterian in North America. Time Units: 6, upper Keokuk, lower Warsaw; 7, upper Warsaw, Salem; 8, St. Louis; 9, Ste. Genevieve and early Chesterian; and 10, middle Chesterian. (Data for graphs from Kammer and Ausich, unpublished).

The rebound in the Ste. Genevieve, however, resulted in changes in the overall ratio of the subclasses. Advanced cladids returned from 34 genera in the lower Warsaw to 33 genera in the Ste. Genevieve; although they had dipped to 15 genera during the St. Louis (Figure 26). The distribution of advanced cladids appears to be inconsistent between sources of data, but has an explanation. The time unit Seven designated by Kammer and Ausich (unpublished 
data) includes the upper Warsaw with the Salem Limestone. Within that time unit, sixteen advanced cladids are listed (Table 4). On close inspection of the data provided by Webster (2003), it is noted that nine of those sixteen advanced cladids occur in the Warsaw and not the Salem. The remaining seven advanced cladids occur in the Warsaw and the Chesterian but are not in the Salem Limestone. It is assumed that those seven would have been Lazarus taxa (taxa that have skipped formations). The limited number of specimens from that age could be explained by lack of preserved specimens in the explored areas or destruction of that stratigraphic layer by erosion. Although it appears that no advanced cladids were present in the Salem Limestone (Table 5), they are more likely missing as a result of taphonomic processes leading to their disappearance.

Camerates did not recover to the extent of the advanced cladids, having 24 genera in the lower Warsaw, 9 in the St. Louis and 13 genera in the Ste. Genevieve. [Although the specifics of the distribution of crinoids were altered as a result of this study, the trends remained the same.] A trend appears in the distribution of camerate genera. Batocrinidae is concentrated in the Keokuk, Warsaw and Salem. Dichocrinidae occurs from the Keokuk through the Chesterian. Acrocrinidae appears before the Chesterian. Those kinds of groupings do not appear in the seriation of advanced cladids (Table 5). Primitive cladids locally disappeared altogether after the St. Louis, whereas flexibles and disparids maintained a low level of persistence (Tables 5 and 6; Figure 26). 


\begin{tabular}{|l|l|l|l|l|l|l|l|}
\cline { 2 - 7 } \multicolumn{1}{c|}{} & $\begin{array}{r}\text { Time } \\
\text { Unit }\end{array}$ & $\mathbf{6}$ & $\mathbf{7}$ & $\begin{array}{l}\mathbf{8} \\
\text { Previous }\end{array}$ & $\begin{array}{l}\mathbf{8} \\
\text { Current }\end{array}$ & $\mathbf{9}$ & $\mathbf{1 0}$ \\
\hline Subclass & & & & & & & \\
\hline Camerates & & 24 & 19 & 11 & 9 & 13 & $\mathbf{8}$ \\
\hline Advanced Cladids & 34 & 21 & 15 & 9 & 33 & 32 \\
\hline Primitive Cladids & & 10 & 5 & 2 & 1 & 0 & 0 \\
\hline Flexibles & 11 & 3 & 2 & 2 & 2 & 2 \\
\hline Disparids & & $\mathbf{3}$ & $\mathbf{3}$ & $\mathbf{2}$ & $\mathbf{0}$ & $\mathbf{3}$ & $\mathbf{1}$ \\
\hline
\end{tabular}

Table 4. Distribution of crinoid genera over Mississippian formations. Time Units: 6, upper

Keokuk, lower Warsaw; 7, upper Warsaw, Salem; 8, St. Louis (Note two entries; previous and current); 9, Ste. Genevieve and early Chesterian; and 10, middle Chesterian.

(Adapted from Kammer and Ausich, unpublished). 


\begin{tabular}{|c|c|c|c|c|c|c|}
\hline Genera & 6 & 7 & 8 & 9 & 10 & Family \\
\hline \multicolumn{7}{|l|}{ Camerates } \\
\hline Abatocrinus & $\mathrm{X}$ & & & & & Batocrinidae \\
\hline Alloprosallocrinus & $\mathrm{X}$ & & & & & Batocrinidae \\
\hline Eucladocrinus & $\mathbf{x}$ & & & & & Platycrinidae \\
\hline Eutrochocrinus & $\mathrm{X}$ & & & & & Batocrinidae \\
\hline Uperocrinus & $\mathbf{x}$ & & & & & Batocrinidae \\
\hline Paradichocrinus & $\mathbf{X}$ & & & & & Dichocrinidae \\
\hline Actinocrinites & $\mathbf{X}$ & $\mathrm{X}$ & & & & Actinocrinidae \\
\hline Agaricocrinus & $\mathbf{x}$ & $\mathrm{X}$ & & & & Coelocrinidae \\
\hline Dizygocrinus & $\mathbf{X}$ & $\mathrm{X}$ & & & & Batocrinidae \\
\hline Dorycrinus & $\mathrm{X}$ & $\mathbf{X}$ & & & & Coelocrinidae \\
\hline Eretmocrinus & $\mathbf{X}$ & $\mathbf{X}$ & & & & Batocrinidae \\
\hline Gilbertsocrinus & $\mathrm{X}$ & $\mathbf{X}$ & & & & Rhodocrinidae \\
\hline Macrocrinus & $\mathbf{x}$ & $\mathrm{X}$ & & & & Batocrinidae \\
\hline Aorocrinus & $\mathrm{X}$ & $\mathrm{X}$ & & & & Coelocrinidae \\
\hline Azygocrinus & $x$ & $\mathrm{X}$ & & & & Batocrinidae \\
\hline Batocrinus & $\mathrm{X}$ & $\mathrm{X}$ & & & & Batocrinidae \\
\hline Cribanocrinus & $\mathrm{X}$ & & $\mathrm{X}$ & & & Rhodocrinidae \\
\hline Platycrinites & $\mathrm{X}$ & $\mathbf{X}$ & $\mathrm{X}$ & $\mathrm{X}$ & & Platycrinidae \\
\hline Camptocrinus & $\mathrm{X}$ & $\mathrm{X}$ & $\mathrm{X}$ & $\mathrm{X}$ & $\mathbf{x}$ & Dichocrinidae \\
\hline Hyrtanecrinus & $\mathrm{x}$ & $\mathrm{X}$ & $\mathrm{X}$ & $\mathrm{X}$ & $x$ & Dichocrinidae \\
\hline Dichocrinus & $\mathrm{X}$ & $\mathrm{X}$ & $\mathrm{X}$ & $\mathrm{X}$ & $\mathrm{X}$ & Dichocrinidae \\
\hline Strimplecrinus & $\mathbf{x}$ & $\mathbf{X}$ & $\mathbf{L}$ & $\mathbf{L}$ & $\mathbf{x}$ & Dichocrinidae \\
\hline Talarocrinus & & $\mathrm{X}$ & $\mathrm{X}$ & $\mathrm{X}$ & $\mathrm{X}$ & Dichocrinidae \\
\hline Acrocrinus & & & & $\mathrm{X}$ & $\mathbf{x}$ & Acrocrinidae \\
\hline Pterotocrinus & & & & $\mathrm{X}$ & $\mathbf{x}$ & Dichocrinidae \\
\hline Springeracrocrinus & & & & $\mathrm{X}$ & $\mathrm{X}$ & Acrocrinidae \\
\hline Rhodocrinites & & $\mathrm{X}$ & & & & Rhodocrinidae \\
\hline Globocrinus & & $\mathrm{X}$ & $\mathbf{L}$ & $\mathrm{X}$ & & Batocrinidae \\
\hline Amphoracrocrinus & & & & $\mathrm{X}$ & & Acrocrinidae \\
\hline Paratalarocrinus & & & & $\mathrm{X}$ & & Dichocrinidae \\
\hline TOTAL & 22 & 18 & 6 & 11 & 8 & \\
\hline
\end{tabular}

Table 5. Seriation of camerate and advanced cladid genera through the Osagean,

Meramecian and Chesterian. A trend appears in the distribution of camerate genera.

Batocrinidae is concentrated in the Keokuk, Warsaw and Salem. Dichocrinidae

occurs from the Keokuk through the Chesterian. Acrocrinidae appears in the

Chesterian. Such regular groupings do not appear in the seriation of advanced cladids.

Time units: 6, upper Keokuk, lower Warsaw; 7, upper Warsaw, Salem; 8, St. Louis; 9,

Ste. Genevieve and early Chesterian; and 10, middle Chesterian. $\underline{\mathbf{L}}=$ Larazus gap.

(Kammer and Ausich, unpublished). 


\begin{tabular}{|c|c|c|c|c|c|c|}
\hline Adv. Cladids Genera & 6 & 7 & 8 & 9 & 10 & Family \\
\hline Bollandocrinus & $\mathrm{X}$ & & & & & Scytalocrinidae \\
\hline Corythocrinus & $\mathbf{X}$ & & & & & Corythrocrinidae \\
\hline Cosmetocrinus & $\mathbf{X}$ & & & & & Aphelecrinidae \\
\hline Cromyocrinus & $\mathbf{X}$ & & & & & Cromyocrinidae \\
\hline Decadocrinus & $\mathbf{X}$ & & & & & Decadocrinidae \\
\hline Cydrocrinus & $\mathbf{X}$ & & & & & Rhenocrinidae \\
\hline Graphiocrinus & $\mathbf{X}$ & & & & & Graphiocrinidae \\
\hline Histocrinus & $\mathrm{X}$ & & & & & Scytalocrinidae \\
\hline Holocrinus & $\mathrm{X}$ & & & & & Graphiocrinidae \\
\hline Ophiurocrinus & $\mathrm{x}$ & & & & & Scytalocrinidae \\
\hline Pelecocrinus & $\mathrm{X}$ & & & & & Pelecocrinidae \\
\hline Adinocrinus & $\mathrm{X}$ & & & & & Adinocrinidae \\
\hline Springericrinus & $\mathrm{X}$ & & & & & Poteriocrinidae \\
\hline Worthenocrinus & $\mathbf{X}$ & & & & & Zeacrinidae \\
\hline Aulocrinus & $\mathbf{X}$ & $\mathbf{X}$ & & & & Decadocrinidae \\
\hline Eratocrinus & $\mathrm{X}$ & $\mathbf{X}$ & & & & Zeacrinidae \\
\hline Hylodecrinus & $\mathrm{X}$ & $\mathrm{x}$ & & & & Staphylocrinidae \\
\hline Hypselocrinus & $\mathbf{x}$ & $\mathbf{X}$ & & & & Scytalocrinidae \\
\hline Lebetocrinus & $\mathrm{x}$ & $\mathrm{x}$ & & & & Bursacrinidae \\
\hline Lekocrinus & $\mathrm{X}$ & $\mathrm{X}$ & & & & Zeacrinidae \\
\hline Parascytalocrinus & $\mathrm{x}$ & $\mathrm{x}$ & & & & Scytalocrinidae \\
\hline Ulrichicrinus & $\mathrm{X}$ & $\mathrm{X}$ & & & & Blothrocrinidae \\
\hline Sarocrinus & $\mathrm{X}$ & $\mathrm{X}$ & & & & Zeacrinidae \\
\hline Dinotocrinus & $\mathrm{x}$ & $\mathrm{L}$ & $\mathrm{x}$ & $\mathrm{x}$ & & Staphylocrinidae \\
\hline Abrotocrinus & $\mathbf{x}$ & $\mathrm{x}$ & & $\mathbf{x}$ & & Staphylocrinidae \\
\hline Armenocrinus & $\mathrm{x}$ & $\mathrm{L}$ & $\mathbf{X}$ & $\mathrm{X}$ & & Ampelocrinidae \\
\hline Poteriocrinites & $\mathbf{X}$ & $\mathrm{L}$ & $\mathrm{L}$ & $\mathrm{x}$ & & Poteriocrinidae \\
\hline Scytalocrinus & $\mathrm{x}$ & $\mathbf{X}$ & $\mathrm{L}$ & $\mathrm{x}$ & & Scytalocrinidae \\
\hline Culmicrinus & $\mathrm{x}$ & $\mathrm{x}$ & $\bar{x}$ & & $\mathbf{X}$ & Blothrocrinidae \\
\hline Lanecrinus & $\mathrm{X}$ & $\mathrm{X}$ & $\mathrm{L}$ & $\mathbf{x}$ & $\mathrm{X}$ & Decadocrinidae \\
\hline Pachylocrinus & $\mathrm{x}$ & $\mathrm{x}$ & $\bar{x}$ & $\mathrm{x}$ & $\mathrm{X}$ & Pachylocrinidae \\
\hline Linocrinus & & $\mathrm{X}$ & $\mathrm{L}$ & $\mathrm{X}$ & $\mathrm{X}$ & Zeacrinidae \\
\hline Zeacrinites & & $x$ & $L$ & $x$ & $x$ & Zeacrinidae \\
\hline Aphelecrinus & & & $\mathbf{X}$ & $\mathrm{x}$ & $\mathrm{X}$ & Aphelecrinidae \\
\hline Cymbiocrinus & & & $\mathrm{x}$ & $\mathrm{x}$ & $x$ & Cymbiocrinidae \\
\hline Pentaramicrinus & & & & $\mathbf{X}$ & $\mathrm{X}$ & Planocrinidae \\
\hline Phacelocrinus & & & $\mathbf{x}$ & $\mathbf{x}$ & $\mathrm{X}$ & Scytalocrinidae \\
\hline Aenigmocrinus & & & & $\mathrm{x}$ & $\mathrm{x}$ & Cymbiocrinidae \\
\hline Agassizocrinus & & & & $\mathrm{X}$ & $\mathrm{X}$ & Agassizocrinidae \\
\hline Ampelocrinus & & & & $\mathrm{X}$ & $\mathrm{X}$ & Ampelocrinidae \\
\hline Anartiocrinus & & & & $\mathrm{x}$ & $\mathrm{x}$ & Agassizocrinidae \\
\hline Cryphiocrinus & & & & $\mathrm{x}$ & $\mathrm{X}$ & Planocrinidae \\
\hline Dasciocrinus & & & & $\mathrm{x}$ & $\mathrm{x}$ & Pirasocrinidae \\
\hline Eupachycrinus & & & & $\mathrm{x}$ & $\mathrm{x}$ & Eupachycrinidae \\
\hline Exochocrinus & & & & $\mathrm{x}$ & $x$ & Staphylocrinidae \\
\hline Fifeocrinus & & & & $\mathrm{x}$ & $\mathrm{X}$ & Blothrocrinidae \\
\hline Phanocrinus & & & & $\mathrm{x}$ & $\mathrm{X}$ & Planocrinidae \\
\hline Ramulocrinus & & & & $\mathrm{x}$ & $\mathrm{x}$ & Decadocrinidae \\
\hline Rhopocrinus & & & & $\mathrm{X}$ & $\mathrm{X}$ & Stellarocrinidae \\
\hline Staphylocrinus & & & & $\mathrm{x}$ & $\mathrm{x}$ & Staphylocrinidae \\
\hline Tholocrinus & & & & $\mathrm{X}$ & $\mathrm{X}$ & Zeacrinidae \\
\hline Harmostocrinus & & & & $\mathrm{x}$ & & Staphylocrinidae \\
\hline Intermediacrinus & & & & $\mathrm{X}$ & & Eupachycrinidae \\
\hline Paianocrinus & & & & $\hat{x}$ & & Laudonocrinidae \\
\hline Rhabdocrinus & & & & $\mathrm{x}$ & & Poteriocrinidae \\
\hline Snowycrinus & & & & $\mathrm{X}$ & & \\
\hline Alcimocrinus & & & & & $\mathrm{X}$ & Zeacrinidae \\
\hline Bicidiocrinus & & & & & $\mathrm{x}$ & Zeacrinidae \\
\hline Goleocrinus & & & & & $\mathrm{x}$ & Cromyocrinidae \\
\hline Mantikosocrinus & & & & & $\mathrm{x}$ & Cromyocrinidae \\
\hline Pulaskicrinus & & & & & $\mathrm{X}$ & Scytalocrinidae \\
\hline Scammatocrinus & & & & & $\mathrm{x}$ & Blothrocrinidae \\
\hline Telikosocrinus & & & & & $\mathrm{x}$ & Ulocrinidae \\
\hline Tyrieocrinus & & & & & $\hat{x}$ & Ulocrinidae \\
\hline Wetherbyocrinus & & & & & $\mathrm{x}$ & Scytalocrinidae \\
\hline TOTAL & 31 & 16 & 7 & 32 & 32 & \\
\hline
\end{tabular}

(Table 5 continued with advanced cladids only) 


\section{Crinoid Morphology}

Crinoids developed morphological changes during the Paleozoic that may have contributed to their success as a group as well as to the transitions that occurred as the advanced cladids became dominant over the camerates. The more significant of these changes include a decrease in size and complexity of the calyx, development of muscular arms in addition to mutable collagen, a compromise in feeding filter density, and strategies to survive predation. Some of these occurred prior to the Meramecian, and may have placed crinoids in a position to survive the Devonian extinction event and flourish afterward. In addition, those changes provided the base line in crinoid morphology leading into the Meramecian. Those particular modifications in morphology equipped crinoids that did well with characteristics that were beneficial to their survival in a changing environment. Some recurred as convergent and parallel developments (Ausich, 1988) setting the stage for variability that fostered survival in different environments. This demonstrates the built-in adaptability of crinoids, which was another factor that allowed some to thrive. Those crinoid taxa that either did not change or adapted in thewrong direction were destined to fail.

Ausich (1988) described eleven basic crinoid calyx designs. These generally related to the shape, size, number of plates, number of arms and type of sutures between plates. The different designs allowed a means of distinguishing taxonomic differences, but more importantly reflect adaptation by evolutionary means to better suit an environmental niche. In a series of three papers, Kammer and Ausich (1992, 1993, and 1994) described a trend in the advanced cladids toward calyx size reduction. This occurred by changes in the basal and infrabasal plates relative to the radial plates. They also divided those changes into primitive, 
intermediate and advanced designs which reflect changes in size and shape of advanced cladids calyces through time. That same change of calyx size reduction appears to be consistent with the other sub-classes of crinoids (Ausich, 1988; Kammer and Ausich, 1992; and Ausich, 1996). Advanced cladids did not exhibit a significant trend in design change from the Osagean through the Chesterian (figure 27). Those calyceal modifications occurred just prior to this time from the Lower Devonian through the Lower Mississippian (Kammer and Ausich, 1992).

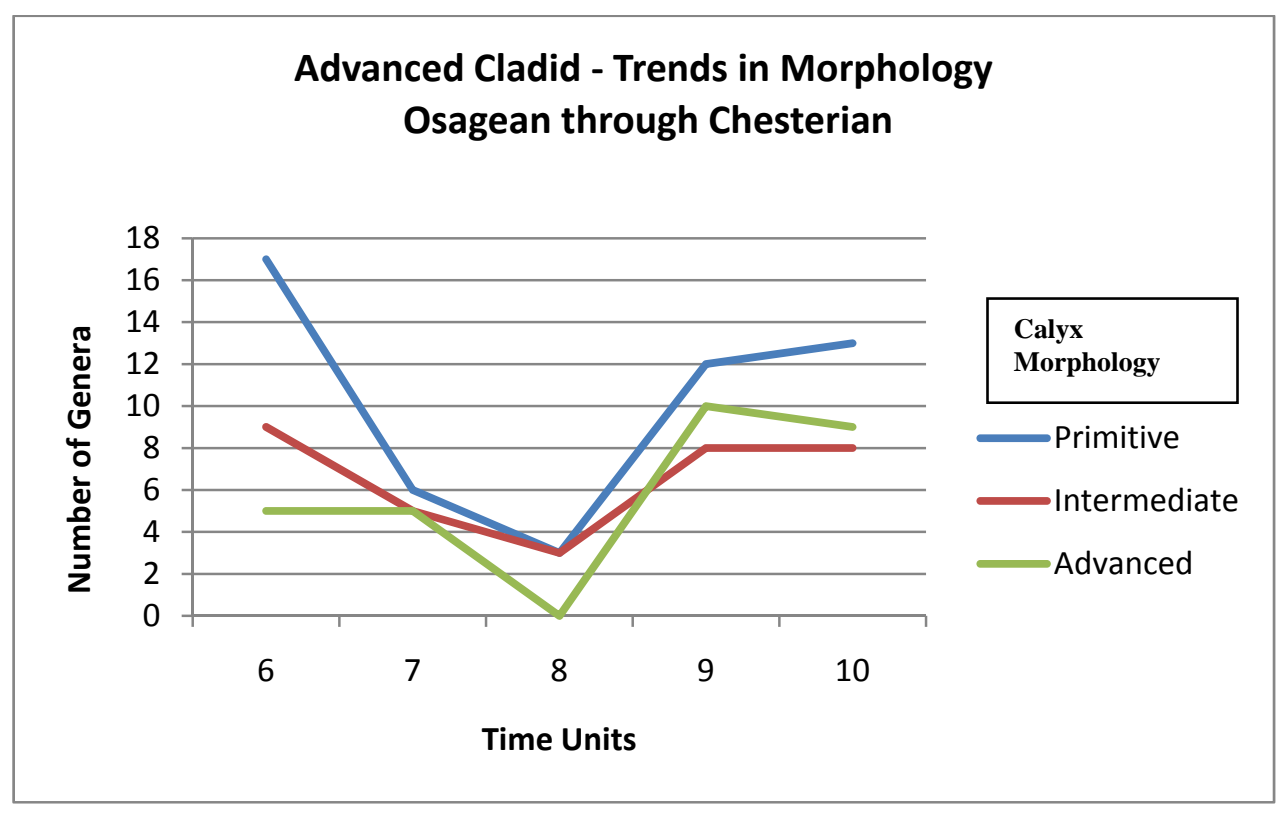

Figure 27. Trends in calyx morphology of advanced cladids from the Osagean through the Chesterian by genera per time unit. Time units: 6, upper Keokuk, lower Warsaw; 7, upper Warsaw, Salem; 8, St. Louis; 9, Ste. Genevieve and early Chesterian; and 10, middle Chesterian. (Data for graphs derived from Kammer and Ausich, unpublished; Kammer and Ausich, 1992, 1993, 1994).

In contrast to the advanced cladids, a trend in the change of camerate calyx morphology is present from the Osagean through the Chesterian. Earlier camerates, through the early 
Meramecian, mostly had larger calyces and a large number of interradial and intrabrachial plates along with fixed brachials, which made for a complex calyx. Camerate calyces later became smaller and contained fewer plates, rarely including interradials, intrabrachials, or fixed arm plates; these camerates could be said to have simple calyces (Figure 28). As seen in table 4 , the crinoids with complex calyces, represented by the Batocrinidae, were prevalent before the St. Louis in late Osagean and early Meramecian, but the simple calyces were prevalent coming out of the St. Louis (Figure 29). The ratio of the complex calyx to simple calyx camerates reversed from 15:4 species in the Salem Limestone to 0:9 species in the St. Louis (Table 6).

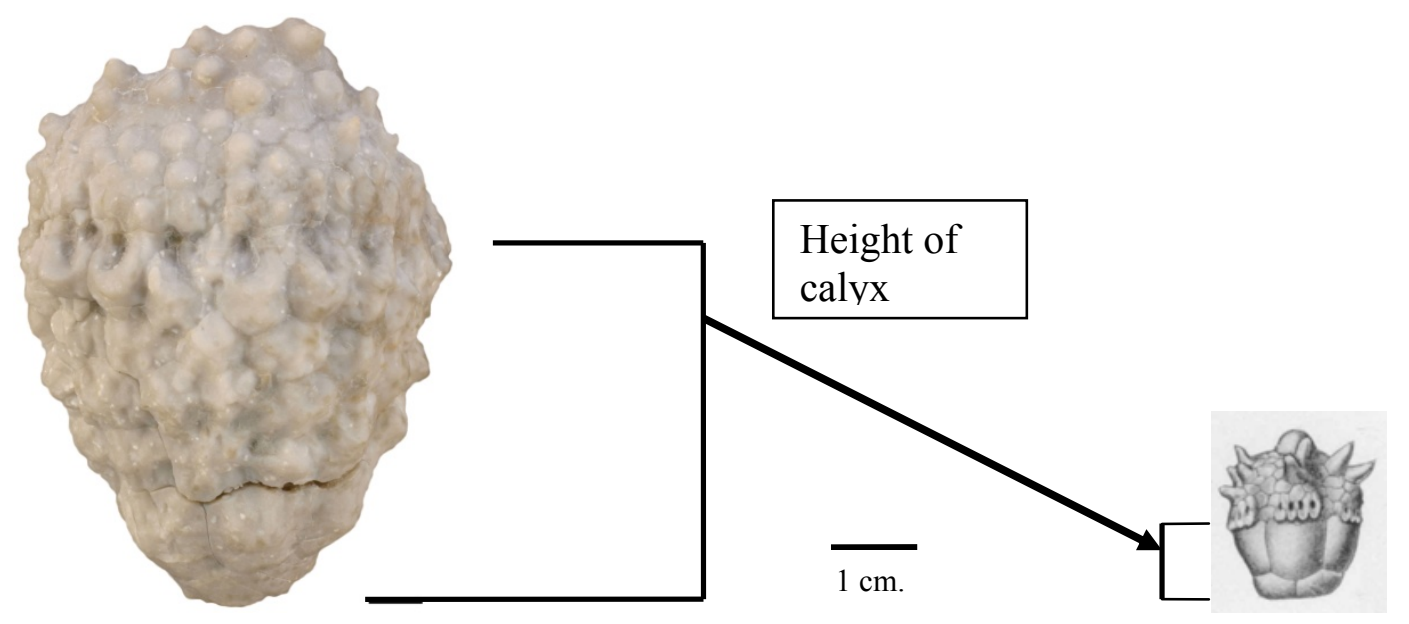

Figure 28. Comparison of complex to simple calyces. Left, a complex calyx crinoid, Cactocrinus, Osagean of New Mexico. Right, a simple calyx crinoid, Talarocrinus cornigerus, Meramecian-Chesterian of Alabama. Note the calyx of Talarocrinus the calyx corresponds to the much larger Cactocrinus, which includes fixed brachials. Also note the dramatic decrease in number of plates in the calyx of the Talarocrinus. Scale bar $=1$ centimeter. (Cactocrinus provided by Elizabeth Rhenberg, Talarocrinus from Wachsmuth and Springer, 1897, Plate 78, figure 7a). 


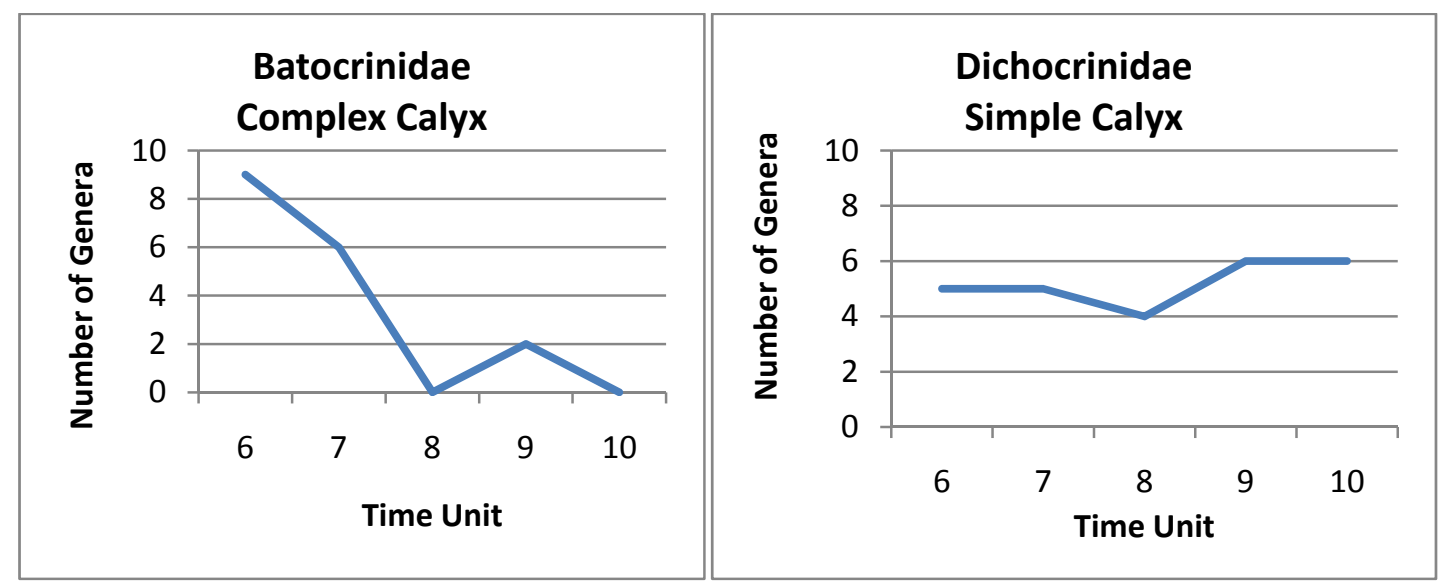

Figure 29. Examples of change in number of genera within camerate families through the Middle Paleozoic. Batocrinidae with a complex calyx decreases in diversity. Dichocrinidae with a simple calyx increases in diversity. Time Units: 6, upper Keokuk, lower Warsaw; 7, upper Warsaw, Salem; 8, St. Louis; 9, Ste. Genevieve and early Chesterian; and 10, middle Chesterian. (Data for graphs derived from Kammer and Ausich, unpublished). 


\begin{tabular}{|l|c|c|c|}
\hline $\begin{array}{l}\text { CRINOID } \\
\text { CLASS }\end{array}$ & $\begin{array}{c}\text { Salem } \\
\text { Limestone }\end{array}$ & $\frac{\text { St. Louis }}{\text { Limestone }}$ & $\frac{\text { Ste. Genevieve }}{\text { Limestone }}$ \\
\hline $\begin{array}{l}\text { Camerates: } \\
\text { Complex Calyx }\end{array}$ & 15 & 0 & 1 \\
\hline $\begin{array}{l}\text { Camerates: } \\
\text { Simple Calyx }\end{array}$ & 4 & 9 & 5 \\
\hline Disparids & 2 & 0 & 0 \\
\hline $\begin{array}{l}\text { Primitive } \\
\text { Cladids }\end{array}$ & 4 & 1 & 0 \\
\hline $\begin{array}{l}\text { Advanced } \\
\text { Cladids }\end{array}$ & 0 & 9 & 26 \\
\hline Flexibles & 2 & 2 & 3 \\
\hline
\end{tabular}

Table 6. Distribution of crinoid species between the Salem, St. Louis and Ste. Genevieve limestones. The numbers in the St. Louis column are based on this study. Camerates with complex calyces have larger size and a greater number of plates. Camerates with a simple calyx have smaller size and a lesser number of plates (Figure 28). Note that the number of species on this chart does not reflect number of genera that may occur in other tables and figures; this table shows only those identified in the Salem, St. Louis and Ste. Genevieve limestones by Webster (2003) and this study.

Changes in crinoid arm morphology demonstrate both adaptation and convergence over time. Earlier camerates developed a very dense filter from pinnules that was intensified by biserial brachials and increased number of arms. This adaptation was beneficial in low turbidity environments as the animal was able to filter out large amounts of organic food particles. As camerates evolved through the Ordovician, Silurian and Devonian periods, the development of a denser filter would have been advantageous. However, that same character became a disadvantage in the more siliciclastic-laden Osagean seas (Khetani and Read, 
2002), serving to facilitate clogging (Lane, 1972; Kammer, 1985; Kammer and Ausich, 1987; Baumiller, 1993).

A compromise in the number of pinnules and arms was made by the cladids. The primitive cladids had no pinnules; the advanced cladids developed pinnules that were less dense on typically uniserial brachials. Compared to the more dense distribution of pinnules on biserial brachials of camerates, a compromise in filter density was achieved. This alone would have provided some advantage for capturing more food with less clogging in clastic turbidity (Kammer, 1985; Kammer and Ausich, 1987; Baumiller, 1993). However, advanced cladids evolved the further benefit of muscular arms in addition to the use of mutable collagen for positioning and movement. This permitted them to mitigate clogging by flicking off the unwanted debris (Kammer et al., 1998; Baumiller, 2008). Adaptation of filter density in the arms was primarily related to feeding. The compromise of a less dense filter and the acquisition of the ability to clear unwanted siliciclastic sediment provided an advantage for advanced cladids over camerates in less than ideal environments for crinoids in general.

Associated changes in filter density included a variation in ambulacral groove width. Crinoids, such as camerates with small-particle capture, had more narrow grooves. Those such as primitive cladids, flexibles and disparids with larger-particle capture had wider grooves (Ausich, 1980). Graduated groove width allowed accommodation for intermediatesize particles in advanced cladids (Kammer and Ausich, 1987). The further adaptation of a more extensive sensory system that may have enabled better food detection ability came about in the advanced cladids. Lane (1972) compared the voluminous porous anal sac of 
potericrinitids to the solid, impervious tegmen of camerates and suggested that "poteriocrinitids may have a more extensive sensory system, enabling them to assess water quality and presence of food."

These morphological changes for feeding were adaptive to the differences between two variables: the sedimentological setting (carbonate or siliciclastic) and current energy. According to Kammer et al. (1998) crinoid arm characters were associated with the particular environment with which they were compatible. Higher filter density and smaller ambulacral grooves were found in higher energy environments. Lower filter density and larger ambulacral grooves were found in lower energy environments. Carbonate environments with clearer water supported crinoids with denser arm structures better than in siliciclastic environments.

Crinoids were also compromised in their attributes to allow for more flexibility for survival. Some were able to live in a broader spectrum of available settings and were considered as generalists, also referred to as eurytopic. On the other hand, some crinoids were narrow in their tolerance of variability in the environment and were considered specialists, also referred to as stenotopic. Within these two concepts lay potential advantage and disadvantage. In the short run, being a generalist had the advantage of being able to live in multiple settings. In the long run, specialists had higher rates of speciation and could adapt to changing conditions more readily. This led to higher richness in specialists over the long term (Eldredge, 1979; Kammer et al., 1998). 


\section{Adaptation}

Several hypothetical factors have been proposed that may have influenced the transition in crinoid macroevolutionary patterns during the Middle to Late Mississippian. Ruling out a mass extinction event, Ausich, et al. (1994) suggested that these factors may have included sea level changes, habitat loss, autecology or competition as processes of change. Kammer and Ausich (2006) hypothesized changes in sea-level and salinity, in addition to siliciclastic influx, as potential environmental factors. Some consideration has been given to differences in suspension feeding niches as a factor. Ausich (1980) provided evidence of morphological adaptation that allowed for tiering and a resultant spectrum of feeding niches within the various environments where crinoids lived.

Siliciclastic influx in the Illinois Basin was intermittent during the Mississippian. During the Early Mississippian clastics from the Acadian orogen crossed the Cincinnati Arch and formed the Borden Formation within the Illinois Basin. That influx ended at the OsageanMeramecian boundary and a period of carbonate formation lasted from the Warsaw Formation through the Ste. Genevieve Limestone (Kammer and Cox, 1985; Carney and Smosna, 1989; Matchen and Kammer, 1994; Khetani and Read, 2002). Under conditions of siliciclastic influx, muscular arm articulations gave advanced cladids the ability to move their arms in a way that would clear there feeding mechanisms of unwanted sediment (Kammer and Ausich, 1987; Kammer et al., 1998). Muscular articulations evolved during the Early Devonian in advanced cladids with pinnulate arms (Ausich and Baumiller, 1993), well before the Meramecian. Having the ability to deal with that influx in combination with other variables may have given a differential advantage to the advanced cladids at a later stage. 
That was shown by Kammer and Ausich (2006) by the radiation of advanced cladids during the clastic influx of the Late Mississippian.

Predation and the development of defenses to compensate for predation may have played a role in the differential survival of some crinoids over others. The changes in morphology that would have allowed for survival in the face of predation evolved during the Devonian (Lane, 1984), and the advanced cladids were ahead of the camerates in that regard (Lane, 1984; Waters et al., 2001). Diversification in the advanced cladids coincided with the radiation of predatory fish and ammonoid cephalopods (Signor and Brett, 1984; Lane, 1984; Brett and Walker, 2002) (Figure 29). Given Van Valen's (1973) and Vermeij’s (1977) concepts of escalating adaptations between predator and prey, continued adaptation would be expected. As a result, ongoing changes must have occurred allowing crinoids to survive. According to Lane (1984), potential morphological changes that would increase survivability included spinosity, thickened calyx plates, longer anal sac, regeneration of the anal sac, and relocation of gonads. Signor and Brett (1984) as well as Baumiller and Gahn (2004) and Gahn and Baumiller (2005) added the ability to regenerate arms to this list. 


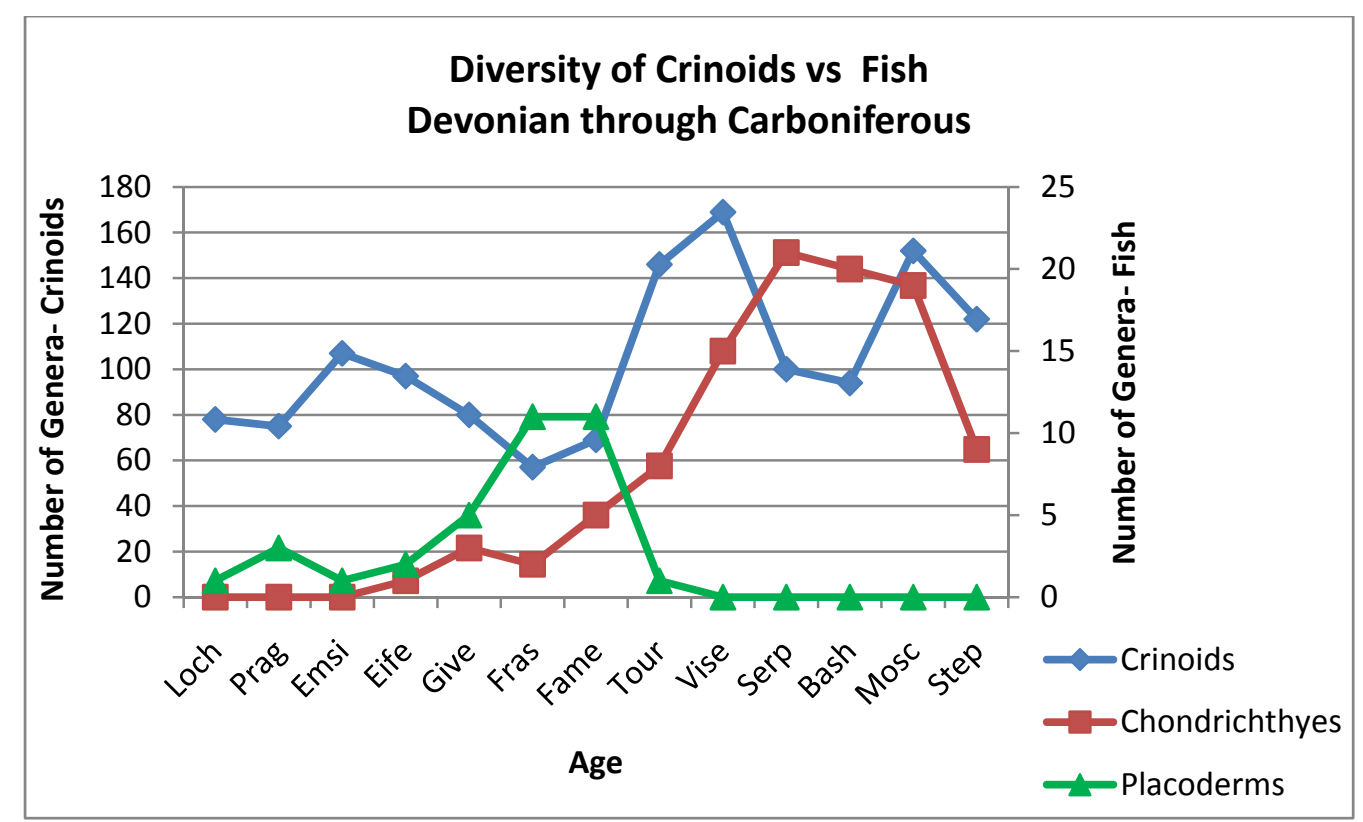

Figure 30. Distribution of number of genera of crinoids and predatory fish through the Middle Paleozoic. Note opposite direction of trends for fish and crinoids. (Graph adapted from Bambach, 2002, Minimum standing diversity; Kammer and Ausich, 2006).

During the Middle Devonian radiation of shell-crushing marine predators occurred. These included placoderms, osteichythes, and chondrichthyan fish; phyllocarid and eumalacostracan arthropods; and ammonoid cephalopods. Placoderms became extinct at the end of the Devonian (Maisey, 1996; Brett and Walker, 2002). Arthropods and osteichythes of that time were unlikely to have been much of a threat to crinoids. They were small and did not have the shell crushing ability that they developed later (Signor and Brett, 1984;

Kammer, personal communication). Through the Paleozoic, the lowest number of genera of crinoids occurred at the peaks in the number of genera of predatory fish (Figure 30). Chondrichthyes dramatically increased from 10 families in the Late Devonian to 24 families in the Late Carboniferous (Maisey, 1996). Given their numbers and efficiency at predation, chondrichthyes were likely to have had, by far, the greatest impact on crinoid diversity. 
However, when the camerates and advanced cladids are evaluated separately, a different relationship emerges. Camerate numbers decline steadily after the rapid increase in the number of chondrichthyes (Figure 31). The association of an increasing numbers of predators in the face of dwindling numbers of its prey implies a cause and effect.

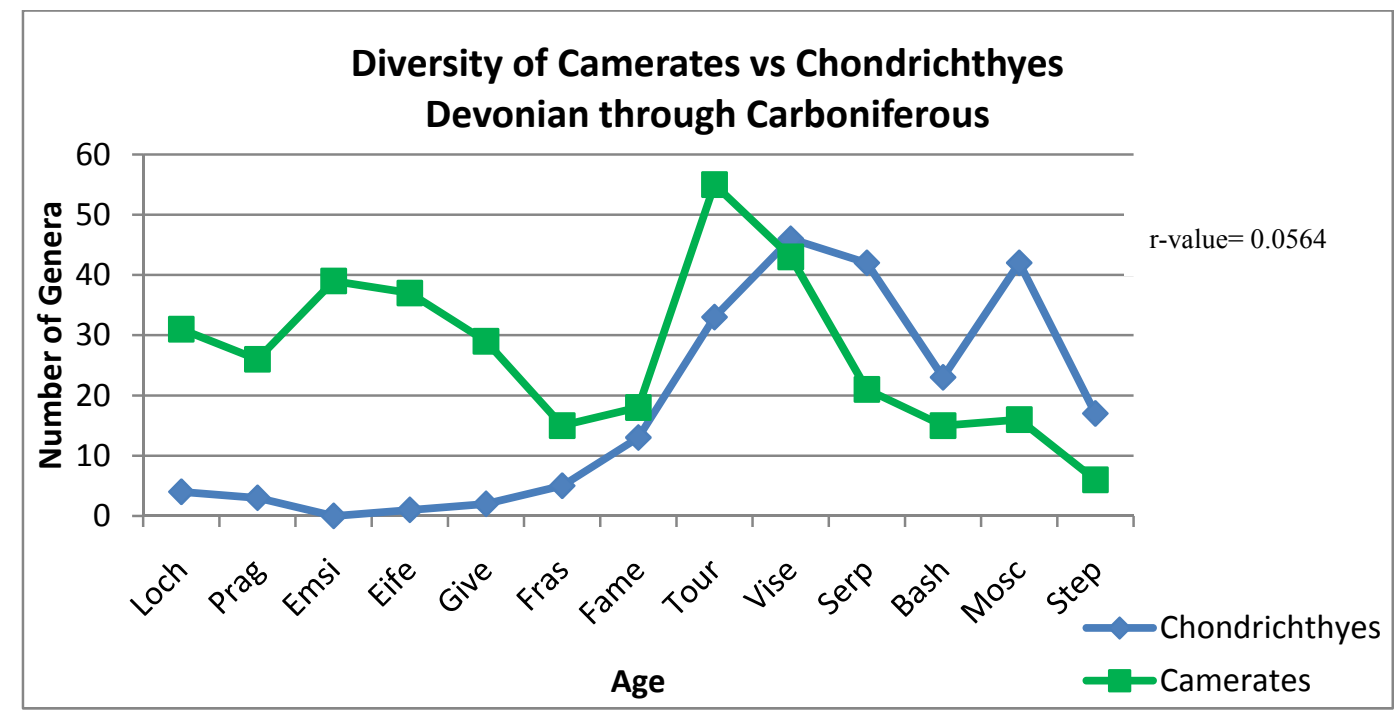

Figure 31. Diversity of camerate versus chondrichthyes from the Devonian through the Carboniferous. Camerates are decreasing while at the same time chrondrichthyes are increasing. The parallel increase of both crinoids and chondrichthyes in the Famennian reflects the changeover in dominance of predators from placoderms to chondrichthyes seen in Figure 30 (Data from Sepkowski, 2002, total diversity; Kammer and Ausich, 2006).

The same comparison with the number of genera of advanced cladids and chondrichthyes does not have the same decline (Figure 32). Advanced cladids and chondrichthyes follow the same pattern of increase and decrease through time. This implies a contrary effect of the chondrichthyes on advanced cladids compared to camerates. In other words, camerates appear to have been negatively impacted by chondrichthyes while advanced cladids were not. 
Both camerates and advanced cladids dip at the Mississippian-Pennsylvanian (Bashkirian) boundary as sea level fell, (Ross and Ross, 1988) and fewer marine rocks were preserved.

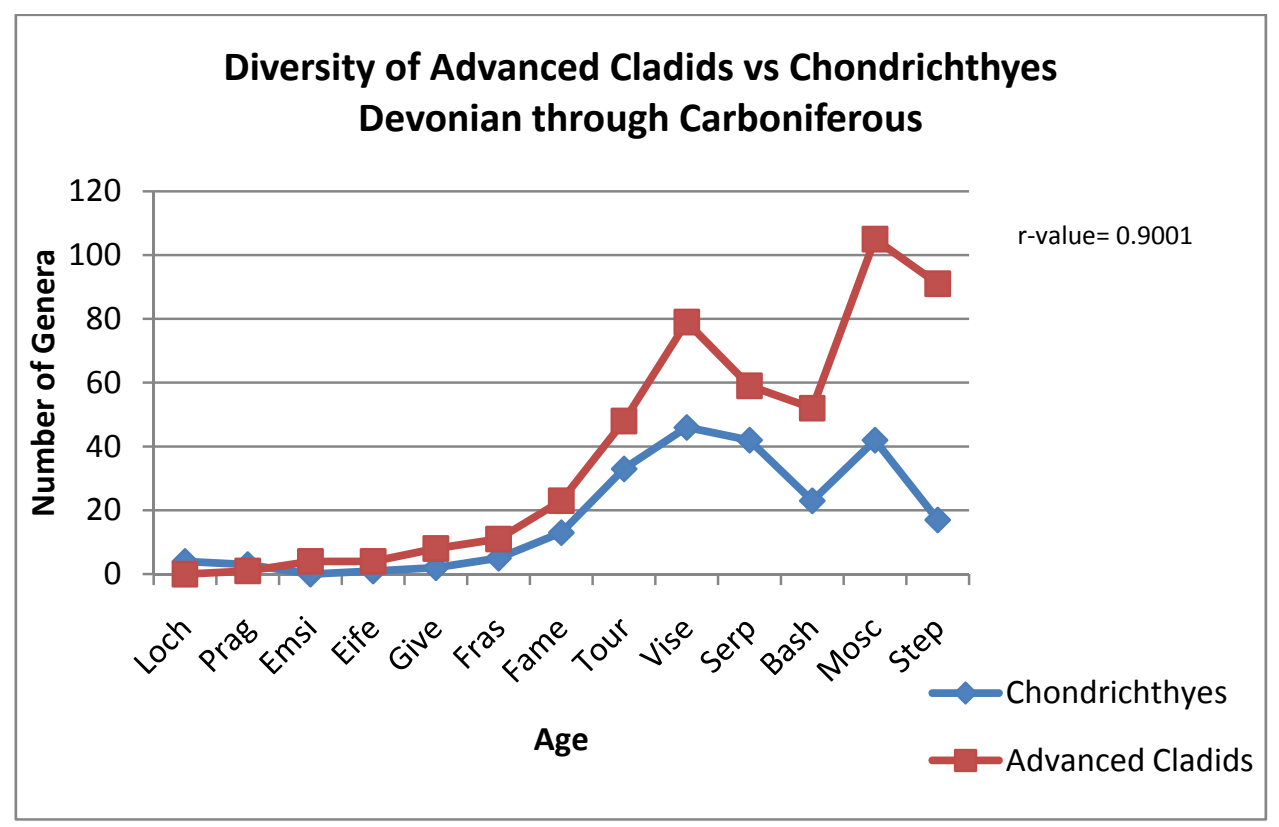

Figure 32. Diversity of advanced cladids versus chondrichthyes from the Devonian through the Carboniferous. Advanced cladids were increasing in number as the number of chondrichthyes was increasing. (Data from Sepkowski, 2002, Total diversity; Kammer and Ausich, 2006).

Cephalopods may have also played a role in predation on crinoids during the Middle to Late Mississippian. Nautiloids were present during that time but had decreased in numbers with the Devonian extinction. Ammonoids were becoming dominant in numbers. Both had chitinous beaks capable of duraphageous behavior (Brett and Walker, 2002). In matching the numbers of genera of ammonoids against the numbers of camerates and advanced cladids, it is noted that ammonoids parallelled the increase in numbers of advanced cladids. At the same time, the increase in numbers of ammonoids coincided with a decrease in the number of 
genera of camerates (Figure 33). This may, indicate a better adaptation of advanced cladids over camerates to attacks by ammonoids.

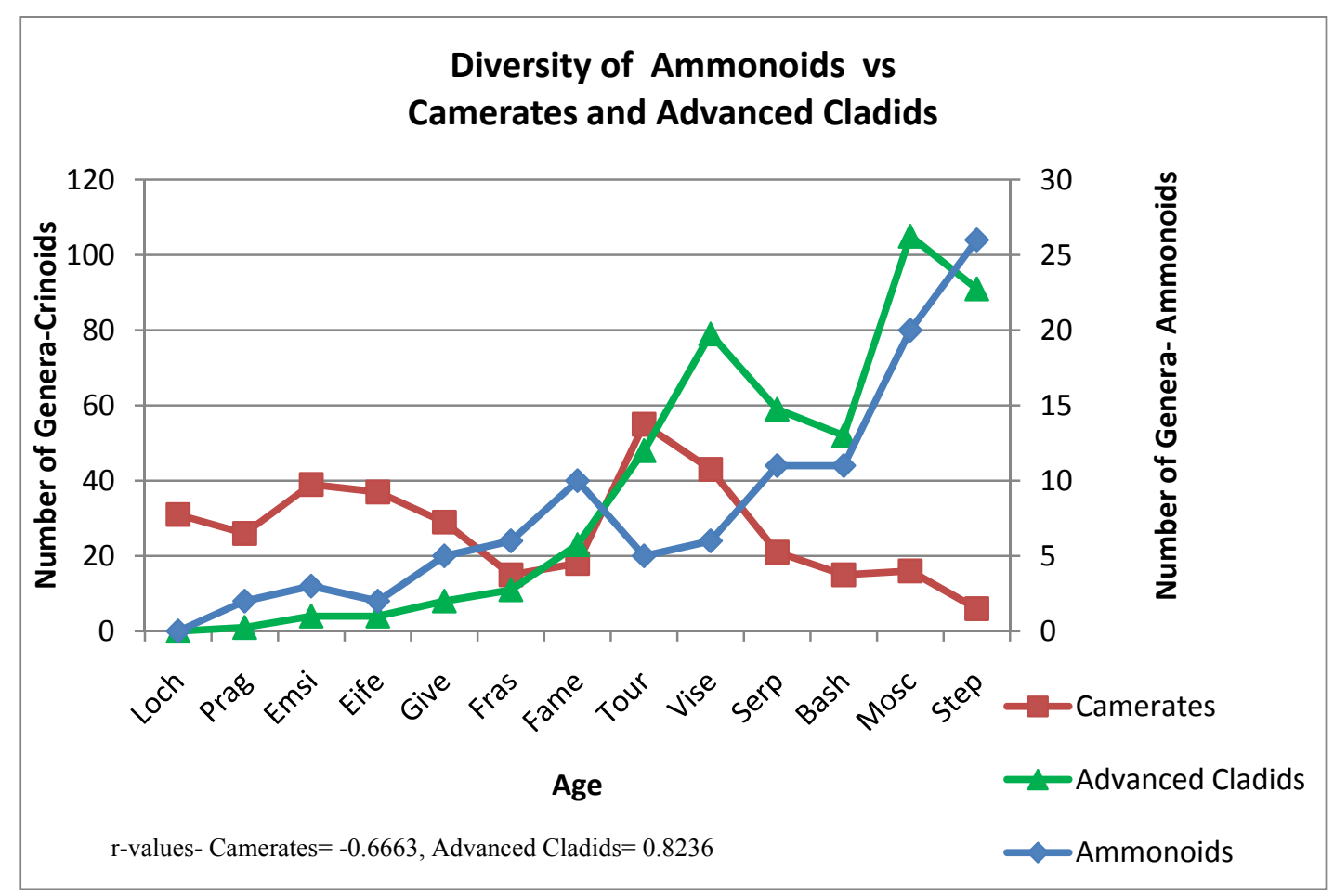

Figure 33. Diversity of camerates and advanced cladids compared to ammonoids from the Devonian through the Carboniferous. Advanced cladids parallel the increase in number of genera of ammonoids. At the same time, camerates decrease in numbers. This implies that camerates are negatively impacted by ammonoids while advanced cladids are not. (Data from Brett and Walker, 2002; Sepkowski, 2002).

Thicker shells and spines were developed as a generalized adaptation of marine invertebrate fauna to predators. Both cladids and camerates exhibited that change (Meyer and Ausich, 1983; Signor and Brett, 1984; Brett and Walker, 2002). In addition to the thicker calyx and tegmen plates, Signor and Brett (1984) described even further thickening of plates 
surrounding vital areas, reduction in size of vulnerable areas, as well as reduction of the entire thecal size. Spinosity began to increase during the Silurian and peaked in camerates during the Devonian. Following the Devonian extinction, spinosity in the camerates decreased throughout the Mississippian. Cladids began their increase in spinosity at the endDevonian extinction event; that increase continued until its peak during the Pennsylvanian (Figure 34).
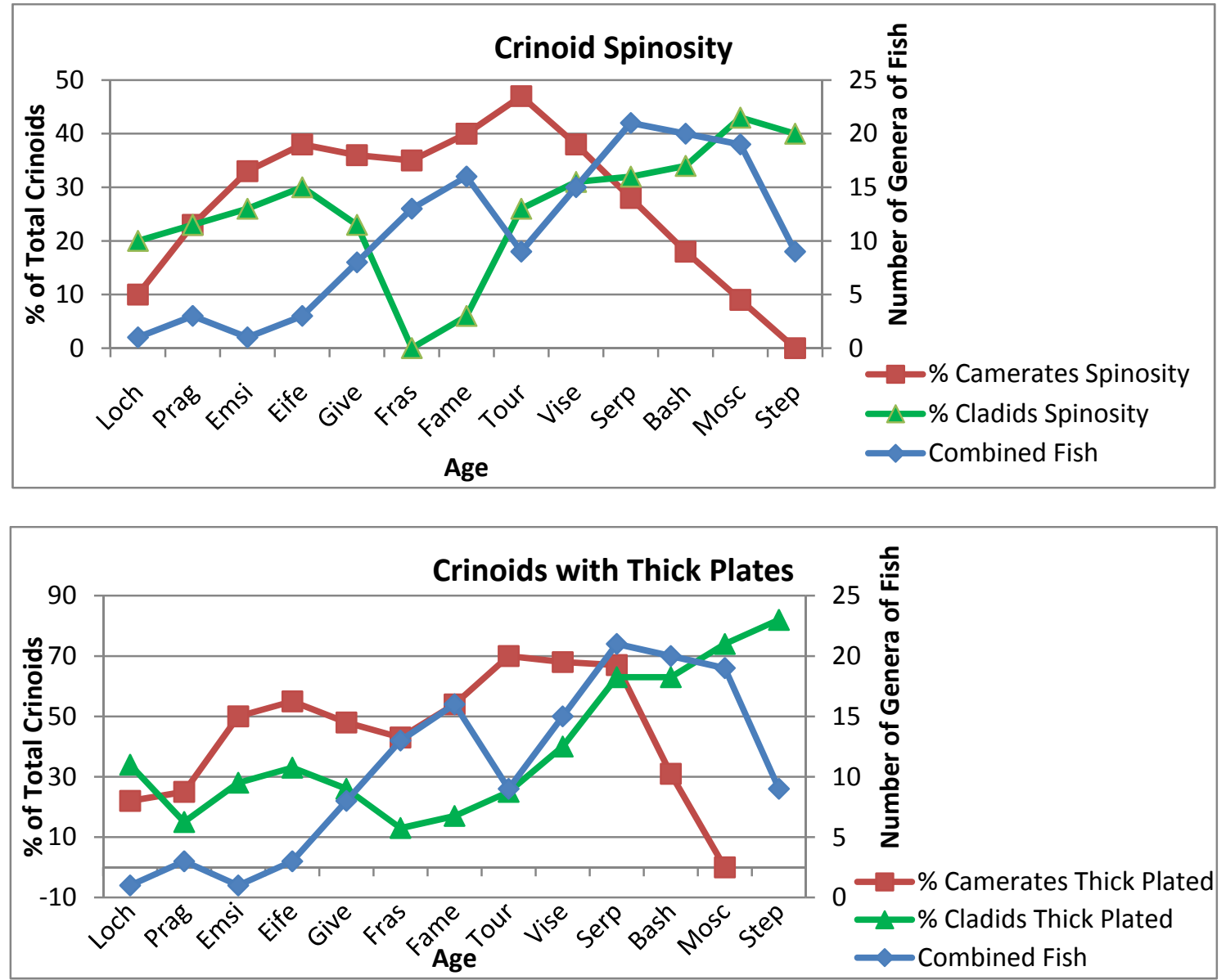

Figure 34. Spinosity and thick plated Paleozoic crinoids in response to durophagous fish. Note in cladids the relative decrease in spinosity with increasing plate thickness beginning in the Mississippian. Camerates decrease in both spinosity and plate thickness but this may be associated with a decrease in camerates, overall, for that time period. (Data extracted from Signor and Brett, 1984). 
Spines occur on the terminus of the anal sac calyces and on arms in crinoids. The relative number of cladids with this feature increased approximately $25 \%$ during the Devonian and rose to as high as $50 \%$ by the Pennsylvanian (Figure 34). The explanation for the apparent drop in spinosity at the end of the Late Devonian for cladids (Figure 34) is not known, but could be the lack of known taxa in 1984 when Signor and Brett published these data (personal communication, T. W. Kammer). Spine development in camerates began earlier but also dropped off early, through the Mississippian. Talarocrinus retained small spines into the Chesterian. Dichocrinus and Platycrinites had smooth plates. The Mississippian decrease may have been due to the overall decrease in camerates during that time period. The decrease in the number of crinoids with spines in all classes during the Late Paleozoic is likely to have been due to a diminution in the relative protection afforded by spines as compared to the heavy plating (Signor and Brett, 1984; Brett and Walker, 2002). Thicker and more rigid plates developed during and after the Devonian in all crinoids. All subclasses continued this trend, with $70 \%$ to $100 \%$ of genera exhibiting compact thick-plated calyces by the Permian. Again numbers of camerates with thickened plates, versus total crinoids, fell dramatically during the Mississippian, probably a reflection of their overall demise (Signor and Brett, 1984).

The shape and size of the anal sac in the cladids changed through the Paleozoic. Variations included length of the sac, the position of the anal opening and its function to house the gonads and gut (Lane, 1984; Kammer and Ausich, 2007a; Ausich and Kammer, 2010b). The length of the anal sac was especially pronounced in advanced cladids, being many times taller than the cup and even extending above the arms. This was in contrast to primitive 
cladids with short pyramidal sacs. Given the separation of the tip of the anal sac from the more vital organs and its ability to regenerate, survivability from predation would have been increased. Repositioning of the anal opening from the tip to the base of the anal sac would also have reduced the complexity required for its regeneration (Lane, 1984).

In addition to the change in shape and size, the function of the anal sac to accommodate the gonads was modified. Gonads would have been an attractive feature for predators from a nutritional standpoint. The anal sac may also have served as a brood chamber and the pores and slits between plates may have served as gonopores. Moving these functions away from the calyx would decrease the lethality of an attack. A predator could remove the anal sac, which could be regenerated, leaving behind the more critical calyx (Lane 1984; Waters and Maples, 1991). That may have been especially pertinent for the attachment of parasitic gastropods that positioned themselves over the shorter anal tube of camerates. The long, slender anal sac of advanced cladids would have made it more difficult for gastropods to attach (Bowsher, 1955; Gahn and Baumiller, 2002). Platyceratids had the ability to extract contents from the gut of crinoids before the full nutritional benefit to the crinoids occurred. Having gonads in addition to the distal gut in the anal sac, gametophagy as well as coprophagy would have occurred (Lane, 1984; Baumiller and Gahn, 2002). The loss of nutrients and decreased gametes would lessen the overall fitness (fecundity) of camerates over advanced cladids. The association of platyceratids with crinoids grew over the Paleozoic in a pattern that reflected cause and effect. The number of crinoid genera parasitized by platyceratids increased with the same trend as the increase in crinoid diversity (Baumiller and Gahn, 2002) (Figure 35). 


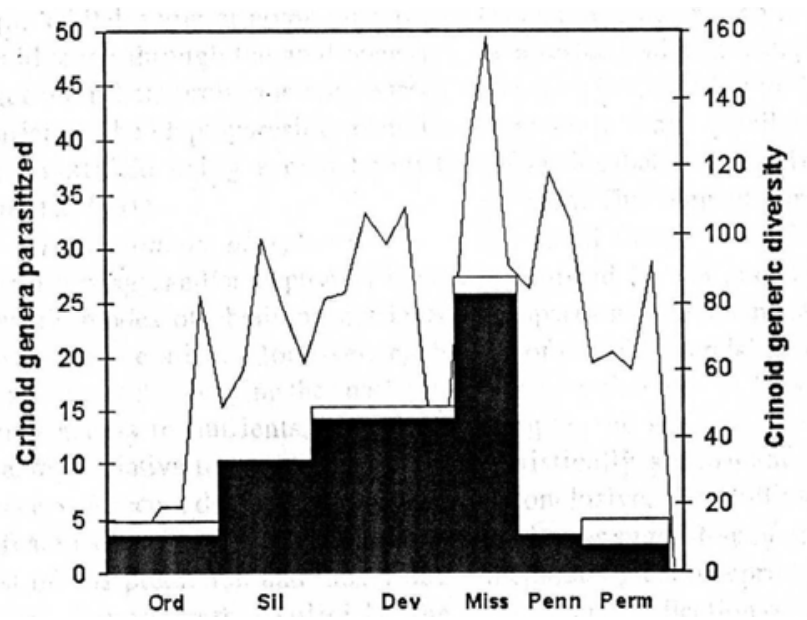

Figure 35. Distribution of crinoid genera parasitized by platyceratids during the Paleozoic. Solid bars: co-occurrence of crinoids and platyceratids. Open bars: inferred associations based on scarring. Upper curve: Paleozoic crinoid diversity from Sepkoski’s Compendium (Baumiller and Gahn, 2002).

Another development allowing crinoids to survive predation was the ability to regenerate arms. Gahn and Baumiller (2005) analyzed the frequency of regenerated arms from a Kinderhookian site and found nine percent of the specimens examined exhibited arm regeneration. Most of their studied specimens were camerates with only six percent cladids. That does not show a differential ability between camerates and cladids in the ability to regenerate arms, but Baumiller and Gahn ((2004) and Gahn and Baumiller (2005)) concluded that predation was increasing into the Middle Paleozoic and was a driving force of predatordriven evolution. The number of crinoids with regeneration accelerated from the Silurian through the Devonian, then stabilized somewhat through the Devonian, and increased again during the Mississippian (Baumiller and Gahn, 2004). A general correlation can be seen between the number of durophagous fish and the percentage of crinoids found with regenerated arms (Figure 36). 


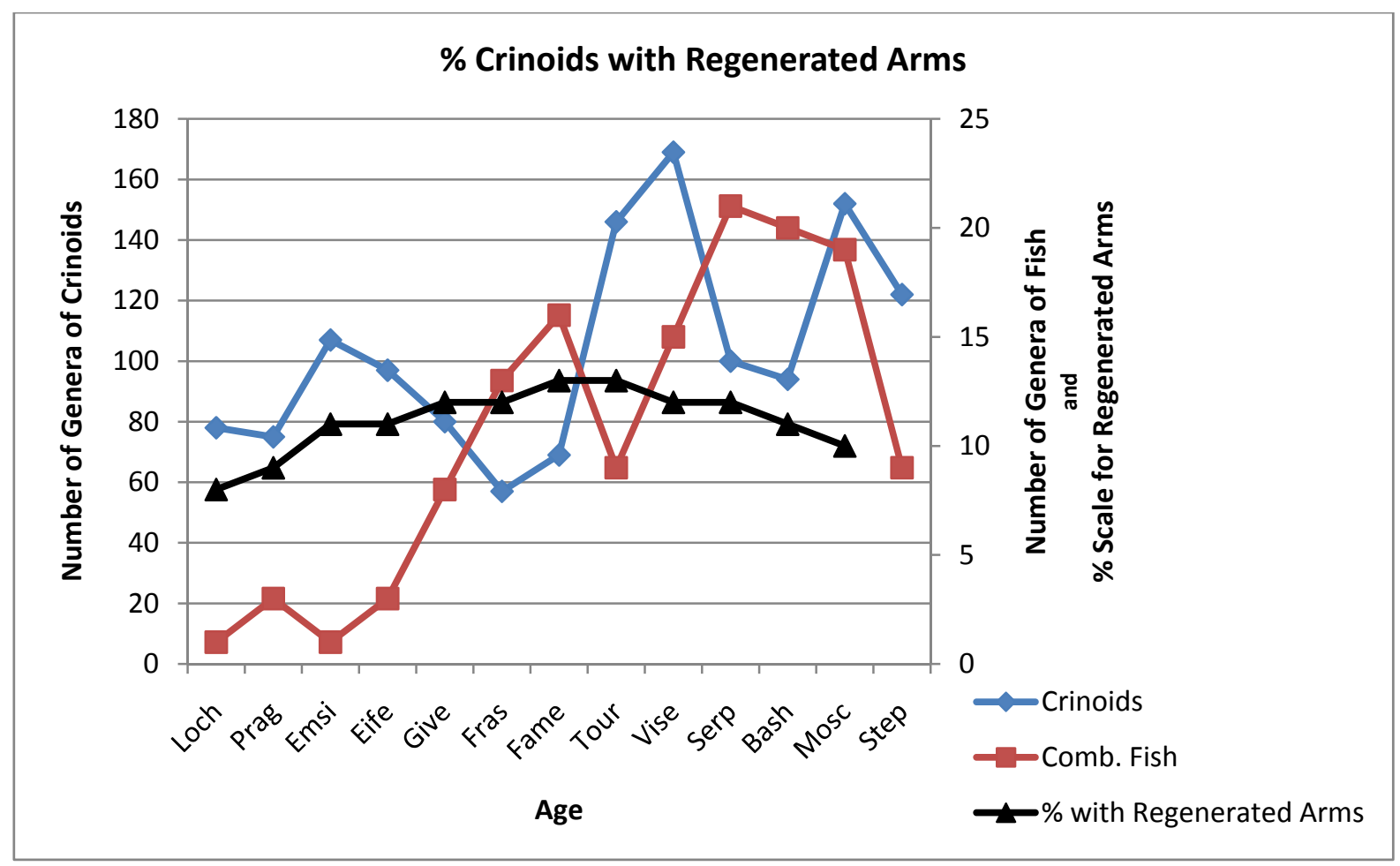

Figure 36. Per cent of crinoids found in Paleozoic crinoids with regenerating arms resulting from non-lethal predation. Compare to rise and decline in number of fish. (Data adapted from Baumiller and Gahn, 2004).

Past authors have not always accepted predation as a significant factor in the ecology of Paleozoic crinoids (Signor and Brett, 1984; Baumiller, 2008). However, some authors have offered evidence in support of the concept. The finding of crinoid plates in the gut of Paleozoic fish and the development of predatory defenses such as spines and thicker plates are two important types of eveidence (Signor and Brett, 1984; Brett and Walker, 2002). Baumiller (2008) explained that up until 1920 crinoids were thought to be "immune" from predation, but modern investigation has proven otherwise. Laudon (1957) projected that a scarcity of crowns and intact thecal plates, leaving only columnals behind, was evidence of grazing by predators. Springer (1920) and Hattin (1958) included regenerated arms and 
spines of Paleozoic crinoids as evidence of predation. Ubaghs (1978) included the autotomy of arms regeneration as a common finding. Evidence of predation of Paleozoic crinoids thus appears to be growing.

All of the changes in crinoid morphology discussed here appear to have followed a parallel increase in predatory behavior within the syncology of the marine environment. All changes appear to have begun before the Meramecian and accelerated during that time period.

Following the peak of diversity of crinoids in the Mississippian, the number of total crinoid genera began to fall. The associated distribution in subclasses of crinoids changed at the same time. Camerates gradually disappeared while advanced cladids became dominant (Sepkoski, 1984; Ausich et al., 1994; Baumiller and Gahn, 2002).

Overall, camerates either possessed characteristics that led to their demise or failed to develop characteristics that would have improved their survival. That is, they retained a larger calyx containing desirable attractive components (gut and gonads) to predators. They had a restricted filter feeding morphology intolerant to changes in food particle size and sediment clogging. They lacked muscles to clear sediment from their arms. They retained a short anal tube making it easier for parasites such as gastropods to attach. In combination, these factors made them less competitive with advanced cladids. 


\section{Environmental Change During the Meramecian}

In addition to morphological changes in crinoids through the Meramecian and into the Chesterian, environmental changes occurred as well. As previously noted, various authors have suggested sea level variation as having influenced the distribution of taxa and numbers of crinoids through this time period. Review of the literature, however, does not appear to show specific geological evidence of association of sea level variation and crinoid morphological variation, along with associated geological evidence, that could demonstrate a cause-and-effect scenario. Again, the superimposition of these factors in the Illinois Basin offers an opportunity to provide evidence of those previously suggested hypotheses.

Ross and Ross (1988) documented second order sea level cycles in the Illinois Basin. These sea level cycles correlated with the same sequences globally, including northwestern Europe, the Moscow Basin and southern Urals, along with the Mississippi Valley and Kentucky. It appears that sea level rose during early deposition of the Salem Limestone; fell during late deposition of the Salem and into the formation of the lower St. Louis. It remained at lowstand through the middle St. Louis, rising again in the upper St. Louis. At the end of the St. Louis deposition, sea level fell again going into the Ste. Genevieve (Figure 37). The low stand in sea level during the deposition of the lower part of the St. Louis is consistent with the finding of evaporites in the Harris Stone Quarry as reflected by the collapse breccias (Figure 38). 
MISSISSIPPI VALLEY

AND
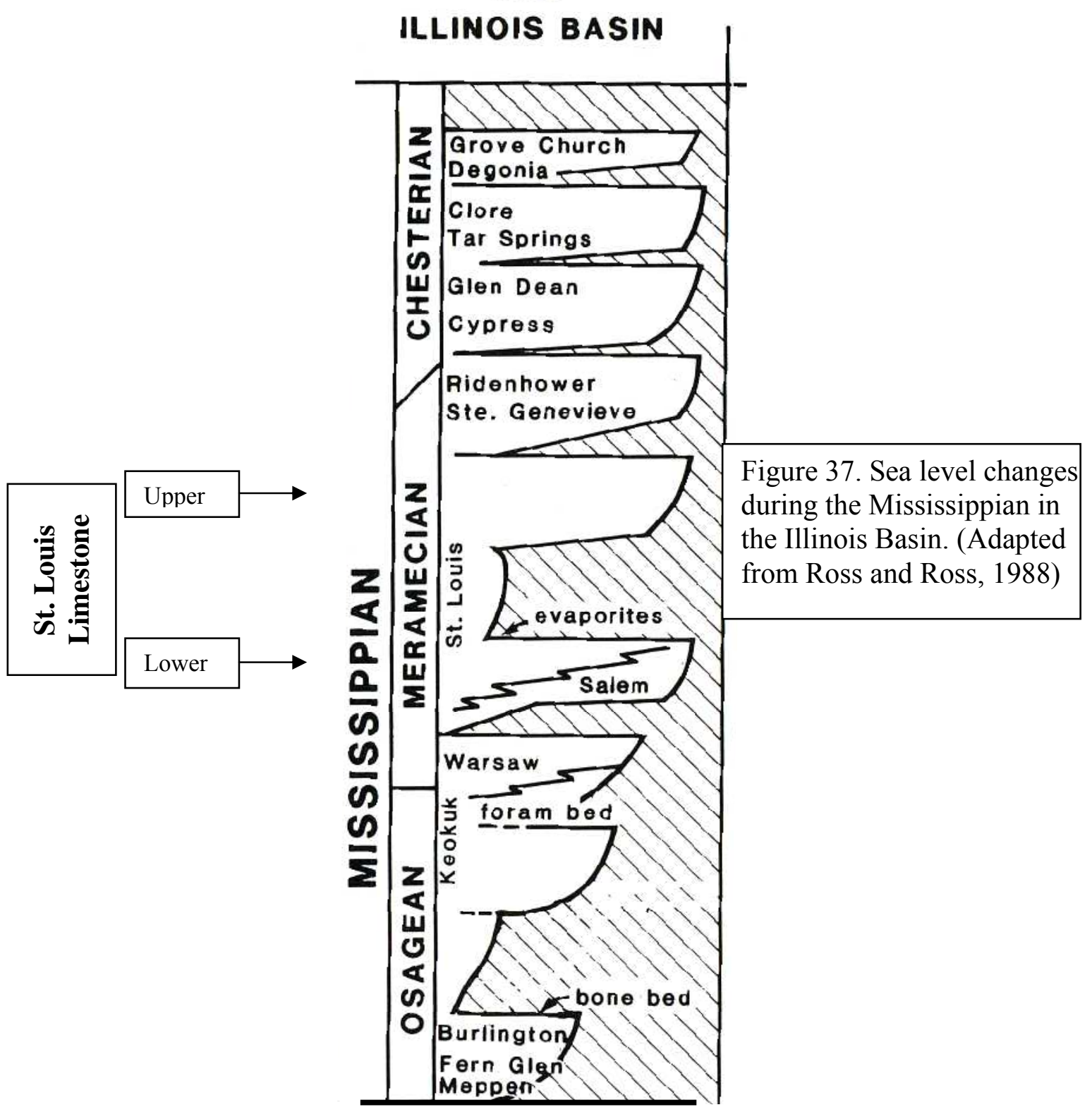

LOW---------HIGH

Sea Level 


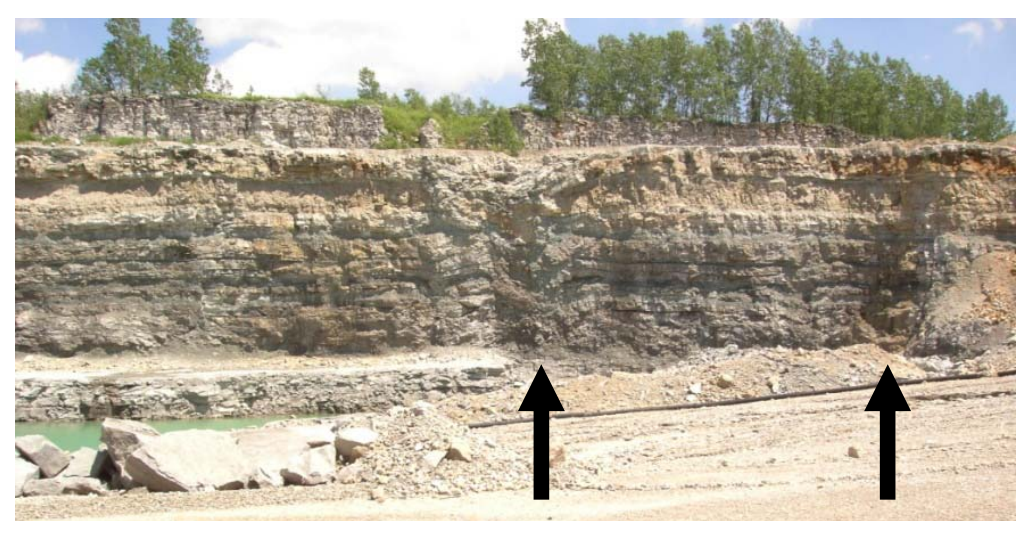

Figure 38. Collapse breccias at Harris Stone Quarry, Bainbridge, Indiana. The entire wall seen is St. Louis Limestone measuring 75 feet(22.75 meters) in height. Arrows point to two areas of collapse.

Collapse breccia was posited by Smith et al. (1961) and Collinson et al. (1979) as resulting from either the dissolution of evaporites leading to loss of continuity and collapse or tectonic activity causing a submarine rock slump. Given the large amount of evaporites present in the lower St. Louis (Treworgy, 1990), the assumption of subaerial exposure and/or increasing salt concentration with evaporation could be a possibility. Evaporites occur in that setting. McGregor (1954) portrayed a large amount of gypsum and anhydrite throughout the lower St. Louis Limestone (Figure 39). This coincides with the drop in sea level portrayed by Ross and Ross (Figure 37). The combination of evaporites in such abundance and the evidence of sea level drop by Ross and Ross leaves little doubt about subaerial exposure, concentrating salinity and decreasing habitat space for crinoids during the early to middle St. Louis Limestone deposition. (Refer to the St. Louis section within the Geologic Setting chapter for further evidence of subaerial exposure.) This must have been accompanied with climate conditions, little or no rainfall, to produce evaporites (personal communication, Richard Smosna). The fact that evaporites were formed indicate those conditions existed. 


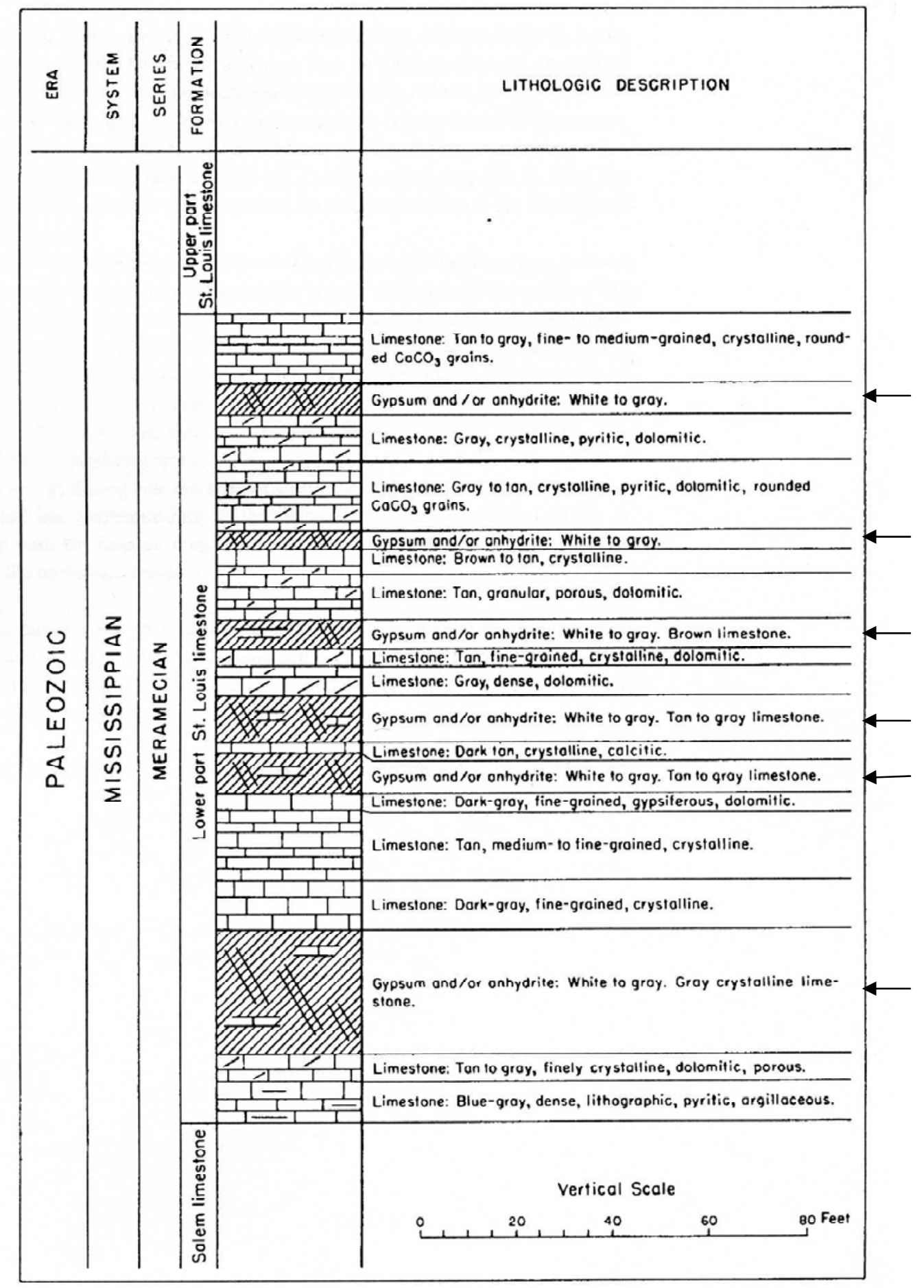

Figure 39. Stratigraphic section of the lower to middle St. Louis Limestone in subsurface of southwestern Indiana. Note intermittent layers of gypsum and anhydrite indicated by arrows.. (McGregor, 1954) 
Crinoids are very intolerant to changes in salinity. Instead of having a controlled osmotic gradient provided by fluid surrounding body tissue like most animals, echinoderms have a permeable external cover that allows for free flow of ions from the external environment. As a result, an extraordinary amount of effort is required for crinoids to maintain osmotic stability. This characteristic places crinoids in a precarious situation when dealing with environmental changes in salinity (Meglitsch, 1967). In fact, crinoids tolerate only a very narrow range of salinity and will not survive outside those boundaries (Ausich and Simms, 1999; Kammer and Ausich, 2006). The impact on crinoids of the increases in ionic concentrations during the early to middle St. Louis Limestone deposition would have been dramatic, thus preventing their occurrence in the Illinois Basin at that time.

Periodic transgressions and regressions occurred throughout the Mississippian. As seen in Figures 37 and 40, most of the Mississippian rock record in the Illinois Basin experienced relatively short regressions compared to the longer transgressions. However, the regression occurring in the early to middle St. Louis was relatively prolonged (Ross and Ross, 1988) (Figure 40). That prolongation would have resulted in a very shallow sea persisting over a more extended time than usual, a prolonged period of reduced habitat and increased salinity that would have exposed crinoids to adverse circumstances. That adversity would have been so severe that crinoids would have been excluded from the Illinois Basin and pushed towards the open ocean to the south and west. Crinoid diversity was lower in the upper St. Louis, perhaps because of limited recruitment from outside the basin (Kammer, personal communication). The pronounced dip in the number of crinoids during that time period could be explained by that adverse environment. The number of crinoids at any given time would 
have been dependent on the amount of deeper water with conditions favorable to them. Very shallow, high salinity conditions would have precluded crinoids. As the sea level rose, crinoids from deeper offshore areas that allowed them to survive would return as conditions improved. These evaluations of diversity reflect only "snapshots" of crinoid diversity. The intervals would likely reveal periods of near or total loss of crinoids at times followed by resettlement of crinoids from deeper refuge areas. Crinoid diversity success or failure in the Illinois Basin parallels sea level changes during the Meramecian. The coincidence of the prolonged drop in sea level and the decrease in crinoid diversity, followed by a rise in sea level and an increase in crinoid diversity, may indicate a cause-and-effect relationship.

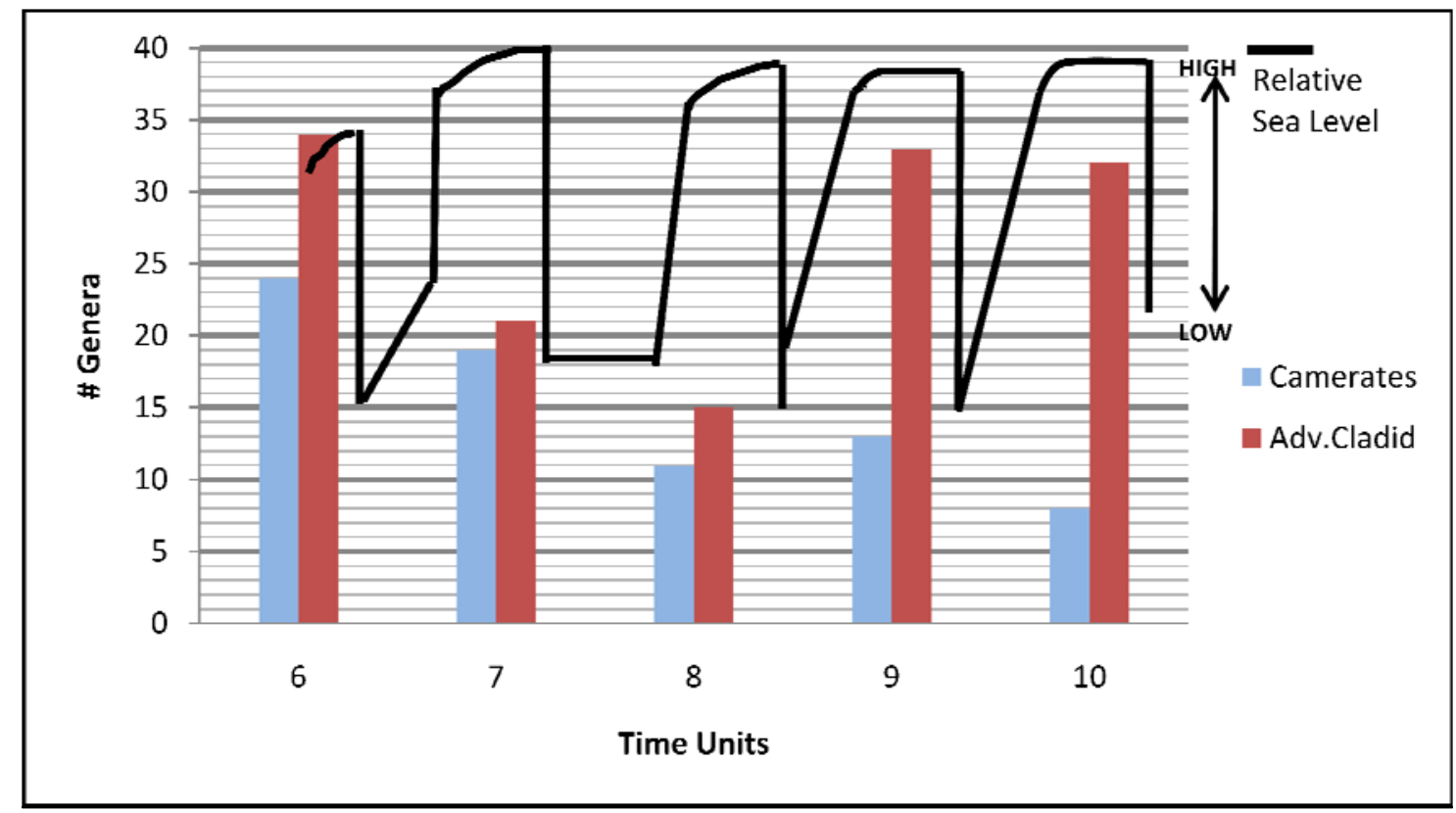

Figure 40. Sea-level change and number of camerate and advanced crinoid genera in the Illinois Basin. Time Units: 6, upper Keokuk, lower Warsaw; 7, upper Warsaw, Salem; 8, St. Louis; 9, Ste. Genevieve and early Chesterian; and 10, middle Chesterian. (Data for graphs derived from Kammer and Ausich for diversity data, unpublished; Ross and Ross, 1988 for sea level curve) 


\section{Discussion}

The transition of dominance from camerates to advanced cladids has been well documented. The question of cause and effect has persisted. As stated previously, hypotheses have been offered including predation and sea level changes. Convincing arguments have not previously been made, however, that these two factors were indeed associated with that transition. The timing and proximity of those potential influences are demonstrated here.

The evolutionary development of duraphagous fish occurred in the Devonian but remained at a low level until the Middle Mississippian. Chondrichthyes, which would have been the major threat to crinoids, peaked in the Middle Mississippian. Crinoid diversity had its peak in growth just prior to the increase in chondrichthyes. Crinoid defenses such as thick plates with spines improved along with the increase in the numbers of duraphagous fish, indicating a response to the threat that they posed. Camerates had a decrease in the number of taxa with thick plates and spines at the end of the Mississippian, but this may be exaggerated by the overall decrease in the number of camerates. With those same attributes of thickened plates and spines, advanced cladids continued to increase in numbers.

The changes in plate thickness and abundance of spines along with the ability to regenerate arms would have helped camerates and advanced cladids alike. The additional evolutionary advantage in advanced cladids of being able to regenerate anal sacs would have given them an edge in survival. Advanced cladids would have been favored over camerates because of their ability, already in place, to regenerate anal sacs and to relocate vital structures such as gonads to less life-threatening positions. In addition, advanced cladids were aided in 
movement by the development of muscular arms, which camerates lacked. The relative threat of parasites such as platyceratids was compensated for in advanced cladids by the development of a longer anal sac making it more difficult for them to attach. These additional characteristics would have allowed the advanced cladids to survive predation and parasitism beyond what camerates were able to tolerate.

Changes in feeding structures allowing for a broader diet, and the ability to clean the sediment off their arms with muscles, gave advanced cladids an advantage. Anatomical adaptations which allowed for better oxygen uptake, increased metabolism, increased ability to detect food and assess water quality as described by Lane (1972) may have added to the overall advantage of advanced cladids over camerates in a struggle to survive. It is noted that the number of genera of both camerates and advanced cladids fell during the time of St. Louis deposition. Camerates never recovered fullyfrom their depletion in the Middle Meramecian. Advanced cladids became dominant and flourished into the Permian. The differential in survivability may have allowed the advanced crinoids to go through the bottleneck of the temporary hostile environment of the Salem to St. Louis regression to outcompete camerates in the Chesterian.

Another shift in the environment for crinoids' habitat that took place in the Middle Mississippian was sea level fall. As documented by Ross and Ross (1988), transgressions and regressions were taking place throughout the Mississippian in the Illinois Basin. Transgressions or regressions often coincided with the changes in formations as they were deposited. A different pattern from most of the Osagean and Meramecian occurred in the late 
Salem, early and middle St. Louis. During that time regression was prolonged resulting in a larger impact on the environment. Subaerial exposure with more evaporite formation and shallower lagoons of higher salinity resulted, compared to preceeding and following regressions of the Meramecian and Chesterian. That would have resulted in a decreased habitat space and a very stressful environment over a prolonged period for the salinitysensitive crinoids.

In summary, advanced cladids had previously acquired adaptations that provided for increased survivability compared to camerates in the face of increasing predation, sediment influx, and a prolonged drop in sea level. Changes in the environment had probably occurred previously that led to some adaptation in camerates. Their adaptation was too little and too late. Advanced cladids not only adapted to out-compete camerates but to cope with environmental changes as well. The benefits derived from the combination of those evolutionary pressures placed them in a more advantageous position to survive the impact of predation and sea level drop. This reversed the previous dominance of camerates over advanced cladids from which the camerates never recovered. 


\section{Conclusions}

The details of crinoid systematics and evolutionary paleoecology of the Middle Mississippian have remained unclear in recent decades. What has been clear is that a significant transition in crinoid macroevolutionary patterns occurred during deposition of the Meramecian St. Louis Limestone. Several researchers have hypothesized potential influences on that transition in crinoids, but no definitive study had been done to explain the changes.

Hindering factors were present that limited a comprehensive study of crinoids of the St. Louis Limestone until this time. A significant amount of confusion existed regarding the exact placement of the Osagean, Meramecian and Chesterian boundaries until those were clarified recently (Maples and Waters, 1987; Kammer et al., 1990). The boundaries, especially the upper boundary of the St. Louis, were in constant debate through most of its nomenclatural history. In addition, a clearer picture of crinoid morphology has evolved over two centuries. Perhaps the most important event that facilitated a more accurate and thorough study recently was the collection of a large number of crinoid specimens from the Harris Stone Quarry that was definitively established as St. Louis Limestone in Bainbridge, Indiana.

Data and conclusions of this study are as follows:

1. The extent of the Meramecian includes the upper Warsaw, Salem and St. Louis limestones. The lower boundary of the St. Louis is its contact with the Salem Limestone. The upper boundary with the Ste. Genevieve Limestone is the upper boundary of the Lost River Chert Bed Member, which also defines the Meramecian/Chesterian boundary. 
2. Lithologies of the Salem, St. Louis and Ste. Genevieve limestones reflect a demonstrable difference in their paleo-environments. The Salem Limestone consists of grainstone and packstone with some mudstone and wackestone in the lower layers trending toward increasing oolitic and fossiliferous grainstone in the upper layers. Well sorted and abraded coarse skeletal grainstone with crossbedding occur. These characteristics indicate a high energy environment such as tidal channels, intervening shoals and an adjacent lagoon. The St. Louis Limestone is comprised of a preponderance of mudstone, skeletal wackestone and packstone and a large amount of gypsum and anhydrite. It exhibits cryptalgal features, burrows, desiccation structures, birdseye and cross-lamination structures. These characteristics indicate shallow, subtidal, open to restricted lagoonal and supra-tidal-sabkha facies. The Ste. Genevieve Limestone is comprised of mudstone and grainstone but has a preponderance of oolitic limestone. Structures include dunes, herringbone crossbedding, and a high degree of sorting. Again, this indicates a high energy environment around shoals. These changes in facies between the Salem, St. Louis and Ste. Genevieve limestones reflect a transition from a high energy, deeper water environment to a low energy, shallow, lagoonal facies with intermittent subaerial exposure and a return to another high-energy, deeper water environment.

3. The crinoid fauna that has been designated in the past to be the St. Louis fauna was somewhat confused by inconsistent boundary designations leading to inclusion of Ste. Genevieve Limestone specimens, incorrect misunderstood taxonomic designations and mislabeling of museum specimens. Given the benefit of the collection made by Robert Howell at the Harris Stone Quarry in Bainbridge, Indiana, 
which is a definite St. Louis Limestone site, a more precise definition of the St. Louis fauna can be made at this time. Based on analysis of this collection and other specimens, seventeen crinoid species that were designated as being from the St. Louis are retained. Three crinoid species that were not designated as St. Louis but identified elsewhere were added to the St. Louis. One new species, Armenocrinus howelli n. sp. was discovered within the collection from the Harris Stone Quarry. Three crinoid species including Cyathcrinites macadamsi (Miller and Gurley, 1895), Poteriocrinites arrectarius (Miller and Gurley, 1896) and Aphelecrinus peculiaris (Worthen, 1883) were synonymized into Cymbiocrinus dactylus (Hall, 1859), Phacelocrinus vanhornei (Worthen, 1875) and Aphelecrinus scolparius (Hall, 1859), respectively. Eight crinoid species previously listed as St. Louis Limestone crinoids were deleted from the list of St. Louis Limestone crinoids on the basis of modern taxonomy.

4. The transition in dominance of camerates in the Osagean to advanced cladids in the Chesterian has been known for some time. Identification of factors that might have influenced that change, however, has not been specifically addressed. It appears that three major factors were involved: a) previous adaptations in morphology that allowed advanced cladids to have an increased ability over camerates to withstand adverse environmental impacts; b) development of durophagous predators during the Mississippian; c) a prolonged sea level drop (regression) during deposition of the lower St. Louis Limestone.

5. Morphological adaptations occurred in both camerates and advanced cladids. Advanced cladids developed alternative strategies such as adaptations in feeding 
filter density by arm pinnule redistribution and ambulacral groove modification. They also developed arm muscles which would assist in clearing sediment from their feeding filter by rapid arm motion. Camerates and advanced cladids developed the ability to regenerate arms and anal sacs. Advanced cladids gained the extra benefit of repositioning their gonads and much of their gut into a longer anal sac. The tendency of predators to feed on gut and gonads resulted in lethal damage to camerates as they retained those structures within the calyx. On the other hand, an attack on an advanced cladid would have removed the anal sac only, which could be regenerated. The longer anal sac of the advanced cladids resisted attachment by parasites such as platyceratid gastropods. The smaller anal tube of camerates facilitated attachment by platyceratids. As a result, the metabolic and reproductive consequences for camerates were much more dire from parasitism by platyceratids. Both camerates and advanced cladids developed thicker plates and spines during the Devonian that would have provided a comparable mechanism of defense. Clearly, predators were becoming a threat to crinoids.

6. Durophagous fish developed during the Devonian. Crinoids show a decline with an increase in placoderms during the late Devonian. However, placoderms were lost in the Frasnian/Famennian extinction event. Following that event, a dramatic increase in chondrichthyes, which were a significant threat to crinoids, occurred. Camerates declined dramatically with the increase in genera of chondrichthyes while the advanced cladids remained relatively unaffected. This implies a differential susceptibility between camerates and advanced cladids toward the threat from chondrichthyes. The relocation of vital structures into the anal sac of advanced 
cladids may have been a important factor. Ammonoids, another durophagous predator, were also increasing during the Mississippian. The same pattern of increasing numbers of ammonoids occurring with decreasing numbers of camerates and increasing numbers of advanced cladids demonstrates a possible cause and effect relationship. Additional evidence of the impact of predators is demonstrated by studies of the number of crinoids found with regenerated arms. As the number of predators increased, the number of crinoids with regenerated arms rose. As predators decreased, the number of crinoids with regenerated arms fell.

7. Sea level changes during the deposition of the upper Salem and the St. Louis limestones were unusual compared to those transgressions and regressions before and after this time period. A prolonged regression occurred during the St. Louis deposition (evidence of that event is demonstrated above in 2 of this section). The impact on crinoids would have been dramatic. An evaporitic environment would have been very stressful for crinoid survival in the Illinois Basin. Increasing salinity would have precluded habitation by crinoids. Only those in deeper, more stenohaline water would have survived to re-inhabit the Illinois Basin as later transgression took place. That exposure would have been enough to create an evolutionary bottleneck, allowing the most fit to survive and the lesser adapted to perish.

In the end, the transition from the dominance of camerates to dominance of advanced cladids did occur as indicated by the fossil record. As is always the case in paleontology, hypotheses based on data and inferences can be constructed to explain past events. In this work, the technique of superimposition of events with the addition of potential or even probable consequences is presented. Direct cause and effect relationships are difficult to 
establish from the rock and fossil record. As further research is done, perhaps a clearer and more precise explanation will develop. For now, this work provides a plausible explanation for transition from camerates to advanced cladids through the Middle to Late Mississippian. 


\section{References}

Angelin, N.P. 1878. Iconographia Crinoideorum: in stratis Sueciae Siluricis fossilium:

Samson and Wallin, Holmiae, 62 p., 29 pl.

Atherton, E., Collinson, C., and Lineback, J.A. 1975. Mississippian System, In Willman, H.B., et al. (eds.), Handbook of Illinois Stratigraphy. Illinois State Geological Survey Bulletin 95, p. 123-163.

Ausich, W.I. 1980. A model for niche differentiation in Lower Mississippian crinoid communities. Journal of Paleontology, 54:273-288.

Ausich, W.I. 1988. Evolutionary convergence and parallelism in crinoid calyx design. Journal of Paleontology, 62:906-916.

Ausich W.I. 1996. Crinoid plate circlet homologies. Journal of Paleontology, 70:955-964.

Ausich, W.I. 1997. Regional encrinites: a vanished lithofacies, In Paleontological events; stratigraphic, ecological, and evolutionary implications (eds.), C.E. Brett, G.C. Baird, Columbia University Press, New York (USA).

Ausich, W.I. 1998. Early phylogeny and subclass division of the Crinoidea (Phylum Echinodermata). Journal of Paleontology, 72:499-510.

Ausich, W.I. 1999. Lower Mississippian Edwardsville Formation at Crawfordsville, Indiana, USA, In, H. Hess, W.I. Ausich, C.E. Brett, M.J. Simms, Fossil Crinoids, Cambridge University Press, Cambridge, United Kingdom (GBR), 275 p.

Ausich, W.I. and BABCOCK, L.E. 1998. The phylogenetic position of Echmatocrinus brachiatus, a probable octocoral from the Burgess Shale. Palaeontology, 41:193-202.

Ausich, W.I. and BABCOCK, L.E. 2000. Echmatocrinus, a Burgess Shale animal reconsidered. Lethaia, 33:92-94. 
Ausich, W.I., and Baumiller, T.K. 1993. Taphonomic method for determining muscular articulations in fossil echinoderms: a test for the occurrence of muscles in Lower Mississippian cladids crinoids. PALAIOS, 8: 477-484.

Ausich, W.I., and Kammer, T.W. 1990. Systematics and phylogeny of the late Osagean and Meramecian crinoids Platycrinites and Eucladocrinus from the Mississippian stratotype region.

Journal of Paleontology, 64:759-778.

Ausich, W.I. and Kammer, T.W. 2009. Generic concepts in the Platycrinitidae Austin and Austin, 1842 (Class Crinoidea). Journal of Paleontology, 83:694-717.

Ausich, W.I. and Kammer, T.W. 2010. Generic Concepts in the Batocrinidae Wachsmuth and Springer, 1881, (Class Crinoidea). Journal of Paleontology 84:32-50.

Ausich, W.I. and Kammer, T.W. 2010b. Tubes, sacs, cone, pyramids, and proboscises: Toward a homology-based understanding and terminology for plated, erect hindgut structures among the Crinoidea, p. 115-122. In: Harris, L. G., Boetger, S. A., Walker, C. W. M. P. Lesser, eds., Echinoderm: Durham: Proceedings of the $12^{\text {th }}$ International Echinoderm Conference, August 2006, Durham, New Hampshire. Taylor and Francis Group, London.

Ausich, W.I., Kammer T.W. and Baumiller, T.K. 1994. Demise of the middle Paleozoic fauna: a single extinction event or rapid faunal turnover?. Paleobiology, 20:345-361. Austin, T. and Austin, T. 1842, XVIII. Proposed arrangement of the Echinodermata, particularly as regards the Crinoidea, and a subdivision of the Class Adelostella (Echinidae). Annals and Magazine of Natural History, ser. 1, 10:106-113. Austin, T., and Austin, T. 1843-1847. A monograph on recent and fossil Crinoidea, with 
Figures and descriptions of some recent and fossil allied genera: London and Bristol, v. 1, 2, p. 1-32, pl.1-4, frontispiece (1843); v. 3, p. 33-48, pl. 5-6 (1844); v. 4, p. 49-64, pl. 7-8 (1845); v. 5, p. 65-80, pl. 9-10 (1846); v. 6-8, p. 81-128, pl. 11-16 (1847); 128 p.

BAMBACH, R.K. 2002. Supporting predators: Changes in the global ecosystem inferred from changes in predatory diversity: In The fossil record of predation, eds., Kowalewski, M. and Kelly, P. H. The Paleontological Society Papers, 8:319-351.

Bамвасн, R.K. 1977. Species richness in marine benthic habitats through the Phanerozoic. Paleobiology, 3:152-167.

Bambach, R.K., Knoll, A.H., and SepKoski, J.J. 2002. Anatomical and ecological constraints on Phanerozoic animal diversity in the marine realm. Proceedings of the National Academy of Sciences, 99:6854-6859.

BAssLer, R.S. 1938. Pelmatozoa Palaeozoica: In Quenstedt, W., ed, Fossilium catalogus, I:

Animalia. Part 83: W. Junk, s'Gravenhage, 194 p. (reprinted, 1973)

Bassler, R.S. and Moodey, M.W. 1943. Bibliography and Faunal Index of Paleozoic Pelmatozoan Echinoderms. Geological Society of America Special Paper 45, p. 734.

Bates, R.E. 1932. Underground features of Sinking Creek, Washington County, Indiana. Indiana Academy of Science Proceedings for 1931, 41:263-268.

Bather, F.A. 1899. A phylogenetic classification of the Pelmatozoa. British Association for the Advancement of Science (1898), p. 916-923.

Baumiller, T.K. 1993. Survivorship analysis of Paleozoic Crinoidea: effects of filter morphology on evolutionary rates. Paleobiology, 19:304-321.

Baumiller, T.K. 2008. Crinoid ecological morphology. Annual Review of Earth and Planetary Sciences, 36:221-249. 
BAUMiLler, T.K. and GAHN, F.J. 2002. Fossil record of parasitism on marine invertebrates with special emphasis on the platyceratid-crinoid interaction: In Kowalewski M.and Kelly, P.H. (eds.), The fossil record of predation. Paleontological Society Papers, 8:195209.

Baumiller, T.K. and Gahn, F.J. 2004. Testing predator-driven evolution with Paleozoic crinoid arm regeneration. Science, 305:1453-1455.

Baumiller, T. K. and Messing C.G. 2007. Stalked crinoids locomotion and its ecological and evolutionary implications. Palaeontologia Electronica, http://palaeo-electronica.org, 10:1-10.

BeEde, J. W. 1906. Fauna of the Salem Limestone of Indiana, Echinodermata. Indiana Department of Geology and Natural Resources for 1905, 1906, 30th Annual Report: p. $1243-1270$.

Benton, M. J. 2005. Vertebrate Palaeontology, Third Edition, Blackwell Publishing. Malden, Massachussetts. $455 \mathrm{p}$.

Bethke, C.M., Reed, J.D., Oltz, D.F. 1990. Long-range petroleum migration in the Illinois Basin: In Leighton, M.W., Kolata, D.R., Oltz, D.F. and Eidel, J.J. (eds.), AAPG Memoir, $51: 455-472$.

Bigsby, J. J. 1868. Thesaurus Siluricus; the flora and fauna of the Silurian period. With Addenda (from recent acquisitions): London, J. Van Hoorst, p. I-LII +1-214.

Bowsher, A. L. 1955. Origin and adaptation of platyceratids gastropods. Mollusca, University of Kansas Paleontological Contributions, Article 5, p. 1-11 
BretT, C.E. and Walker, S.E. 2002. Predators and predation in Paleozoic marine environments: In Kowalewski, M. and Kelly, P. H. (eds.), The fossil record of predation. Paleontological Society Papers, 8:93-118.

Brenkle, P.L., Lane, H.R., Heckel, P.H., and Rankey, E.C. 2005. Description of field trip stops: In Startigraphy and Biostratigraphy of the Mississippian Subsystem (Carboniferous System) in its type region, the Mississippi River Valley of Illinois, Missouri, and Iowa, I.U.G.S. Subcommission on Carboniferous, Guidebook for Field Conference, September 813, 2001, $107 \mathrm{p}$.

Broadhead, T.W. 1981. Carboniferous camerate crinoid subfamily, Dichocrininae. Palaeontographica, Abt. A, 176:81-157.

Broadiead, T.W. 1985. Evolution of Carboniferous Hexacrinitacea (Criniodea, Camerata): Neuvième Congrès International de Stratigraphie et de Géologie du Carbonifère (1979), Compte Rendu, 5:205-215.

Broadhead, T.W. and Strimple, H.L. 1980. Hyrtanecrinus, a new Carboniferous camerate crinoid genus from eastern North America. Journal of Paleontology, 54:35-44.

Burdick, D.W. and Strimple, H.L. 1983. Genevievian and Chesterian crinoids of Alabama. Geological Survey of Alabama, Bulletin (1982), 121:1-277.

Butts, C. 1941. Geology of the Appalachian Valley in Virginia. Part II, Fossil Plates and Explanations. Virginia Geological Survey, Bulletin, 52:1-271.

Carney, C. and Smosna, R. 1989. Carbonate deposition in a shallow marine gulf, the Mississippian Greenbrier Limestone of the central Appalachian Basin. Southeastern Geology, 30:25-48.

Carr, D.C., Rexroad, C.B., and Gray, H.H. 1986. Compendium of Paleozoic Rock-Unit 
Stratigraphy in Indiana- A Revision, Department of Natural Resources. Geological Survey Bulletin 59, p. 128-130.

Chestnut, D.R., and EtTensohn, F.R. 1988. Hombergian (Chesterian) echinoderm Paleontology and paleoecology, south-central Kentucky. Bulletins of American Paleontology, 95:1-102.

Collinson, C., Norby, R.D., Thompson, T.L., and Baxter, J.W. 1979. Stratigraphy of the Mississippian stratotype-upper Mississippi Valley. U.S.A. Guidebook, Field Trip 8, Ninth International Congress of Carboniferous Stratigraphy and Geology, Illinois State Geological Survey, 109 p.

Collinson, C., Sargent, M.L.and Jennings, J.R. 1988. Illinois Basin Region, Sedimentary Cover-North American Craton: U.S., L. L. Sloss (ed.), The Geology of North America, v.D-2, The Geological Society of America, p. 383-426.

Conkin, J.E., and Conkin, B.M. 1976. Guide to the rocks and fossils of Jefferson County, Kentucky, southern Indiana, and adjacent areas, second and revised edition. University of Kentucky Publication, 239 p.

Copper, P. 1994. Ancient reef ecosystem expansion and collapse. Coral Reefs, 13:3-12.

COPPER, P. 2002. Silurian and Devonian reefs: 80 million years of global greenhouse between two ice ages: In Kiessling, W., Flügel, E., and Golonka, J. (eds.), Panerozoic Reef Patterns: Society of Economic Paleontologists and Mineralogists Special Publication 72, p. 181-238. Cummings, E.R. 1901. The use of Bedford as a formational name. Journal of Geology, 9:232-233. 
DoDD, J.R. 1987. Introduction to the Valmeyeran carbonate rocks of Southern Indiana: In Dodd, J. R. (Ed.), Valmeyeran (Middle Mississippian) carbonate rocks of Southern Indiana, A Guidebook for Annual Field Trip of the Great Lakes Section Society of Economic Paleontology and Mineralogy, p.3-31.

Dodd, J.R., Hunter, R.E., and Merkley, P.A. 2001. Eolinite-Bearing Deposition Cycles in the Ste. Genevieve Limestone of Indiana and Kentucky: Evidence for Mississippian Eustasy, Modern and Ancient Carbonate Eolianites: Sedimentology, Sequence Stratigraphy, and Diagensis, SEPM Special Publication No. 71, p.151-166.

Droste, J.B. and Carpenter, G.L. 1990. Subsurface stratigraphy of the Blue River Group (Mississippian) in Indiana. Department of Natural Resources, Geological Survey Bulletin $62,45 \mathrm{p}$

EHRENBERG, K. 1922. Über verschiedene Lösungen zweier mechanischer Probleme in Crinoidenstielen. Paläontologische Zeitschrift, 5:95-96.

Ehrenberg, K. 1926. Zur Frage der Rekonstruktion von Camptocrinus indoaustralicus Wanner. Paläontologische Zeitschrift, 7:250-260.

Ehrenberg, K. 1930. Die "Nebenformen" der Crinoiden, ihre stammesgeschichliche Entwicklung und Bedeutung: Palaeobiologica, 3:257-324.

EldRedGe, N. 1979. Alternative approaches to evolutionary theory. Bulletin of the Carnegie Museum of Natural History, 13:7-19.

ELrod, M.N. 1899. The geological relations of some St. Louis group caves and sinkholes. Indiana Academy of Science Proceedings for 1898, p. 258-267.

Engelmann, G. 1847. Remarks on the St. Louis Limestone. American Journal of Science, 3:119-120. 
Erwin, D.H. 2006. Extinction: How life on Earth nearly ended 250 million years ago. Princeton University Press, Princeton, New Jersey, 320 p.

FeARnHEAD, F.E. 2008. Towards a systematic standard approach to describing fossil crinoids, illustrated by the redescription of a Scottish Silurian Pisocrinus de Koninck, Scripta Geologica, 136:39-61.

Feldman, H.R. 1989. Echinoderms of the Somerset Shale Member, Salem Limestone (Mississippian), in Indiana and Kentucky. Journal of Paleontology, 63:900-912.

Feldman, H.R., Brown, M.A. and Archer, A.W. 1993. Benthic assemblages as indicators of sediment stability; evidence from grainstones of the Harrodsburg and Salem Limestones (Mississippian, Indiana): In Keith, B.D. and Zuppann, C.W. (eds.), AAPG Studies in Geology 35:115-128.

Gahn, F.J. and Baumiller, T.K. 2005. Arm regeneration in Mississippian crinoids; evidence of intense predation pressure in the Paleozoic? Paleobiology, 31:151-164.

Gahn, F.J. and Kammer, T.W. 2002. The Cladid Crinoid Barycrinus from the Burlington Limestone (Early Osagean) and the Phylogenetics of Mississippian Botryocrinids. Journal of Paleontology, vol:123-133.

GoRBY, S.S. 1886. Geology of Washington County: Indiana Department of Geology and Natural History Annual Report 15, p. 117-153.

Grabau, A. W. and Shimer, H. W. 1910. North American index fossils, invertebrates: New York, 2: 1-909. (Echinoderms, p. 458-603).

Guensburg, T. E. and Sprinkle, J., 2001. Earliest crinoids: New evidence for the origin of the dominant Paleozoic echinoderms, Geology, 29:131-134.

Guensburg, T. E. and Sprinkle, J., 2003. The oldest known crinoids (early Ordovician, Utah) 
And a new crinoid plate homology system. Bulletins of American Paleontology. Number 364, 43 p.

Guensburg, T. E. and SprinkLe, J., 2009. Solving the mystery of crinoid ancestry: new fossil evidence of arm origin and development, Journal of Paleontology, 83:350-364.

HaLl, J. 1858. Chapter 8. Palaeontology of Iowa: In Hall, J. and Whitney, J.D.(eds.), Report of the Geological Survey of the state of Iowa: Embracing the results of investigations made during portions of the years $1855,56 \&$ : 57, v. 1, part II; Palaeontology, p. 473-724, 29 pl., index to Part II separately paginated, 3 p.

HaLl, J. 1859. Contributions to the palaeontology of Iowa, being descriptions of new species of Crinoidea and other fossils. Supplement to vol. I, part II, of the Geological Report of Iowa, 1-92.

HALL, J. 1860. Contributions to the palaeontology of Iowa: being descriptions of new species of Crinoidea and other fossils. Iowa Geological Survey, supplement to 1(2) of Geological Report of Iowa, 1859a, 4 p.

HaLL, J. 1861. Descriptions of new species of Crinoidea; from investigations of the Iowa Geological Survey. Preliminary notice: Albany, New York; C. van Benthuysen, 18 p. HALL, J. and WhitNEY, J.D. 1858. Report on the geological survey of the State of Iowa, embracing the results of investigations made during 1855, 56, 57. Geology, 1:473-724.

Hattin, D.E. 1958. Regeneration in a Pennsylvanian crinoids spine. Journal of Paleontology, $32: 701-702$.

HatTin, D.E. and DodD, J.R. 1992. Mississippian paleosols, paleokarst, and eolian carbonates in Indiana, Field Trip Guide for Annual Meeting of the Geological Society of America, October 26-29, 1992, p. 10-30. 
Hess, H., Ausich, W.I., Brett, C.E., Simms, M.J. 1999. Fossil Crinoids. Cambridge University Press, Cambridge, United Kingdom (GBR), 275 p.

HinZe, W.J. and BraiLe, L.W. 1988. Geophysical aspects of the Craton: US, Sedimentary

Cover-North American Craton: U.S. In L. L. Sloss (ed.), The Geology of North America, v. D-2. The Geological Society of America, p. 5-24.

JAekel, O. 1918. Phylogenie und System der Pelmatozoen: Paläeontologische Zeitschrift, 31-128. (Often referred to as 1921 but actually published October, 1918 and not reprinted 1921.)

Kammer, T.W. 1984. Crinoids from the New Providence Shale Member of the Borden Formation (Mississippian) in Kentucky and Indiana. Journal of Paleontology, 58:115-130.

Kammer, T.W. 1985. Aerosol filtration theory applied to Mississippian Deltaic crinoids. Journal of Paleontology, 59:551-560.

Kammer, T.W. and Ausich, W.I. 1987. Aerosol suspension feeding and current velocities: distributional controls for late Osagean crinoids. Paleobiology, 13:379-395.

Kammer, T.W. and Ausich, W.I. 1992. Advanced cladid crinoids from the Middle Mississippian of the east-central United States; primitive-grade calyces. Journal of Paleontology, 6:461-480.

Kammer, T.W. and Ausich, W.I. 1993. Advanced cladid crinoids from the Middle Mississippian of the east-central United States: Intermediate-grade calyces. Journal of Paleontology, 67:614-639.

Kammer, T.W. and Ausich, W.I. 1994. Advanced cladid crinoids from the Middle Mississippian of the east-central United States; advanced-grade calyces. Journal of Paleontology, 68:339-351. 
Kammer, T. W. and Ausich. W.I. 1996. Primitive cladid crinoids from upper Osagean-lower Meramecian (Mississippian) rocks of east-central United States. Journal of Paleontology, 70:835-866.

Kammer, T.W. and Ausich, W.I. 2006. The "Age of Crinoids"; a Mississippian biodiversity spike coincident with widespread carbonate ramps. PALAIOS, 21:238-248.

Kammer, T.W. and Ausich, W.I. 2007a. Soft-tissue preservation of the hind gut in a new genus of cladid crinoids from the Mississippian (Visean, Asbian) at St. Andrews, Scotland. Palaeontology, 50:951-959.

Kammer, T.W. and Ausich, W.I. 2007b. Stratigraphical and geographical distribution of Mississippian (Lower Carboniferous) Crinoidea from Scotland. Earth and Environmental Science Transactions of the Royal Society of Edinburgh, 98:139-150.

Kammer, T.W. Ausich, W.I. and Goldstein, A. 2007. Gilmocrinus kentuckyensis n. sp. From The Late Osagean (Mississippian) Muldraugh Member of the Borden Formation in Kentucky: A European immigrant originally derived from North America? Journal of Paleontology, 81:209- 121.

Kammer, T.W., T.K. Baumiller, and Ausich, W.I. 1998. Evolutionary significance of differential species longevity in Osagean-Meramecian (Mississippian) crinoid clades. Paleobiology, 24:155-176.

Kammer, T.W., T.K. Baumiller, and Ausich, W.I. 1997. Species longevity as a function of niche breadth: Evidence from fossil crinoids. Geology, 25:219-222.

Kammer, T.W., Brenckle, P.L., Carter, J.L., and Ausich, W.I. 1990. Redefinition of the Osagean-Meramecian Boundary in the Mississippian Stratotype Region. Palaios, 5:414431. 
Kammer, T.W. and Cox, K.D. 1985. Paleoecology of a delta slope community from the

Lower Mississippian Borden Formation in Central Kentucky. Southeastern Geology, 26: 39-46.

Kammer, T.K. and Springer, G.S. 2008. Biostratigraphy of crinoids from the Wymps Gap Member of the Greenbrier Formation (Mississippian, Chesterian) in northern West Virginia. Journal of Paleontology, 82:1182-1189.

Kearey, P., Klepeis, K. A. and Vine, F. J. 2009. Global Tectonics, $3^{\text {rd }}$ edition, Wiley Blackwell, Hoboken, N.J. p.370-378.

Keith, B.D. and Thompson, T.A. 2005. Detailed Map Unit Descriptions for Monroe and Lawrence Counties, Provided by personal communication. p. 5.

Keyes, C.R. 1894. Paleontology of Missouri, part I. Missouri Geological Survey, 4:143225.

KeroHeR, G.C. 1966. Lexicon of geological names of the United States for 1936-1960. Geological Survey Bulletin 1200, Part 3, P-Z, p. 3396-3406.

Khetani, A.B. and Read, J.F. 2002. Sequence development of a mixed carbonate-siliciclastic high-relief ramp, Mississippian, Kentucky, U.S.A. Journal of Sedimentary Research, 72:657- 672 .

KIRK, E. 1940. Seven new genera of Carboniferous Crinoidea Inadunata. Journal of the Washington Academy of Science, 30:321-334.

KIRK, E. 1941a. Dinotocrinus, a new fossil inadunate crinoid genus: Proceedings of the U.S. National Museum, 89:513-518.

KIRK, E. 1941b. Four new genera of Mississippian Crinoidea Inadunata: Journal of Paleontology, 15:81-88. 
KIRK, E. 1944a. Cribanocrinus, a new rhodocrinoid genus: Journal of the Washington Academy of Science, 34:13-16.

KIRK, E. 1944b. Aphelecrinus, a new inadunate crinoid genus from the Upper Mississippian: American Journal of Science, 242:190-203.

KIRK, E. 1944c. Cymbiocrinus, a new inadunate crinoid genus from the Upper of Mississippian: American Journal of Science, 242:233-245.

Lane, H.R. and Brenckle, P.L. 2005. Type Mississippian subdivisions and biostratigraphic succession, In Heckel, P.H. (ed.), Stratigraphy and Biostratigraphy of the Mississippian Subsystem (Carboniferous System) in its Type Region, the Mississippi River Valley of Illinois, Missouri, and Iowa: Illinois State Geological Survey, Guidebook 34, p. 76-105.

Lane, N.G. 1958. The Monobathrid Camerate Crinoid Family: Batocrinidae, Unpublished Ph.D. dissertation, University of Kansas, Lawrence, 259 p.

Lane, N.G. 1963. Two new Mississippian camerate (Batocrinidae) crinoid genera. Journal of Paleontology, 37:691-702.

Lane, N.G. 1971. Crinoids and reefs. Proceedings of the North American Paleontological Convention, part J, p. 1430-1443.

Lane, N.G. 1972. Synecology of Middle Mississippian (Carboniferous) crinoid communities in Indiana, , $24^{\text {th }}$ IGC, Section 7, p. 89-94.

LaNE, N.G. 1984. Predation and survival among Inadunate crinoids. Paleobiology, 10:453-458.

Lane, H.R. and Brenckie, P.L. 2005. Type Mississippian subdivisions and biostratigraphic succession, In Heckel, P. H. (ed.), Stratigraphy and Biostratigraphy of the Mississippian Subsystem (Carboniferous System) in its Type Region, the Mississippi River Valley of 
Illinois, Missouri, and Iowa: Illinois State Geological Survey, Guidebook 34, p. 76-105.

Lasemi, Z., Norby, R.D. 1999. Stratigraphy, Paleoenvironments, and Sequence Stratigraphy Implications of the Middle Mississippian Carbonates in Western Illinois, Middle Mississippian Carbonates and Siliciclastics in Western Illinois. Illinois State Geological Survey, ISGS Guidebook 31, p. 1-18.

Lasemi, Z., Norby, R.D., Devera, J.A., Fouke, B.W., Leetaru, H.E. and Denny, F.B. 1999. Middle Mississippian carbonates and siliciclastics in Western Illinois. Illinois State Geological Survey, ISGS Guidebook 31.

Laudon, L.R. 1957. Crinoids. In Treatise on marine ecology and paleoecology. Ed.

Ladd. H. S. Geologic Society of America, Memoir 67, 2:961-971.

LAUDON, L.R. 1973. Stratigraphic crinoid zonation in Iowa Mississippian rocks: Proceedings of the Iowa Academy of Science, 80:25-33.

Lewis, D.N. and Donovan, S.K. 2007. A standardized method of describing fossils. Scripta Geologica., 134:109-188.

LinebACK, J.A. 1972. Lateral gradation of the Salem and St. Louis Limestones (Middle Mississippian) in Illinois. Illinois State Geological Survey, Circular 474, p. 1-21.

Lyon, S.S. and Casseday, S.A. 1860. Description of nine new species of Crinoidea from the Subcarboniferous rocks of Indiana and Kentucky. American Journal of Science and Arts, ser. 2, 29:68-79.

Maisey, J. G. 1996. Discovering fossil fishes. A Henry Holt Reference Book. Henry Holt and Company, New York.223 p.

Malott, C.A. 1932. Lost River at Wesley Chapel Gulf, Orange County, Indiana. Indiana Academy of Science Proceedings for 1931, 41:285-316. 
Maples, C.G. and Waters, J.A. 1987. Redefinition of the Meramecian/Chesterian boundary (Mississippian). Geology, 15:647-651.

Martorana, A. 1987. Subsurface carbonate deposition in the Sanders and Blue River Groups (Valmeyeran) in the Eastern Illinois Basin. In J. Robert Dodd (ed.), Valmeyeran (Middle Mississippian) Carbonate Rocks of Southern Indiana, p.21-33.

McGregor, D. J. 1954. Gypsum and anhydrite deposits in southwestern Indiana. Geological Survey, Indiana Department of Conservation, Report of Progress No. 8, 26 p.

Meek, F.B. and Worthen, A.H. 1860. Descriptions of new species of Crinoidea and Echinoidea from the Carboniferous rocks of Illinois, and other western states. Proceedings of the Academy of Natural Sciences of Philadelphia, 12:379-397.

Meek, F.B. and Worthen, A.H. 1865. Descriptions of new crinoidea, etc. from the Carboniferous rocks of Illinois and some of the adjoining states. Proceedings of the Academy of Natural Sciences of Philadelphia, 17:155-166.

Meek, F.B. and Worthen, A.H. 1868. Palaeontology of Illinois. Illinois Geological Survey, $3: 289-565$.

Meek, F.B. and Worthen, A.H. 1870. Descriptions of new species and genera of fossils from Paleozoic rocks of the western states. Proceedings of the Academy of Natural Sciences of Philadelphia, 22:22-56.

Meek, F.B. and Worthen, A.H. 1873. Palaeontology, Descriptions of invertebrates from Carboniferous System. Illinois Geological Survey, 5:323-619, pl. 1-32. Meglitsch, P. A. 1967. Invertebrate Zoology: Oxford University Press, New York, 961 p. 
Meyer, D.L. and Ausich, W.I. 1983. Biotic interactions among recent and among fossil crinoids, Chapter 9. In Tavesz, M.J.S., and McCall, P. L.(eds.), Biotic interactions in recent and fossil benthic communities: Plenum Publishing Corp., p. 337-427.

Meyer, H. von. 1858. Crinoideen aus dem Posidonomyen-Schiefer Deutschlands: Neues Jahrbuch für Mineralogie, Geologie und Paläontologie, 1858, p. 59-62. (nonsystematic). MilLER, J.S. 1821. A natural history of the Crinoidea, or lily-shaped animals; with observations on the genera, Asteria, Euryale, Comatula and Marsupites: Bristol, England, Bryan \& Co., 150 p.

MilLeR, S.A. 1889. North American geology and paleontology: Cincinnati, Western Methodist Book Concern, $664 \mathrm{p}$.

MilLeR, S.A. 1897. Second appendix to North American geology and palaeontology, p. 719-793. (See Miller, S.A., 1889)

Miller, S.A. and Gurley, W.F.E. 1896. New species of crinoids from Illinois and other states.

Illinois State Museum, Bulletin 9, p. 1-66.

Moore, M.C. 1976. Survey Drill Hole 265, Harris Stone Service, Putnam County, Indiana. p. 13.

Moore, R.C. 1933. Historical Geology: McGraw-Hill, New York, 673 p.

Moore, R.C., Jeffords, R.M., and Miller, T.H. 1968. Collecting localities, references and index: University of Kansas Paleontological Contributions, Supplement of Echinodermta Articles 8-10, p. 1-18.

Moore, R.C. and Laudon, L.R. 1943. Evolution and classification of Paleozoic crinoids, Geological Society of America Special Papers, No. 46, p. 153. 
Moore, R.C. and Laudon, L.R. 1944. Class Crinoidea. In Shimer, H.W. and Shrock, R.R.(eds.), Index fossils of North America: John Wiley and Sons, Inc., New York, p. 137-209.

Morris, J. 1843. A catalogue of British fossils. Comprising all the genera and species hitherto described; with reference to their geological distribution and to the localities in which they have been found, 1st ed.: London, John Van Voorst, 222 p. (nonsystematic)

PhILLIPS, J. 1836. Illustrations of the geology of Yorkshire, or a description of the strata and organic remains, Part 2, The Mountain Limestone districts, $2^{\text {nd }}$ edition. John Murray, London: 203-208.

Priest, A. 1970. Fossil collecting in the Pella beds of Iowa. Earth Science, 23: 13-16.

Qi, L., Carr, T.R. and Goldstein, R.H. 2007. Geostatistical three-dimensional modeling of oolite shoals, St. Louis Limestone, southwest Kansas. American Association of Petroleum Geologists Bulletin, 91:69-96.

Rexroad, C.B. 1986. Compendium of Paleozoic Rock-Unit Stratigraphy in Indiana: A Revision, Department of Natural Resources. Geological Survey Bulletin 59, p. 132-133. Rexroad, C.B. 2000. The St. Louis/Ste. Genevieve (Mississippian) boundary problem in Indiana and the Conodont Biostratigraphy, Addendum to Guidebook for Field Trip \#1, North-CentralSection Geological Society of America, in Stratigraphy and Commercial Quality of the St. Louis Limestone (Mississippian) by James Nowacki, 10 p. Rexroad, C.B. and Collinson, C. 1963. Conodonts from the St. Louis Formation (Valmeyeran Series) of Illinois, Indiana, and Missouri. Illinois State Geological Survey, Circular 355, p.1- 28. 
Ross, C. A. and Ross, J.R. 1988. Late Paleozoic transgressive-regressive deposition. In Wilgus, C. K., Hastings, B. S., Kendall, C. G. St. C., Posamentier, H. W., Ross, C. A. and Van Wagoner, J. C., eds., Sea-level changes: an intergrated approach. SEPM, Special Publication, 42:227-247.

Rowley, R.R. 1901-04. Description of fossils. In Green, G.K.(ed.), Contribution to Indiana Palaeontology: New Albany, Indiana, v. 1, no. 7, p. 50-60, pl. 19-21 (1901a); no. 8, p. 6274, pl. 22-24 (1901b); no. 10, p. 85-97, pl. 28-30 (1902a); no. 11, p. 98-109, pl. 31-33 (1903a); no.12, p. 110-129, pl. 34-36 (1903b); no. 13, p. 130-137, pl. 37-39 (1903c); no. 14, p. 138-145, pl. 40-42 (1903d); no. 15, p. 146-155, pl. $43-45$ (1903e); no. 16, p. 156167, pl. 46-48 (1903f); no. 17, p. 168-175, pl. 49-51 (1904a); no. 18, p. 176-184, pl. $52-54$ (1904b); no. 19, p. 185-197, pl. 55-57 (1904c).

Schmidt, H. 1929. Tierische Leitfossilien des Karbon. In Gürich, G. (ed.), Leitfossilien: Berlin, Gebrüder Borntraeger, pt. 6, p. 1-107.

Sepkoski, J.J. 1984. A kinetic model of Phanerozoic taxonomic diversity, III: Post-Paleozoic families and mass extinctions. Paleobiology, 10:246-267.

Shaver, R.H., Ault, C.H., Burger, A.M., Carr, D.D., Droste, J.B., Eggert, D.L., Gray, H.H., Harper, D., Hasenmuller, N.R., Hasenmuller, W.A., Horowitz, A.S., Hutchison, H.C., Keith, B. D., Keller, S.J., Patton, J.B., Rexroad, C.B., Wier, C.E. 1986. Compendium of Paleozoic rock-unit stratigraphy in Indiana: A revision. Indiana Geological Survey Bulletin 59, $203 \mathrm{p}$.

Shumard, B.F. 1855. Description of new species of organic remains. Missouri Geological Survey, 2:185-208. 
Shumard, B.F. 1858. Description of new fossil Crinoidea from the Palaeozoic rocks of the western and southern portions of the United States. Transactions of the St. Louis Academy of Science (1857), 1:71-80.

Shumard, B.F. 1860. Observations on the geology of the county of Ste. Genevieve. St. Louis Academy of Science Transactions, 1:406.

Shumard, B.F. 1865-1866. Catalogue of Palaeozoic fossils, Part 1, Echinodermata: Transactions of the St. Louis Academy Science, 2:334-394 (1865); p. 395-407 (1866).

Shumard, B.F. 1868. A catalogue of the Palaeozoic fossils of North America: Part I.

Paleozoic Echinodermata. Transactions of the St. Louis Academy of Science (1866), 2:334-407. (Separate of Shumard, 1865-1866.)

Siebenthal, C. E. 1897. General geographical and stratigraphical features. In T.C. Hopkins, and C.E.Siebenthal (eds.), The Bedford oolitic limestone. In Blatchley, W. S. Indiana Department of Geology and Natural Resources Annual Report 21, p. 291-325.

Signor, P.W. and Brett, C.E. 1984. The mid-Paleozoic precursor to the Mesozoic marine revolution. Paleobiology, 10:229-245.

Simms, M. J. 1999. Systematics, Phylogeny and Evolutionary History, P. 31, In H. Hess, W.I. Ausich, C.E. Brett, M.J. Simms (eds.) Fossil Crinoids, Cambridge University Press, Cambridge, United Kingdom (GBR).

SLoss, L. L. 1988. Tectonic Evolution of the Craton in Phanerozoic Time, Sedimentary Cover-North American Craton:U.S., P. 25-51, In: L. L. Sloss, Editor, The Geology of North America, v.D-2, The Geological Society of America. 
Smith, L. B. and Read, J. F. 1999. Application of high-resolution sequence stratigraphy to tidally influenced Upper Mississippian Carbonates, Illinois Basin, p.107126, In P.M. Harris, A.H. Saller, J.A. Simo (eds.), Advances in Carbonate Sequence Stratigraphy, Applications to Reservoirs, Outcrops and Models, SEPM Special Publication No. 63.

Smith, N.M., Sunderman, J.A. and Melhorn, W.N. 1961. Breccia and Pennsylvanian cave filling in Mississippian St. Louis Limestone, Putnam County, Indiana. Journal of Sedimentary Petrology, 31:275-287.

SpRINGER, F. 1906. Discovery of the disk of Onychocrinus and further remarks on the Crinoidea Flexibilia. Journal of Geology, 14:467-523.

Springer, F. 1913. Crinoidea. In Zittel, K. A. von, Text book of paleontology (translated and edited by C. R. Eastman). 2nd edit.: London, Macmillan \& Co., Ltd., 1:173-243.

Springer, F. 1920. The Crinoidea Flexibilia. Smithsonian Institution Publication 2501, 1:1486. Springer, F. 1926. Unusual forms of fossil crinoids. Proceedings of the U.S. National Museum, 67:1-137.

Sprinkle J. and Coluins, D. 1995. Echmatocrinus revisited: Still an echinoderm and probably the earliest crinoid. Geological Society of America, Abstracts with Programs, 27:A113.

Sprinkle, J., Guensburg, T. E. and Gahn, F. J. 2008. Overview of early Ordovician crinoid diversity from the Western and Southwestern United States. In W. I. Ausich and G. D. Webster (eds.) Echinoderm Paleobiology, Indiana University Press, Bloomington.

Strimple, H.L. 1961. Morrowan Hydriocrinus. Oklahoma Geology Notes, 21:306-307. Strimple, H.L. 1967. Aphelecrinidae, a new family of inadunate crinoids. Oklahoma Geology Notes, 27:81-85. 
Strimple, H.L. and Horowitz, A.S. 1971. A new Mississippian ampelocrinid. In Fossil Crinoid Studies: University of Kansas Paleontological Contributions, Paper 56, no. 5, p. 23-27.

StRimple, H.L. and Watkins, W.T. 1969. Carboniferous crinoids of Texas with stratigraphic implications. Palaeontographica Americana, 6:139-275.

Swallow, G.C. 1855. Second Annual Report. Missouri Geological Survey First and Second Annual Reports, p. 25-207.

Swann, D.H. 1963. Classification of the Genevievian and Chesterian (Late Mississippian) rocks of Illinois. Illinois State Geological Survey RI 216, 91 p.

Treworgy, J.D. 1990. Kaskaskia Sequence: Mississippian Valmeyeran and Chesterian Series, In M.W. Leighton, D.R. Kolata, D.F. Oltz, J.J. James (eds.), AAPG Memoir, 51:125-142. Treworgy, J.D. and Devera, J.A. 1990. Kaskaskia Sequence overview; Middle Devonian Series through Chesterian Series, p.109-112. In M. W. Leighton, D. R. Kolata, D. F. Oltz, J. J. James (eds.), AAPG Memoir, v. 51.

Troost, G., 1850. A list of the fossil crinoids of Tennessee. American Association for the Advancement of Science, Proceedings (1849), Series. 2, 8:59-64. (nonsystematic, but names cited by later workers)

Ubaghs, G. 1953. Classe des Crinoides. In Piveteau, J.(ed.), Traité de paléontologie: Paris, Masson \& Cie, 3:658-773.

Ubaghs, G. 1978a. Evolution of Camerate Crinoids, p. T281-292. In R.C. Moore and C. Teichert, (eds.), Treatise on Invertebrate Paleontology, Part T, Echinodermata 2(1). Geological Society of America and University of Kansas Press, Lawrence. 
Ubaghs, G. 1978b. Camerata, p. T410-519. In R.C. Moore and C. Teichert, (eds.), Treatise on Invertebrate Paleontology, Part T, Echinodermata 2(2). Geological Society of America and University of Kansas Press, Lawrence.

Ulrich, E.O. 1904. Preliminary notes on classification and nomenclature of certain Paleozoic rock units in eastern Missouri. In Buckley, E. R., and Buehler, H. A. (eds.), The quarrying industry of Missouri. Missouri Bureau of Geology and Mines, 2:109-111.

UlRich, E.O. 1917. The formations of the Chester Series in Western Kentucky and their correlation elsewhere. Kentucky Geological Survey, p. 1-236.

Val Valen, L.M. 1973. A new evolutionary law. Evolutionary Theory, 1:1-30.

Vermeis, G.J. 1977. The Mesozoic marine evolution: Evidence for snails, predators and grazers.Paleobiology, 3:245-258.

Wachsmuth, C. and Springer, F. 1880-1886. Revision of the Palaeocrinoidea: Proceedings of the Academy of Natural Sciences of Philadelphia Pt. I. The families Ichthyocrinidae and Cyathocrinidae (1880), p. 226-378, pl. 15-17 (separate repaged p. 153, pl. 1-3). Pt. II. Family Sphaeroidocrinidae, with the sub-families Platycrinidae, Rhodocrinidae, and Actinocrinidae (1881), p. 177-411, pl. 17-19 (separate repaged, p. 1237, pl. 17-19). Pt. III, Sec. 1. Discussion of the classification and relations of the brachiate crinoids, and conclusion of the generic descriptions (1885), p. 225-364, pl. 4-9 (separate repaged, 1-138, pl. 4-9). Pt. III, Sec. 2. Discussion of the classification and relations of the brachiate crinoids, and conclusion of the generic descriptions (1886), p. 64-226 (separate repaged to continue with section 1, 139-302).

Wachsmuth, C. and Springer, F. 1897. The North American Crinoidea Camerata: Harvard College of Comparative Zoology, Memoir 20, 21, 897 p. 
Waters, J.A., Lane, N. G..,Maples, C.G., and Webster, G.D. 2001. Post-extinction echinoderms in the Late Devonian world; Implications for evolution and biogeography, earth systems processes; programmes with abstracts, Geological Society of America and Geological Society of London, International (III)

Waters, J.A., Maples, C.G., Lane, N.G., Marcus, S., Liao, Z. T., Liu, L., Hou, H. F., and WANG, J. X., 2003. A quadrupling of Famennian pelmatozoan richness: new Late Devonian blastoids and crinoids from northwest China: Journal of Paleontology, 77:922-948

Webster, G.D. 1973. Bibliography and index of Paleozoic crinoids, 1942-1968. Geological Society of America, Memoir 137, p. 1-341.

WeBster, G.D. 1977. Bibliography and index of Paleozoic crinoids, 1969-1973. Geological Society of America, Microform Publication 8, p. 1-235, 3 cards.

Webster, G.D. 1986. Bibliography and index of Paleozoic crinoids, 1974-1980. Geological Society of America, Microform Publication 16, p. 1-405, 5 cards.

WeBster, G.D. 1988. Bibliography and index of Paleozoic crinoids and coronate echinoderms 1981-1985. Geological Society of America, Microform Publication 18, p. 1235,3 cards.

Webster, G.D. 1993. Bibliography and index of Paleozoic crinoids, 1986-1990. Geological Society of America, Microform Publication 25, p. 1-204, 3 cards. (nonsystematic) WebsTeR, G.D. 2003. Bibliography and Index of Paleozoic crinoids, coronates, and hemistreptocrinoids, 1758-1999: Geological Society of America, Special Paper 363 (online) http://crinoid.gsajournals.org/crinoidmod.

Weller, J.M. 1917. The Mississippian fauna of Kentucky. In The Paleontology of Kentucky. 
Kentucky Geological Survey, Series 6, 36:249-292.

Weller, S. 1898. A bibliographic index of Carboniferous invertebrates. U. S. Geological Survey, Bulletin 153, p. 1-653.

Weller, S. 1920. The Geology of Hardin County. Chapt. 13, Paleontology: Illinois Geological Survey, Bulletin, 41:313-377.

Wilmarth, M.G., Compiler, 1938. Lexicon of Geologic Names of the United States (Including Alaska), United States Department of the Interior. Geological Survey, Bulletin 896, pp. 2396.

Wood, E. 1909. A critical summary of Troost's unpublished manuscript on the crinoids of Tennessee: U.S. National Museum, Bulletin, 64:1-150.

Woodson, F.J. 1981. Uppermost St. Louis Limestone (Mississippian): the Horse Cave Member in Indiana. Proceedings of the Indiana Academy of Science, 91:419-427.

Worthen, A.H. 1875. In Worthen, A. H. and Meek, F. B. 1875. Palaeontology of Illinois. Section II. Description of invertebrates. Geology and palaeontology: Illinois Geological Survey, 6:489-532.

Worthen, A.H. 1882. Descriptions of fifty-four new species of crinoids from the Lower Carboniferous limestones and Coal Measures of Illinois and Iowa: Illinois State Museum of Natural History, Bulletin, 1:3-38.

Worthen, A.H. 1883. Description of fossil invertebrates: Illinois Geological Survey, 7:269322, pl. 27-30.

Zittel, K.A. von. 1895. Grundzüge der Palaeontologie (Palaeozoologie), 1st edit, 971 p., R. Oldenbourg, München. (see Wachsmuth, 1895, for crinoids) 


\section{Appendices}

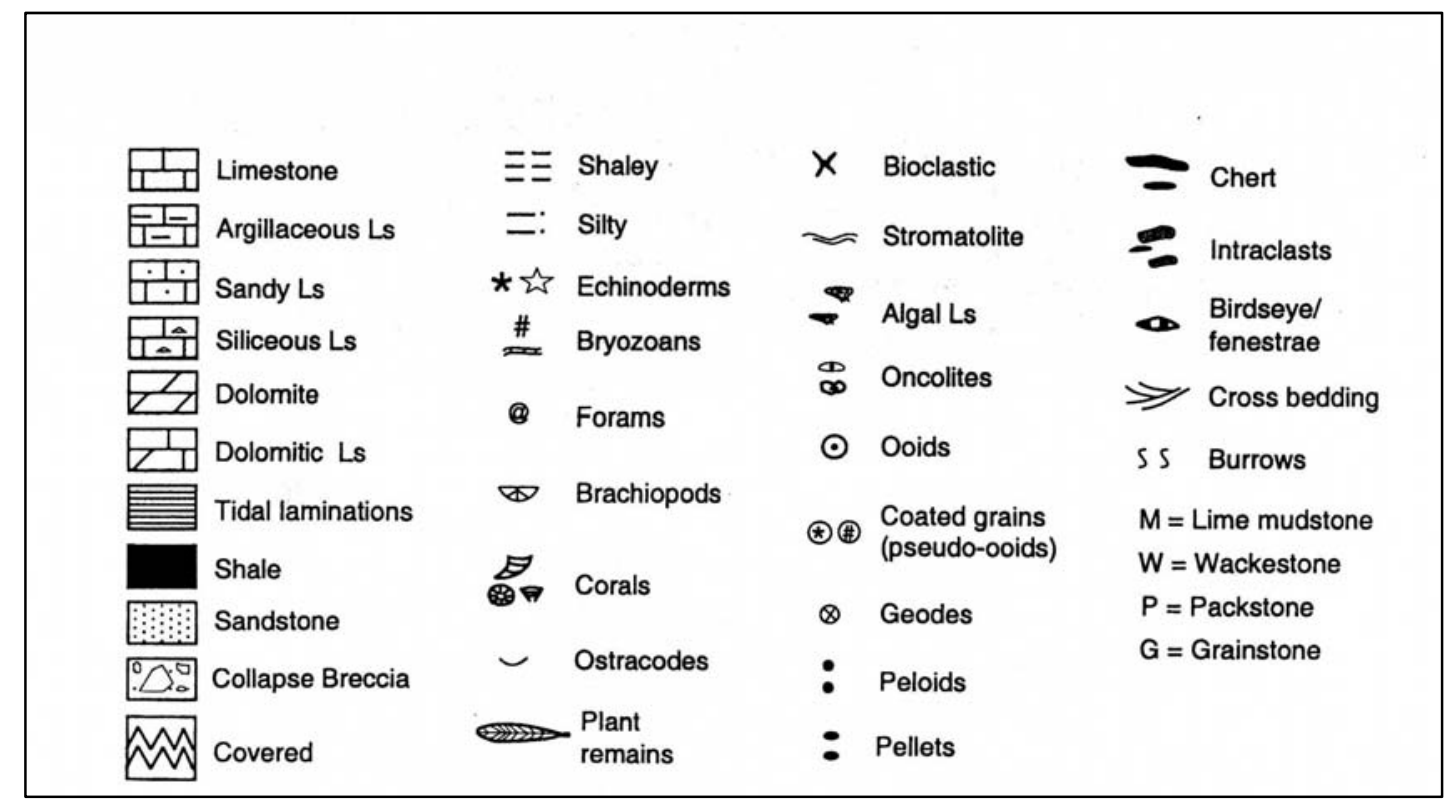

Appendix A. Key for figures 5, 7, and 11, of Geologic Setting section, and Appendix B. 


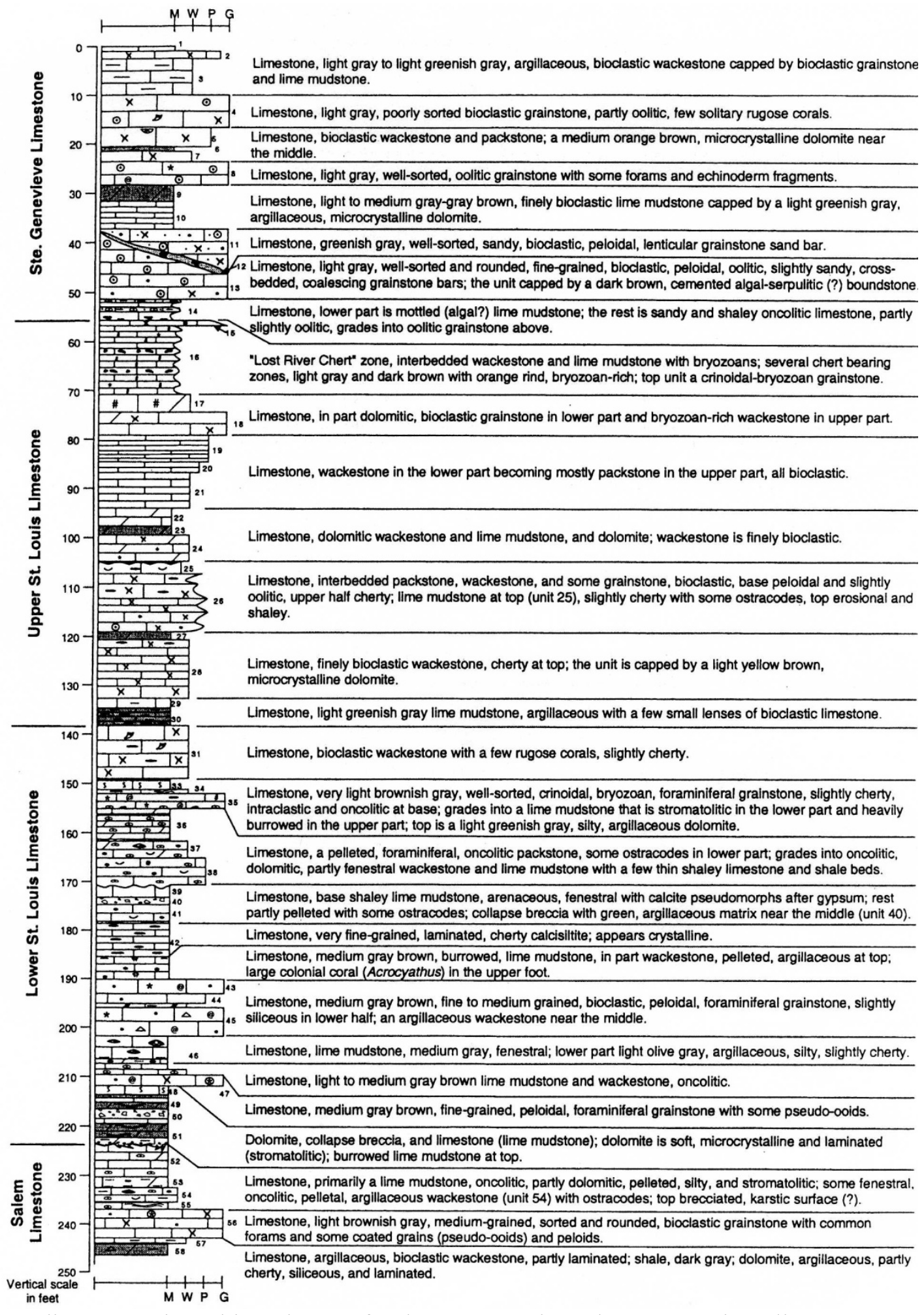

Appendix B. Stratigraphic column of Salem, St. Louis and Ste Genevieve limestones at

the Casper Stolle Quarry just southwest of St. Louis Missouri and south of Alton, Illinois, on the western edge of the Illinois Basin (Lasemi, et al., 1999). See Appendix A for key. 


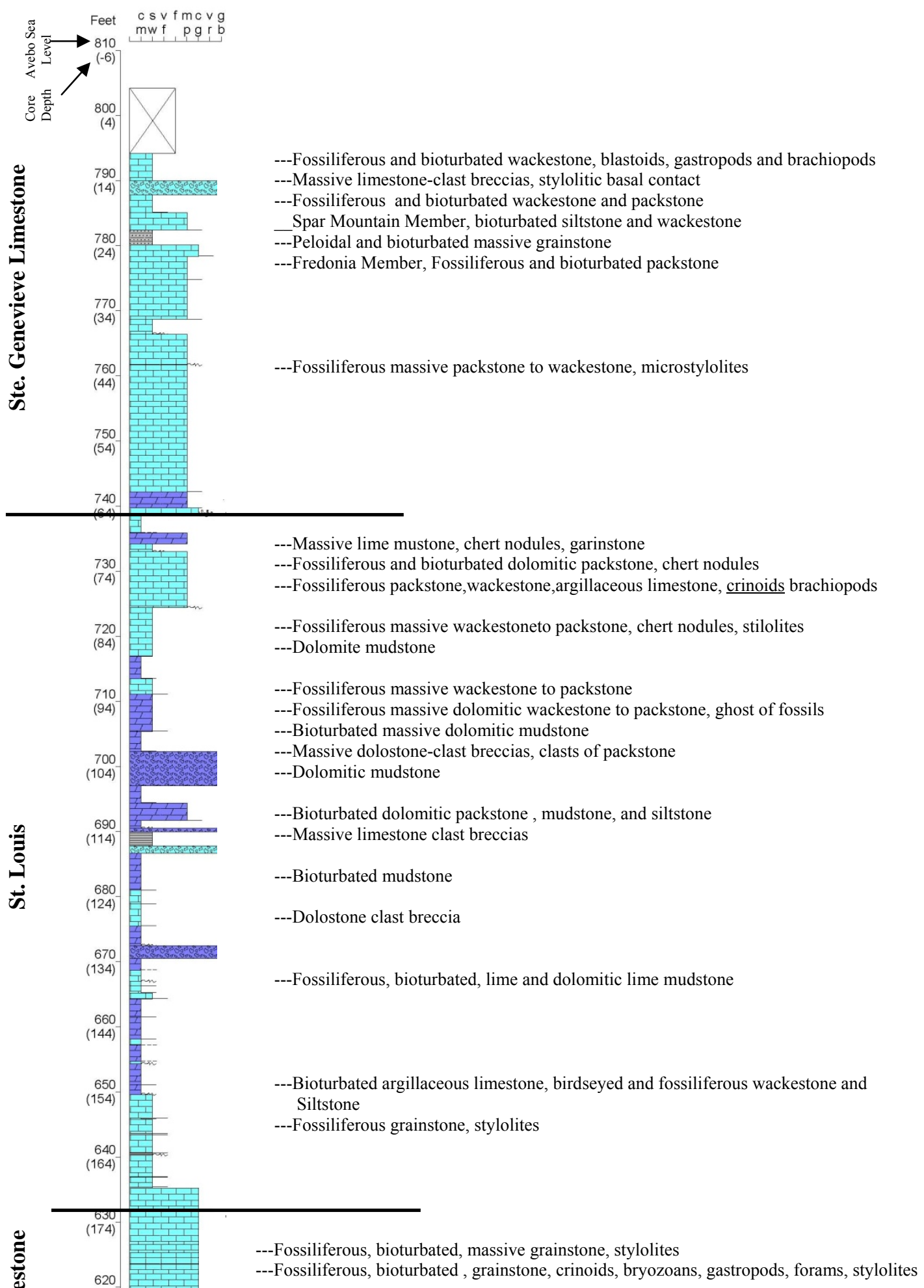

Appendix C. Stratigraphic column of the salem, St. Louis and Ste. Genevieve limestones, Owen County, Indiana, eastern edge of the Illinois Basin. Just south of Bainbridge, Indiana (Adapted from Keith and Thompson, 2005). 


\begin{tabular}{|c|c|c|c|c|c|}
\hline \multicolumn{2}{|c|}{ Indiana State } & \multirow[b]{2}{*}{ Taxon } & \multirow[b]{2}{*}{$\begin{array}{l}\text { Museum } \\
\#\end{array}$} & \multirow[b]{2}{*}{ Museum Label } & \multirow[b]{2}{*}{ Taxon } \\
\hline Museum \# & Museum Label & & & & \\
\hline 71.1 .9425 & Crinoid w Trilobite & Culmicrinus missouriensis & 71.1 .9487 & ? Aphelecrinus & Aphelecrinus scoparius \\
\hline 71.1 .9426 & Crinoid & Pachylocrinus & 71.1 .9488 & & Aphelecrinus scoparius \\
\hline 71.1 .9427 & & Poss Aphelecrinus scoparius & 71.1 .9490 & & Dinotocrinus salteri \\
\hline 71.1 .9428 & & Phacelocrinus dactyliformis & 71.1.9491 & ? Cymbiocrinus & Dinotocrinus salteri \\
\hline 71.1 .9429 & Flex. & Poss. Barycrinus & 71.1 .9492 & Crinoid, ? Cymbio. & Stinocrinus ? Sp. \\
\hline 71.1 .9430 & Crinoid & Phacelocrinus dactyliformis & 71.1.9493 & & Dinotocrinus salteri \\
\hline 71.1 .9431 & & C.miss./P.vanhornei /P.dactyl. & 71.1 .9494 & & Camptocrinus \\
\hline 71.1 .9432 & & ? Phacelocrinus & 71.1 .9499 & & Culmicrinus missouriensis \\
\hline 71.1 .9433 & Crinoid & Taxocrinus shumardianus & 71.1 .9500 & & Platycrinites \\
\hline 71.1 .9434 & & Prob. Cymbiocrinus dactylus & 71.1.9501 & ? Scytalocrinus & Phacelocrinus dactyliformis \\
\hline 71.1 .9437 & & Phacelocrinus & 71.1 .9502 & & Not IDable \\
\hline 71.1 .9438 & & ? Platycrinites & 71.1 .9503 & & Not IDable \\
\hline 71.1 .9439 & & ?Phacelocrinus dactyliformis & 71.1 .9504 & & ?Phacelocrinus dactyliformis \\
\hline 71.1 .9441 & & Platycrinites niotensis/pumilus & 71.1 .9505 & ? Pachylocrinus & ?Cymbio.dactylus/Pachylocr \\
\hline 71.1 .9443 & Crinoid & Stinocrinus ? sp. & 71.1 .9506 & ? Histocrinus & Phacelocrinus dactyliformis \\
\hline 71.1 .9444 & Crinoid & Platycrinites niotensis & 71.1 .9507 & & Not IDable \\
\hline 71.1 .9445 & ? Histocrinus & Cribanocrinus coxanus & 71.1 .9508 & Crinoid & Pachylocrinus norwoodi? \\
\hline 71.1 .9446 & & ?Taxocrinus shumardianus & 71.1 .9509 & & Phacelocrinus dactyliformis \\
\hline 71.1 .9448 & Criniod & Poss Cymbiocrinus dactylus & 71.1 .9510 & & Poss Cymbiocrinus dactylus \\
\hline 71.1.9449 & Crinoid & Phacelocrinus & 71.1 .9511 & ? Scytalocrinus & Not IDable \\
\hline 71.1 .9451 & Flex.-? Taxo. & Taxocrinus shumardianus & 71.1 .9512 & & Not IDable \\
\hline 71.1 .9452 & Flex.-? Taxo. & Taxocrinus shumardianus & 71.1 .9513 & & ?Platycrinites \\
\hline 71.1 .9453 & Flex.- ? Taxo. & Taxocrinus shumardianus & 71.1 .9514 & & Not IDable \\
\hline 71.1 .9454 & Flex.-? Taxo. & Taxocrinus shumardianus & 71.1 .9516 & & ?Phacelocrinus dactyliform \\
\hline 71.1 .9455 & Flex & Taxocrinus shumardianus & 71.1 .9518 & & Culmicrinus missouriensis \\
\hline 71.1 .9456 & C. missouriensis & Culmicrinus missouriensis & 71.1 .9519 & ? Scytalocrinus & Armenocrinus howelli \\
\hline 71.1 .9457 & C. missouriensis & Culmicrinus missouriensis & 71.1 .9520 & & Armenocrinus howelli \\
\hline 71.1 .9458 & C. missouriensis & Culmicrinus missouriensis & 71.1 .9521 & ? Scytalocrinus & Armenocrinus howelli \\
\hline 71.1.9459 & & Culmicrinus missouriensis & 71.1 .9522 & ? Scytalocrinus & Phacelocrinus dactyliformis \\
\hline 71.1.9462 & C. missouriensis & Culmicrinus missouriensis & 71.1 .9523 & & Not IDable \\
\hline 71.1 .9463 & & Culmicrinus missouriensis & 71.1 .9524 & ? Pachylocrinus & Stinocrinus? Sp. \\
\hline 71.1 .9464 & & Culmicrinus missouriensis & 71.1 .9525 & Crinoid & ?Dinotocrinus salteri \\
\hline 71.1 .9467 & Flex. -? Onycho & Taxocrinus shumardianus & 71.1 .9526 & ? Scytalocrinus/Histocri & Armenocrinus howelli \\
\hline 71.1 .9468 & & Taxocrinus shumardianus & 71.1 .9527 & Crinoid & Pachylocrinus norwoodi? \\
\hline 71.1 .9469 & Flex.-?Onycho & Taxocrinus shumardianus & 71.1 .9528 & & ?Armenocrinus howelli \\
\hline 71.1 .9470 & Flex.- ? Onycho. & Taxocrinus shumardianus & 71.1 .9529 & & Platycrinites ?niotensis \\
\hline 71.1 .9471 & & Taxocrinus shumardianus & 71.1 .9533 & & Culmicrinus missouriensis \\
\hline 71.1 .9482 & & Stem & & & \\
\hline
\end{tabular}

\title{
Appendix D. Indiana State Museum Crinoid Collection from Harris Stone Quarry,
}

\author{
Bainbridge, Indiana.
}




\begin{tabular}{|c|c|c|c|c|c|}
\hline Spec. \# & Name & Spec. \# & Name & Spec. \# & Name \\
\hline 1-1-1 & Pachylocrinus & $2-6-5$ & Phacelocrinus dactylus. & $3-7-2$ & Taxocrinus shumandianus \\
\hline $1-2-1$ & Pachylocrinus & $2-6-6$ & Phacelocrinus dactylus. & $3-7-3$ & \\
\hline $1-2-2$ & Pachylocrinus & $2-6-7$ & Armenocrinus howelli & 3-8-1 & Taxocrinus shumandianus \\
\hline $1-2-3$ & Pachylocrinus & $2-7-1$ & Culmicrinus missouriensis & $3-8-2$ & Taxocrinus shumandianus \\
\hline $1-2-4$ & Pachylocrinus & $2-7-2$ & Culmicrinus missouriensis & $3-9-1$ & Taxocrinus shumandianus \\
\hline $1-3-1$ & Pachylocrinus nodobasalis & $2-8-1$ & Culmicrinus missouriensis & $3-9-2$ & Taxocrinus shumandianus \\
\hline $1-3-2$ & Pachylocrinus nodobasalis & $2-8-2$ & Phacelocrinus dactylus. & $3-9-3$ & Taxocrinus shumandianus \\
\hline $1-3-3$ & Pachylocrinus nodobasalis & $2-8-3$ & Armenocrinus howelli & $3-9-4$ & Platycrinites sarae \\
\hline $1-3-4$ & Pachylocrinus nodobasalis & $2-8-4$ & Culmicrinus missouriensis & $3-10-1$ & Taxocrinus shumandianus \\
\hline $1-4-1$ & Not Identifiable & $2-8-5$ & Culmicrinus missouriensis & $3-10-2$ & Taxocrinus shumandianus \\
\hline $1-4-2$ & Lanecrinus fountainensis & $2-8-6$ & Culmicrinus missouriensis & $3-10-3$ & Taxocrinus shumandianus \\
\hline $1-4-3$ & ?Cymbiocrinus dactylus & 2-9-1 & Culmicrinus missouriensis & $3-10-4$ & Taxocrinus shumandianus \\
\hline $2-1-1$ & Culmicrinus missouriensis & $2-9-2$ & ? Phacelocrinus & 3-11-1 & Taxocrinus shumandianus \\
\hline $2-1-2$ & Culmicrinus missouriensis & $2-9-3$ & ?Phacelocrinus vanhornei & $3-11-2$ & Taxocrinus shumandianus \\
\hline $2-2-1$ & Culmicrinus missouriensis & $2-10-1$ & Culmicrinus missouriensis & $3-11-3$ & Taxocrinus shumandianus \\
\hline $2-3-1$ & Culmicrinus missouriensis & $2-10-2$ & ?Phacelocrinus vanhornei & $3-11-4$ & Taxocrinus shumandianus \\
\hline $2-3-2$ & Culmicrinus missouriensis & $2-10-3$ & & $3-11-5$ & Taxocrinus shumandianus \\
\hline $2-3-3$ & Culmicrinus missouriensis & $2-10-4$ & Culmicrinus missouriensis & $3-11-6$ & Taxocrinus shumandianus \\
\hline $2-3-4$ & Culmicrinus missouriensis & $2-10-5$ & Culmicrinus missouriensis & $3-11-7$ & Taxocrinus shumandianus \\
\hline $2-3-5$ & Culmicrinus missouriensis & $2-11-1$ & Culmicrinus missouriensis & 4-1-1 & Taxocrinus shumandianus \\
\hline $2-4-1$ & Culmicrinus missouriensis & $2-11-2$ & Culmicrinus missouriensis & $4-2-1$ & ?2 Cymbiocrinus \\
\hline $2-4-2$ & ?Platycrinites niotensis & $2-11-3$ & Culmicrinus missouriensis & $4-2-2$ & ?Cymbiocrinus \\
\hline $2-4-3$ & ?Platycrinites niotensis & $3-1-1$ & & $4-2-3$ & \\
\hline $2-4-4$ & ?Taxocrinus shumardianus & $3-1-2$ & Taxocrinus shumardianus & $4-2-4$ & Culmicrinus or /Phacelocrinus \\
\hline $2-4-5$ & 2Platycrinites, 1 Cymbiocrinus & $3-1-3$ & 1Platycrinites.2T.shumardianus & 4-3-1 & \\
\hline $2-5-1$ & Culmicrinus missouriensis & $3-2-1$ & Camptocrinus cirrifer & $4-3-2$ & Pentaramicrinus altonensis \\
\hline $2-5-2$ & Culmicrinus missouriensis & 3-3-1 & Cymbiocrinus dactylus & 4-3-3 & ?Decadocrinus \\
\hline $2-5-3$ & Culmicrinus missouriensis & 3-4-1 & & $4-3-4$ & \\
\hline $2-5-4$ & Culmicrinus missouriensis & 3-5-1 & Onychocrinus & $4-3-5$ & Amphelecrinus peculiaris \\
\hline $2-6-1$ & Phacelocrinus & 3-6-1 & Cymbiocrinus grandis? & $4-3-6$ & Phacelocrinus vanhornei \\
\hline $2-6-2$ & Phacelocrinus & $3-6-2$ & Cymbiocrinus grandis? & $4-4-1$ & Pentaramicrinus altonensis \\
\hline $2-6-3$ & Armenocrinus howelli & $3-6-3$ & Cymbiocrinus grandis? & $4-4-2$ & Pentaramicrinus altonensis \\
\hline $2-6-4$ & Phacelocrinus & $3-7-1$ & Onychocrinus magnus & $4-4-3$ & Hyrtanecrinus ornatus \\
\hline
\end{tabular}

Appendix E. Uncataloged material in the stratigraphic collection, United States National

Museum, Springer Collection. No numbers are provided with the specimens within the

Springer Collection. Specimen numbers here are those supplied by this author for

organizational purposes and do not appear on specimens within the Springer Collection. 


\begin{tabular}{|c|c|c|c|c|c|}
\hline Spec.\# & Name & Spec. \# & Name & Spec. \# & Name \\
\hline $4-5-1$ & Eratocrinus & $5-6-2$ & Phacelocrinus vanhornei & $5-18-4$ & Platycrinites \\
\hline $4-6-1$ & Phacelocrinus vanhornei & $5-7-1$ & Cymbiocrinus dactylus & $5-18-5$ & Platycrinites niotensis \\
\hline $4-7-1$ & Platycrinites niotensis & $5-8-1$ & Platycrinites sarae & $5-18-6$ & Platycrinites sarae \\
\hline $4-7-2$ & Platycrinites niotensis & $5-8-2$ & Phacelocrinus vanhornei & $5-18-7$ & Platycrinites niotensis \\
\hline $4-7-3$ & Platycrinites niotensis & $5-9-1$ & Phacelocrinus vanhornei & $5-18-8$ & Platycrinites \\
\hline $4-8-1$ & Culmicrinus missouriensis & $5-10-1$ & Phacelocrinus vanhornei & $5-18-9$ & Platycrinites sarae \\
\hline $4-8-2$ & P.niotensis, P.vanhornei & $5-10-2$ & Pachylocrinus spinobraciatus & $5-18-10$ & Platycrinites niotensis \\
\hline 4-8-3 & Phacelocrinus.or C.missouriensis & $5-10-3$ & Pachylocrinus spinobraciatus & $5-18-11$ & Platycrinites niotensis \\
\hline 4-8-4 & Phacelocrinus.or C.missouriensis & $5-10-4$ & Pachylocrinus spinobraciatus & $5-18-12$ & Platycrinites sarae \\
\hline $4-8-5$ & Phacelocrinus vanhornei & $5-10-5$ & Pachylocrinus spinobraciatus & $5-18-13$ & Platycrinites niotensis \\
\hline 4-9-1 & Platycrinites niotensis & $5-10-5 b$ & Pachylocrinus spinobraciatus & $5-19-1$ & Phacelocrinus vanhornei \\
\hline $4-9-2$ & Platycrinites niotensis & $5-10-6 a$ & Pachylocrinus spinobraciatus & $5-19-2$ & Phacelocrinus vanhornei \\
\hline $4-10-1$ & Aphelecrinus scoparius & $5-10-6 b$ & Pachylocrinus spinobraciatus & $5-19-3$ & Phacelocrinus vanhornei \\
\hline $4-10-2$ & & $5-10-6 c$ & ?Culmicrinus or Phacelocrinus & $5-19-4$ & Phacelocrinus vanhornei \\
\hline $4-10-3$ & Culmicrinus missouriensis & $5-11-1$ & Platycrinites pumilus & $5-19-5$ & Phacelocrinus vanhornei \\
\hline $4-10-4$ & & $5-11-2$ & Platycrinites sarae & $5-19-6$ & Phacelocrinus vanhornei \\
\hline $4-10-5$ & Culmicrinus missouriensis & $5-11-3$ & Platycrinites niotensis & $5-19-7$ & Phacelocrinus vanhornei \\
\hline $4-10-6$ & Culmicrinus missouriensis & $5-11-4$ & Platycrinites pumilus & $5-19-8$ & Phacelocrinus vanhornei \\
\hline $4-10-7$ & Culmicrinus missouriensis & $5-11-5$ & Platycrinites pumilus & $5-19-9$ & Phacelocrinus vanhornei \\
\hline $4-10-8$ & Culmicrinus missouriensis & $5-12-1$ & Cymbiocrinus grandis & $5-19-10$ & Phacelocrinus vanhornei \\
\hline $5-1-1$ & Phacelocrinus vanhornei & $5-13-1$ & Platycrinites niotensis & $5-19-11$ & Phacelocrinus vanhornei \\
\hline $5-2-1$ & Culmicrinus missouriensis & $5-14-1$ & Pachylocrinus nodobasalis & $5-19-12$ & \\
\hline 5-3-1 & Culmicrinus missouriensis & $5-15-1$ & & $5-19-13$ & Phacelocrinus vanhornei \\
\hline $5-3-2$ & Culmicrinus missouriensis & $5-16-1$ & Platycrinites pumilus & $5-19-14$ & Phacelocrinus vanhornei \\
\hline $5-3-3$ & Culmicrinus missouriensis & $5-16-2$ & Platycrinites pumilus & $5-20-1$ & Cymbiocrinus \\
\hline $5-3-4$ & Culmicrinus missouriensis & $5-16-3$ & Platycrinites sarae & $5-20-2$ & Cymbiocrinus \\
\hline $5-3-5$ & Culmicrinus missouriensis & $5-17-1$ & Platycrinites niotensis & $5-20-3$ & Cymbiocrinus \\
\hline $5-3-6$ & Culmicrinus missouriensis & $5-17-2$ & Platycrinites & $5-20-4$ & Cymbiocrinus grandis \\
\hline $5-3-7$ & Culmicrinus missouriensis & $5-17-3$ & Platycrinites niotensis & $5-20-5$ & Cymbiocrinus \\
\hline $5-3-8$ & Culmicrinus missouriensis & $5-17-4$ & Platycrinites sarae & $5-20-6$ & Cymbiocrinus \\
\hline $5-4-1$ & Phacelocrinus dactyliformis & $5-18-1$ & Platycrinites niotensis & $5-20-7$ & Cymbiocrinus \\
\hline $5-5-1$ & Platycrinites sarae & $5-18-2$ & Platycrinites niotensis & & \\
\hline $5-6-1$ & Scytalocrinus robustus & $5-18-3$ & Platycrinites sarae & & \\
\hline
\end{tabular}

Appendix E. Continued. 


\begin{tabular}{|c|c|c|c|c|c|}
\hline $\begin{array}{l}\text { Museum } \\
\text { ID } \\
\text { Number }\end{array}$ & $\begin{array}{c}\text { Museum Label } \\
\text { Genus }\end{array}$ & Updated Genus & Updated Species & Source & Formation \\
\hline 6602 & Poteriocrinus & Phacelocrinus & vanhornei & Alton & St. Louis \\
\hline 7999 & Pachylocrinus & Culmicrinus & missouriensis & Alton & St. Louis \\
\hline 9435 & Scaphiocrinus & Dinotocrinus & compactus & Monroe, Co & Ste Gen. \\
\hline 9436 & Scaphiocrinus & Phacelocrinus & dactyliformis & Monroe, Co & St. Louis \\
\hline 9436 & & Phacelocrinus & dactyliformis & & \\
\hline 9436 & & Aphelecrinus & scoparius & & \\
\hline 9437 & Scaphiocrinus & Abrotocrinus & sculptus & Monroe, Co & Ste Gen. \\
\hline 9438 & Scaphiocrinus & Dinotocrinus & huntsvillae & Monroe, Co & Ste Gen. \\
\hline 9440 & Scytalocrinus & Pachylocrinus & nodobasalis & Monroe, Co & St. Louis \\
\hline 9440 & & Pachylocrinus & nodobasalis & & \\
\hline 9440 & & Pachylocrinus & nodobasalis & & \\
\hline 9441 & Scytalocrinus & Aphelecrinus & scoparius & Monroe, Co & St. Louis \\
\hline 9450 & Scaphiocrinus & Dinotocrinus & compactus & Alton & St. Louis \\
\hline 9451 & Scytalocrinus & Culmicrinus & missouriensis & Alton & St. Louis \\
\hline 9452 & Scytalocrinus & Phacelocrinus & longidactylus & Alton & Ste Gen. \\
\hline 9453 & Scytalocrinus & Dinotocrinus & huntsvillae & Alton & Ste Gen. \\
\hline 9453 & & Dinotocrinus & huntsvillae & & \\
\hline 9454 & Scytalocrinus & Scytalocrinus & robustus & Alton & Ste Gen. \\
\hline 9456 & Scaphiocrinus & Abrotocrinus & sculptus & St. Louis & Ste Gen. \\
\hline 9458 & Scytalocrinus & Abrotocrinus & sculptus & Hardin Co & Ste Gen. \\
\hline 9458 & & Abrotocrinus & sculptus & & \\
\hline 9459 & Scaphiocrinus & Dinotocrinus & compactus & Hardin Co & Ste Gen. \\
\hline 9460 & Scaphiocrinus & Phacelocrinus & vanhornei & Hardin Co & Ste Gen. \\
\hline 9858 & Scytalocrinus & Phacelocrinus & vanhornei & Alton & St. Louis \\
\hline 10135 & Scytalocrinus & Lanecrinus & fountainensis & St. Louis & Chesterian \\
\hline 10135 & & Lanecrinus & fountainensis & & \\
\hline 10135 & & Lanecrinus & fountainensis & & \\
\hline 10135 & & Lanecrinus & fountainensis & & \\
\hline 10135 & & Lanecrinus & fountainensis & & \\
\hline 10135 & & Lanecrinus & fountainensis & & \\
\hline 10136 & Scaphiocrinus & Phacelocrinus(Poteriocrinus) & vanhornei(arrectarius) & St. Louis & St. Louis \\
\hline 10136 & & Phacelocrinus(Poteriocrinus) & vanhornei(arrectarius) & & \\
\hline 10931 & Scytalocrinus & Cymbiocrinus & dactylus & Alton & St. Louis \\
\hline 10932 & Scytalocrinus & Phacelocrinus & vanhornei & Alton & St. Louis \\
\hline 10932 & & Phacelocrinus & vanhornei & & \\
\hline 10933 & Scytalocrinus & Phacelocrinus & vanhornei & Alton & St. Louis \\
\hline 10933 & & Phacelocrinus & vanhornei & & \\
\hline 10934 & Scaphiocrinus & Culmicrinus & missouriensis & Alton & St. Louis \\
\hline 10934 & & Culmicrinus & missouriensis & & \\
\hline 10934 & & Culmicrinus & missouriensis & & \\
\hline 10934 & & Culmicrinus & missouriensis & & \\
\hline 10934 & & Culmicrinus & missouriensis & & \\
\hline 12990 & Scytalocrinus & Phacelocrinus & vanhornei & Carond. Mo. & St. Louis \\
\hline 12990 & & Phacelocrinus & vanhornei & & \\
\hline 12990 & & Phacelocrinus & vanhornei & & \\
\hline 12990 & & Phacelocrinus & vanhornei & & \\
\hline 12990 & & Phacelocrinus & vanhornei & & \\
\hline 12990 & & Phacelocrinus & vanhornei & & \\
\hline 12990 & & Phacelocrinus & vanhornei & & \\
\hline 13101 & Scytalocrinus & Phacelocrinus & dactyliformis & Carond. Mo. & St. Louis \\
\hline 19121 & Scytalocrinus & Cymbiocrinus & dactylus & Hardin Co & St. Louis \\
\hline
\end{tabular}

Appendix F. Crinoids from the Field Museum of Natural History, Chicago, Illinois. 


\section{LEWIS ANDERSON COOK}

Route 3 Box 4-A

846 West Maple Avenue

Fayetteville, WV, 25840

\section{Vita}

\section{Education}

PhD, Geology, Paleontology, West Virginia University

$1997-1998$

Master of Science, Anthropology, University College London, London, England

$1973-1976$

University

University, Richmond, Virginia

1973 Doctor of Medicine, West Virginia University, Morgantown, West Virginia

1968 Bachelor of Arts, West Virginia University, Morgantown, West Virginia

\section{Positions Held}

1990 -- 2010 Clinical Assistant Professor, West Virginia University School of Medicine

2001 -- 2006 Board of Directors, West Virginia Medical Institute (President of the Board-05-06)

2000 -- 2006 Physician, Family Practice, Fayetteville, West Virginia

1976 -- 1997 Physician, Family Practice, Fayetteville, West Virginia

1985, 1991 Chief of Staff, Raleigh General Hospital, Beckley, West Virginia

1988

1984--1997 (Intermittently) Chairman, Department of Family Practice, Raleigh

General Hospital, Beckley, West Virginia

1980--1986 West Virginia Medical Institute, Consultant and Reviewer.

1973 -1976 Family Practice Residency, Medical College of Virginia, Virginia Commonwealth University, Richmond, Virginia

$1962-1965$ United States Army, Medical Corps

\section{Dissertation and Thesis}

Ph.D.- Systematics and Evolutionary Paleoecologyof Crinoids from the St. Louis Limestone (Mississippian, Meramecian) of the Illinois Basin

Master's Thesis - How many Species at Pasalar? A Study in Molar Morphology

\section{Presentations}

1. Cook, L. A. and Kammer, T. W. 2009. Systematic revision of crinoids from the St. Louis Limestone (Meramecian, Illinois Basin). Abstracts with Programs, Geological Society of America, vol. 41, No.7, p.452.

2. Cook L. A. and Kammer, T. W. 2008. Changes in Mississippian Crinoid Diversity during deposition of the St. Louis Limestone (Meramecian) in the Illinois Basin, Abstracts with Programs, Geological Society of America, 40:140.

3. Gill, M. K., Simon, D. J., Rhenberg, E. C., Cook, L. A., Ausich, W. I., and Kammer, T. W. 2008. Crinoid Biodiversity in the Lower Mississippian Lake Valley Formation. Abstracts with Programs, Geological Society of America, 40:140.

4. Rhenberg, E. C., Simon, D. J., Cook, L. A., Gill, M. K., Ausich, W. I., and Kammer, T. W. 2008. Comparison of Early Mississippian Crinoid Generic Diversity Patterns Between the Lake Valley Formation of New Mexico and the Burlington Limestone of Iowa. Abstracts with Programs, Geological Society of America, 40:141

\section{Honors}

Golden Key International Honour Society, Mountain, West Virginia University

Fellow, American Academy of Family Practice, Sigma Gamma Epsilon, West VirginiaUniversity 